\title{
Microbial loop dynamics in Antarctic sea-ice
}

\section{Andrew Robert Martin}

\author{
A thesis \\ submitted to Victoria University of Wellington \\ in fulfilment of the requirement for the degree of \\ Doctor of Philosophy \\ in Ecology \& Biodiversity
}

Victoria University of Wellington

Te Whare Wānanga o te Ūpoko o te Ika a Māui

2009 


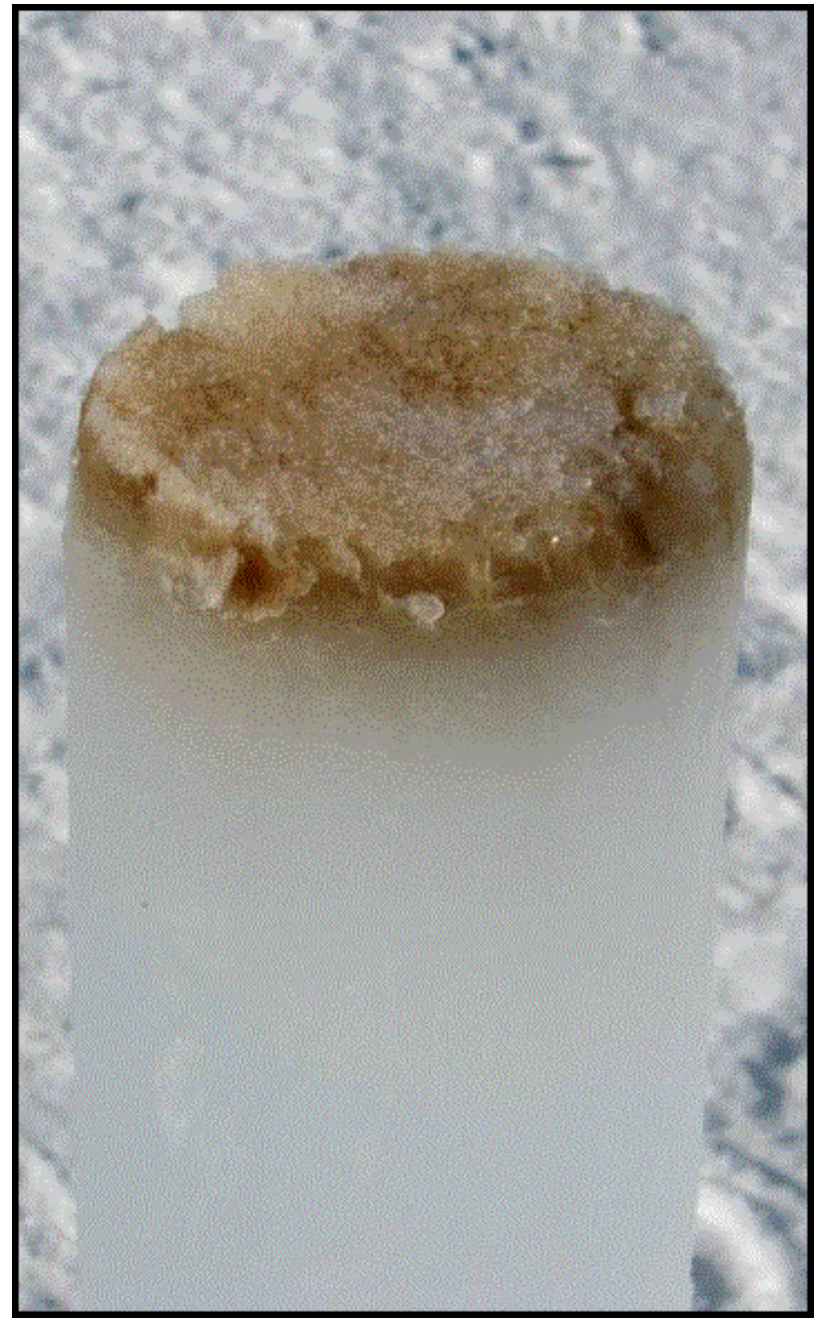

I presume that the numerous lower pelagic animals persist on the infusoria, which are known to abound in the open ocean: but on what, in the clear blue water, do these infusoria subsist?

Charles Darwin 
We shall not cease from exploration And the end of all our exploring Will be to arrive where we started And know the place for the first time.

Through the unknown, unremembered gate

When the last of earth left to discover Is that which was the beginning; At the source of the longest river The voice of the hidden waterfall And the children in the apple-tree Not known, because not looked for But heard, half-heard, in the stillness Between two waves of the sea. Quick now, here, now, alwaysA condition of complete simplicity (Costing not less than everything) And all shall be well and All manner of thing shall be well When the tongues of flame are in-folded Into the crowned knot of fire And the fire and the rose are one.

T.S. Eliot 


\begin{abstract}
Sea-ice is a predominant feature of polar oceans and exerts a unique influence on marine ecosystems. The annual circumpolar expansion of sea-ice around Antarctica provides a stable platform for the in situ colonisation and growth of a diverse assemblage of microbes that are integral to the energy base of the Southern Ocean. An active microbial loop has been proposed to operate within the ice matrix connecting bacteria, microalgae and protozoa, but validating this metabolic pathway has historically relied on bulk correlations of chlorophyll $a$ (a surrogate for microalgal biomass) and estimates of bacterial production or abundance. I investigate the microbial loop using a range of physiological, genetic, and ecological techniques to determine whether the photosynthate exuded by phototrophic microalgae serves as a growth substrate for heterotrophic bacteria. This link is examined at a range of spatial (in vitro and in situ experiments) and temporal ( 8 hours to 18 days) scales by manipulating the supply of algal-derived photosynthate and documenting the subsequent change in bacterial metabolic activity, cell abundance and community composition.
\end{abstract}

Single-cell analysis of both bacterial membrane integrity and intracellular activity revealed that sea ice is among the most productive microbial habitats. In short-term in vitro experiments, increased availability of dissolved organic matter (DOM) was shown to elicit a rapid metabolic response in sea ice bacteria, however single-activity was significantly reduced in treatments where photosynthate was restricted by either removing the majority of algal cells or inhibiting photosynthesis with 3-(3,4dichlorophenyl)-1,1-dimethylurea (DCMU). To verify this metabolic response, microcosm simulations were conducted over a period of 9 days with microbes 
derived from two regions of the ice (bottom layer and high-salinity surface region) with presumed differences in the concentration of DOM. Metabolic activity was relatively low in bacteria derived from the high-saline region of the ice and in cultures spiked with DCMU, photosynthate limitation restricted bacterial growth and significantly influenced community structure. In contrast, the bottom of the ice is characterised by a high concentration of DOM and bacterial metabolic activity was shown to be higher and DCMU was less influential with respect to changes in bacterial abundance or community composition. To examine in situ microbial dynamics, a series of cores were extracted from Antarctic sea-ice and reinserted into the ice matrix upside down to expose resident microbial assemblages to a significantly different light, temperature and salinity regime. Limited assimilation of algal-derived DOM by bacteria in ice cores that were flipped illustrated a malfunction in the microbial loop after a period of 18 days. Bacteria originally at the bottom of the sea ice appeared to be temperature-limited, while a lack of growth in cells originally at the top of the ice profile was attributed to a community dominated by slow-growing psychrophilic species. A stronger physiological response to disturbance was elicited by microalgae and significant growth was contrasted with severe bleaching and cell death. This reciprocal transplant is the first of its kind to examine the in situ sea ice community and illustrats that although microbial assemblages are similar with respect to trophic dynamics, they are also attuned to distinct regions within the ice. The bacterial assimilation of algal-derived DOM is of fundamental importance to the microbial loop and by confirming that photosynthate is a major stimulus for bacterial growth, these results provide a new and unique insight into microbial dynamics in Antarctic sea-ice. 


\section{Acknowledgements}

\section{While at times the PhD journey is long and lonely, the help and support of many people and organisations has always been at hand - I am grateful to them all.}

I would first like to thank my supervisors, Ken Ryan and Julie Hall. Ken, I am extremely grateful for the guidance and support you have given me all these years. Your encouragement and enthusiasm has been limitless and so often was what kept me going. I thank you for inspiring me both professionally, and personally...it has been a privilege to be your student. Julie, thank you for the time and energy you have put into my research, quite simply, you have always been able to give exactly the right advice at the right time!

Office colleagues, fellow students and friends have been there through it all - the anchor of my sanity! Thanks to you all, especially Alex Dixson, Barnaby Dixson, Joe Buchanan, Kevin Crume, Thomas Gaitanos, Chris Gibbons, Paul Johnstone, Hayley Middleton, Dr David Hiddlestone-Naith, Julian Thompson and Kristen Westfall.

For quality times during the 'downtime' on the ice (brief as it always was), I thank Ed Abdool, Ranjeet Bhagooli, Lisa Bryant, Simon Davy, Stuart Donachie, Mike Hudson Eileen Koh, Libby Liggins, Blake McDavitt, Andrew McMinn, Daniel 'Snout' McNaughtan, Craig Marshall, Ronan O’Toole, Meghanna Rajanahally, Melianie Raymond, Mary Sewell, Lavinia Suberg, Helen Thompson and Schannel 'Goose' van Dijken.

The technical and administrative support in SBS has been fantastic, my sincere thanks to Delwyn Carter-Jarratt, Jo Davy, Craig Doney, Neville Higgison, Alan Hoverd, Cameron Jack, Paul Marsden, Lesley Milicich, Mary Murray, Sushila Pillai, Patricia Stein, Sandra Taylor and Lesley Thompson. For technical support and academic guidance that was 'above and beyond' I sincerely thank Marti Anderson, Martyn Kennedy, Kylie Price and Chris Thorn.

For logistical support I acknowledge Antarctica New Zealand, in particular Shulamit Gordon (LGP manager) and Brian Staite (LGP camp manager). I am also grateful to the Australian Antarctic Division for hosting me at Casey Station in 2005 and the captain and crew of the Aurora Australis for a fantastic voyage.

For funding, I thank Victoria University of Wellington, New Zealand Post, Antarctica New Zealand, the Trans-Antarctic Association, the Antarctic Research Center (VUW) Endowed Development Fund, the Royal Society of New Zealand and Education New Zealand. For sponsorship, I gratefully acknowledge the support of Kathmandu Clothing and ADIDAS New Zealand.

Lastly, I would like to thank my mum, dad, Gareth and Kelly. Your encouragement and unconditional support (especially during the notorious 'stage 5' of writing up) has got me to where I am today - thank you for always being there.... 


\section{Table of Contents}

Abstract

Acknowledgements

CHAPTER 1: Microbial loop dynamics in Antarctic sea-ice: introduction \& overview

1.1 Microbial life and the Antarctic sea-ice ecosystem

1.2 The microbial loop: what goes around comes around?

1.3 Microbial loop dynamics in Antarctic sea-ice

1.4 Thesis structure

1.5 Literature cited

CHAPTER 2: High single-cell metabolic activity in Antarctic sea-ice bacteria

2.1 Abstract

2.2 Introduction

2.3 Materials and methods

2.3.1 Study site

2.3.2 Direct Viable Count (DVC)

2.3.3 LIVE/DEAD BacLightTM

2.3.4 ViaGramTM Red+

2.3.5 modified Vital Stain and Probe (mVSP)

2.3.6 Nucleic Acid Double Staining (NADS)

2.3.7 CTC

2.3.8 Statistical analyses

2.4 Results

2.4.1 Viability staining

2.4.2 Activity probes

2.4.3 Cell growth/division 24

2.5 Discussion 24

2.5.1 Viability staining 28

2.5.2 Activity probes 31

2.5.3 Can activity/viability assays be used in manipulative experiments? 33

2.6 Literature cited 34

CHAPTER 3: Melting moments: low salinity and high UV-B reduce single-cell activity in Antarctic sea-ice bacteria

3.1 Abstract 38

$\begin{array}{ll}3.2 & \text { Introduction } \\ 3.3 & 39\end{array}$

3.3 Materials and methods $\quad 42$

3.3.1 Sample collection $\quad 42$ 
3.3.2 Leucine incorporation rates $\quad 42$

3.3.3 Effect of light and salinity on bottom-ice bacterial cells 43

3.3.4 Effect of UV radiation on bottom ice bottom-ice bacterial cells 45

3.3.5 Statistical analysis $\quad 46$

3.4 Results 47

3.4.1 Leucine incorporation by bottom-ice bacteria $\quad 47$

3.4.2 Single-cell response of bottom-ice bacteria to light and salinity 48

3.4.3 Single-cell response of bottom-ice bacteria to UV-B exposure 49

3.5 Discussion $\quad 51$

$\begin{array}{lll}3.6 & \text { Literature cited } & 58\end{array}$

CHAPTER 4: Can microcosm simulations be used to infer microbial loop dynamics in Antarctic sea-ice?

$\begin{array}{lll}4.1 & \text { Abstract } & 62\end{array}$

4.2 Introduction $\quad 63$

4.3 Materials and methods $\quad 66$

4.3.1 Bottom-ice community experiment 66

4.3.2 Brine community experiment 68

$\begin{array}{lll}\text { 4.3.3 } & \text { Enumeration of bacteria } & 69\end{array}$

4.3.4 Enumeration of CTC+ bacteria 69

4.3.5 Nucleic acid extraction and PCR amplification of bacterial 70 16S rRNA genes

4.3.6 DGGE analysis of 16S rRNA gene fragments 71

$\begin{array}{lll}\text { 4.3.7 Sequencing and comparative sequence analysis } & 71\end{array}$

$\begin{array}{lll}4.3 .8 & \text { Statistical analysis } & 72\end{array}$

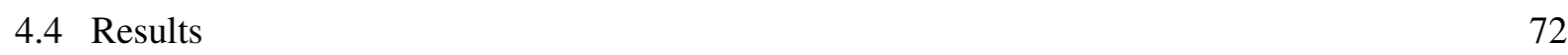

4.4.1 Brine community $\quad 72$

4.4.2 Bottom-ice community $\quad 75$

4.5 Discussion 80

4.5.1 Brine microcosm $\quad 80$

4.5.2 Bottom-ice microcosm $\quad 82$

4.5.3 Light vs. dark incubation? $\quad 83$

4.5.4 DGGE analysis $\quad 84$

4.6 Literature cited 86

CHAPTER 5: In situ response of sea-ice microbes to habitat variability: insight into community dynamics or just another 'flippin ice core'?

$\begin{array}{llr}5.1 \text { Abstract } & 88\end{array}$

$\begin{array}{ll}5.2 \text { Introduction } & 89\end{array}$

5.3 Materials and methods $\quad 93$

5.3.1 Ice cores 93

$\begin{array}{ll}\text { 5.3.2 Physical measurements } & 94\end{array}$

$\begin{array}{lll}\text { 5.3.3 Chlorophyll a } & 94\end{array}$

5.3.4 Enumeration and identification of microalgae and protozoa 94 
5.3.5 Enumeration of bacteria 95

5.3.6 Nucleic acid extraction and PCR amplification of bacterial 96 16S rRNA genes

5.3.7 DGGE analysis of 16S rRNA gene fragments 96

5.3.8 Sequencing and comparative sequence analysis 97

$\begin{array}{lll}\text { 5.3.9 Statistical analyses } & 98\end{array}$

$\begin{array}{lll}\text { 5.3.9.1 Univariate analysis } & 98\end{array}$

$\begin{array}{lll}\text { 5.3.9.2 Multivariate analysis } & 98\end{array}$

$\begin{array}{ll}5.4 \text { Results } & 100\end{array}$

5.4.1 Physical measurements $\quad 100$

5.4.2 Distribution and abundance of sea-ice microbes 101

$\begin{array}{ll}5.4 .3 \text { Community composition } & 103\end{array}$

5.5 Discussion 116

5.5.1 Resistance, resilience, or redundancy of sea-ice microbial communities? 127

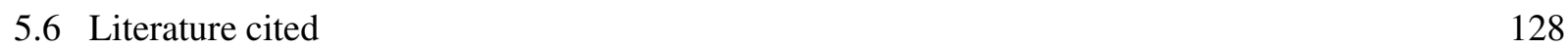

CHAPTER 6: The microbial loop: full circle and future prospects 132

6.1 Introduction 132

6.2 Summary of findings $\quad 132$

6.2.1 Chapter 2: High-single cell metabolic activity in Antarctic sea-ice bacteria 132

6.2.2 Chapter 3: Melting moments: low salinity and high UV-B reduce single-cell activity in 133 Antarctic sea-ice bacteria

6.2.3 Chapter 4: Can microcosm simulations be used in infer microbial loop dynamics in 134 Antarctic sea-ice bacteria?

6.2.4 Chapter 5: In situ response of sea ice microbes to habitat variability: insight into habitat 135 variability or just another 'flippin ice core'?

6.3 Discussion and synopsis 136

6.4 Recommendations for future research $\quad 142$

$\begin{array}{lll}6.5 & \text { Literature cited } & 144\end{array}$

APPENDIX 1: Methodological information referred to in thesis 146

$\begin{array}{ll}\text { APPENDIX 2: Additional research } & 147\end{array}$ 


\section{CHAPTER 1}

Microbial loop dynamics in Antarctic sea-ice: introduction \& overview

\subsection{Microbial life and the Antarctic sea-ice ecosystem}

Microorganisms have been fundamentally important to the history and function of life on Earth. They have played a central role in the climatic, geological, and biological evolution of the planet (Xu 2006). Microbial life is found in every conceivable ecological niche: from the tropics to the poles, from underground mines and oil fields to the stratosphere and mountain ranges; from deserts to the Dead Sea, and hot springs to underwater hydrothermal vents (eg. Junge et al. 2002, Nagy et al. 2005, McCliment 2006, Soo et al. 2009). Microbes dominate the flux of energy and biologically important chemical elements in the world's oceans and, as a result, are estimated to be five to ten times the mass of all multicellular marine organisms (Pomeroy et al. 2007). The number of marine bacteria alone is estimated to be $10^{29}$, which is more than the estimated $10^{21}$ stars in the universe (Whitman et al. 1998). These cells are a potential reservoir of useful genes for medicine and biotechnology, and unravelling the complex taxonomic diversity of prokaryotes is considered the key to understanding the process of evolution (Pace 1997, Pedrós-Alió 2006).

Covering approximately $10 \%$ of the world's oceans, the Southern Ocean is a significant component of the global marine biome and can be characterised by regional ecosystems and gradients in biological communities that extend from coastlines to the open ocean (Constable and Nicol 2003, Nicol et al. 2008). The 
pelagic ecosystem of the Southern Ocean can be defined by distinct provinces that include the polar front zone, the permanently open ocean zone, the sea-ice zone, and the coastal and continental shelf (Arrigo \& Thomas 2004, Nicol et al. 2008). The seaice zone is arguably one of the most significant, albeit ephemeral, habitats on the planet, and ice-associated microbial communities are intimately linked to production and trophodynamics in coastal regions of Antarctica.

The annual circumpolar expansion of sea-ice around Antarctica provides a stable platform for the colonisation and growth of a diverse assemblage of microbes that are scavenged from the water column and then confined to a semi-solid matrix of pores and brine channels within the ice (Garrison 1991, Thomas \& Dieckmann 2002, Arrigo \& Thomas 2004). Despite strong vertical gradients in light, temperature, salinity, and dissolved organic matter (DOM), a suite of physiological and biochemical adaptations allow psychrophilic (organisms capable of growth at or below $0^{\circ} \mathrm{C}$ ) bacteria and microalgae to dominate the sea-ice biota (Arrigo \& Sullivan 1992, McMinn et al. 1999, Arrigo \& Thomas 2004). Although the internal arrangement of microbial habitats is influenced by ice structure (fast-ice remains attached to the shoreline, whereas free-floating pack ice extends into deep-water regions), microbial communities are present in discrete assemblages throughout the ice (Garrison 1991, Vincent 1988).

Increasing evidence suggests that the sea-ice microbial community is integral to productivity and trophodynamics in ice-covered regions of the Southern Ocean (Garrison 1991, Arrigo \& Thomas 2004, Garrison et al. 2005). The seasonal pattern of in situ primary and bacterial secondary production both extends and increases 
regional productivity, and the accumulated biomass is an important seasonal resource for crustaceous zooplankton such as the Antarctic krill Euphausia superba Dana (Daly 1990, Kottmeier \& Sullivan 1990). In addition, it is likely that bacteria and microalgae released from melting ice contribute to bloom events at the receding ice edge in the austral summer and participate in a microbial loop within the ice, which may in turn support higher trophic levels (Giesenhagen et al. 1999, Brierley \& Thomas 2002, Garrison et al. 2005).

\subsection{The microbial loop: what goes around comes around?}

The microbial loop paradigm has assumed a central role in the study of many aquatic ecosystems and suggests that a significant portion of organic carbon does not flow directly to higher trophic groups, but is initially cycled through a loop comprised of phytoplankton, bacteria and phagotrophic protozoa (McKenna et al. 2006, Azam \& Malfatti 2007). The term 'microbial loop' was first coined by Azam et al. (1983) in a review paper suggesting that the structure of marine plankton communities was incomplete and overly simplistic. A new supposition offered by these authors was that the substantial amount of primary production initially lost to the environment as DOM, is in fact utilised as a metabolic resource by heterotrophic bacteria. The consumption of bacteria by protozoa was hypothesised to make the energy available to larger taxa in what is generally referred to as the 'classic' food chain (Fenchel 2008). This theory instigated a complete reassessment of the ecological significance of microbes and provided the scientific stimulus that has increased our understanding not only of the diversity and metabolic capabilities of the marine microbial biota, but has subsequently added levels of complexity of the microbial loop (see Kirchman 2000, Fenchel 2008 for reviews) (Figure 1.1). The field of marine microbial ecology 
continues to rapidly develop and we can now accurately answer a prescient question raised by Darwin (1845) over 150 years ago:

\section{"I presume that the numerous lower pelagic animals persist on the infusoria, which are known to abound in the open ocean: but on what, in the clear blue water, do these infusoria subsist?"}

However, while the microbial loop has certainly become a central tenet in the field of microbial ecology, increasing evidence suggests that large gaps remain in understanding the role of bacteria (Darwin's 'infusoria') in regulating the flux of oceanic carbon (Gasol et al. 2008). These gaps relate to essential methodological issues, such as whether bacterial production (the uptake of radiolabeled amino acids) should be measured in the light or in the dark, and how accurate measures of bacterial growth efficiency are best obtained. In addition, the trophic links that are inherent to the microbial loop remain poorly characterised, even in ecosystems as fundamentally important as Antarctic sea-ice.

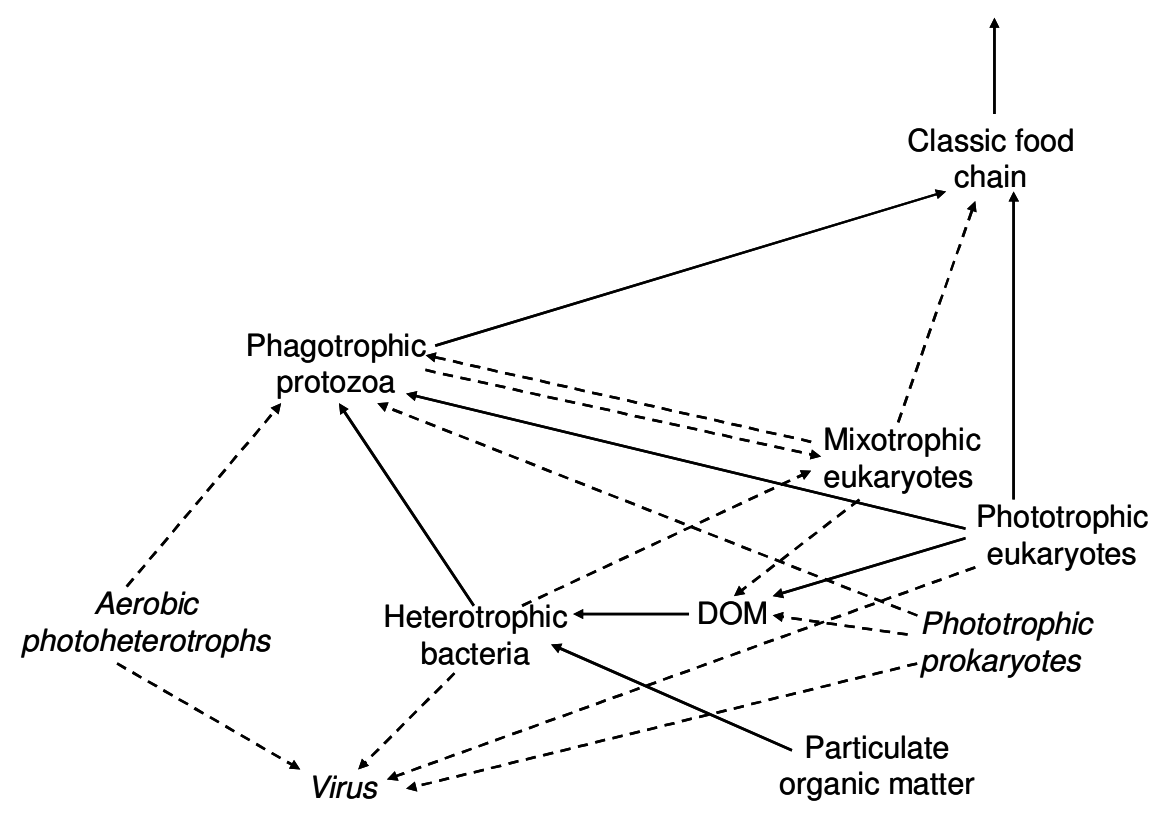

Figure 1.1: The microbial loop as first described by Azam et al. (1983)(solid arrows) and with later additions (stippled arrows). DOM refers to dissolved organic matter. Image adapted from that of Fenchel (2008). 


\subsection{Microbial loop dynamics in Antarctic sea-ice}

Reference to a functional microbial loop within Antarctic sea-ice was first made by Sullivan and co-workers in the 1980's who conducted seminal research on sea-ice microbial communities in McMurdo Sound, Antarctica. Sullivan (1985) postulated that bacteria play an important role in the following processes:

- Secondary microbial production mediated through the microbial loop.

- Remineralisation and recycling of ice-associated organic matter.

- Maintenance of a balance in the ice microenvironment with regard to detoxification and oxygen consumption.

- Trace gas production.

- Ice nucleation and early stages of sea-ice formation.

Despite numerous insights into the taxonomic diversity and ecology of sea-ice bacteria that have been made in the decades that followed (see Thomas \& Dieckmann 2002, Mock \& Thomas 2005, Murray \& Grzymski 2007 for reviews), the postulates of Sullivan remain largely unsubstantiated. A possible exception is the involvement of bacteria in a microbial loop and the remineralisation of organic matter within the ice (Figure 1.2). Although phototrophy in the sea-ice ecosystem is characterised by high spatial and temporal variability, microalgae contribute directly to the in situ concentration of DOM available for bacterial metabolism by exuding photosynthate during the process of photosynthesis. In addition, bacteria also consume the extracellular polymeric substances (EPS) that microalgae release (mostly acid mucopolysaccharides) for functions that include cryoprotection, adhesion, locomotion, and habitat stabilisation (Meiners et al. 2004, Mock \& Thomas 2005). Microalgae may also contribute indirectly to the concentration of DOM by the 
viral lysis of host algal cells and 'sloppy feeding'; the rupture and degradation of cells associated with protozoan grazing (Günther et al. 1999, Staley \& Gosink 1999, Scott et al. 2001, Garrison et al. 2005). In return, bacteria are thought to facilitate continued algal growth by providing remineralised inorganic nutrients such as phosphate, nitrate, and ammonia (Grossi et al. 1984, Kottmeier et al. 1987).

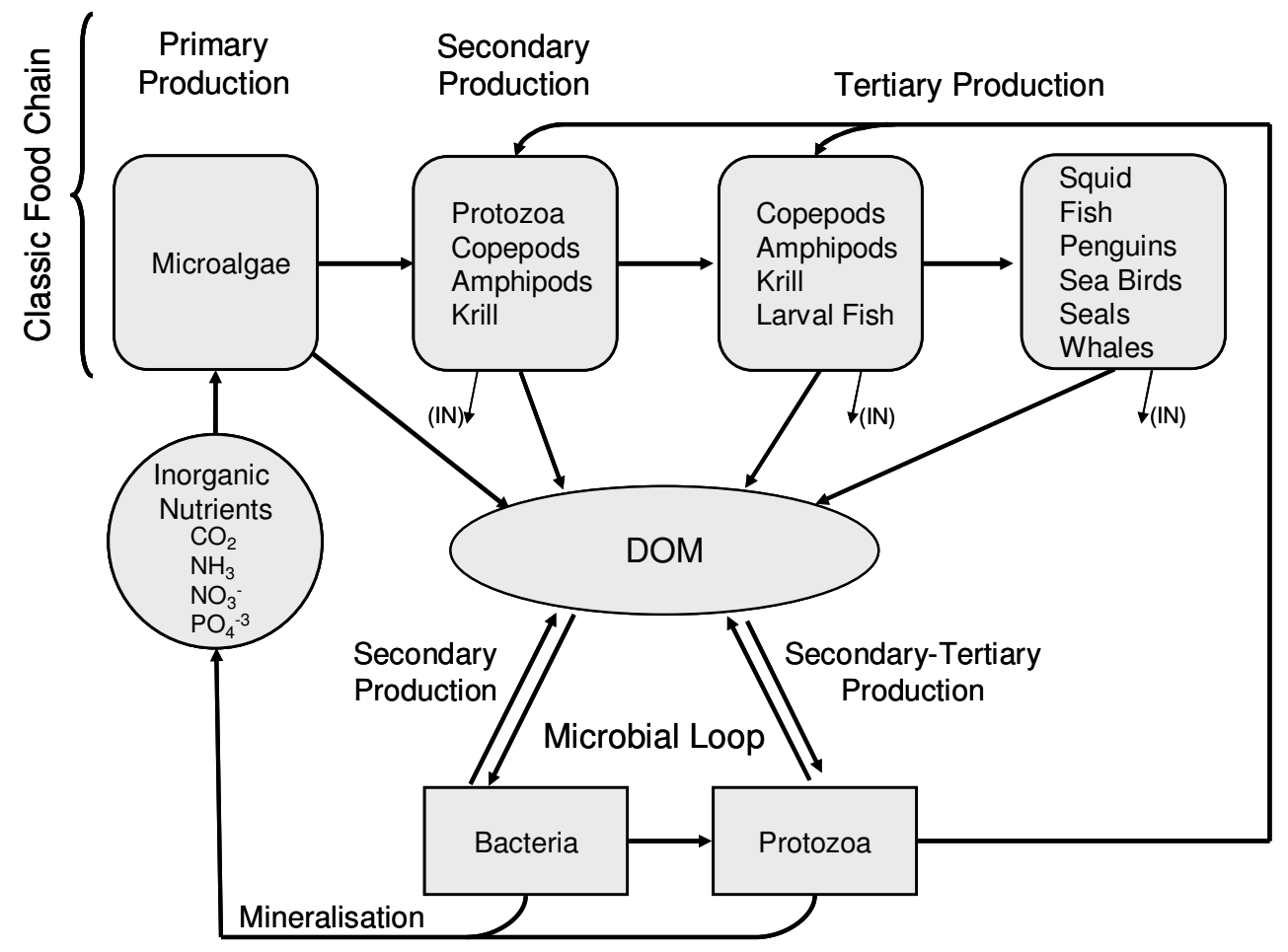

Figure 1.2: Energy flow within Antarctic sea-ice and links to the Southern Ocean pelagic ecosystem. DOM refers to dissolved organic matter. Image adapted from that of Kottmeier et al. (1987).

An active microbial loop in Antarctic sea-ice has historically been implied by regression analysis and correlation between microalgae (or proxies such as chlorophyll $a$ ) and estimates of bacterial abundance or production (see Stewart \& Fritsen 2004). Clearly, a full understanding of in situ microbial dynamics in the sea ice ecosystem requires a significantly finer degree of experimental resolution. Providing this insight is the central aim of this thesis. 


\subsection{Thesis structure}

In this thesis, I examine the assimilation of algal-derived DOM by Antarctic sea-ice bacteria. By integrating a range of physiological, molecular, and ecological techniques, I examine this key process in the microbial loop, beyond the use of bulk comparisons. The overarching questions addressed in this thesis are:

1. Does the single-cell analysis of sea-ice bacteria provide insight into microbial loop dynamics in Antarctic sea-ice, specifically the assimilation of algalderived DOM?

2. To what extent can in vitro culture-based experiments be used to infer microbial loop dynamics in Antarctic sea-ice?

3. What is the in situ response of Antarctic sea-ice microbes to habitat variability and trophic dynamics?

Because a significant fraction of the bacterial cells enumerated from marine ecosystems are either dead or relatively inactive, identifying the factors that influence the in situ metabolism of bacterial populations, and understanding how this varies in space and time, remains a major question in microbial ecology. Importantly, the metabolic status of bacteria largely determines their role in microbial loop dynamics and nutrient cycling (Davidson et al. 2004, Pearce et al. 2007). Although a variety of methods are now available that assess the physiological status of individual bacterial cells, there is no consensus regarding the validity of these methods (Howard-Jones et al. 2001). In Chapter 2, I evaluate a range of stains and probes to determine the single-cell activity of Antarctic sea-ice bacteria. I also examine whether physiological probes can be used to quantify change in bacterial 
activity during short-term manipulative experiments. An abbreviated version of Chapter 2 has been published as:

Martin A, Hall JA, Davy SK, O’Toole R, Ryan KG (2008) High single-cell metabolic activity in Antarctic sea-ice bacteria. Aquatic Microbial Ecology 32: 51-54.

Despite the implications for microbial loop dynamics, bacterial adaptation to the physicochemical extremes of the sea-ice habitat is not well understood. In Chapter 3, I examine the response of sea-ice microbes to saline and irradiance regimes associated with the annual freeze/thaw of the ice matrix. Specifically, I determine whether variation in the production of algal-derived DOM influences the real-time, single-cell response of bacteria using the assay deemed most appropriate in Chapter 2. In addition, I examine whether the rapid exposure to increased UV-B radiation during ice melt limits the capacity of ice-derived bacteria to initiate ice edge blooms. An abbreviated version of Chapter 3 has been published as:

Martin A, Hall JA, Ryan KG (in press, 2009) Low salinity and high-level UV-B radiation reduce single-cell activity in Antarctic sea-ice bacteria. Applied and Environmental Microbiology 75: 7570-7573.

Chapter 4 builds on the previous chapters by examining the response of sea-ice bacteria to variation in the photosynthate exuded by microalgae over a period of 9 days. Using microcosm simulations, I document changes in intracellular activity, cell abundance and community composition. Chapter 4 is currently in review:

Martin A, Hall JA, Miller HC, Ryan KG (In review) Can microcosm simulations be used to infer microbial loop dynamics in Antarctic sea-ice? Marine Biology. 
In the final data chapter, Chapter 5, I conduct a reciprocal transplant experiment to examine the in situ response of sea-ice microbes to habitat variability. By extracting a series of ice cores and reinserting them back into the ice matrix upside down, I document changes in the relative abundance of bacteria and microalgae and examine how abiotic variables influence community composition and microbial dynamics. Chapter 5 is currently in preparation for submission to Environmental Microbiology:

Martin A, Anderson MJ, Thorn C, Ryan KG (In prep) In situ response of sea-ice microbes to habitat variability: insight into community dynamics or just another 'flippin' ice core'?

Because this thesis is written as a series of independent manuscripts, there is some repetition of general information in the individual chapters. Chapters 2-5 each include an introduction with specific aims and a discussion which links the empirical data to the current literature. Lastly, Chapter 6 provides a summary and synthesis of the proceeding chapters and outlines directions for future research.

\subsection{Literature cited}

Arrigo KR, Sullivan CW (1992) The influence of salinity and temperature covariation on the photophysiological characteristics of Antarctic sea ice microalgae. Journal of Phycology 28: 746-756.

Arrigo KR, Thomas DN (2004) Large scale importance of sea ice biology in the Southern Ocean. Antarctic Science 16: 471-486.

Azam F, Fenchel T, Field JG, Gray JS, Meyer-Reil LA, Thingstad F (1983) The ecological role of water-column microbes in the sea. Marine Ecology Progress Series 10: 257-263.

Azam F, Malfatti F (2007) Microbial structuring of marine ecosystems. Nature Reviews Microbiology 5: 782-791.

Azam F, Fenchel T, Field JG, Grey JS, Meyer-Reil LA, Thingstad F (1983) The ecological role of water-column microbes in the sea. Marine Ecology Progress Series 10: 257-263.

Brierley AS, Thomas DN (2002) Ecology of Southern Ocean pack ice. Advances in Marine Biology 43: 171-276.

Constable AJ, Nicol S (2003) Southern Ocean productivity in relation to spatial and temporal variation in the physical environment. Journal of Geophysical Research 108: 6-1-6-21.

Daly KL (1990) Overwintering development, growth, and feeding of larval Euphausia superba in the Antarctic marginal ice zone. Limnology and Oceanography 35: 15641576. 
Darwin C (1845) Journal of researches into the natural history and geology of the countries visited during the voyages of H.M.S Beagle round the world, under the Command of Capt. Fitz Roy, RN. 2nd ed. John Murray, London, 519 p.

Davidson AT, Thomson PG, Westwood K, van den Enden R (2004) Estimation of bacterioplankton activity in Tasmanian coastal waters and between Tasmania and Antarctica using stains. Aquatic Microbial Ecology 37: 33-45.

Fenchel T (2008) The microbial loop - 25 years later. Journal of Experimental Marine Biology and Ecology. 366: 99-03.

Garrison DL (1991) Antarctic Sea Ice Biota. American Zoologist 31: 17-33.

Garrison DL, Gibson A, Coale SL, Gowing, MM, Okolodkov YB, Fritsen HF, Jeffries MO (2005) Sea-ice microbial communities in the Ross Sea: autumn and summer biota. Marine Ecology Progress Series 300: 39-52.

Gasol JM, Pinhassi J, Alonso-Sáez L, Ducklow H, Herndl GJ, Koblížek M, Labrenz M, Luo Y, Morán XAG, Reinthaler T, Simon M (2008) Towards a better understanding of microbial carbon flux in the sea. Aquatic Microbial Ecology 53: 21-38.

Giesenhagen HC, Detmer AE, de Wall J, Weber A, Gradinger RR, Jochem, FJ (1999) How are Antarctic planktonic microbial food webs and algal blooms affected by melting of sea ice? Microcosm simulations. Aquatic Microbial Ecology 20: 183-201.

Günther S, Gleitz M, Dieckmann GS (1999) Biogeochemistry of Antarctic sea ice: a case study on platelet ice layers at Drescher Inlet, Weddell Sea. Marine Ecology Progress Series 177: 1-13.

Grossi SM, Kottmeier ST, Sullivan CW (1984) Sea Ice Microbial Communities III. Seasonal abundance of microalgae associated bacteria in McMurdo Sound, Antarctica. Microbial Ecology 10: 231-242.

Howard-Jones MH, Frischer ME, Verity PG (2001) Determining the physiological status of individual bacterial cells. In: Paul J (ed) Methods in microbiology, vol 30, marine microbiology. Academic Press, p 175-206.

Junge K, Imhoff F, Staley T, Deming W (2002) Phylogenetic diversity of numerically important Arctic sea-ice bacteria cultured at subzero temperatures. Microbial Ecology 43: 315-328.

Kirchman DL (2000) Microbial ecology of the oceans. Wiley-Liss, New York, 552 p.

Kottmeier ST, Sullivan CW (1990) Bacterial biomass and production in pack ice of Antarctic marginal ice edge zones. Deep-Sea Research 37: 1311-1330.

McKenna KC, Mooread DL, Roberts EC, Laybourn-Parry J (2006) Simulated patterns of carbon flow in the pelagic food web of Lake Fryxell, Antarctica: little evidence of topdown control. Ecological Modelling 192: 457-472.

McCliment EA, Voglesonger KM, O’Day PA, Dunn EE, Holloway JR, Cary SC (2006) Colonisation of nascent, deep-sea hydrothermal vents by a novel Archaeal and Nanoarchaeal assemblage. Environmental Microbiology 8: 114-125.

McMinn A, Skerratt J, Trull T, Ashworth C, Lizotte M. (1999) Nutrient stress gradient in the bottom $5 \mathrm{~cm}$ of fast ice, McMurdo Sound, Antarctica. Polar Biology 21: 220-227.

Mock T, Thomas DN (2005) Recent advances in sea-ice microbiology. Environmental Microbiology 7: 605-619.

Murray AE, Grzymski JJ (2007) Diversity and genomics of Antarctic marine microorganisms. Philosophical Transactions of the Royal Society B 362: 225-2271.

Nagy ML, Perez A, Garcia-Pichel F (2005) The prokaryotic diversity of biological soil crusts in the Sonorian Desert (Organ pipe cactus national monument, AZ). FEMS Microbiology Ecology 54: 233-245.

Nicol S, Worby A, Leaper R (2008) Changes in the Antarctic sea ice ecosystem: potential effects on krill and baleen whales. Marine and Freshwater Research 59: 361-382.

Pace NR (1997) A molecular view of microbial diversity and the biosphere. Science 276: 734-740.

Pearce I, Davidson AT, Bell EM, Wright S. Seasonal changes in the concentration and metabolic activity of bacteria and viruses at an Antarctic coastal site. Aquatic Microbial Ecology 47: 11-23. 
Pedrós-Alió C (2006) Marine microbial diversity: can it be determined? TRENDS in Microbiology 14: 257-263.

Pomeroy LR, Williams PJ, Azam F, Hobbie JE (2007) The microbial loop. Oceanography 20: 28-33.

Scott FJ, Davidson AT, Marchant HJ (2001) Grazing by the Antarctic sea-ice ciliate Pseudocohnilembus. Polar Biology 24: 127-131.

Soo RM, Wood SA, Grzymski JJ, McDonald IR, Cary SC (2009) Microbial biodiversity of thermophilic communities in hot mineral soils of Tramway Ridge, Mount Erebus, Antarctica. Environmental Microbiology 11: 715-728.

Staley JT, Gosink JJ (1999) Poles apart: biodiversity and biogeography of sea ice bacteria. Annual Reviews of Microbiology 53: 189-215.

Stewart FJ, Fritsen CH (2004) Bacteria-algae relationships in Antarctic sea ice. Antarctic Science 16: 143-156.

Sullivan CW (1985) Sea ice bacteria: Reciprocal interactions of the organisms and their environment. In: Horner R (ed) Sea ice biota. Chemical Rubber Company, Boca Raton, p 160-171.

Thomas DN, Dieckmann GS (2002) Antarctic sea ice - a habitat for extremophiles. Science 295: 641-644.

Vincent WF (1988) Microbial ecosystems of Antarctica. Cambridge University Press, 304 p.

Whitman WB, Coleman DC, Wiebe WJ (1998) Prokaryotes. The unseen majority. Proceedings of the National Academy of Sciences of the United States of America 95: 6578-6583.

$\mathrm{Xu} \mathrm{J}$ (2006) Microbial ecology in the age of genomics and metagenomics: concepts, tools, and recent advances. Molecular Ecology 15: 1713-1731. 


\section{CHAPTER 2}

High single-cell metabolic activity in Antarctic sea-ice bacteria

\subsection{Abstract}

Antarctic sea-ice bacteria have historically been examined by techniques that measure bulk community properties. In recognition of the complexity of microbial community structure and function, methods are now available to assess the physiological status of individual bacterial cells, but a consensus as to the effectiveness of these protocols is lacking. I employed viability (LIVE/DEAD BacLight ${ }^{\mathrm{TM}}$, ViaGram ${ }^{\mathrm{TM}}$ Red $^{+}$and Nucleic Acid Double Staining (NADS) and activity assays (modified Vital Stain and Probe (mVSP), and 5-cyano-2,3-ditolyl tetrazolium chloride (CTC)) to quantify the single-cell metabolic status of sea-ice bacteria and the Direct Viable Count (DVC) assay to assess cell growth/division. This approach was used to (1) quantify the metabolic status of bacteria present in the congelation layer (bottom) of Antarctic fast-ice and (2) determine whether physiological probes can be used to quantify short-term changes in bacterial metabolic activity. Each assay was used in short $(<8 \mathrm{hr})$ manipulative experiments conducted on bacteria from melted ice cores with dark/light $\left(5 \mu \mathrm{mol}\right.$ photons $\left.\mathrm{m}^{-2} \mathrm{~s}^{-1}\right)$ and presence/absence of microalgae (filtered, unfiltered samples) as treatment variables. Estimates of cell viability (intact membranes) were $>68 \%$ (NADS) and $>90 \%\left(\right.$ ViaGram $^{\mathrm{TM}} \operatorname{Red}^{+}$, mVSP) of the post-incubation cell count. High cellular rRNA content was observed using fluorescence in situ hybridisation with an average of $80 \%$ of DAPI-stained cells hybridising with the general bacterial probe EUB338 (mVSP). An average of 
$32 \%$ of the bacterial cells were undergoing active respiration (CTC+) which is significantly higher than the 2 to $10 \%$ level of activity typical for most marine systems. LIVE/DEAD BacLight ${ }^{\mathrm{TM}}$ results were inconclusive and no in vitro growth was observed using the DVC protocol. The short-term effect of irradiance or manipulation of microalgal photosynthate was not significant for any assay. Singlecell analysis of melted ice cores suggests that sea-ice is among the most productive microbial habitats, while CTC is favoured for establishing a real-time bacterial response in the sea-ice ecosystem.

\subsection{Introduction}

While bacteria are now recognised as a major biological force in the oceanic carbon cycle and ecosystem structure (Delille 1996, Azam \& Worden 2004), our understanding of the diversity and functional capabilities of bacteria in Antarctic seaice remains fragmentary. There is, however, increasing evidence to suggest that bacterial communities play an ecologically important role in Antarctic ice-covered marine regions (Garrison et al. 2005). As sea-ice forms, dissolved salts are excluded from the freshwater ice matrix and microbes become concentrated in microscopic pockets of liquid brine within the ice (Garrison, 1991). Estimates of the seasonal abundance of bacteria in both fast- and pack-ice environments, coupled with measurements of high biomass production, have led several authors to propose an active microbial loop operating within sea-ice, which is similar in function to that of temperate marine systems (Sullivan \& Palmisano 1984, Azam et al. 1991). However, the links between the growth and production rates of bacteria with higher trophic levels in the microbial loop have yet to be clearly defined. Bacterial assimilation of dissolved organic matter (DOM) is a core process in the microbial loop hypothesis 
(Azam et al. 1991), but remains equivocal with respect to the spatial and temporal variability of the sea-ice community (Stewart \& Fritsen 2004).

To understand the ecology of microbial communities, information about the identity and metabolic activity of individual microbes is needed (Sherr et al. 2001). A variety of stains and probes are now available that provide insight into the level of singlecell activity; these techniques target a number of properties associated with cellular physiology such as membrane integrity, specific enzyme activity, ribosomal RNA content and cellular reducing potential (Howard-Jones et al. 2001). Single-cell analyses provide a high degree of experimental resolution, but there is currently no consensus regarding the validity of these methods (Smith \& del Giorgio 2003, Schumann et al. 2003), or even which are the most reliable (Joux \& Lebaron 2000, Howard-Jones et al 2001, Davidson et al. 2004). Importantly, it is becoming evident that bacterial communities can exhibit a range of physiological states including viable non-culturable, dormant and active. In light of this, Smith \& del Giorgio (2003) have suggested that only a combination of methods will effectively describe community metabolic activity.

This study is the first to examine single-cell metabolic activity in Antarctic sea-ice bacteria using a range of protocols. I examine membrane integrity (Nucleic Acid Double Staining [NADS] and modified Vital Stain and Probe [mVSP]), ribosomal RNA content (mVSP), cellular respiration (5-cyano-2,3-ditolyl tetrazolium chloride [CTC]) and cell division (Direct Viable Count [DVC] in Antarctic sea-ice bacteria. Specifically, I (1) quantify the cell-specific metabolic status of bacteria present in the bottom of Antarctic fast-ice and (2) determine whether physiological probes can be 
used to quantify potential changes in bacterial metabolic activity during short-term manipulative experiments.

\subsection{Materials and methods}

\subsubsection{Study site}

Sea-ice bacteria and microalgae were collected in November 2004 from fast-ice approximately $1.5 \mathrm{~m}$ thick at Cape Hallett, Antarctica (72 $\left.19^{\circ} \mathrm{S}, 170^{\circ} 13^{\prime} \mathrm{E}\right)$. A series of holes $(<1.2 \mathrm{~m})$ were drilled in close proximity with a powered ice auger (Jiffy, USA) and cores (200 to $300 \mathrm{~mm}$ long, $130 \mathrm{~mm}$ diameter) were extracted from the bottom of each profile using a Kovaks (Kovaks, USA) ice corer. To minimise light shock, all operations were performed under a black sheet and each core was transported in a black plastic tube. Bottom-ice bacteria and microalgae were obtained by cutting off the bottom $50 \mathrm{~mm}$ of each core and melting this into three times the quantity of $0.22 \mu \mathrm{m}$-filtered seawater $\left(35 \%,-1.8^{\circ} \mathrm{C}\right)$, under low light $(<1 \mu \mathrm{mol}$ photons $\mathrm{m}^{-2} \mathrm{~s}^{-1}$ ), in sterile containers over a period of $12 \mathrm{~h}$ (Ryan et al. 2004). Throughout the melting process cells remained at $-1.8^{\circ} \mathrm{C}$ as the process of ice melt maintains the temperature equilibrium. For each experiment, the cells from 3-4 melted cores were combined in a single container with a typical final volume of 500 $\mathrm{ml}$. To remove the majority of microalgal cells (typically 10 to $100 \mu \mathrm{m}$ in length) for the filtered treatment, approximately $250 \mathrm{ml}$ of the initial stock was passed through a series of filters; two filter nets $(50 \mu \mathrm{m}$ and $5 \mu \mathrm{m})$ followed by vacuum filtration with a $3 \mu \mathrm{m}$ filter (Millipore, USA).

Incubations were performed in a water bath maintained at $-1.8^{\circ} \mathrm{C}$. An ethanol: water (1:4) mix was used to provide subzero temperatures, and a heater stirrer was used to 
maintain the incubator to within $\pm 0.2^{\circ} \mathrm{C}$. During incubations, samples were assigned to either a light $\left(5 \mu \mathrm{mol}\right.$ photons $\left.\mathrm{m}^{-2} \mathrm{~s}^{-1}\right)$ or dark treatment and two algal cell concentrations; filtered or unfiltered. A schematic of the staining regime is shown in Figure 2.1.

\subsubsection{Direct Viable Count (DVC)}

To determine single-cell growth and division rates, $1 \mathrm{ml}$ samples of the filtered stock (only) were transferred to sterile Eppendorf tubes. Three $1 \mathrm{ml}$ samples were fixed with formalin ( $2 \%$ final concentration) to determine bacterial cell numbers prior to incubation. Duplicate samples of each experimental replicate were then prepared, one of which was spiked with the antibiotic nalidixic acid (Sigma, USA) at a final concentration of $20 \mu \mathrm{g} \mathrm{ml}^{-1}$ to prevent cell division in active cells. Yeast extract (generally used with this assay) was not used to enrich samples in this experiment so as not to introduce artefacts associated with cultivation. Samples were placed in the water bath for a period of $7 \mathrm{hr}$ then fixed with $0.22 \mu \mathrm{m}$-filtered formalin ( $2 \%$ final concentration) and stored at $4{ }^{\circ} \mathrm{C}$ in the dark. On return to Victoria University of Wellington, New Zealand (VUW), control and experimental samples were stained with DAPI (2.5 $\mu \mathrm{g} \mathrm{ml}^{-1}$ final concentration) for $30 \mathrm{~min}$ (in the dark at ambient temperature). Stained samples were then filtered onto $0.22 \mu \mathrm{m}$ black polycarbonate filters (Sterlitech) backed with $25 \mathrm{~mm} \mathrm{GF/F}$ filters (Millipore, USA) and mounted in VectorShield antifade (Vector Laboratories, USA). Each sample was examined for total and elongated/active cells in 10 randomly chosen fields of view at 1000x magnification using an Olympus Provis AX70 microscope equipped with a blue excitation filter and UV filter set. As the visible enlargement of cells was not 
observed in any antibiotic-spiked samples, total DAPI-stained counts were compared pre- and post-incubation.

\subsubsection{LIVE/DEAD BacLight ${ }^{\mathrm{TM}}$}

To examine cell viability using the LIVE/DEAD Bac Light $^{\mathrm{TM}}$ kit $\left(\right.$ BacLight $\left.^{\mathrm{TM}}\right)($ Molecular Probes, USA), 1ml samples of both the filtered and unfiltered solutions were incubated in sterile Eppendorf tubes for $7 \mathrm{~h}$ at $-1.8 \pm 0.2^{\circ} \mathrm{C}$. Following the incubation period, samples were fixed with $0.22 \mu \mathrm{m}$-filtered formalin (4\% final concentration) and stored at $4^{\circ} \mathrm{C}$ in the dark until analysed at VUW. Staining was carried out following the method detailed by Howard-Jones et al. (2001). Briefly, $3 \mu \mathrm{l}$ of the staining mixture (SYTO-9 and propidium iodide [PI]) was thoroughly mixed with each $1 \mathrm{ml}$ sample and left in the dark for $15 \mathrm{~min}$ at ambient temperature. Stained samples were filtered onto $0.22 \mu \mathrm{m}$ black polycarbonate filters backed with $25 \mathrm{~mm} \mathrm{GF/F}$ filters and mounted in VectorShield antifade. For each slide 200-300 cells were enumerated at 1000x magnification with a Narrow Blue filter set to visualise SYTO-9-stained cells and a Wide Green filter set to visualise PI-stained cells (Olympus Provis AX70).

\subsubsection{ViaGram ${ }^{\mathrm{TM}}$ Red $^{+}$}

Sample preparation and incubation for ViaGram ${ }^{\mathrm{TM}} \operatorname{Red}^{+}\left(\operatorname{ViaGram}^{\mathrm{TM}}\right)$ was identical to the BacLight ${ }^{\mathrm{TM}}$ protocol. Staining was carried out at VUW as per the manufacturer's instructions. Briefly, each sample was centrifuged at $2000 \mathrm{rpm}$ for 1$2 \mathrm{~min}$, washed in $50 \mu \mathrm{lBSA}$-saline then recentrifuged. Cells were resuspended in 50 $\mu \mathrm{l}$ BSA-saline, then stained with $2.5 \mu \mathrm{l}$ of Texas Red-X conjugate of wheat germ agglutinin (WGA) (final concentration $100 \mu \mathrm{g} \mathrm{ml}^{-1}$ ) and incubated for $10 \mathrm{~min}$ (in the dark at ambient temperature). Cells were then centrifuged at $2000 \mathrm{rpm}$ for $2 \mathrm{~min}$ to 
remove the WGA staining solution, resuspended in $50 \mu \mathrm{BSA}$-saline, and stained with $2.5 \mu$ of the DAPI/SYTOX Green working solution supplied with the kit. After a dark incubation of $10 \mathrm{~min}$ (ambient temperature) the volume of each sample was increased to $1 \mathrm{ml}$ by adding BSA-saline and then filtered onto a $0.22 \mu \mathrm{m}$ black polycarbonate filter backed with a $25 \mathrm{~mm} \mathrm{GF/F}$ filter and mounted in VectorShield antifade. For each slide 200-300 cells were enumerated at 1000x magnification with a Narrow Blue filter set (SYTOX Green-stained cells), UV filter set (DAPI-stained cells) and Wide Green filter set (gram positive cells) (Olympus Provis AX70).

\subsection{5 modified Vital Stain and Probe (mVSP)}

The mVSP assay developed by Howard-Jones et al. (2002) was used to detect cellular ribosomal content using fluorescence in situ hybridisation (FISH) with a 16S rRNA-targeted oligonucleotide probe specific for eubacteria, while simultaneously examining membrane integrity. Samples $(15 \mathrm{ml})$ were incubated for a period of $7 \mathrm{~h}$ (to observe possible changes in membrane integrity) at $-1.8 \pm 0.2^{\circ} \mathrm{C}$ in $20 \mathrm{ml}$ glass vials. Samples were then mixed with $5 \mathrm{ml}$ of sterile $99 \%$ glycerol (25\% final concentration) and frozen at $-20^{\circ} \mathrm{C}$. On return to VUW samples were thawed to room temperature. One $\mathrm{ml}$ was extracted from each sample, fixed with methanol (2\% final concentration) and incubated for $3 \mathrm{~min}$ (in the dark at ambient temperature) in order to stabilise cell membranes. Cells were then simultaneously stained with DAPI (final concentration $3 \mu \mathrm{g} \mathrm{ml}^{-1}$ ) and PI (final concentration $0.2 \mu \mathrm{g} \mathrm{ml}^{-1}$ ) and incubated for 30 min (in the dark at ambient temperature). To permeabilise/dehydrate the cells $200 \mu 1$ of ethanol/formaldehyde $(90: 10 \mathrm{v} / \mathrm{v})$ was added before incubating for a further 30 $\min$ (in the dark, $\pm 2{ }^{\circ} \mathrm{C}$ of ambient). Samples were then filtered onto $0.22 \mu \mathrm{m}$ black polycarbonate filters backed with $25 \mathrm{~mm}$ GF/F filters and washed several times with 
$1 \mathrm{ml}$ aliquots of $10 \mathrm{mM} \mathrm{MgSO}_{4}$. Each filter was carefully overlaid with a probe/hybridisation solution $[0.2 \% \mathrm{w} / \mathrm{v}$ bovine serum albumin $(\mathrm{BSA}), 0.01 \% \mathrm{w} / \mathrm{v}$ polyadenylic acid, 1 x SET (150mM NaCl, 20nm Tris-HCl, 1mM EDTA, pH = 8.0) and $11 \%$ dextran sulfate] with a probe concentration of $340 \mathrm{ng}$. The oligonucleotide probe used in this study was Primer EUB338 (5'gctgcctccegtaggagt) which is specific to positions $338-355$ in the E. coli $16 \mathrm{~S}$ rRNA. The probe was modified with a 5' amino terminus and linked with the flurochrome Alexa Fluor 488 (Molecular Probes). In the original protocol of Howard-Jones et al. (2002) three probes were utilised, but following consultation with the authors, a single probe was deemed adequate. Slides were hybridised overnight at $37^{\circ} \mathrm{C}$ in a humidified chamber, then washed for $30 \mathrm{~min}$ in 3 changes of $1 \times \mathrm{SET}$ at $37^{\circ} \mathrm{C}$, air-dried and mounted with VectorShield antifade. For each slide 200 to 300 cells were observed and total cells (DAPI), dead cells (PI) and active cells (probe positive) were enumerated using Wide UV, Wide Green and Narrow Blue filter sets respectively (Olympus Provis AX70).

\subsubsection{Nucleic Acid Double Staining (NADS)}

Samples initially collected for use with the mVSP assay were also analysed using the double-staining protocol calibrated for marine systems by Grégori et al. (2001). From each of the thawed $15 \mathrm{ml}$ glycerol-treated samples, a further $500 \mu \mathrm{l}$ was simultaneously stained with 1:1,000 (vol/vol) SYBR Green II (Molecular Probes, USA) and PI (final concentration $15 \mu \mathrm{g} \mathrm{ml}^{-1}$ ) for $30 \mathrm{~min}$ (in the dark at ambient temperature). Samples were then analysed on a Becton Dickinson FACScan flow cytometer equipped with a $15 \mathrm{~mW}, 488 \mathrm{~nm}$, air-cooled argon ion laser and standard filter setup. Initial instrument calibration was performed using FACScomp software in conjunction with Becton Dickinson CaliBRITE reference beads. To avoid 
coincidence, samples were run on a medium flow rate with $<1300$ events per second. Each sample was run for $1 \mathrm{~min}$. Becton Dickinson CellQuest software was used for all sample and data analyses. Bacterial cell populations were identified from bivariate plots of FL1 (Green) Vs. FL3 (Red) fluorescence to highlight cells stained with SYBR Green II (live) and PI (damaged, dead) respectively.

To determine the impact of freezing and glycerol storage on the abundance of live and damaged cells, a test was carried out at VUW using the NADS assay. Both intact and membrane-compromised (permeabilised with ethanol/formaldehyde) E. coli cells were added to $15 \mathrm{ml}$ of $0.22 \mu \mathrm{m}$ filtered seawater and then mixed with $5 \mathrm{ml}$ of sterile $99 \%$ glycerol (25\% final concentration). Following a 15 min acclimation period, each sample was stained and analysed as detailed above. The samples were then frozen at $-20^{\circ} \mathrm{C}$ and reanalysed using the NADS assay 2 weeks later.

\subsubsection{CTC}

Intracellular reduction was examined using 5-cyano-2,3-ditolyl tetrazolium chloride (CTC, Polysciences Inc., USA). Samples (900 $\mu \mathrm{l})$ were prepared in $1 \mathrm{ml}$ Eppendorf tubes and allowed to acclimate in the water bath for $4 \mathrm{~h}$ at $-1.8 \pm 0.2^{\circ} \mathrm{C}$. CTC was then added to each sample ( $5 \mathrm{mM}$ final concentration) before being returned to the water bath for a further $3 \mathrm{~h}$. The incubation temperature was maintained at $-1.8 \pm$ $0.2^{\circ} \mathrm{C}$ for the second incubation phase, but samples were not exposed to light. Three blank samples consisting of $0.22 \mu \mathrm{m}$-filtered double distilled water and CTC were incubated under the same conditions described above to control for non-specific signals (i.e. CTC precipitate). Cellular synthesis was subsequently terminated with the addition of $50 \mu \mathrm{l}$ of $0.22 \mu \mathrm{m}$-filtered formalin ( $5 \%$ final concentration) and all 
samples were immediately frozen in liquid nitrogen. CTC-treated samples were transported at $-80^{\circ} \mathrm{C}$ and kept frozen until analysed. Enumeration of $\mathrm{CTC}+$ and total bacterial cells was performed using a Becton Dickinson FACScan flow cytometer (details as described earlier). TruCount beads (Beckton Dickinson, USA) were added to each sample in order to accurately calculate the volume of sample analysed. Bacterial data were typically collected for 3 min (acquisition of 200 TruCount beads) and CTC+ positive cells were identified from bivariate plots of red (FL3) Vs. orange (FL2) fluorescence. Total bacterial counts were determined by re-running each sample following a 10 min incubation with SYBR Green II (Molecular Probes, USA) and examining bivariate plots of green (FL1) fluorescence Vs. SSC (Side Scatter).

\subsubsection{Statistical analyses}

For each viability/activity assay (BacLight ${ }^{\mathrm{TM}}$ excluded) a two-way analysis of variance (ANOVA) was used to test for main effects of light and treatment regimes using SYSTAT (Version 7.0, SPSS Inc.). To determine the effects of glycerol fixation and storage in the NADS control experiment, a paired Student's $t$-test was used to compare the percentage of membrane-compromised cells (PI-stained) as a fraction of the total cell count (SYBR Green II-stained). Data obtained with the DVC assay were compared pre- and post-incubation to determine changes in the number of bacterial cells using a paired Student's $t$-test.

\subsection{Results}

\subsubsection{Viability staining}

Viability data for membrane integrity was, in general, comparable for the ViaGram ${ }^{\mathrm{TM}}$, mVSP and NADS assays, but not the BacLight ${ }^{\mathrm{TM}}$ kit. Of the bacterial cells examined using the NADS assay, approximately $70 \%$ had intact cell membranes and stained 
only with the SYBR Green II dye component (Table 2.1). All remaining cells were double stained and deemed to be 'leaky' (stained with both SYBR Green II and PI), while the number of fully compromised cells (stained with PI only) was negligible.

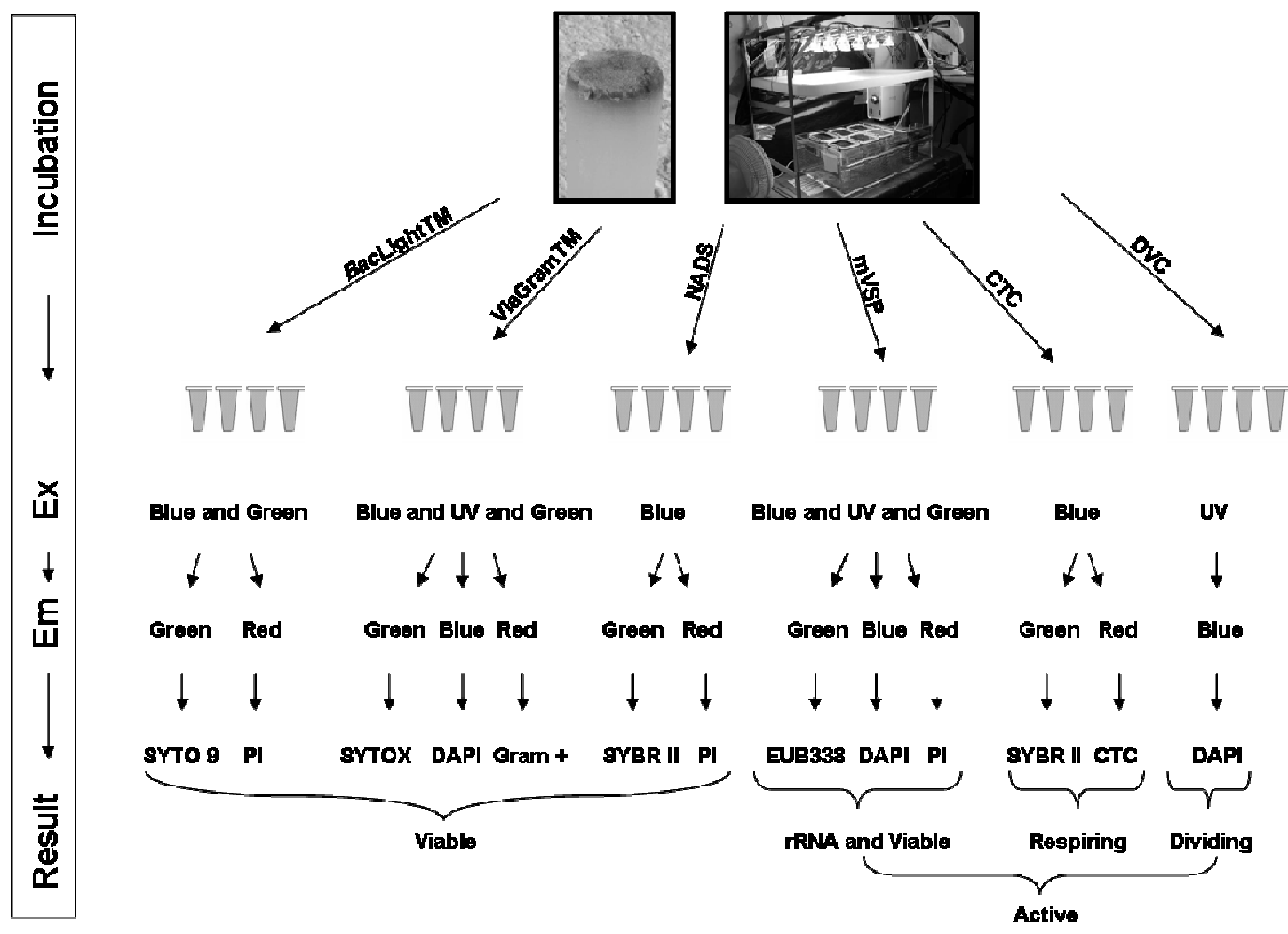

Figure 2.1: Schematic representation of staining regime. Assay $\left(\mathrm{BacLight}^{\mathrm{TM}}=\right.$ LIVE/DEAD BacLight ${ }^{\mathrm{TM}}$ kit, ViaGram $^{\mathrm{TM}}=\mathrm{ViaGram}^{\mathrm{TM}}$ Red $^{+}$kit, NADS $=$Nucleic Acid Double Staining, $\mathrm{mVSP}=$ modified Vital Stain and Probe, CTC = 5-cyano2,3-ditolyl tetrazolium chloride, DVC = Direct Viable Count), excitation (Ex) and emitted fluorescence colour (Em), detail of fluorescent signal (PI = propidium iodide, SYTOX = SYTOX Green, DAPI = 4',6-diamidino-2-phenylindole dihydrochloride, Gram $+=$ conjugate of wheat germ agglutinin, SYBR II $=$ SYBR Green II, EUB338 = Bacteria-specific oligonucleotide probe conjugated to Alexa Flour 488) and resulting cell-specific information.

Determining the relative proportions of intact or leaky bacterial cells using flow cytometry was straightforward using bivariate plots of red (FL3) Vs. green (FL1) fluorescence (Figure 2.2). In the separate control experiment there was no significant difference in the percentage of PI-stained cells between fresh and frozen samples 
using the NADS assay, which indicates that freezing and glycerol storage had no effect on the staining regime $(t=-1.31, \mathrm{df}=2, P=0.321, \mathrm{n}=3)$.

Competition for binding sites using the DAPI/PI component of the mVSP assay revealed significantly fewer compromised or 'leaky' cells compared to the NADS assay. Microscopic counts revealed that the majority of bacterial cells had intact membranes (Table 1) with DAPI-stained cells accounting for $>95 \%$ of the total cell counts. This trend was also reflected in the exclusion of the SYTOX Green component of the ViaGram ${ }^{\mathrm{TM}}$ assay, with $>90 \%$ of the bacteria deemed to have intact cell membranes. In addition, ViaGram ${ }^{\mathrm{TM}}$ staining revealed $<1 \%$ of the cells analysed to be Gram positive.

Results obtained with the BacLight ${ }^{\mathrm{TM}}$ kit were not consistent with the other assays. The majority of bacterial cells were observed as being compromised and $<12 \%$ were deemed to have intact cell membranes (as indicated by cells where SYTO 9 fluorescence had not been quenched by PI within the cell). Due to the significantly lower estimate of viable cells and high variability between the filtered and unfiltered treatments these results were not considered for statistical analysis.

\subsubsection{Activity probes}

High intracellular activity was observed with the FISH component of the mVSP protocol. Cells with sufficient numbers of ribosomes to be detected by probe hybridisation when visualised with a Narrow Blue filter set accounted for an average of $80 \%$ of the cells examined, indicating significant bacterial activity and growth (Table 2.1). 
The intracellular reduction of CTC to its red-fluorescing insoluble form was recorded in all samples. Approximately $32 \%$ of the bacterial cells were considered to have an active electron transport system and be undergoing oxidative metabolism (Table 2.1).

There was no statistically significant difference for any assay between samples cultured in the light $\left(5 \mu \mathrm{mol}\right.$ photons $\left.\mathrm{m}^{-2} \mathrm{~s}^{-1}\right)$ or kept in the dark during the incubation period $(P=0.69, \mathrm{n}=3$ for NADS; $P=0.84, \mathrm{n}=3$ for $\mathrm{mVSP} ; P=0.48, \mathrm{n}=3$ for ViaGram $^{\mathrm{TM}}$ and $P=0.70, \mathrm{n}=6$ for CTC). No effect on cell viability or intracellular activity was found in comparing the filtered and unfiltered treatments (presence/absence of microalgae) for any of the four assays $(P=0.81, \mathrm{n}=3$ for NADS; $P=0.28, \mathrm{n}=3$ for $\mathrm{mVSP} ; P=0.51, \mathrm{n}=3$ for $\operatorname{ViaGram}^{\mathrm{TM}}$ and $P=0.99, \mathrm{n}=$ 6 for CTC).

\subsubsection{Cell growth/division}

No in vitro growth (visibly elongated cells) was observed using the DVC assay following the $7 \mathrm{hr}$ period of incubation in any of the antibiotic-spiked samples. A comparison of the total counts of DAPI-stained bacterial cells pre- and postincubation (antibiotic-free samples only) were not significantly different $(P=0.97, \mathrm{n}$ =3) confirming cell division had not occurred during the course of the experiment.

\subsection{Discussion}

Understanding the spatial and temporal dynamics of Antarctic sea-ice and associated biotic communities is fundamental to quantifying the trophodynamics of the Antarctic coastal ecosystem. Evidence that bacteria actively grow in sea-ice dates 
back as recently as the 1980's. Sullivan and Palmisano (1984) observed large and morphologically distinct cells undergoing cell division in fast- ice in McMurdo Sound, implying an active heterotrophic community, while microautoradiographic uptake of radiolabeled compounds such as ${ }^{14} \mathrm{C}$-L-serine, ${ }^{3} \mathrm{H}$-serine, ${ }^{3} \mathrm{H}$-glucose and ${ }^{3} \mathrm{H}$-thymidine confirmed community-level activity in the form of DNA synthesis (Sullivan \& Palmisano 1984, Sullivan et al. 1985).

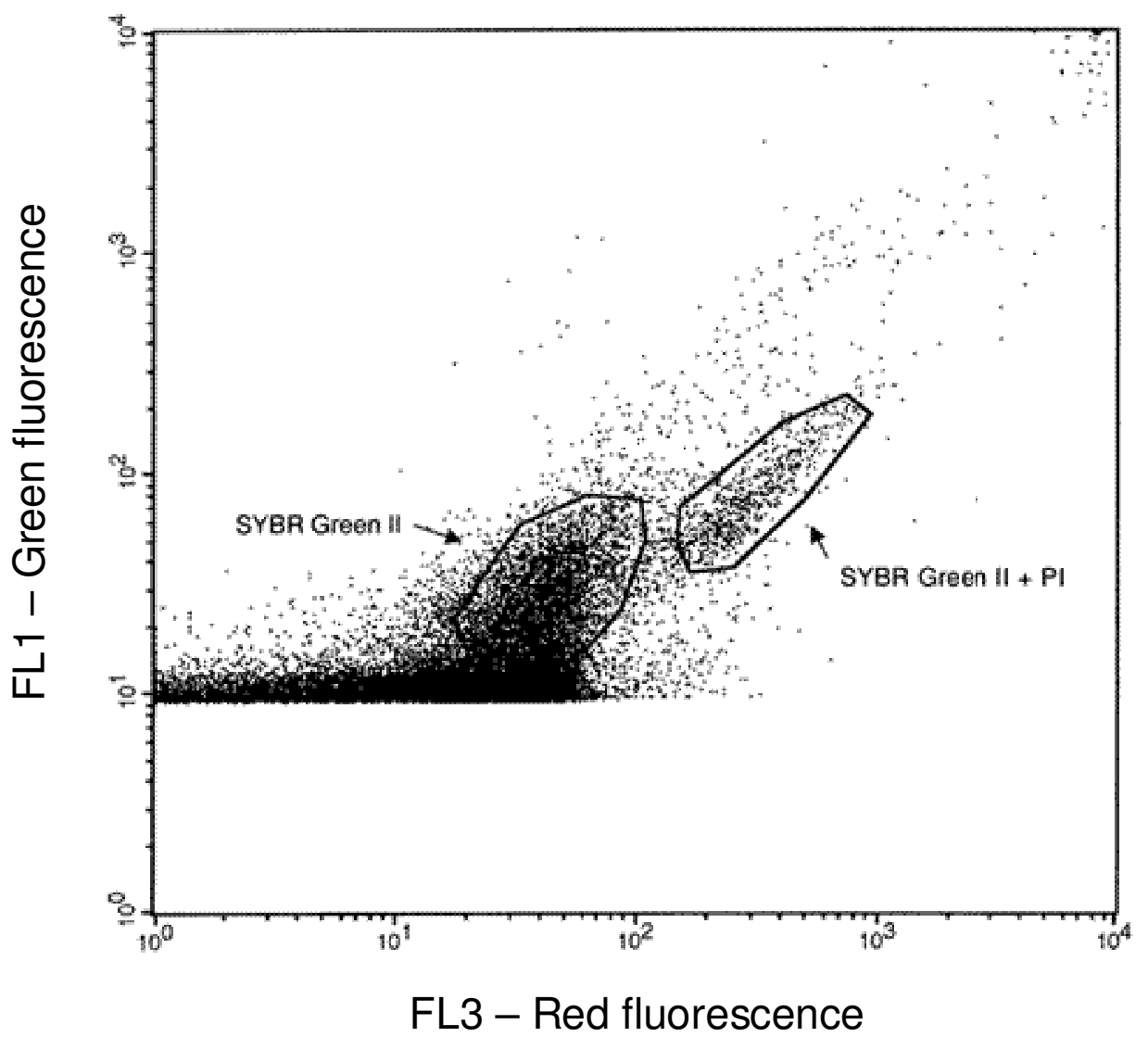

Figure 2.2: Flow cytometric detection of sea-ice bacteria collected from fast-ice at Cape Hallett, Antarctica. Cells were stained with SYBR Green II and PI (NADS) and visualised on bivariate plots of green (FL1) vs. red (FL3) fluorescence. Viable cells are indicated as those stained with SYBR Green II only, while injured cells are those stained with both SYBR Green II + PI. 
Table 2.1: Post-incubation estimates of cell membrane integrity/intracellular activity for Antarctic bottom-ice bacteria collected at Cape Hallett with dark/light $\left(5 \mu \mathrm{mol}\right.$ photons $\left.\mathrm{m}^{-2} \mathrm{~s}^{-1}\right)$ and presence/absence (filtered, unfiltered) of microalgae as treatment variables. Assay abbreviations: NADS (nucleic acid double staining); mVSP (modified vital stain and probe); ViaGram ${ }^{\mathrm{TM}}$ (viability and gram stain) CTC (5-cyano-2,3-ditolyl tetrazolium chloride). Data are means $\pm 1 S E$.

\begin{tabular}{|c|c|c|c|c|c|c|c|}
\hline \multirow[t]{2}{*}{ Assay } & \multirow[t]{2}{*}{ Irradiance } & \multicolumn{4}{|c|}{ Treatment } & & \\
\hline & & Unfiltered & & & Filtered & & \\
\hline \multirow[t]{2}{*}{$\begin{array}{c}\text { NADS } \\
\text { (Cell counts) }\end{array}$} & Dark & $\begin{array}{c}\text { Intact cells } \\
14420 \pm 1577\end{array}$ & $\begin{array}{c}\text { Damaged cells } \\
5917 \pm 98\end{array}$ & $\begin{array}{c}\% \text { intact } \\
71\end{array}$ & $\begin{array}{l}\text { Intact cel/s } \\
2103 \pm 411\end{array}$ & $\begin{array}{c}\text { Damaged cells } \\
848 \pm 56\end{array}$ & $\begin{array}{c}\% \text { intact } \\
71\end{array}$ \\
\hline & $5 \mu \mathrm{mol}$ photons $\mathrm{m}^{-2} \mathrm{~s}^{-1}$ & $13244 \pm 1139$ & $5839 \pm 86$ & 69 & $1871 \pm 302$ & $776 \pm 153$ & 71 \\
\hline MVSP & Dark & $>95 \%$ & & & $>95 \%$ & & \\
\hline (\% intact) & $5 \mu \mathrm{mol}$ photons $\mathrm{m}^{-2} \mathrm{~s}^{-1}$ & $>95 \%$ & & & $>95 \%$ & & \\
\hline \multirow[t]{2}{*}{ (\% probe positive) } & Dark & $79 \pm 5$ & & & $86 \pm 5$ & & \\
\hline & $5 \mu \mathrm{mol}$ photons $\mathrm{m}^{-2} \mathrm{~s}^{-1}$ & $66 \pm 25$ & & & $92 \pm 5$ & & \\
\hline ViaGram $^{\mathrm{TM}}$ & Dark & $95 \pm 5$ & & & $98 \pm 2$ & & \\
\hline (\% intact) & $5 \mu \mathrm{mol}$ photons $\mathrm{m}^{-2} \mathrm{~s}^{-1}$ & $98 \pm 1$ & & & $95 \pm 4$ & & \\
\hline CTC & Dark & $32 \pm 1$ & & & $30 \pm 7$ & & \\
\hline (\% respiring) & $5 \mu \mathrm{mol}$ photons $\mathrm{m}^{-2} \mathrm{~s}^{-1}$ & $32 \pm 3$ & & & $34 \pm 7$ & & \\
\hline
\end{tabular}


Results presented in the current study provide further evidence that bacteria are highly active within the sea-ice matrix during the austral spring. The enhanced resolution provided by single-cell analysis revealed that $32 \%$ of the cells examined were undergoing active respiration (CTC+) (Table 2.1). This is a significantly higher fraction than the 2 to $10 \%$ level of activity typical for most marine systems (Bernard et al. 2000, Bernard et al. 2001, Schumann et al. 2003, Longnecker et al. 2005). Additionally, high ribosomal content was detected in the majority of cells analysed by fluorescence in situ hybridisation and a comparable level of viability was inferred in the fraction of bacterial cells with intact membranes. Although the methods target different physiological characteristics and a consensus among techniques was not necessarily expected, I suggest that the synthesis of information on membrane integrity, rRNA content and respiratory activity confirms sea-ice to be among the most productive microbial habitats.

High single-cell activity in the sea-ice ecosystem reflects the favourable suite of physicochemical traits associated with bacterial growth and development. The total bacterial biomass increases rapidly during the austral summer, particularly in the bottom or congelation layer of fast-ice, where salinity, temperature, substrate, availability of DOM and other nutrient pools results in bacterial carbon concentrations that can be ten times higher than that of the bacterioplankton in the water column below (Sullivan \& Palmisano 1984). Although a novel approach to DAPI staining developed by Junge et al. (2001) now allows the in situ abundance of bacterial cells to be determined in thin sections of ice, melting the ice matrix is still required to examine metabolic activity. The procedure of Ryan et al. (2004) is currently the best method in approximating in situ sea-ice conditions and results in 
minimal changes in temperature during the melting process. However the release of DOM in particular form the ice matrix has been shown to enhance both primary and secondary production (Giesenhagen et al. 1999), and this may have influenced my findings.

Of particular interest is the trophic relationship between bacteria and microalgae and this has historically been inferred by gross correlations between bacterial and algal biomass (see Stewart \& Fritsen 2004 and references therein). However, few physiological experiments have been conducted that include the bacterial component of the sea-ice community (but see Kottmeier \& Sullivan 1988, Nichols et al. 1999). In the present study, restricting the availability of algal photosynthate (DOM) for bacterial uptake by incubating samples in the dark and reducing the volume of algal cells did not restrict bacterial metabolic activity (Table 2.1.) This implies that photosynthate was not a limiting factor for bacterial metabolism during the period of incubation. It is also likely that the process of filtration ruptured algal cells, potentially increasing the availability of DOM in the filtered treatment. Given the observed level of metabolic activity I suggest that the collected samples were saturated with photosynthate and that future experiments will require significantly longer incubation periods to observe changes in bacterial activity.

\subsubsection{Viability staining}

Dual fluorescent-labelling of bacteria to interrogate membrane integrity has become a well-accepted criterion for characterising viable bacterial cells (Grégori et al. 2001, Schumann et al. 2003). Loss of membrane integrity represents significant damage to various functions linked to the plasma membrane and is generally considered 
irreversible in prokaryotes (Joux \& Lebaron 2000). In most marine systems the majority of bacterioplankton have compromised membranes (Choi et al. 1996, Howard-Jones et al. 2002, Davidson et al.2004, but see Schumann et al. 2003) which has led to the notion that a significant fraction of individual cells are not actively engaged in cellular metabolism. With the exception of the BacLight ${ }^{\mathrm{TM}}$ assay, findings for the sea-ice ecosystem revealed high membrane integrity at the time of sampling. The minor variability in the results obtained using NADS and mVSP, are likely to reflect the varying concentrations of PI used in each assay.

The phenanthridinium derivative PI is one of the most common impermeant or 'dead cell stains', but has been used at varying concentrations in the literature (see Davidson et al. 2004). For the viability component of the mVSP we followed the guidelines of Williams et al. (1998) who developed the protocol and suggested staining at $0.2 \mu \mathrm{g} \mathrm{ml}^{-1}$. Given the low return of PI-stained cells $(<1 \%)$ we surveyed the literature before using the NADS protocol and increased the concentration to 15 $\mu \mathrm{g} \mathrm{ml}^{-1}$ (based on Grégori et al. 2001 and Alonso-Sáez et al. 2006). This increase in PI concentration resulted in a larger ( $30 \%$ of the total) population of 'leaky' or compromised cells that stained with both PI and SYBR Green II. Unlike Grégori et al. (2001) we did not generate cytograms with a distinct population of cells stained with PI only (fully compromised/dead). The increased concentration of PI would suggest a more appropriate staining regime for the samples we obtained, but the results illustrate that the abundance of compromised cells can vary greatly with stain concentration. However, samples stored in glycerol can be stained according to the NADS protocol and be effectively analysed by flow cytometry, which as far as we are aware, has not been demonstrated before. Both assays infer high membrane 
integrity and do not require fixation/rapid processing which provides a distinct advantage given the logistical constraints of deep-field Antarctic research.

The low proportion of viable cells reported with the $\mathrm{Bac} \mathrm{Light}^{\mathrm{TM}}$ kit may reflect the dominance of Gram-negative bacteria present in sea. Although the manufacturer suggests the cell permeant component of the BacLight ${ }^{\mathrm{TM}}$ kit (SYTO-9) penetrates a large number of both Gram-negative and Gram-positive bacteria, Langsrud and Sundheim (1996) reported that 30\% of Gram-negative Pseudomonas aeruginosa strains did not accumulate SYTO-9. Staining with the ViaGram ${ }^{\mathrm{TM}}$ kit revealed $<1 \%$ of the cells to be Gram-positive and subsequent genotyping of the Cape Hallet bacterial community confirmed that most species belong to the Proteobacteria and Cytophaga-Flavobacterium-Bacteroides (CFB) groups which are Gram-negative (Simpson 2007). In the only other examination to date of viable bacterioplankton in the Southern Ocean (Davidson et al. 2004), approximately $20 \%$ of cells stained with SYTO-9 which is significantly higher than my findings. However, other authors report the underestimation of total bacterial abundance (both living and dead cells) using BacLight ${ }^{\mathrm{TM}}$ such as Gasol et al. (1999) and Schumann et al. (2003) in studies of the Mediterranean and Baltic seas respectively.

The impermeant nucleic acid component of the $\operatorname{ViaGram}^{\mathrm{TM}}$ kit (SYTOX Green) is a newer product from Molecular Probes that claims to detect both Gram-negative and Gram-positive bacteria with damaged membranes. ViaGram ${ }^{\mathrm{TM}}$ (combined with FISH) has been used successfully by Savichtcheva et al. (2005) to examine Bacteroides spp. in drinking water, but Lebaron et al. (1998) suggest that SYTOX Green may underestimate the fraction of compromised cells due to degradation of target sites following damage to membranes. In the current study, exclusion of SYTOX Green 
was observed in $>90 \%$ of the cells indicating high membrane integrity but we are cautious in drawing conclusions based on this assay alone given the findings of Lebaron et al. (1998). Boulos et al. (1999) determined that fixation of cells prior to enumeration decreased the total and viable counts of some $E$. coli strains. This infers a potential bias in viability estimates for both the $\mathrm{BacLight}^{\mathrm{TM}}$ and ViaGram ${ }^{\mathrm{TM}}$ data given that samples were stored in formalin prior to analysis.

\subsubsection{Activity probes}

During recent years fluorescence in situ hybridisation (FISH) with rRNA-targeted oligonucleotide probes has been successfully applied to a range of freshwater, coastal and offshore marine ecosystems (Pernthaler et al. 2001). In addition to describing bacterial community structure (e.g. domain or group-specific probing), this method is a sensitive measure of cell-specific activity as the threshold signal of FISH is correlated with cellular rRNA content (Pernthaler et al. 2002, Howard-Jones et al. 2002, Junge et al. 2004). In a recent review Bouvier \& del Giorgio (2003) reported the average detection rate of bacterioplankton across a range of aquatic communities to be $56 \%$ using the Bacteria-specific probe EUB338, but with a variance of $5 \%$ to $100 \%$. These differences may reflect variations in the physiological status of bacterial cells, but some authors have highlighted limitations relating to methodological differences such as fluorochrome type, stringency conditions and cell type (see Cottrell \& Kirchman 2000, Smith \& del Giorgio 2003, Bouvier \& del Giorgio 2003). The limited number of studies conducted in the Southern Ocean and polar regions, however, report consistently high trends in bacterial rRNA content. Simon et al. (1999) found a detection rate in Southern Ocean waters that increased from 61 to $96 \%$ between the Polar Front and marginal ice zone while Brinkmeyer et 
al. (2003) reported $~ 95 \%$ of cells in first-year pack ice in the Weddell Sea to be probe-positive which compares well with my estimate of $80 \%$ for the Cape Hallett fast-ice community. Although fewer cells (an average of 60\%) were detected by Junge et al. (2004) in sea-ice sampled during the Arctic winter this may reflect seasonal sampling, and in general FISH detection rates appear to be significantly higher in sea-ice than other systems.

The probe that has been most widely used to assess single-cell activity is 5-cyano2,3-ditolyl tetrazolium chloride (CTC) developed by Rodriguez et al. (1992). This technique has gained wide application in recent years in environmental studies and has been reported to be a simple and effective method of separating active from inactive bacteria, without the need for sophisticated equipment (Créach et al. 2003). Cells that reduce sufficient CTC to be scored as ETS-active are considered to be undergoing oxidative metabolism and capable of growth (Choi et al. 1999). However, the use of CTC remains controversial (Servais et al. 2001, Gasol \& Ariśtequi 2007). Ullrich et al. (1996) have claimed that the stain in fact inhibits metabolism in bacterial cells and underestimates the proportion of active cells in natural aquatic environments. In addition, it is not certain whether all bacterial strains are capable of reducing the compound to its fluorescent form (Choi et al. 1999, Bernas \& Dobrucki 2000). Although some fraction of active cells may be misrepresented by the CTC assay, there is general agreement that this technique is useful to determine the most active cells in a natural population (del Giorgio et al. 1997, Sherr et al. 2001, del Giorgio and Bouvier, 2002, Sieracki et al. 2003, Davidson et al. 2004). CTC-staining of bacteria in seawater has typically ranged from 1 to $10 \%$ (Gasol et al. 1995, Sherr et al. 1999, Sherr et al. 2002, Longnecker et 
al. 2005). To our knowledge CTC has been employed only twice before in polar ecosystems. Jung et al. (2002) found up to $27 \%$ of bacterial cells in Arctic pack-ice during the summer to be undergoing active respiration but interestingly found only 0.5 to $4 \%$ activity during a manipulative experiment in winter (Junge et al. 2004). I present the first application of CTC in Antarctic sea-ice and findings are comparable with those of Junge et al. (2002) in the Arctic summer.

\subsubsection{Can activity/viability assays be used in manipulative experiments?}

Compared with uptake methods, single-cell analysis provides significantly finer resolution in quantifying metabolic activity in Antarctic sea-ice and the results found here will form the basis for future work. Although I agree with Smith and del Giorgio (2003) that a combination of methods is needed to effectively describe community metabolic activity, my results indicate that careful attention be given to which assays are used, and these are likely to differ for each system of interest.

With a general lack of empirical evidence it was considered useful to employ the DVC assay, but it is not surprising that dividing cells were not observed during a 7 hour incubation period given that growth rates for bacteria from environments $\leq 4^{\circ} \mathrm{C}$ are typically in the order of $0.39 \mathrm{~d}^{-1}$ (Rivkin et al. 1996). The findings presented here are considered preliminary given the small sample size, but do confirm sea-ice to be a productive microbial habitat. Additionally, this data provides a useful calibration for future experiments, particularly in addressing factors that influence bacterialalgal linkages. Clearly, there are limitations inherent to each technique, but I favour CTC for single-cell experimental work in the sea-ice system. The main advantage of CTC is that intracellular enzymatic activity responds more quickly than changes to 
cellular structures, and it seems unlikely that other assays can be used to quantify changes in metabolic activity in short-term experiments. Even if the assay targets only the most active bacterial fraction, I suggest that this response may be representative of overall sea-ice community dynamics. In addition, CTC is a relatively easy assay to use in Antarctic field conditions, and flow cytometry provides a rapid and accurate means of sample processing.

\subsection{Literature cited}

Alonso-Sáez L, Gasol JM, Lefort T, Hofer J, Sommaruga R (2006) Effect of natural sunlight on bacterial activity and differential sensitivity of natural bacterioplankton groups in northwestern Mediterranean coastal waters. Applied and Environmental Microbiology 72: 5806-5813.

Azam F, Worden AZ (2004) Microbes, molecules, and marine ecosystems. Science 303: $1622-1624$.

Azam F, Smith DC, Hollibaugh, JT (1991) The role of the microbial loop in Antarctic pelagic ecosystems. Polar Research 10: 239-243.

Bernard L, Schäfer H, Joux F, Courties C, Muyzer G, Lebaron P (2000) Genetic diversity of total, active and culturable marine bacteria in coastal seawater. Aquatic Microbial Ecology 23: 1-11.

Bernard L, Courties C, Duperray C, Schäfer H, Muyzer G, Lebaron, P (2001) A new approach to determine the genetic diversity of viable and active bacteria in aquatic ecosystems. Cytometry 43: 314-321.

Bernas T, Dobrucki JW (2000) The role of plasma membrane in bioreduction of two tetrazolium salts, MTT, and CTC. Archives of Biochemistry and Biophysics 380: 108116.

Boulos L, Prevost M, Barbeau B, Coallier J, Desjardins R (1999) LIVE/DEAD BacLight: application of a new rapid staining method for direct enumeration of viable and total bacteria in drinking water. Journal of Microbiology Methods 31: 77-86.

Bouvier T, del Giorgio PA (2003) Factors influencing the detection of bacterial cells using fluorescence in situ hybridization (FISH): A quantitative review of published reports. FEMS Microbiology and Ecology 44: 3-15.

Brinkmeyer R, Knittel K, Jurgens J, Weyland H, Amann R, Helmke E (2003) Diversity and structure of bacterial communities in Arctic versus Antarctic pack ice. Applied and Environmental Microbiology 69: 6610-6619.

Choi JW, Sherr BF, Sherr EB (1996) Relation between presence-absence of a visible nucleoid and metabolic activity in bacterioplankton cells. Limnology and Oceanography 41: 1161-1168.

Choi JW, Sherr BF, Sherr EB (1999) Dead or alive? A large fraction of ETS-inactive marine bacterioplankton cells, as assessed by reduction of CTC, can become ETS-active with incubation and substrate addition. Aquatic Microbial Ecology 18: 105-115.

Cottrell MT, Kirchman DL (2000) Natural assemblages of marine proteobacteria and members of the Cytophaga-Flavobacter cluster consuming low-and high-molecularweight dissolved organic matter. Applied and Environmental Microbiology 66: 16921697. 
Créach V, Baudoux A-C, Bertu G, Le Rouzic B (2003) Direct estimate of active bacteria: CTC use and limitations. Journal of Microbiology Methods 52: 19-28.

Davidson AT, Thomson PG, Westwood K, van den Enden R (2004) Estimation of bacterioplankton activity in Tasmanian coastal waters and between Tasmania and Antarctica using stains. Aquatic Microbial Ecology 37: 33-45.

del Giorgio PA, Bouvier TC (2002) Linking the physiologic and phyolgenetic successions in free-living bacterial communities along an estuarine salinity gradient. Limnology and Oceanography 37: 471-486.

del Giorgio PA, Prairie YT, Bird DF (1997) Coupling between rates of bacterial production and the abundance of metabolically active bacteria in lakes, enumerated using CTC deduction and flow cytometry. Microbial Ecology 34: 144-154.

Delille D (1996) Biodiversity and function of bacteria in the Southern Ocean. Biodiversity and Conservation 5: 1505-1523.

Garrison DL (1991) Antarctic Sea Ice Biota. American Zoologist 31: 17-33.

Garrison DL, Gibson A, Coale SL, Gowing, MM, Okolodkov YB, Fritsen HF, Jeffries MO (2005) Sea-ice microbial communities in the Ross Sea: autumn and summer biota. Marine Ecology Progress Series 300: 39-52.

Gasol JM, Ariśtequi J (2007) Cytometric evidence reconciling the toxicity and usefulness of CTC as a marker of bacterial activity. Aquatic Microbial Ecology 46: 71-83.

Gasol JM, Zweifel UL, Peters F, Fuhrman JA, Hagstrom A (1999) Significance of size and nucleic acid content heterogeneity as measured by flow cytometry in natural planktonic bacteria. Applied and Environmental Microbiology 65: 4475-4483.

Gasol JM, del Giorgio PA, Massana R, Duarte CM (1995) Active versus inactive bacteria: a size-dependence in a coastal marine plankton community. Marine Ecology Progress Series 128: 91-97.

Giesenhagen HC, Detmer AE, de Wall J, Weber A, Gradinger RR, Jochem, FJ (1999) How are Antarctic planktonic microbial food webs and algal blooms affected by melting of sea ice? Microcosm simulations. Aquatic Microbial Ecology 20: 183-201.

Grégori G, Citterio S, Ghiani A, Labra M, Sgorbati S, Brown S, Denis M (2001) Resolution of viable and membrane-compromised bacteria in freshwater and marine waters based on analytical flow cytometry and nucleic acid double staining. Applied and Environmental Microbiology 67: 662-4670.

Howard-Jones MH, Ballard VD, Allen AE, Frischer ME, Verity PG (2002) Distribution of bacterial biomass and activity in the marginal ice zone of the central Barent's Sea during summer. Journal of Marine Systems 38: 77-91.

Howard-Jones MH, Frischer ME, Verity PG (2001) Determining the physiological status of individual bacterial cells. In: Paul J (ed) Methods in microbiology, vol 30, marine microbiology. Academic Press, p 175-206.

Joux F, Lebaron P (2000) Use of fluorescent probes to assess physiological functions of bacteria at single-cell level. Microbes and Infection 2: 1523-1535.

Junge K, Eicken H, Deming JW (2004) Bacterial activity at -2 to -20 degrees C in Arctic wintertime sea ice. Applied and Environmental Microbiology 70: 550-557.

Junge K, Imhoff F, Staley T, Deming JW (2002) Phylogenetic diversity of numerically important arctic sea-ice bacteria cultured at subzero temperature. Microbial Ecology 43: 315-38.

Junge K, Krembs C, Deming J, Stierle A, Eicken H (2001) A microscopic approach to investigate bacteria under in situ conditions in sea-ice samples. Annals of Glaciology 33: 304-310.

Kottmeier ST, Sullivan CW (1988) Sea ice microbial communities IX. Effects of temperature and salinity on metabolism and growth of autotrophs and heterotrophs. Polar Biology 8: 293-304.

Langsrud S, Sundheim G (1996) Flow cytometry for rapid assessment of viability after exposure to a quaternary ammonium compound. Journal of Applied Bacteriology 81: 411-418. 
Lebaron P, Catala P, Parthuisot N (1998) Effectiveness of SYTOX green stain for bacterial viability assessment. Applied and Environmental Microbiology 64: 2697-2700.

Longnecker K, Sherr BF, Sherr EB (2005) Activity and phylogenetic diversity of bacterial cells with high and low nucleic acid content and electron transport system activity in an upwelling ecosystem. Applied and Environmental Microbiology 71: 7737-7749.

Nichols DS, Greenhill AR, Shadbolt CT, Ross T, McMeekin TA (1999) Physiochemical parameters for growth of the sea ice bacteria Glaciecola punicea ACAM $611^{\mathrm{T}}$ and Geldicacter sp. strain IC158. Applied and Environmental Microbiology 65: 3757-3760.

Pernthaler A, Preston CM, Pernthaler J, DeLong EF, Amann R (2002) Comparison of fluorescently labeled oligonucleotide and polynucleotide probes for the detection of pelagic marine bacteria and archaea. Applied and Environmental Microbiology 68: 661667.

Pernthaler J, Glockner FO, Schonhuber W, Amann R (2001) Fluorescence in situ hybridization (FISH) with rRNA-targeted oligonucleotide probes. In: Paul J (ed) Methods in microbiology, vol 30, marine microbiology. Academic Press, p 207-226.

Rivkin RB, Anderson MR, Lajzerowicz C (1996) Microbial processes in cold oceans .1. Relationship between temperature and bacterial growth rate. Aquatic Microbial Ecology 10: 243-254.

Rodriguez GG, Phipps D, Ishiguro K, Ridgway HF (1992) Use of a Fluorescent Redox Probe for Direct Visualization of Actively Respiring Bacteria. Applied and Environmental Microbiology 58: 1801-1808.

Ryan KG, Ralph P, McMinn A (2004). Acclimation of Antarctic bottom-ice algal communities to lowered salinities during melting. Polar Biology 27: 679-686.

Savichtcheva O, Okayama N, Ito T, Okabe S (2005) Application of a direct fluorescencebased live/dead staining combined with fluorescence in situ hybridization for assessment of survival rate of Bacteroides spp. in drinking water. Biotechnology and Bioengineering 92: 356-363.

Servais P, Agogué H, Courties C, Joux F, Lebaron P (2001) Are the active respiring cells $(\mathrm{CTC}+)$ those responsible for bacterial production in aquatic environments? FEMS Microbiology and Ecology 35: 171-179.

Sherr BF, Sherr E, del Giorgio PA (2001) Enumeration of total and highly active bacteria. In: Paul J (ed) Methods in Microbiology, Vol 30. Marine Microbiology. Academic Press, London, p 129-159.

Sherr BF, del Giorgio P, Sherr EB (1999) Estimating abundance and single-cell characteristics of respiring bacteria via the redox dye CTC. Aquatic Microbial Ecology 18: 117-131.

Sherr EB, Sherr BF, Verity PG (2002) Distribution and relation of total bacteria, active bacteria, bacterivory, and volume of organic detritus in Atlantic continental shelf waters off Cape Hatteras NC, USA. Deep-Sea Research II 49: 4571-4585.

Shumann R, Schiewer U, Karsten U, Rieling T (2003) Viability of bacteria from different aquatic habitats. II. Cellular fluorescent markers for membrane integrity and metabolic activity. Aquatic Microbial Ecology 32: 137-150.

Sieracki ME, Cucci RL, Nicinski J (1999) Flow Cytometric Analysis of 5-Cyano-2,3-Ditolyl Tetrazolium Chloride Activity of Marine Bacterioplankton in Dilution Cultures. Applied and Environmental Microbiology 65: 2409-2417.

Simon M, Glockner FO, Amann R (1999) Different community structure and temperature optima of heterotrophic picoplankton in various regions of the Southern Ocean. Aquatic Microbial Ecology 18: 275-284.

Simpson A (2007) Genotyping microbial life forms in Antarctic sea ice. MSc dissertation, Victoria University of Wellington, Wellington, New Zealand

Smith EM, del Giorgio PA (2003) Low fractions of active bacteria in natural aquatic communities? Aquatic Microbial Ecology 31: 203-208.

Stewart FJ, Fritsen CH (2004) Bacteria-algae relationships in Antarctic sea ice. Antarctic Science 16: 143-156. 
Sullivan CW, Palmisano AC (1984) Sea ice microbial communities: Distribution, abundance, and diversity of ice bacteria in McMurdo Sound, Antarctica, in 1980. Applied and Environmental Microbiology 47: 788-795.

Sullivan CW, Palmisano AC, Kottmeier S, McGrath Grossi S, Moe R (1985) The influence of light on growth and development of the sea ice microbial community in McMurdo Sound. In: Siegfried WR, Condy PR (eds) Antarctic nutrient cycles and food webs. Springer-Verlag, Berlin, $\mathrm{p}$ 78-83.

Ullrich S, Karrasch B, Hoppe H-G., Jeskulke K, Mehrens M (1996) Toxic effects on bacterial metabolism of the redox dye 5-cyano-2,3-ditolyl tetrazolium chloride. Applied and Environmental Microbiology 62: 4587-4593.

Williams SC, Hong Y, Danavall DCA, Howard-Jones MH, Gibson D, Frischer ME, Verity PG (1998) Distinguishing between living and nonliving bacteria: evaluation of the vital stain propidium iodide and its combined use with molecular probes in aquatic samples. Journal of Microbiology Methods 32: 225-236. 


\section{CHAPTER 3}

Melting moments: low salinity and high UV-B radiation reduce single-cell activity in Antarctic sea-ice bacteria

\subsection{Abstract}

Although Antarctic sea-ice bacteria are known to exhibit high levels of metabolic activity, few studies have examined bacterial adaptation to the physicochemical extremes of the sea-ice matrix. The ability of bacteria to cope with transitional saline and irradiance levels may influence microbial loop dynamics within the ice and determine the capacity of ice-derived bacteria to act as 'seed populations' that initiate ice edge blooms. In this study a series of experiments simulating the sea-ice cycle were conducted by exposing microbes from the bottom or congelation layer of annual fast-ice to saline and irradiance regimes (both PAR and UV-B) associated with the annual freeze/thaw of the ice matrix. PAR was included as a treatment variable in order to examine the response of bacteria to algal-derived photosynthate. Bacterial metabolic activity was quantified using the cell-specific assay 5-cyano-2,3-ditolyl tetrazolium chloride (CTC), and findings were calibrated against incorporation rates of $\left[{ }^{3} \mathrm{H}\right]$ leucine. Single-cell activity was highest in treatments maintained at 51\%o and 69\%o salinity, while at $21 \% \circ$ and $8 \%$ metabolic activity was reduced. Covariation between light and salinity variables indicated only a weak interaction between bacteria and microalgae, but in manipulated treatments where photosynthate was restricted, bacterial activity was 
significantly reduced. Sea-ice bacteria responded to UV-B radiation in a dosedependant manner. Significant inhibition to intracellular activity was observed after a total dose of $12.5 \mathrm{~kJ} \mathrm{~m}^{-2}$ over $12 \mathrm{hr}$, while in treatments exposed to a level of UV-B more typical of the austral spring $\left(25 \mathrm{~kJ} \mathrm{~m}^{-2}\right),<2 \%$ of the bacterial cells scored as CTC + . These results suggest that the release of bacteria into the hyposaline meltwater lens at the ice edge during summer combined with rapid exposure to increased UV-B radiation causes more metabolic stress than incorporation into the ice matrix during the process of freezing.

\subsection{Introduction}

Although a transient phenomenon, sea-ice is a predominant feature of polar oceans and exerts a unique influence on Antarctic marine ecosystems (Garrison 1991, Ackley \& Sullivan 1994). The presence of land-fast ice strongly affects the physical and biological processes associated with the Antarctic coastal ecosystem, particularly in modulating the exchange of heat and moisture between the atmosphere and ocean and restricting the penetration of solar radiation (Delille et al. 1992, Legendre et al.1992). For microbial communities, the ice matrix represents a harsh physicochemical environment and productivity reflects a complex relationship between ice dynamics, distribution of organic and inorganic nutrients, PAR and UV radiation, and the structure of the sea-ice biota - all of which modifies the cycling of energy through the community (Arrigo \& Sullivan 1992, Vaqué et al. 2002, Stewart \& Sullivan 2004). As such, the quantitative importance of bacterial production is difficult to assess (Kottmeier \& Sullivan 1988), but it is likely that bacteria released from melting ice contribute to microbial blooms at the 
marginal ice zone and participate in a microbial loop within the ice, which may in turn support higher trophic levels (Grossi et al. 1984, Azam et al. 1991, Giesenhagen et al. 1999, Delille et al 2002, Garrison et al. 2005).

Understanding how the in situ activity of bacterial populations varies in space and time remains a major question in microbial ecology, particularly as cell metabolic status determines the contribution of bacteria to respiration, remineralisation and trophic interactions (Davidson et al. 2004). Historically, ice-derived bacteria have been examined by techniques that measure community level production such as the incorporation of $\left[{ }^{3} \mathrm{H}\right]$ leucine and $\left[{ }^{3} \mathrm{H}\right]$ thymidine (Kottmeier et al. 1987, Kottmeier \& Sullivan 1988, Cota et al. 1990), but in recognition of the complexity of microbial structure and function, a variety of methods can now assess the physiological status of individual bacterial cells (see Schumann et al. 2003, Davidson et al. 2004). Cell-specific respiration, as measured by the reduction of 5-cyano-2,3-ditolyl tetrazolium chloride (CTC), has gained wide application in environmental studies and is useful in quantifying viable cells that are actively involved in biomass production and ecosystem metabolism (del Giorgio et al. 1997, Sherr et al. 2001, Davidson et al. 2004, Longnecker et al. 2005, Gasol \& Ariśtequi 2007, Martin et al. 2008). While the term 'active' can be thought to encompass a continuum of states and that CTC may target only the most active bacterial fraction, this response is likely to represent overall community dynamics and is considered useful in quantifying the single-cell response in manipulative experiments (Martin et al. 2008). 
Although sea-ice bacteria are known to exhibit high levels of metabolic activity, few authors have examined adaptation to the physicochemical extremes of the sea-ice habitat (but see Kottmeier \& Sullivan 1988, Nichols et al. 1999, Nichols et al. 2000, Kaartokallio et al. 2005). This is in contrast to sea-ice algae, where considerable emphasis has been placed on understanding the composition, physiology, and ecology of the pennate diatoms that dominate fast-ice community assemblages. In particular, the application of pulse amplitude modulation (PAM) fluorometry has provided a unique insight into the intracellular stress response of microalgal taxa to a range of experimental stimuli including light, temperature, salinity and UV radiation (eg. Kühl et al. 2001, McMinn et al. 2003, Ryan et al. 2004, Ralph et al. 2005). For example, Ralph et al. (2007) have recently shown that the release of microalgae into the hyposaline meltwater lens at the ice edge during summer causes more physiological stress to microalgae than incorporation into the ice matrix during the freezing process. The ability of Antarctic sea- ice bacteria to cope with transitional saline and irradiance levels associated with ice melt is not known, but may determine their capacity to act as 'seed populations' that initiate ice edge blooms.

In this study I expose microbes from the bottom (congelation layer) of annual fast-ice to irradiance and saline regimes that are similar to those of the annual freeze/thaw of the ice matrix. I adopt a single-cell experimental approach to examine the stress response of bacteria to salinity and calibrate results obtained using the CTC assay with a community level estimate of activity $\left(\left[{ }^{3} \mathrm{H}\right]\right.$ leucine). I include visible light (PAR) as a treatment variable in the simulation to determine whether bacterial activity is influenced by dissolved organic matter (DOM) in the form of algal-derived photosynthate. The 
assimilation of DOM is a core process in the microbial loop hypothesis, but remains equivocal in sea-ice due to the high spatial and temporal variability of the microbial community. Finally, I quantify the metabolic response of bottom-ice bacteria to the rapid change in exposure to UV-B radiation that occurs during ice melt.

\subsection{Materials and methods}

\subsubsection{Sample collection}

Sea-ice bacteria and microalgae were collected in the austral spring of 2006 and 2007 from annual fast-ice in the vicinity of Gondwana Station $\left(74^{\circ} 38^{\prime} \mathrm{S}, 164^{\circ} 12^{\prime} \mathrm{E}\right)$. Holes were drilled to within $300 \mathrm{~mm}$ of the ice/seawater interface with a powered ice auger (Jiffy, USA) and cores (300 mm long, $130 \mathrm{~mm}$ diameter) were extracted from the bottom of each profile using a Kovaks (Kovaks, USA) ice corer. To prevent light shock, all operations were performed under a black sheet and each core was transported in a black plastic tube. Bacterial and algal cells were obtained by cutting and then melting the bottom 50-100 mm of each core in a sterile container over a period of $12 \mathrm{hr}$ under low light $\left(<1 \mu \mathrm{mol}\right.$ photons $\left.\mathrm{m}^{-2} \mathrm{~s}^{-1}\right)$ in three times the quantity of $0.22 \mu \mathrm{m}$-filtered seawater $\left(35 \%,-1.8^{\circ} \mathrm{C}\right)\left(\right.$ Ryan et al. 2004). Bacterial and algal cells remained at $-1.8^{\circ} \mathrm{C}$ during this time period due to the temperature equilibrium maintained by the melting process.

\subsubsection{Leucine incorporation rates}

Incorporation rates of tritiated leucine by bottom-ice bacteria were assayed following the protocol of Kirchman (2001). Triplicate $12 \mathrm{ml}$ samples were prepared from a melted ice core to examine leucine uptake at $0 \mathrm{hr}$ (immediately following ice melt) and $48 \mathrm{hr}$ at 
three saline concentrations $(10 \%$, 33\%o and 54\%o). Equal cell densities were maintained for each treatment and the saline concentration was adjusted $(0.22 \mu \mathrm{m}$-filtered brine or freshwater) over an hour to prevent saline shock for the $10 \%$ and $54 \%$ salinity treatments. A control group was also included by adding trichloroacetic acid (TCA) to three samples at a final concentration of $1 \%$ to kill all cells. Tritiated leucine (Amersham/GE Healthcare, UK; specific activity of $69.0 \mathrm{Ci} / \mathrm{mmol}$ ) was subsequently added to each sample at a final concentration of $20 \mathrm{nM}$. An appropriate incubation time was determined empirically and found to be $3 \mathrm{hrs}$ (see Appendix 1). Incubations were performed in a water bath maintained at $-1.8^{\circ} \mathrm{C}$. An ethylene glycol: water (1:4) mix was used to provide subzero temperatures, and a heater stirrer was used to maintain the incubator to within $\pm 0.2^{\circ} \mathrm{C}$. After incubation, each sample was filtered onto a $0.22 \mu \mathrm{m}$ mixed cellulose esters filter (Millipore, USA) under minimal vacuum $(<200 \mathrm{~mm} \mathrm{Hg}$ ), rinsed twice with $3 \mathrm{ml}$ of ice-cold TCA and twice with $3 \mathrm{ml}$ of ice-cold $80 \%$ ethanol. The filters were placed in $7 \mathrm{ml}$ scintillation vials and returned to New Zealand. Each filter was subsequently dissolved with $0.5 \mathrm{ml}$ ethyl acetate prior to the addition of $5 \mathrm{ml}$ of Ultima-Gold scintillation cocktail (Perkin-Elmer, USA). Activity was measured using a Wallac 1141 (Perkin-Elmer, USA) liquid scintillation counter.

\subsubsection{Effect of light and salinity on bottom-ice bacteria}

The combined effect of salinity and incubation irradiance on single-cell metabolic activity was examined using bacteria and microalgae collected from bottom-ice in the vicinity of Gondwana Station in 2006. Five saline treatments (8\%o, 21\%o, 32\%o, 51\%o and $69 \%$ ) with equal cell densities were prepared over an hour by adding aliquots of seawater and brine or freshwater (all filtered to $0.22 \mu \mathrm{m}$ ) to aliquots of the bottom-ice 
stock solution. In addition, the effects of sample filtration and inhibition of microalgal photosynthesis were examined for the $32 \%$ o saline treatment. To remove the majority of the microalgal cells for the filtered treatment, approximately one third of the stock solution was passed through a net (approximate pore size of $50 \mu \mathrm{m}$ ) followed by vacuum filtration with a $3 \mu \mathrm{m}$ filter (Millipore, USA). For the inhibition treatment, 3-(3,4dichlorophenyl)-1,1-dimethylurea (DCMU, Sigma, USA) was added at a final concentration of $10^{-6} \mathrm{M}$. An array of halogen bulbs was used to provide three light treatments $\left(6.5,76.5\right.$ and $262 \mu \mathrm{mol}$ photons $\left.\mathrm{m}^{-2} \mathrm{~s}^{-1}\right)$. A dark treatment was also included. Samples $(900 \mu \mathrm{l})$ were prepared in $1 \mathrm{ml}$ Eppendorf tubes and incubated in the water bath at $-1.8^{\circ} \mathrm{C}$ for $48 \mathrm{hr}(\mathrm{n}=4$ for each light and salinity treatment; $\mathrm{n}=4$ for filtered and DCMU treatments).

Intracellular activity was examined using 5-cyano-2,3-ditolyl tetrazolium chloride (CTC, Polysciences Inc., USA). Each sample was spiked with 5 mM CTC (final concentration) and incubated in the water bath $\left(-1.8 \pm 0.2^{\circ} \mathrm{C}\right)$ for $3 \mathrm{hr}$ in the dark. Three blank samples consisting of $0.22 \mu \mathrm{m}$-filtered double distilled water and CTC were incubated under the same conditions described above to control for non-specific signals (i.e. CTC precipitate). Cellular synthesis was terminated with the addition of $50 \mu \mathrm{l}$ of $0.22 \mu \mathrm{m}$-filtered formalin (5\% final concentration) and all samples were immediately frozen in liquid nitrogen. CTC-treated samples were transported at $-80^{\circ} \mathrm{C}$ and kept frozen for analysis in New Zealand. Enumeration of CTC+ and total bacterial cells was performed using a BD Biosciences FACScan flow cytometer equipped with a $15 \mathrm{~mW}$, $488 \mathrm{~nm}$, air-cooled argon ion laser and standard filter set-up. Initial instrument 
calibration was performed using FACScomp software in conjunction with CaliBRITE reference beads (Becton Dickinson, USA). TruCount beads (BD Biosciences) were added to each sample in order to accurately calculate the volume of sample analysed. Bacterial data were typically collected for 2 min (acquisition of 200 TruCount beads) and CTC+ positive cells were identified from bivariate plots of red (FL3) vs. orange (FL2) fluorescence. Total bacterial counts were determined by re-running each sample following a 10 min incubation with SYBR Green II (Molecular Probes, USA) and examining bivariate plots of green (FL1) fluorescence vs. SSC (Side Scatter).

\subsubsection{Effect of UV radiation on bottom-ice bacteria}

The effect of UV-B (280-320 nm) on single-cell metabolic activity was examined in bottom-ice bacteria collected at Gondwana Station in 2006 and 2007. Four ice cores were collected using the techniques described above and two blocks with dimensions 60 x 50 x $15 \mathrm{~mm}$ were cut from the bottom of each core. The 8 blocks of ice were then assigned at random to incubation boxes containing a small volume of $0.22 \mu \mathrm{m}$-filtered seawater and allowed to slowly melt over a period of $12 \mathrm{hr}$. Incubations were performed in a water bath $\left(-1.8 \pm 0.2^{\circ} \mathrm{C}\right)$ with an overhead halogen array providing photosynthetically active radiation (PAR) at $30 \mu \mathrm{mol}$ photons $\mathrm{m}^{-2} \mathrm{~s}^{-1}$. In addition to the halogen bulbs, a UV lamp was suspended $300 \mathrm{~mm}$ above the water bath. The two sides of the water bath were separated by a screen, and the level of UV-B emission was adjusted using neutral density filters to provide UV treatment at two levels: 1.2 and 6.2 $\mathrm{kJ} \mathrm{m}^{-2}$. Following the $12 \mathrm{hr}$ exposure period, $900 \mu \mathrm{l}$ of each melted block was assayed using the CTC protocol described above. In 2007, this experiment was repeated with 
increased UV-B treatment levels $\left(12.5\right.$ and $\left.25 \mathrm{~kJ} \mathrm{~m}^{-2}\right)$ and a series of controls were used to measure intracellular activity prior to UV-B exposure.

\subsubsection{Statistical analysis}

Data were analysed using SYSTAT (Version 12.0, SPSS). Where necessary data were $\log$ transformed to meet the assumptions of normality and equal variance. Student's $t$ tests were used to compare rates of leucine incorporation between time points and oneway ANOVA was used to compare salinity treatments within each time point. The influence of salinity and incubation irradiance on single-cell activity was analysed using two-way ANOVA and the effect of UV-B radiation was analysed with one-way ANOVA. Tukey's post hoc test was used to define significant differences.

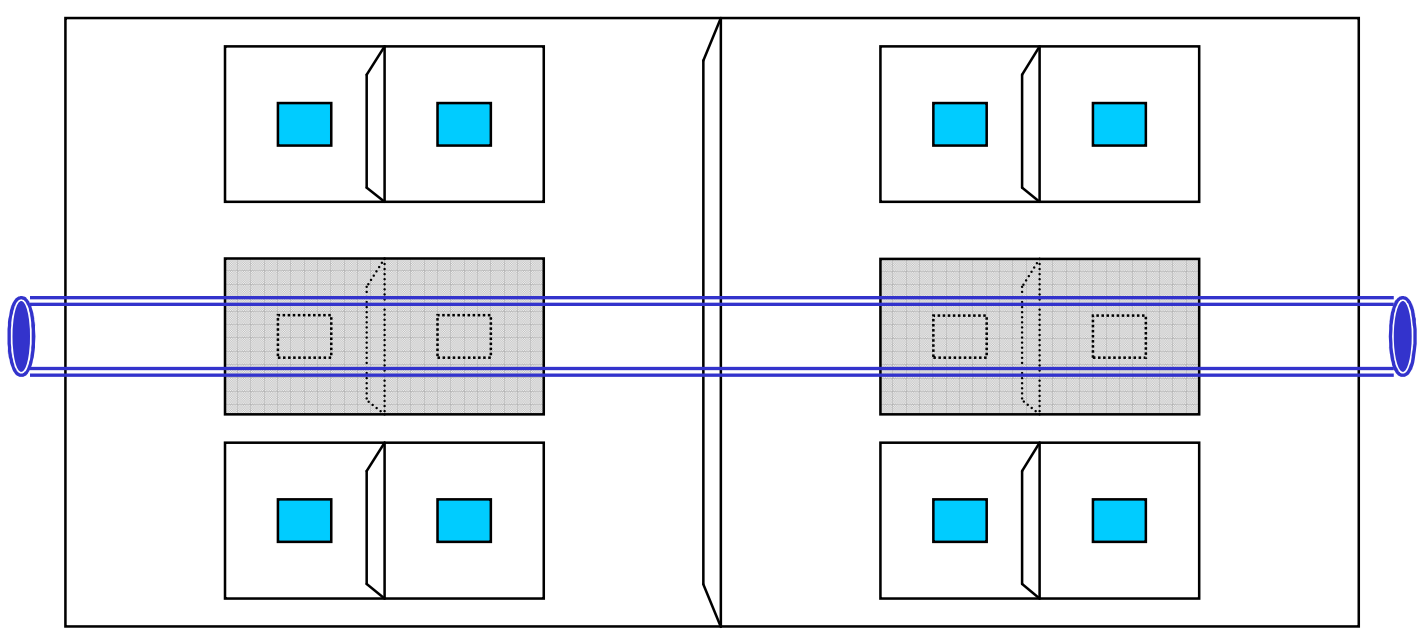

Figure 3.1: Schematic of UV-B experiment. 


\subsection{Results}

\subsubsection{Leucine incorporation by bottom-ice bacteria}

Estimates of sea-ice heterotrophic production (protein biosynthesis) from the uptake of $\left[{ }^{3} \mathrm{H}\right]$ leucine varied between 8.2 and 1048 picomoles $\mathrm{l}^{-1} \mathrm{~h}^{-1}$. Production after a $48 \mathrm{hr}$ period of incubation was significantly higher than the time zero or post-melt estimate for each saline treatment $(10 \%: t=-4.54, \mathrm{df}=2, P=0.045 ; 33 \%$ : $t=-4.69, \mathrm{df}=2, P=$ $0.043 ; 55 \%: t=-5.43, \mathrm{df}=2, P=0.032)$. There was no difference between the three saline treatments at time zero $(F=2.536, \mathrm{df}=2, P=0.159)$, but after $48 \mathrm{hr}$ the uptake of $\left[{ }^{3} \mathrm{H}\right]$ leucine by bacteria incubated at $10 \%$ was significantly lower than the $33 \%$ and 55\%o treatments $(F=36.752, \mathrm{df}=2, P=<0.001)($ Figure 3.2).

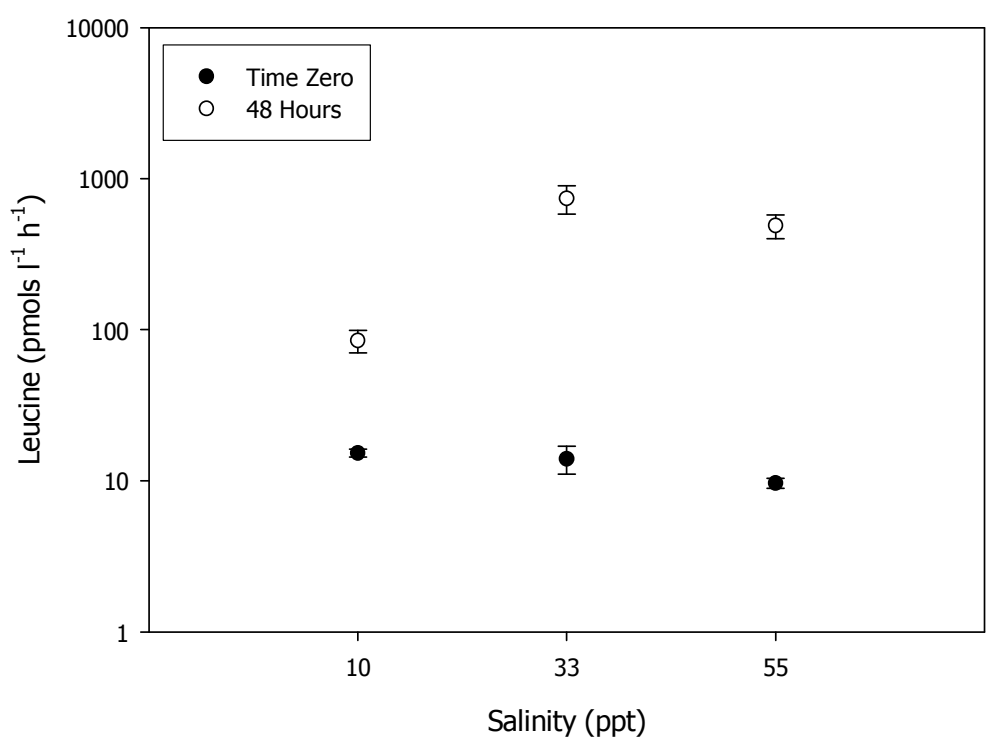

Figure 3.2: Time point estimates (time zero or post ice-melt and $48 \mathrm{hr}$ ) of ${ }^{3} \mathrm{H}$ leucine incorporation by bottom-ice bacteria incubated at three saline concentrations. Data are means $\pm 1 \mathrm{SE}$. 


\subsubsection{Single-cell response of bottom-ice bacteria to light and salinity}

A high level of single-cell metabolic activity was recorded in sea-ice bacteria following exposure to a varying light and saline regime. The percentage of cells undergoing oxidative respiration $(\mathrm{CTC}+)$ varied between $29-85 \%$. There was no significant interaction between light and saline treatments $(F=1.787, \mathrm{df}=12, P=0.072)$, however the effect of salinity on respiration in bottom-ice bacteria was highly significant $(F=$ 9.787, $\mathrm{df}=4, P=<0.001)$. Metabolic activity in cells exposed to $8 \%$ o was significantly lower than all other saline treatments, while single-cell activity was significantly higher at $51 \%$ compared to the $21 \%$ and $32 \%$ saline concentrations (post-hoc Tukey test of all pairwise comparisons)(Figure 3.3).

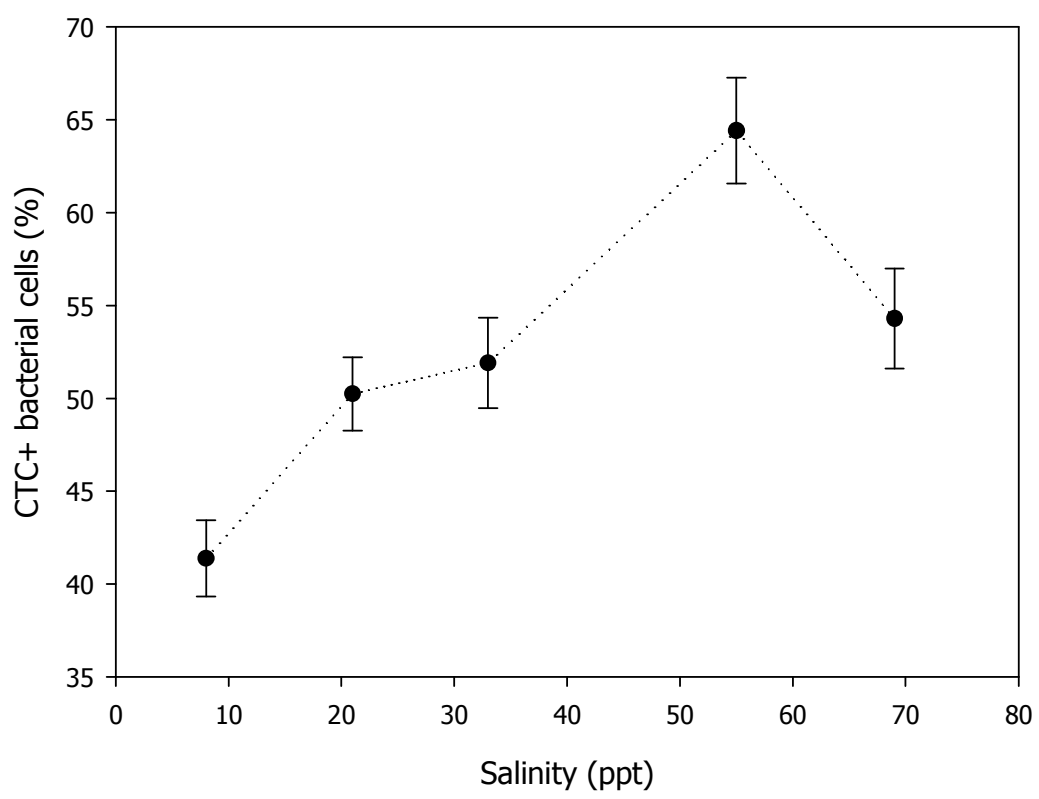

Figure 3.3: Single-cell metabolic activity (CTC+ cells) of bottom-ice bacteria exposed to 5 saline concentrations for $48 \mathrm{hr}$. Data are means $\pm 1 \mathrm{SE}$. 
A significant interaction was found between treatment (filtered, unfiltered and DCMU) and incubation irradiance for cells incubated at the saline concentration of $32 \%$ o $(F=$ 7.177, $d f=6, P=<0.001)($ Figure 3.4). The percentage of CTC + cells varied between 8 69\%. In general, an increase in the percentage of active bacteria in the filtered treatment was coupled with increasing irradiance, while in the unfiltered treatment metabolic activity increased and then declined at $262 \mu \mathrm{mol}$ photons $\mathrm{m}^{-2} \mathrm{~s}^{-1}$. For the samples spiked with DCMU, incubation irradiance had no effect on the percentage of CTC+ cells. In comparison to the unfiltered treatment, filtration and the addition of DCMU both reduced single-cell activity after $48 \mathrm{hr}$. DCMU-treated samples were significantly different at 77.5 and $262 \mu \mathrm{mol}$ photons $\mathrm{m}^{-2} \mathrm{~s}^{-1}$ while the filtered samples differed at 0 and $77.5 \mu \mathrm{mol}$ photons $\mathrm{m}^{-2} \mathrm{~s}^{-1}$ when compared to the unfiltered samples. There was no statistically significant difference between the DCMU and filtered treatments (post hoc Tukey test of all pairwise comparisons).

\subsubsection{Single-cell response of bottom-ice bacteria to UV-B exposure}

Bottom-ice bacteria responded to UV-B radiation in a dose-dependent manner. Data from 2006 and 2007 were analysed separately, but are shown together in Figure 3.5. In 2006 approximately $12 \%$ of the bacteria were CTC+ but there was no significant difference in activity after $12 \mathrm{hr}$ of exposure to UV-B irradiances of 1.2 or $6.2 \mathrm{~kJ} \mathrm{~m}^{-2}$ ( $F$ $=0.265, \mathrm{df}=1, P=0.625)$. Increasing UV-B treatment levels in 2007 to 12.5 and $25 \mathrm{~kJ}$ $\mathrm{m}^{-2}$ respectively resulted in a significant difference in metabolic activity between the pre-exposed controls and bacterial cells exposed to UV-B $(F=10.204, \mathrm{df}=2, P=$ 0.005). Samples exposed to $25 \mathrm{~kJ} \mathrm{~m}^{-2}(1 \% \mathrm{CTC}+)$ were significantly less active than 
those exposed to $12.5 \mathrm{~kJ} \mathrm{~m}^{-2}$ ( $8 \% \mathrm{CTC}+$ ), while the highest UV-B treatment was

significantly different to the pre-exposed control group (18\% CTC + ) as determined by a post-hoc Tukey test.

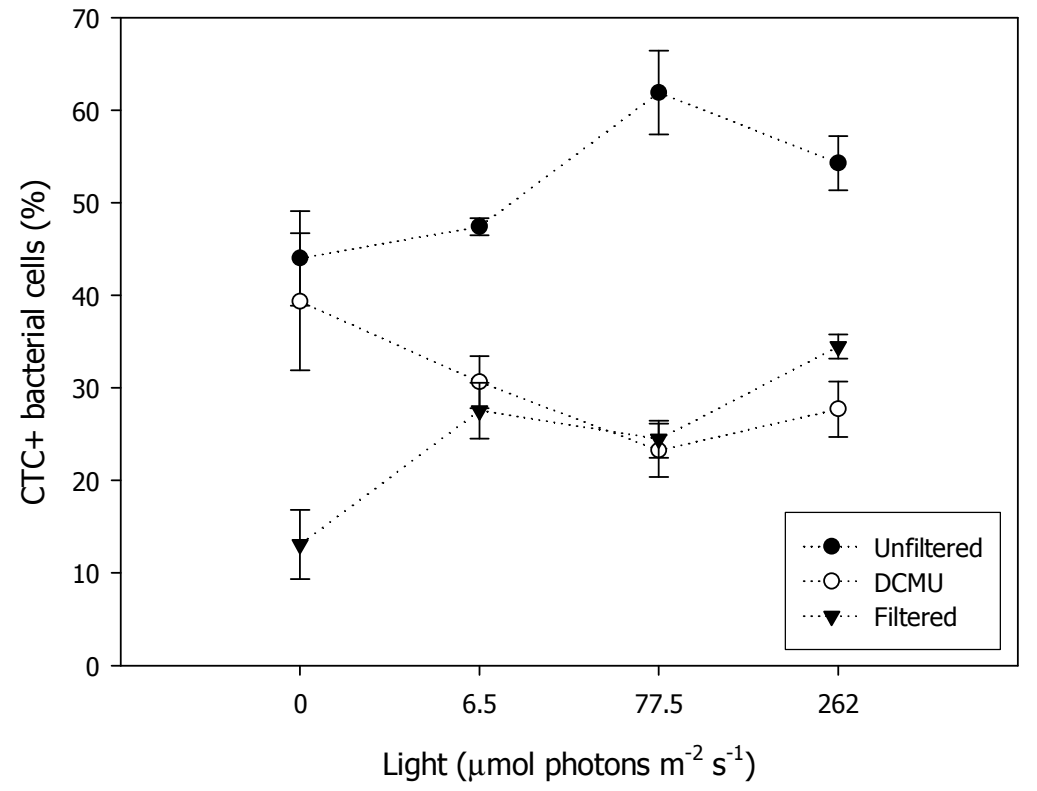

Figure 3.4: Single-cell metabolic activity (CTC+ cells) of bottom-ice bacteria incubated in the dark and at 3 levels of irradiance for $48 \mathrm{hr}$. Salinity $=32 \%$. Additional treatment variables are unfiltered: no post-melt alteration; filtered: removal of cells $>3.0 \mu \mathrm{m}$; DCMU: addition of 3-(3,4-dichlorophenyl)-1,1-dimethylurea. Data are means $\pm 1 \mathrm{SE}$. 


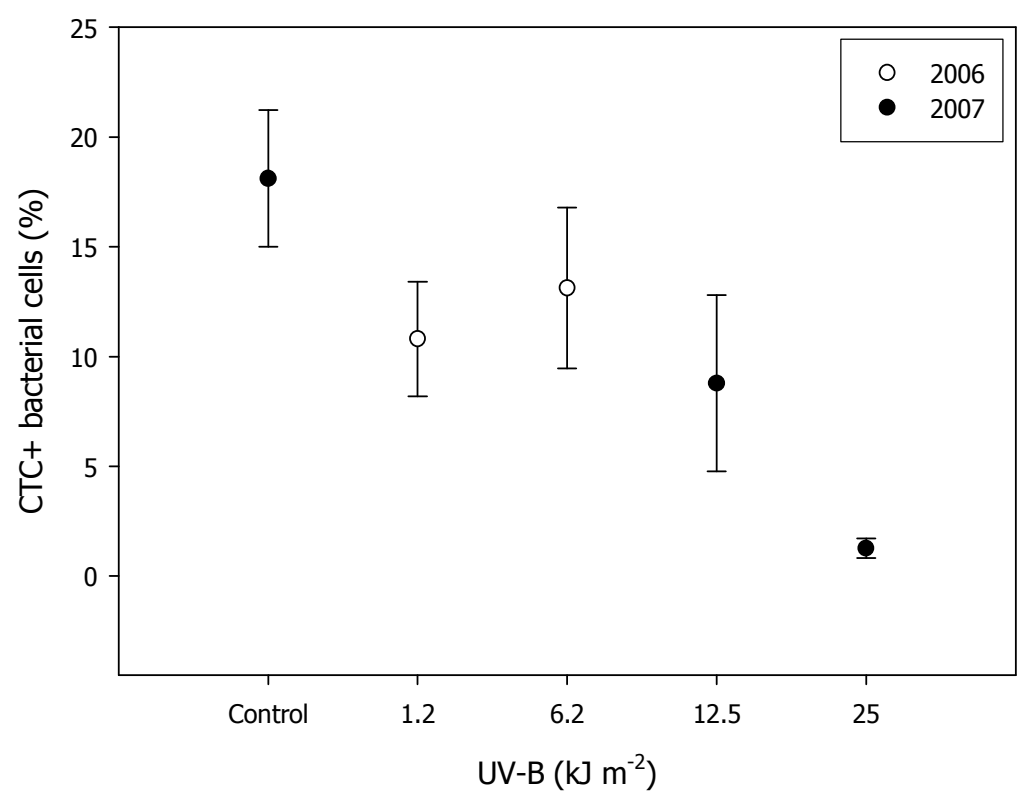

Figure 3.5: Single-cell metabolic response (CTC+ cells) of bottom-ice bacteria exposed to various levels of UV-B radiation (280-320 nm integrated dose) during $12 \mathrm{hr}$ icemelt. Data are means $\pm 1 \mathrm{SE}$.

\subsection{Discussion}

Despite the distinct physiochemical gradients that characterise the sea-ice habitat, bacteria present in the bottom, or congelation layer, of fast-ice exhibit high levels of metabolic activity (Martin et al. 2008). During the austral spring, total bacterial biomass increases rapidly in this region of the ice and can be ten times that of the bacterioplankton in the water column below (Sullivan \& Palmisano 1984). The stimuli for this period of intense productivity include favourable saline and temperature regimes, suitable substrates and the availability of DOM and other nutrient pools. Examining the response of this community to experimental changes in salinity and irradiance regimes is an ecologically relevant way of establishing the response of 
bacterial cells to processes associated with annual ice dynamics, particularly the rapid dissolution of the sea-ice matrix.

Like Falcioni et al. (2008) and Morán et al. (2009), I observed a positive correlation between estimates of $\left[{ }^{3} \mathrm{H}\right]$ leucine incorporation and CTC + bacterial cells (Figure 3.2, Figure 3.3). The concentration of leucine incorporated after $48 \mathrm{hr}$ provides a useful validation for the single-cell estimates that are significantly greater than the $2-10 \%$ that is typical for most marine systems. Additionally, the difference in leucine incorporation between the post-melt and $48 \mathrm{hr}$ incubation periods highlights a response to salinity that is time-dependant rather than an osmotic shock response following initial exposure to altered saline concentrations (Figure 3.2). One of the few studies examining the effect of salinity on bacterial metabolism was that conducted by Kottmeier and Sullivan (1988) with samples of sea-ice from McMurdo Sound in the Ross Sea. For both thymidine and uridine substrates, these authors recorded maximum incorporation at salinities from $20 \%$ o to $30 \%$ o with secondary peaks from $50 \%$ o to $70 \%$ o. The $48 \mathrm{hr}$ incorporation rates of $\left[{ }^{3} \mathrm{H}\right]$ leucine described in the present study essentially supports these findings, but the inclusion of the preliminary post-melt data provides a useful addition in quantifying the community-level response time with respect to ice melt and the increased availability of DOM.

At the single-cell level of resolution, the post-incubation estimate of active cells (CTC+) was high for each saline treatment $(>40 \%)$, but with a notable reduction at $8 \%$ (Figure 3.3). Like Nichols et al. (1999) who demonstrated an upper and lower salinity threshold with respect to the generation time of isolated cultures of sea-ice bacteria, I show that 
the in situ bacterial community exhibits a similar dynamic. The highest levels of singlecell activity were observed at saline concentrations that simulate sea-ice formation (51\%o and $69 \%$ ) which is not unexpected given that strong selection processes are known to favour psychrophilic bacteria following the initial freeze (Thomas \& Dieckmann 2002). In addition to maintaining growth at sub-zero temperatures, these species can produce salt-tolerant enzymes that are thought to confer an adaptive advantage to a range of saline concentrations (Nichols et al. 1999). Although not statistically significant, activity appeared to peak at $51 \%$ and begin to decline at $69 \%$. Given the high fraction of CTC+ cells in both these treatments, cell viability is likely maintained at saline concentrations exceeding 69\%, but the efficiency of intracellular processes is potentially reduced. However, the extent to which physicochemical variables stratify the distribution of bacteria within the ice is not known, and the psychrophiles that accumulate in the congelation layer may not favour, or be adaptable to, the upper-middle region of the ice profile where microbial communities can be exposed to salinities as high as $150 \%$ o (Junge et al. 2004).

In contrast to ice formation and high saline exposure, ice melt and lowered ambient salinity imposes greater stress on bacterial metabolism. A reduction in the activity of bacteria during the transition from sea-ice to the hyposaline lenses (represented by the $21 \%$ and $8 \%$ o treatments) that form at the receding ice edge could potentially limit longterm cell survival and involvement of ice-derived bacteria in bloom events. While protein synthesis was significantly reduced at $8 \%$ (Figure 3.2), cellular respiration following the relatively rapid $(1 \mathrm{hr})$ reduction in salinity was maintained in approximately $50 \%$ of the cells (Figure 3.3). This percentage of active bacteria infers a 
relatively high tolerance to low saline conditions and further salinity-based stress during the subsequent mixing and stabilisation of the water column is unlikely to limit either intracellular activity or secondary bacterial production.

To examine the potential response of bacteria to algal-derived photosynthate, light was also included as a variable during the simulation. Ralph et al. (2007) have recently shown that sea-ice algae exhibit least photosynthetic stress when maintained at $35 \%$ and $51 \%$ o salinity, whereas cultures at $16 \%$, $21 \%$ and $65 \%$ o suffered significant photosynthetic damage when concurrently exposed to high irradiance $(150 \mu \mathrm{mol}$ photons $\left.\mathrm{m}^{-2} \mathrm{~s}^{-1}\right)$. These stimuli, and the subsequent variation in microalgal photosynthetic exudates, would conceivably influence the concentration of photosynthate available for bacterial metabolism. While the combined effect of light and salinity was insignificant at $8 \%$, $21 \%$ o, $51 \%$ and $69 \%$, we do provide some evidence for a correlation between $\mathrm{CTC}+$ cells and microalgal photosynthetic activity for samples incubated at $32 \%$. At this salinity, the percentage of CTC+ cells was significantly higher at $77.5 \mu \mathrm{mol}$ photons $\mathrm{m}^{-2}$ $\mathrm{s}^{-1}$ compared to the dark treatment, but a decline in metabolic activity was evident at the highest incubation irradiance (Figure 3.4). This trend in bacterial activity might be expected given the response of microalgae cultured at $32 \%$ o to increasing light levels prior to the onset of photoinhibition at $262 \mu \mathrm{mol}$ photons $\mathrm{m}^{-2} \mathrm{~s}^{-1}$. The lack of covariation between light and salinity in the other treatments potentially reflects a severe inhibitory photosynthetic response to salinity (eg. Vargo et al. 1986, Arrigo \& Sullivan 1992, Ryan et al. 2004, Ralph et al. 2007), thereby limiting the production of microalgal exudates. 
A more convincing insight into the bacteria-algae relationship was provided by directly manipulating the availability of photosynthate. Unlike Kottmeier and Sullivan (Kottmeier \& Sullivan 1988) who added F/2 nutrients and vitamins to their incubations so as not to confound the response to salinity, a significant reduction in single-cell activity was observed by removing the majority of microalgal cells (filtered treatment) as well as inhibiting photosynthesis with DCMU (Figure 3.4). As would be predicted by the microbial loop hypothesis, irradiance had no effect on bacterial activity for samples spiked with DCMU, but by reducing DOM to a level well below saturation, a positive response to increasing irradiance was detected in the filtered treatment. Despite the implications for trophic dynamics and production within the sea-ice ecosystem, few studies have quantified the time required for bacteria to respond to algal metabolism. Grossmann and Gleitz (1993) examined the response of microbes to experimental seaice formation and determined that the period of time required before algal photosynthesis influenced bacterial production was in excess of two weeks. Our results, at least for melted ice cores, dramatically shorten this response time and show that bacterial intracellular activity can be influenced within $48 \mathrm{hr}$. This finding essentially describes changes in the spatial arrangement of the microbial community rather than an in situ temporal dynamic (Grossmann \& Gleitz 1993), but is still useful in quantifying the response time of a highly active bacterial community.

While the procedure of Ryan et al. (2004) is currently the best method for approximating in situ sea-ice conditions with minimal temperature changes during the melting process, the release of DOM from the ice matrix has been shown to enhance both primary and 
secondary production (Giesenhagen et al. 1999). Although DOM was not measured directly in this study, the observed increase in protein biosynthesis with $\left[{ }^{3} \mathrm{H}\right]$ leucine after $48 \mathrm{hr}$ provides evidence that secondary production can increase by two orders of magnitude at favourable saline concentrations. The ice thickness in the vicinity of Gondwana Station in 2007 was $1.8 \mathrm{~m}$ with a distinctly brown congelation layer indicative of the high microbial biomass. In contrast, the ice thickness had been $2.6 \mathrm{~m}$ the previous year. Light attenuation at this depth resulted in a significantly reduced biomass whereby it was possible to observe a weak covariation between light and salinity and manipulate the availability of DOM and bacterial metabolic activity.

Given the high attenuation of solar radiation by the sea-ice matrix, ultraviolet-induced effects are generally thought to influence the composition of microbial communities and patterns of succession rather than reduce primary or secondary productivity (see Marchant et al. 2001, Thomas \& Dieckmann 2002). Despite this emphasis on community-level change, damage to both RNA transcription and DNA replication has been observed in sea-ice microalgae, as have elevated levels of the protective mycosporine-like amino acid porphyra-334 (McMinn et al. 1999, Ryan et al. 2002). In contrast, marine bacteria are not thought to contain UV-screening pigments and exhibit responses that range from the reduction in survival and synthesis of DNA/protein, to positive growth associated with phytoplankton mortality and photodegradation of DOM molecules to a size that promotes bacterial consumption (Kaiser \& Herndl 1997, Davidson \& van der Heijden 2000). The potential for damage by different ranges of natural UV-A and UV-B wavelengths is not well known however (Davidson 1998, Hernandez et al. 2006) and to our knowledge no previous studies have examined the 
effect of UV-B radiation on Antarctic sea-ice bacteria. In a manipulative experiment examining Antarctic coastal seawater, Davidson \& van der Heijden (2000) exposed microbes to a range of ambient UV levels (equivalent depth range 1-20 m) for a period of 7 days. Although significant differences were found between high and low UV treatments, bacterial abundance increased under all irradiances following an initial lag period of 2 days. More recently, Nunez et al. (2006) have modelled the effect of UV radiation in Antarctic surface waters and determined a erythemally effective irradiance threshold of $28 \mathrm{~mW} \mathrm{~m}^{-2}$ (approximating noon-time irradiance at $3.6 \mathrm{~m}$ depth) above which increased phytoplankton mortality and protozoan biomass was observed, but no changes in bacterial biomass.

In contrast to observations from Antarctic coastal waters, we observed significant metabolic inhibition in ice-derived bacteria exposed to UV-B radiation. By combining the data from two experiments, we infer a reduction in single-cell activity during the melt process that is dose-dependent (Figure 3.5).Unlike Davidson \& van der Heijden (2000) or Nunez et al. (2006) who observed relatively minor changes in bacterial abundance, intracellular activity in bottom-ice bacteria was reduced to approximately $10 \%$ after a total dose of $12.5 \mathrm{~kJ} \mathrm{~m}^{-2}$ in $12 \mathrm{hr}$, while at $25 \mathrm{~kJ} \mathrm{~m}^{-2},<2 \%$ of the bacterial cells present were CTC+. Extrapolating from the erythemal action spectrum used by Nunez et al. (2006) and UV-B measurements collected in McMurdo Sound in 2007 (http://www.biospherical.com/nsf), $25 \mathrm{~kJ} \mathrm{~m}^{-2}$ is an ecologically relevant level of exposure for cells at the surface of the sea during the ice edge bloom and highlights the susceptibility of Antarctic sea-ice bacteria to rapid changes in UV-B exposure. Whether ice-derived bacteria show adaptive mechanisms to long-term UV-B exposure or 
potentially benefit from the stress response of other taxa during bloom events in the Southern Ocean is not known, however the initial exposure to increased UV-B causes significant metabolic stress.

These results show that metabolic activity in sea-ice bacteria is reduced during ice melt when hyposaline conditions are combined with increased UV-B exposure. In contrast, the bacteria present in the congelation layer at the time of sampling are likely to be psychrophilic and show a greater ability to acclimate to the hypersaline conditions that are typical of ice formation. With respect to microbial loop dynamics, single-cell analysis is a useful tool for establishing the real-time response of bacteria in manipulative experiments. Bacterial-algal linkages are clearly influenced by the transitional light and saline regimes during the freeze/thaw of the ice matrix, but I show that this dynamic is largely dependent on the relative abundance of bacteria and microalgae at the time of sampling. Further research is needed to quantify this relationship with respect to the temporal variability and spatial characteristics of the seaice matrix.

\subsection{Literature cited}

Ackley SF, Sullivan CW (1994) Physical controls on the development and characteristics of Antarctic sea ice biological communities - a review and synthesis. Deep-Sea Research 41: 1583-1604.

Arrigo KR, Sullivan CW (1992) The influence of salinity and temperature covariation on the photophysiological characteristics of Antarctic sea ice microalgae. Journal of Phycology 28: 746-756.

Azam F, Smith DC, Hollibaugh JT (1991) The role of the microbial loop in Antarctic pelagic ecosystems. Polar Research 10: 239-243.

Cota GF, Kottmeier ST, Robinson DH, Smith WO Jr, Sullivan CW (1990) Bacterioplankton in the marginal ice zone of the Weddell Sea: biomass, production and metabolic activities during austral autumn. Deep-Sea Research 37: 1145-1167. 
Davidson AT (1998) The impact of UVB radiation on marine plankton. Mutation Research 422: 119-129.

Davidson AT, van der Heijden (2000) Exposure of natural Antarctic marine microbial assemblages to ambient UV radiation: effects on bacterioplankton. Aquatic Microbial Ecology 21: 257-264.

Davidson AT, Thomson PG, Westwood K, van den Enden R (2004) Estimation of bacterioplankton activity in Tasmanian coastal waters and between Tasmania and Antarctica using stains. Aquatic Microbial Ecology 37: 33-45.

del Giorgio PA, Prairie YT, Bird DF (1997) Coupling between rates of bacterial production and the abundance of metabolically active bacteria in lakes, enumerated using CTC deduction and flow cytometry. Microbial Ecology 34: 144-154.

Delille DM, Fiala M, Rosiers C (1992) Marine bacterioplankton at the Weddell Sea ice edge, distribution of psychrophilic and psychrotrophic populations. Polar Biology 12: 205-210.

Delille DM, Fiala M, Kuparinen J, Kuosa H, Plessis C (2002) Seasonal changes in microbial biomass in the first-year ice of the Terre Adélie area (Antarctica). Aquatic Microbial Ecology 28: 257-265.

Falcioni TF, Papa S, Gasol JM (2008) Evaluating the flow-cytometric nucleic acid doublestaining protocol in realistic situations of planktonic bacterial death. Applied and Environmental Microbiology 74: 1767-1779.

Garrison DL (1991) Antarctic Sea Ice Biota. American Zoologist 31: 17-33.

Garrison DL, Gibson A, Coale SL, Gowing, MM, Okolodkov YB, Fritsen HF, Jeffries MO (2005) Sea-ice microbial communities in the Ross Sea: autumn and summer biota. Marine Ecology Progress Series 300: 39-52.

Gasol JM, Ariśtequi J (2007) Cytometric evidence reconciling the toxicity and usefulness of CTC as a marker of bacterial activity. Aquatic Microbial Ecology 46: 71-83.

Giesenhagen HC, Detmer AE, de Wall J, Weber A, Gradinger RR, Jochem, FJ (1999) How are Antarctic planktonic microbial food webs and algal blooms affected by melting of sea ice? Microcosm simulations. Aquatic Microbial Ecology 20: 183-201.

Grossi SM, Kottmeier ST, Sullivan CW (1984) Sea Ice Microbial Communities III. Seasonal abundance of microalgae associated bacteria in McMurdo Sound, Antarctica. Microbial Ecology 10: 231-242.

Grossmann S, Gleitz M (1993) Microbial responses to experimental sea-ice formation: implications for the establishment of Antarctic sea-ice communities. Journal of Experimental Marine Biology and Ecology 173: 273-289.

Hernandez EA, Ferreyra GA, Mac Cormack WP (2006) Response of two Antarctic marine bacteria to different natural UV radiation doses and wavelengths. Antarctic Science 18: 205212.

Junge K, Eicken H, Deming JW (2004) Bacterial activity at -2 to -20 degrees C in Arctic wintertime sea ice. Applied and Environmental Microbiology 70: 550-557.

Kaartokallio, H, Laamanen M, Sivonen K (2005) Responses of Baltic sea ice and open-water natural bacterial communities to salinity change. Applied and Environmental Microbiology 71: 4364-4371.

Kaiser E, Herndl GH (1997) Rapid recovery of marine bacterioplankton activity after inhibition by UV radiation in coastal waters. Applied and Environmental Microbiology 63: 4026-4031.

Kirchman D (2001) Measuring bacterial biomass production and growth rates from leucine incorporation in natural aquatic environments. In: Paul JH (ed) Methods in microbiology, vol. 30, marine microbiology. Academic Press, p 227-238.

Kottmeier ST, Sullivan CW (1988) Sea Ice Microbial Communities IX. Effects of temperature and salinity on metabolism and growth of autotrophs and heterotrophs. Polar Biology 8: 293-304. 
Kottmeier ST, Sullivan CW (1990) Bacterial biomass and production in pack ice of Antarctic marginal ice edge zones. Deep-Sea Research 37: 1311-1330.

Kottmeier ST, McGrath Grossi S, Sullivan CW (1987) Sea ice microbial communities. VIII. Bacterial production in annual sea ice of McMurdo Sound, Antarctica. Marine Ecology Progress Series 35: 175-186.

Legendre L, Ackley SF, Dieckmann, GS, Gulliksen B, Horner R, Hoshiai T, Melnikov IA, Reeburgh WS, Spindler M, Sullivan CW (1992) Ecology of sea ice biota. 2. Global Significance. Polar Biology 12: 429-444.

Longnecker K, Sherr BF, Sherr EB (2005) Activity and phylogenetic diversity of bacterial cells with high and low nucleic acid content and electron transport system activity in an upwelling ecosystem. Applied and Environmental Microbiology 71: 7737-7749.

McMinn A, Ashworth C, Ryan K (1999) Growth and productivity of Antarctic sea ice algae under PAR and UV irradiances. Botanica Marina 42: 401-407.

McMinn A, Ryan KG, Gademann R (2003) Diurnal changes in photosynthesis of Antarctic fast ice algal communities determined by pulse amplitude modulation (PAM) fluorometry. Marine Biology 143: 405-13.

Marchant HJ, Davidson AT, Wright SW (2001) Antarctic marine microorganisms and climate change: impacts and feedbacks. Ocean and Polar Research 23: 401-410.

Martin A, Hall JA, O'Toole R, Davy SK, Ryan KG (2008) High single-cell metabolic activity in Antarctic sea ice bacteria. Aquatic Microbial Ecology 52: 25-31.

Morán XAG, Calvo-Diaz A (2009) Single-cell vs. bulk activity properties of coastal bacterioplankton over an annual cycle in a temperate ecosystem. FEMS Microbiology Ecology 67: 43-56.

Nichols DS, Greenhill AR, Shadbolt CT, Ross T, McMeekin TA (1999) Physiochemical parameters for growth of the sea ice bacteria Glaciecola punicea ACAM $611^{\mathrm{T}}$ and Geldicacter sp. Strain IC158. Applied and Environmental Microbiology 65: 3757-3760.

Nichols DS, Olley J, Garda H, Brenner RR, McMeekin TA (2000) Effect of temperature and salinity stress on growth and lipid composition of Shewanella gelidimarina. Applied and Environmental Microbiology 66: 2422-2429.

Ralph PJ, McMinn A, Ryan KG (2005) Short-term effect of temperature on the photokinetics of microalgae from the surface layers of Antarctic pack ice. Journal of Phycology 41: 763-769.

Ralph PJ, Ryan KG, Martin A, Fenton G (2007) Melting out of sea ice causes greater photosynthetic stress in algae than freezing in. Journal of Phycology 43: 948-956.

Ryan KG, Ralph P, McMinn A (2004). Acclimation of Antarctic bottom-ice algal communities to lowered salinities during melting. Polar Biology 27: 679-686.

Ryan KG, McMinn A, Mitchell KA, Trennery L (2002) Mycosporine like amino acids in Antarctic sea ice algae, and their response to UVB radiation. Zeitschrifft fur Naturforshhung 57 C: 461-477.

Schumann R, Schiewer U, Karsten U, Rieling T (2003) Viability of bacteria from different aquatic habitats. II. Cellular fluorescent markers for membrane integrity and metabolic activity. Aquatic Microbial Ecology 32: 137-150.

Sherr BF, Sherr E, del Giorgio PA (2001) Enumeration of total and highly active bacteria. In: Paul J (ed) Methods in Microbiology, Vol 30. Marine Microbiology. Academic Press, London, p 129-159.

Stewart FJ, Fritsen CH (2004) Bacteria-algae relationships in Antarctic sea ice. Antarctic Science 16: 143-156.

Sullivan CW, Palmisano AC (1984) Sea ice microbial communities: Distribution, abundance, and diversity of ice bacteria in McMurdo Sound, Antarctica, in 1980. Applied and Environmental Microbiology 47: 788-795.

Thomas DN, Dieckmann GS (2002) Antarctic sea ice - a habitat for extremophiles. Science 295: 641-644. 
Vaqué D, Calderon-Paz JI, Guixa-Boixereu N, Pedros-Alio C (2002) Spatial distribution of microbial biomass and activity (bacterivory and bacterial production) in the northern Weddell Sea during the austral summer (January 1994). Aquatic Microbial Ecology 29: 107121.

Vargo GA, Fanning K, Heil C, Bell L (1986) Growth rates and the salinity response of an Antarctic ice microfloral community. Polar Biology 5: 241-247. 


\section{CHAPTER 4}

Can microcosm simulations be used to infer microbial loop dynamics in Antarctic sea-ice?

\subsection{Abstract}

Although the assimilation of dissolved organic matter (DOM) by heterotrophic bacteria is a core process in the microbial loop hypothesis, this dynamic remains equivocal in the Antarctic sea-ice ecosystem due to the spatial and temporal variability of the in situ microbial community. Microalgae actively contribute to the pool of DOM available for bacterial metabolism, but this link has historically relied on bulk correlations of chlorophyll $a$ (a surrogate for phytoplankton biomass) and bacterial abundance. In this study, I determined whether microcosm simulations provide an enhanced degree of experimental resolution by incubating microbes from both the congelation layer and high-brine region of Antarctic fast-ice for $9 \mathrm{~d}$. Algalderived photosynthate was manipulated by varying the incubation irradiance (light: dark, 14:10 h, light $150 \mu \mathrm{mol}$ photons $\left.\mathrm{m}^{-2} \mathrm{~s}^{-1}\right)$, inhibiting photosynthesis with 3-(3,4dichlorophenyl)-1,1-dimethylurea (DCMU) or incubating microbes in the dark. The cell-specific assay 5-cyano-2,3-ditolyl tetrazolium chloride (CTC) was used to quantify bacterial metabolic activity and variation in bacterial community composition was examined using denaturing gradient gel electrophoresis (DGGE). CTC+ bacteria were relatively low in the brine microcosm (10-20\%) and photosynthate limitation in the DCMU treatment restricted bacterial growth and significantly influenced community structure. Metabolic activity was higher (35- 
$69 \%$ ) in the bottom-ice microcosm but DCMU was less influential with respect to changes in bacterial abundance or DGGE band patterns due to the higher concentration of DOM. Limited variation was observed between the variable light and dark treatments, but grazing by microzooplankton (inferred by changes in chlorophyll $a$ ) was evident in both experiments, and accounted for a significant loss of bacterial cells in the bottom-ice microcosm. While a mechanistic understanding of productivity and trophodynamics in the Antarctic sea ice ecosystem will ultimately require techniques that probe the spatial confines of the ice matrix, these results illustrate the potential for in situ microbial loop dynamics beyond the use of bulk comparisons.

\subsection{Introduction}

Productivity in the Southern Ocean is characterised by large-scale spatial and temporal variability. This is primarily due to the annual expansion and contraction of sea- ice around the Antarctic continent that influences not only pelagic systems under the ice, but enhances the ecological variability and productivity of the within-ice biota (Legendre et al.1992, Ackley \& Sullivan 1994). Heterotrophic bacteria are an essential component of this community, but an understanding of the diversity and functional capabilities of these microbes remains fragmentary, particularly with respect to community-level processes such as carbon cycling (Ducklow et al. 1999, Stewart \& Fritsen 2004). However, the high degree of in situ metabolism and tight seasonal coupling between the relative abundance of bacteria and microalgae has led several authors to propose an active microbial loop, similar to that of temperate oceanic systems (Sullivan \& Palmisano 1984, Azam et al. 1991). This relationship is thought to develop when bacteria assimilate dissolved organic matter (DOM) that is 
generated through processes such as the direct release of algal photosynthate, the production of algal-derived exopolymeric substances, or the rupture and degradation of algal cells during grazing (Grossi et al. 1984, Thomas \& Dieckmann 2002, Azam \& Malfatti 2007). In return, bacteria are thought to facilitate algal-based primary production by providing vitamins and/or recycled inorganic nutrients required for continued growth (Kottmeier et al. 1987, Kottmeier \& Sullivan, 1990, Archer et al. 1996).

Although a central tenet in the microbial loop hypothesis, the assimilation of algalderived DOM by bacteria remains equivocal with respect to community variability in the sea-ice ecosystem (Ducklow et al. 1999, Stewart \& Fritsen 2004). For example, several authors have found a positive relationship between bacteria and microalgae in sea- ice during the austral spring or summer by comparing the concentration of chlorophyll $a(\mathrm{Chl} a)$ (a surrogate for phytoplankton biomass) with bulk bacterial abundance or production estimates (Grossi et al.1984, Kottmeier et al. 1987, Kottmeier \& Sullivan 1990, Delille et al.1994, Stewart \& Fritsen 2004). In contrast, Kottmeier \& Sullivan (1987) and Stewart \& Fristen (2004) observed primary and secondary bacterial production to be uncoupled in late winter sea-ice west of the Antarctic Peninsula. While the potential for co-variation between autotrophic and heterotrophic biomass is thought to reflect factors such as the relative age of the ice and synergistic effects of DOM and in situ ice temperatures (Helmke \& Weyland 1995, Pomeroy \& Wiebe 2001, Stewart \& Fritsen 2004), the variability associated with this dynamic is not well understood. 
An alternative methodology with which to quantify trophic interactions is micro- or mesocosm simulation using seawater cultures. This technique provides an enhanced degree of experimental resolution (albeit at the expense of being a natural ecosystem) whereby factors of interest can be controlled during manipulative experiments. With respect to the assimilation of DOM, this approach has been used to mimic bloom events in Antarctic waters to ascertain possible 'seeding' by ice-derived organisms (Giesenhagen et al. 1999), and to calibrate growth rates of bacteria in the vicinity of the Ross Sea polynya (Ducklow et al. 1999). Interestingly, both these studies reported a positive response by the respective bacterial communities to dissolved organic substances and these findings are likely to reflect in situ microbial dynamics.

Quantifying productivity and trophodynamics in the Antarctic coastal ecosystem clearly requires an understanding of how factors such as ice type, date of ice formation, and seasonal development influence both the link between bacterial and algal metabolism and the subsequent cycling of energy through the sea-ice microbial community (Stewart \& Fritsen 2004). This is particularly challenging however, given that dissolved salts are excluded from the freshwater matrix during freezing and microbes become concentrated in microscopic pockets of liquid brine within the ice (Garrison, 1991). The majority of research efforts have thus relied on bulk analyses of melted ice samples or extracted brine (Jung et al. 2001), but these investigations do not resolve the spatial arrangement of microbes within the ice and offer only a temporal snapshot of the microbial community. Martin et al. (accepted) have recently examined the short-term response of sea-ice bacteria to salinity, visible and UV-B radiation and simulating the annual freeze/thaw cycle of the ice matrix provided a useful context for working with microbes derived from melted ice cores. With 
respect to the influence of algal-derived DOM however, this study observed only a weak influence on bacterial metabolism following a $48 \mathrm{~h}$ period of incubation. A clearer insight into microbial dynamics may potentially be gained by performing longer-tem incubations, but the extent to which simulations are useful in understanding sea-ice microbial processes is a major caveat to this approach.

In this study, I conduct microcosm simulations using sea-ice microbes from both the congelation layer and high-brine region of Antarctic fast-ice. Over a 9-day period, I manipulate the supply of algal-derived photosynthate available for bacterial metabolism by inhibiting photosynthesis or varying the light exposure during incubation. The cell-specific assay 5-cyano-2,3-ditolyl tetrazolium chloride (CTC) is used to quantify bacterial metabolic activity and potential shifts in bacterial community composition are examined by means of denaturing gradient gel electrophoresis (DGGE).

\subsection{Materials and methods}

\subsubsection{Bottom community experiment}

Sea-ice bacteria and microalgae were collected in December 2005 from fast- ice approximately $2 \mathrm{~m}$ thick at O'Brien Bay (in the vicinity of Casey Station), Antarctica $\left(66^{\circ} 18^{\prime} \mathrm{S}, 110^{\circ} 22^{\prime} \mathrm{E}\right)$. Three holes $(<1.2 \mathrm{~m})$ were drilled in close proximity with a powered ice auger (Jiffy, USA) and cores (200-300 mm long, $130 \mathrm{~mm}$ diameter) were extracted from the bottom of each profile using a Kovaks (Kovaks, USA) ice corer. To prevent light shock, all operations were performed under a black sheet and each core was transported in a black plastic tube. Sea-ice microbes were obtained by cutting off the bottom $30 \mathrm{~mm}$ of each core and melting each section in a sterile 
container with $500 \mathrm{ml}$ of $0.22 \mu \mathrm{m}$-filtered sea water $\left(35 \%,-1.8^{\circ} \mathrm{C}\right)$, under low-light $\left(<1 \mu \mathrm{mol}\right.$ photons $\left.\mathrm{m}^{-2} \mathrm{~s}^{-1}\right)$, over a period of $12 \mathrm{~h}$ (Ryan et al. 2004). The cells from each core were combined in a single container using plastic pipettes with a final volume of approximately $500 \mathrm{ml}$ and saline concentration of $\sim 36 \%$. Triplicate $60 \mathrm{ml}$ samples were then prepared in $250 \mathrm{ml}$ breathable culture flasks. For the DCMU treatment, 3-(3,4-dichlorophenyl)-1,1-dimethylurea (Sigma, USA) was added at a final concentration of $10^{-6} \mathrm{M}$ on Days 1 and 5. Incubations were performed in a water bath maintained at $-1.8^{\circ} \mathrm{C}$. An ethanol: water (1:4) mix was used in the bathing solution to provide sub-zero temperatures and a heater stirrer was used to maintain the incubator to within $\pm 0.2^{\circ} \mathrm{C}$. During the $9 \mathrm{~d}$ incubation period, samples were assigned to either a light:dark regime of $14: 10 \mathrm{~h}$, light $150 \mu \mathrm{mol}$ photons $\mathrm{m}^{-2} \mathrm{~s}^{-1}$, light:dark regime with the addition of DCMU, or kept in the dark. Each culture flask was sub-sampled on Days 1,5 and 9 to determine a) bacterial cell abundance and b) bacterial community composition. For cell counts, $2 \mathrm{ml}$ sub-samples were fixed using a combination of gluteraldehyde ( $0.05 \%$ final concentration) and paraformaldehyde ( $4 \%$ final concentration) and frozen at $-20^{\circ} \mathrm{C}$. For community composition analysis, $2 \mathrm{ml}$ sub-samples were filtered onto a $0.22 \mu \mathrm{m}$ filter (Millipore, USA) and frozen at $-80^{\circ} \mathrm{C}$. At the conclusion of the experiment, additional measurements were made from each culture flask to determine Chlorophyll $a(\mathrm{Chl} a)$ concentration and single-cell bacterial metabolic activity. For Chl $a$ measurements, $35 \mathrm{ml}$ from each culture flask was filtered onto a $47 \mathrm{~mm} \mathrm{GF/F}$ filter and extracted in $10 \mathrm{ml}$ of methanol over $12 \mathrm{~h}$ in the dark at $4^{\circ} \mathrm{C}$. The extracted Chl $a$ was subsequently measured on a digital fluorometer (10AU Turner Designs, USA.) using the acidification protocol of Evans et al. (1987). Single-cell metabolic activity was determined for each culture flask using 5-cyano-2,3-ditolyl tetrazolium 
chloride (CTC). Triplicate $900 \mu \mathrm{l}$ samples were prepared in $1 \mathrm{ml}$ Eppendorf tubes and CTC was added to each sample at a final concentration of $5 \mathrm{mM}$. Samples were then incubated in the dark at $-1.8 \pm 0.2^{\circ} \mathrm{C}$ in the water bath for $3 \mathrm{~h}$. Cell activity was terminated with the addition of $50 \mu \mathrm{l}$ of $0.22 \mu \mathrm{m}$-filtered formalin (5\% final concentration) and samples were immediately frozen in liquid nitrogen (Sherr et al. 1999). Prior to incubation, time zero measurements of bacterial abundance, metabolic activity and $\mathrm{Chl} a$ were obtained from the unfiltered stock solution using the methods detailed above.

\subsubsection{Brine community experiment}

Microbes were collected from annual fast ice near Gondwana Station (Terra Nova Bay), Antarctica $\left(74^{\circ} 38^{\prime} \mathrm{S}, 164^{\circ} 13^{\prime} \mathrm{E}\right)$ in November 2007 . Approximately 1.5 litres of brine ( 70\%o) was collected from a hole drilled to a depth of $300 \mathrm{~mm}$ using a Kovaks (Kovaks, USA) ice corer. To minimise light shock, the brine was collected under a black sheet and transported with minimal disturbance in an opaque container. Triplicate $100 \mathrm{ml}$ samples were prepared in $250 \mathrm{ml}$ breathable culture flasks as detailed earlier. Incubation temperature and irradiance regimes were identical to those of the bottom-ice community experiment. Each culture flask was sub-sampled on Days 1, 5 and 9 to determine a) bacterial cell abundance and b) bacterial community composition. Given the lower microbial biomass present in brine, $10 \mathrm{ml}$ rather than $2 \mathrm{ml}$ was sub-sampled from each flask for community composition analysis. Pre and post-incubation estimates of bacterial abundance, metabolic activity and Chl $a$ were also determined. 


\subsubsection{Enumeration of bacteria}

Bacterial samples were analysed on a Becton-Dickinson LSR II flow cytometer equipped with a $20 \mathrm{~mW}, 355 \mathrm{~nm}$, Lightwave solid state laser and standard filter setup. Initial instrument calibration was performed using FACSDiva software in conjunction with Becton Dickinson SPHERO ${ }^{\mathrm{TM}}$ Rainbow calibration particles. $500 \mu \mathrm{l}$ of each sample was stained in the dark for 10 minutes with DAPI (final concentration $5 \mu \mathrm{g} \mathrm{ml}^{-1}$ ) and TruCount beads (Becton Dickinson, USA) were subsequently added in order to accurately determine the volume of sample processed. To avoid coincidence, samples were run at a medium flow rate with less than 1300 events per second. Bacterial cell populations were identified from bivariate plots of blue fluorescence (FL4) vs. SSC (Side Scatter).

Given the high saline concentration of the brine samples, $500 \mu \mathrm{l}$ of each sample was initially diluted with $500 \mu \mathrm{l}$ of $0.22 \mu \mathrm{m}$-filtered dionised water and then stained for $10 \mathrm{~min}$ in the dark with DAPI (final concentration $5 \mu \mathrm{g} \mathrm{ml}^{-1}$ ). Samples were analysed using the LSR II. Bacterial cell populations were identified from bivariate plots of blue fluorescence (FL4) Vs. SSC (Side Scatter).

\subsubsection{Enumeration of CTC+ bacteria}

Enumeration of CTC+ cells was performed using a BD Biosciences FACScan flow cytometer equipped with a $15 \mathrm{~mW}, 488 \mathrm{~nm}$, air-cooled argon ion laser and standard filter set-up. Initial instrument calibration was performed using FACScomp software in conjunction with CaliBRITE reference beads (Becton Dickinson, USA). TruCount beads (Becton Dickinson, USA) were added to each sample in order to accurately calculate the volume of sample analysed. Bacterial data were typically collected for 2 
min (acquisition of 200 TruCount beads) and CTC + positive cells were identified from bivariate plots of red (FL3) vs. orange (FL2) fluorescence. Total bacterial counts were determined by re-running each sample following a 10 min incubation with SYBR Green II (Molecular Probes, USA) and examining bivariate plots of green (FL1) fluorescence Vs. SSC (Side Scatter).

\subsubsection{Nucleic acid extraction and PCR amplification of bacterial 16S rRNA} genes

Bacterial genomic DNA was obtained from each filter (bottom-ice and brine community experiments) using a phenol/chloroform/isoamylalcohol extraction and ethanol precipitation as described by Schäfer \& Muyzer (2001). A 194 bp 16S rRNA fragment targeting the V3 region was amplified using primers 357F (CCT ACG GGA GGC AGC AG) and 518R (ATT ACC GCG GCT GCT GG). An additional 40 nucleotide GC-rich sequence (GC-clamp) was added to the 5' end of primer 357F. PCR amplification was performed in a volume of $25 \mu \mathrm{l}$ using illustra PuReTaq Ready-To-Go ${ }^{\mathrm{TM}}$ PCR beads (GE Healthcare, UK) and between 1-3 $\mu$ l of DNA template. PCR cycling was performed with a Eppendorf Thermal Cycler and the temperature-cycling conditions were as follows: initial denaturation at $94^{\circ} \mathrm{C}$ for 5 minutes; 10 touchdown cycles of denaturation (at $94^{\circ} \mathrm{C}$ for 1 minute), annealing (for 1 minute, $65-55^{\circ} \mathrm{C}$ decreasing $1{ }^{\circ} \mathrm{C}$ each minute) and extension (at $72^{\circ} \mathrm{C}$ for 3 minutes); 20 standard cycles (denaturing at $94^{\circ} \mathrm{C}$ for 1 minute, annealing at $55^{\circ} \mathrm{C}$ for 1 minute and extension at $72^{\circ} \mathrm{C}$ for 3 minutes) and a final extension at $72^{\circ} \mathrm{C}$ for 5 minutes. PCR products were quantified by agarose gel electrophoresis using a molecular size standard (Hyperladder I, Bioline, UK). 


\subsubsection{DGGE analysis of 16S rRNA gene fragments}

Denaturing gradient gel electrophoresis (DGGE) was performed with a D-Code ${ }^{\mathrm{TM}}$ Universal Mutation Detection System (Bio-Rad, USA). For each sample, approximately $500 \mathrm{ng}$ of PCR product was loaded on a $8 \%(\mathrm{wt} / \mathrm{vol})$ polyacrylamide gel (acrylamide and N,N'-methylene bisacrylamide at a ratio of 37:1) with a denaturing gradient that ranged from 40 to $70 \%$ (where $100 \%$ is defined as $7 \mathrm{M}$ urea and $40 \%$ deionized formamide). Gels were run for $18 \mathrm{~h}$ at a constant voltage of 100 $\mathrm{V}$ at $60^{\circ} \mathrm{C}$ in $1 \mathrm{x}$ TAE buffer (40 mM Tris [pH 7.4], $20 \mathrm{mM}$ sodium acetate, $1 \mathrm{mM}$ EDTA). Gels were subsequently stained with a 1:10,000 dilution of SYBR Gold (Molecular Probes, USA) for 30 minutes, rinsed, and visualised under UV excitation with a fluorescence image analyser. Cluster analysis of DGGE band patterns was performed using BioNumerics (Applied Maths, Belgium). Patterns were compared using the Dice similarity coefficient and UPGMA (unpaired pair-wise grouping with mathematical averages) to generate dendrograms.

\subsubsection{Sequencing and comparative sequence analysis}

DGGE bands of interest were excised using a sterile razor blade and the DNA eluted in $500 \mu \mathrm{l}$ of PCR-grade water for $48 \mathrm{~h}$. A total of $2 \mu \mathrm{l}$ of the eluate was used for reamplification with the original primer set. A portion of the PCR product from the second amplification was reanalysed by DGGE to verify the correct band position. PCR products were then purified using Exo-SAP IT (USB Corporation, USA) and quantified in an agarose gel using a molecular size standard (Hyperladder I, Bioline, UK). PCR products were sequenced with the BigDye terminator ready reaction cycle sequencing kit using both forward (357F) and reverse (518R) primers. Sequencing reactions were analysed on an ABI3730 Genetic Analyser and were compared with 
available databases using the Basic Local Alignment Search Tool (BLAST). The partial and complete 16S rRNA gene sequences were aligned using Geneious (Version 4.5.1) which incorporates CLUSTALW and a phylogenetic tree was constructed in PAUP* using the Jukes-Cantor method and neighbour-joining algorithm. Bootstrap values were obtained from the analysis of 10000 re-samplings of the data set. The partial environmental 16S rRNA gene sequences recovered in this study will be deposited in the GenBank nucleotide sequence database.

\subsubsection{Statistical analyses}

Data were analysed using SPSS (Version 17.0). For both the brine and bottom-ice experiments a mixed between-within subjects analysis of variance (repeated measures) was used to compare the effects of incubation treatment and time on the abundance of bacterial cells.

\subsection{Results}

\subsubsection{Brine community}

A change in the total abundance of brine bacteria was observed for both the light/dark and dark treatments with an approximate increase from 2.5 to $8 \times 10^{4}$ cells $\mathrm{ml}^{-1}$ by Day 9 (Figure 4.1). In contrast, there was relatively little variation in the abundance of bacteria in samples spiked with DCMU between Days 1-9 ( 4 x 104 cells $\mathrm{ml}^{-1}$ ). Mixed between-within subjects ANOVA revealed a significant interaction between treatment and time (Wilks' $\lambda=0.162, F_{4,10}=3.7, P=0.042$ ). CTC+ cells varied between $10-20 \%$ on Day 9 , but no difference in single-cell activity between treatments was detected $\left(F_{2,6}=2.822, P=0.137\right)$. The concentration of Chl $a$ at the end of the experiment differed significantly between treatments $\left(F_{2,6}=\right.$ 
29.535, $P=0.001$ ) with significantly less Chl $a$ in the DCMU treatment compared to either the light/dark or dark treatments (Tukey post-hoc test)(Table 4.1).

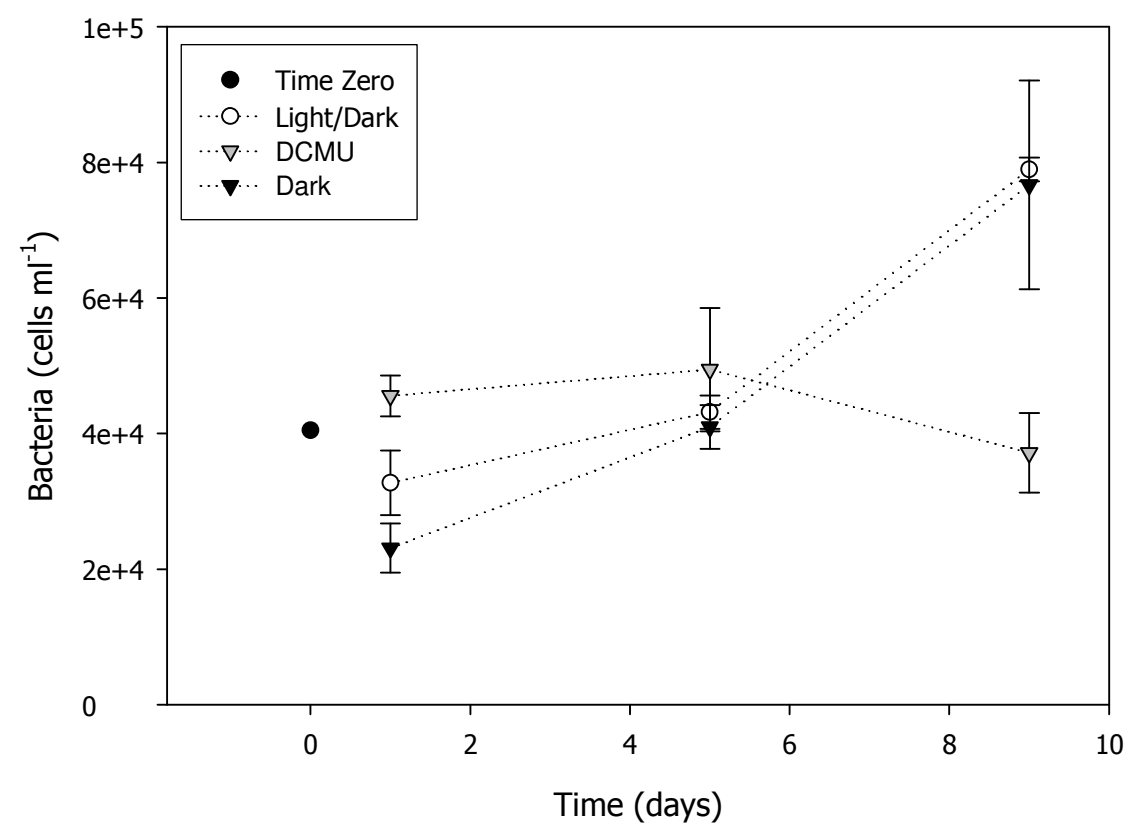

Figure 4.1: Total abundance of brine bacteria collected from annual fast-ice and incubated at $-1.8^{\circ} \mathrm{C}$ for $9 \mathrm{~d}$. Time Zero $=$ initial post-melt cell concentration; Light/Dark $=14: 10 \mathrm{hr}, 150 \mu \mathrm{mol}$ photons $\mathrm{m}^{-2} \mathrm{~s}^{-1}$ :Dark; DCMU = light/dark regime and addition of 3-(3,4-dichlorophenyl)-1,1-dimethylurea; Dark = zero light exposure. Data are means \pm 1 SE.

Bacterial fingerprints of the most dominant populations were obtained after separation of 16S rRNA gene fragments by DGGE. Cluster analysis of the banding patterns generated for each treatment and time point was performed using UPGMA incorporating a Dice correlation coefficient. Analysis of the initial bacterial community (Time Zero), and three subsequent treatment regimes on Days 1, 5 and 9 revealed between 12 and 17 bands in each fingerprint and band patterns indicated a distinct division between treatments and also a change in bacterial community structure with respect to time (Figure 4.2). Fingerprints generated from the DCMUspiked cultures were $<60 \%$ similar to the other treatments (with the exception of dark Day 1) while temporal variation in band patterns was relatively constrained. A higher 
degree of similarity was found between cultures exposed to a light/dark regime and those confined to the dark, particularly on Days 5 and 9.

Variation between the time zero fingerprint and the banding patterns observed $24 \mathrm{~h}$ later in the dark and DCMU treatments was significant (40\% similarity), but less variation was evident in comparison with Day 1 of the light treatment $(>50 \%$ similarity). Among the phylotypes that were abundant during the experiment, three were excised and successfully sequenced. Two were affiliated with the genus Psychromonas from the $\gamma$ subdivision of the Proteobacteria, while the third sequence was most closely related to an uncultured bacterial clone (Table 4.2, Figure 4.5).

Table 4.1: Post-incubation estimates of single-cell metabolic activity and Chl $a$ concentration for bottom-ice and brine microbial communities incubated for 9-d at $-1.8^{\circ} \mathrm{C}$. Time Zero $=$ initial post-melt cell concentration; Light/Dark $=14: 10 \mathrm{~h}, 150$ $\mu \mathrm{mol}$ photons $\mathrm{m}^{-2} \mathrm{~s}^{-1}$ :dark; DCMU = light/dark regime combined with 3-(3,4dichlorophenyl)-1,1-dimethylurea; Dark = zero light exposure, $\mathrm{CTC}+=$ percentage of bacteria undergoing active metabolism Data are means $\pm 1 \mathrm{SE}$.

\begin{tabular}{cccccc}
\hline & Time Zero & n & Light/Dark & DCMU & Dark \\
\hline Bottom community & & & & & \\
CTC+ & 60 & 3 & $54 \pm 8.2$ & $42 \pm 5.5$ & $53 \pm 5.6$ \\
Chl $a\left(\mu \mathrm{g}^{-1}\right)$ & 1000 & 3 & $271.67 \pm 13.60$ & $268.33 \pm 62.43$ & $356.33 \pm 32.64$ \\
& & & & & \\
Brine community & & & & & \\
CTC+ & 21 & 3 & $14 \pm 0.6$ & $12 \pm 1.2$ & $16 \pm 1.7$ \\
Chl $a\left(\mu \mathrm{g}^{-1}\right)$ & 290.5 & 3 & $139.00 \pm 13.80$ & $57.23 \pm 4.97$ & $147.33 \pm 6.06$ \\
\hline
\end{tabular}




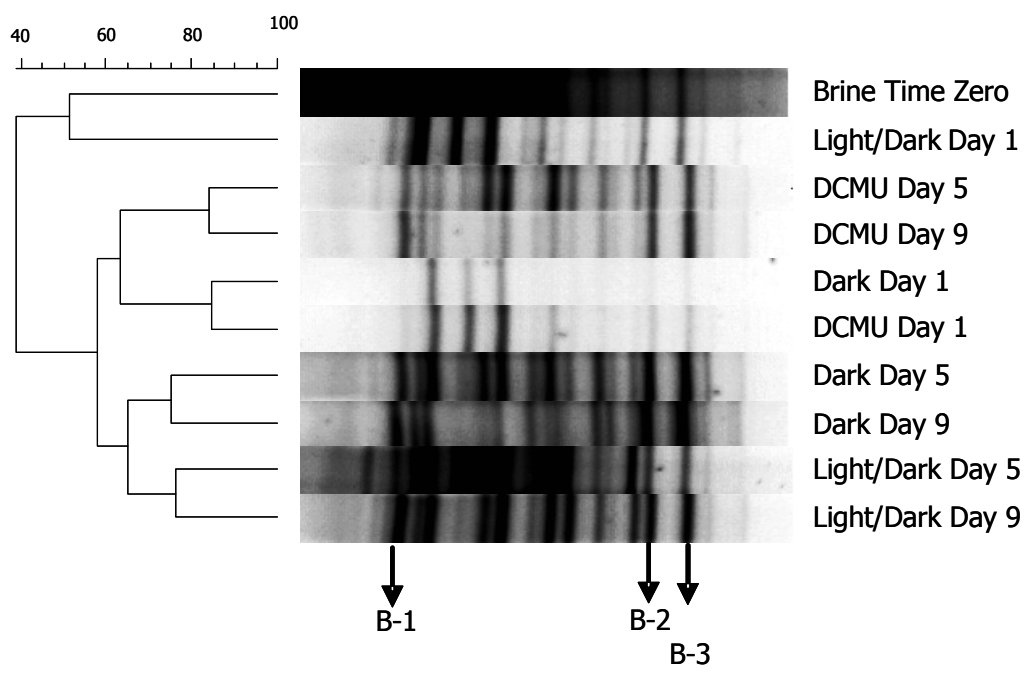

Figure 4.2: Comparison of DGGE fingerprints of 16S rRNA gene fragments amplified from DNA templates of brine bacteria incubated for $9 \mathrm{~d}$. Dendrogram is generated by cluster analysis (Dice correlation coefficient - UPGMA) of DGGE fingerprints obtained with primers $357 \mathrm{~F}$ and $518 \mathrm{R}$. B-1, B-2, B-3 = bands excised for sequencing.

\subsubsection{Bottom-ice community}

The total abundance of ice-derived bacteria increased from approximately $2 \times 10^{5}$ cells $\mathrm{ml}^{-1}$ to $4 \times 10^{5}$ cells $\mathrm{ml}^{-1}$ between Days $1-5$ in the light/dark and dark-only incubation regimes. In the DCMU treatment the bacterial abundance only increased to $3 \times 10^{5}$ cells $\mathrm{ml}^{-1}$ by Day 5 . The total abundance of bacteria declined dramatically in all treatments between Days 5-9 (Figure 4.3). Mixed between-within subjects ANOVA showed no significant interaction between treatment and time variables (Wilks' $\lambda=0.525, F_{4,10}=0.917, P=0.491$ ), but there was a substantial main effect of time (Wilks' $\lambda=0.203, F_{2,5}=9.81, P=0.019$ ) and significant difference between treatments $\left(F_{2,6}=5.912, P=0.038\right)$. A post-hoc Tukey test indicated that the abundance of bacteria incubated under the light/dark regime was significantly higher than the DCMU treatment. The percentage of metabolically active bacteria assayed on Day 9 varied between 35-69\% but there was no significant difference between treatments $\left(F_{2,6}=1.11, P=0.389\right)$. The concentration of chlorophyll $a$ was 
significantly lower in all samples on Day 9 in comparison to the initial post-melt measurement, but there was no difference among treatments $\left(F_{2,6}=1.45, P=\right.$ 0.306)(Table 4.1).

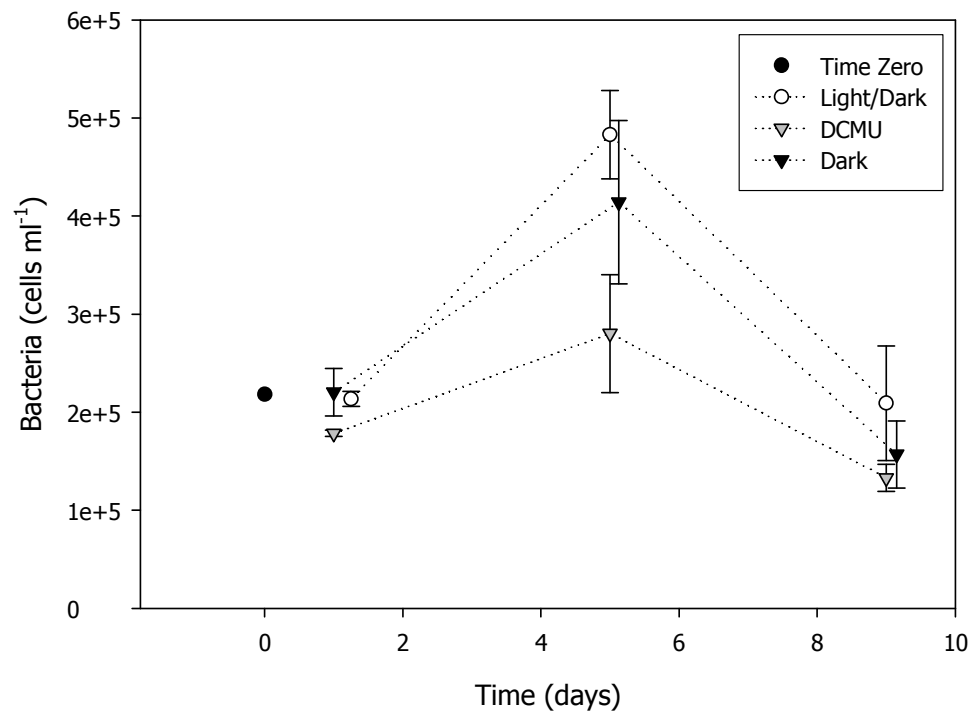

Figure 4.3: Total abundance of bottom-ice bacteria collected from annual fast ice and incubated at $-1.8^{\circ} \mathrm{C}$ for $9 \mathrm{~d}$. Time Zero $=$ initial post-melt cell concentration; Light/Dark $=14: 10 \mathrm{hr}, 150 \mu \mathrm{mol}$ photons $\mathrm{m}^{-2} \mathrm{~s}^{-1}$ :dark; DCMU = light/dark regime combined with 3-(3,4-dichlorophenyl)-1,1-dimethylurea; Dark = zero light exposure. Data are means $\pm 1 \mathrm{SE}$.

Bacterial fingerprints of the most dominant populations were obtained after separation of 16S rRNA gene fragments by DGGE. Cluster analysis of the banding patterns generated for each treatment and time point was performed using UPGMA incorporating a Dice correlation coefficient. Between 11 and 13 distinct bands were observed in each fingerprint using primers $357 \mathrm{~F}$ and 518R (Figure 4.4). Significant variation in banding patterns with respect to treatment was not observed. The degree of similarity with the time zero fingerprint was $70 \%$ for Day 1 of the light/dark treatment and $\sim 60 \%$ for all other fingerprints. For samples spiked with DCMU, fingerprints generated on Days 1, 5 and 9 displayed $>70 \%$ similarity. Three 
individual bands that were common to each fingerprint were amplified and sequenced from the DGGE gel. Given that the lengths of the resolved partial 16S rRNA sequences were only in the region of 160 nucleotides, each band showed moderate similarity with GenBank sequences of bacteria originating from polar regions (Table 4.2, Figure 4.5).

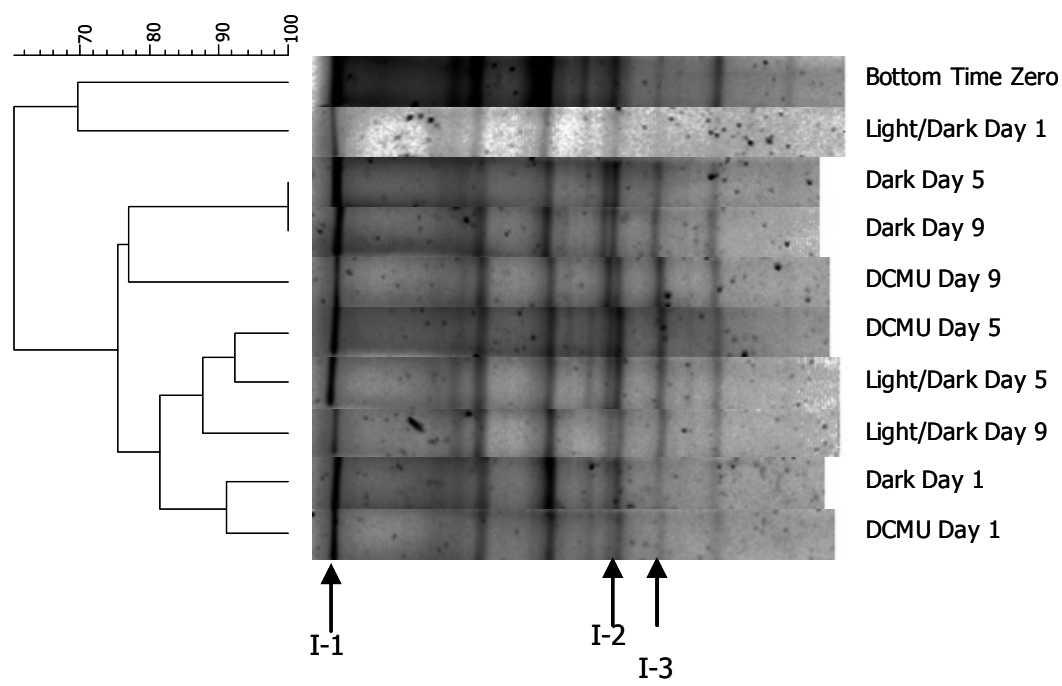

Figure 4.4: Comparison of DGGE fingerprints of 16S rRNA gene fragments amplified from DNA templates of bottom-ice bacteria incubated for $9 \mathrm{~d}$. Dendrogram is generated by cluster analysis (Dice correlation coefficient UPGMA) of DGGE fingerprints obtained with primers 357F and 518R. I-1, I-2, I-3 $=$ bands excised for sequencing. 


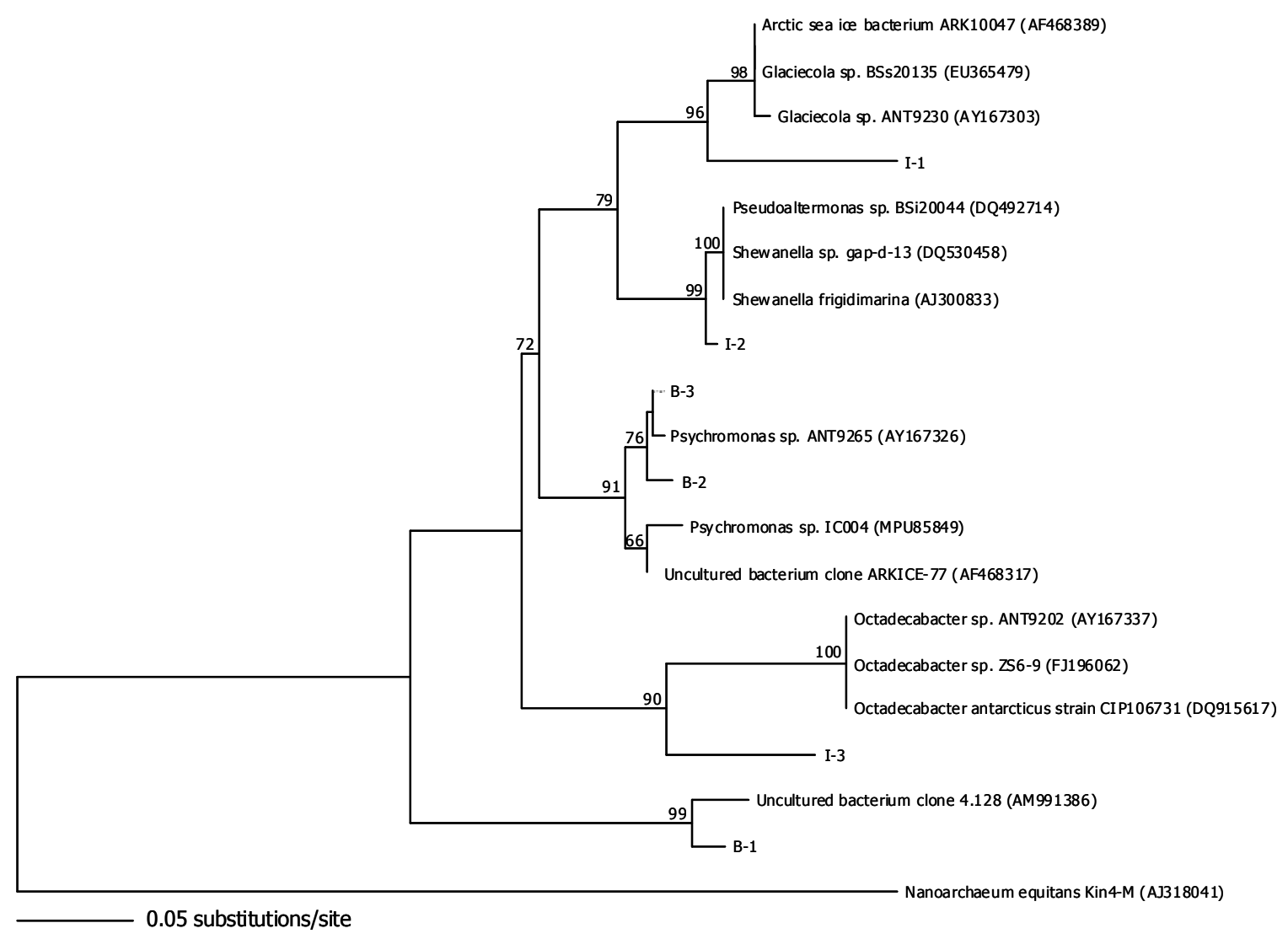

Figure 4.5: Neighbour-joining tree showing the relationship of 16S ribosomal DNA sequences of excised DGGE bands (152 bp) from bottom-ice (O'Brien Bay) and brine (Terra Nova Bay) together with nearest neighbours from the $\alpha$ and $\gamma$ subdivisions of the Proteobacteria. B-1, B-2, B-3 = excised brine bands displayed in Figure 4.2; I-1, I-2, I-3 = excised bottom-ice bands displayed in Figure 4.4. The accession numbers of the reference sequences used in the calculation are reported in parentheses. Maximum-likelihood bootstrap resampling values greater than 50\% (10,000 replicates) are indicated near the nodes. The $16 \mathrm{~S}$ rRNA gene sequence of Nanoarcheaum equitans was used as the outgroup. The scale bar represents 5\% estimated sequence divergence 
Table 4.2: Phylogenetic affiliation of sequences obtained from denaturing gradient gel electrophoresis (DGGE) bands with closest matches from BLAST search of the GenBank database. I-1, I-2, I-3 = excised brine bands displayed in Figure 4.2; B-1, B-2, B-3 =.excised bottom-ice bands displayed in Figure 4.4. Sequence similarity was calculated from 152 base pairs.

\begin{tabular}{|c|c|c|c|c|c|}
\hline Band & $\begin{array}{c}\text { Closest match } \\
\text { (environmental or culture) }\end{array}$ & $\begin{array}{c}\text { Sequence } \\
\text { similarity \% }\end{array}$ & $\begin{array}{l}\text { Taxonomic } \\
\text { Group }\end{array}$ & Source & $\begin{array}{c}\text { GenBank } \\
\text { accession } \\
\text { number }\end{array}$ \\
\hline B-1 & Uncultured bacterium clone 4.128 & 96.2 & Environmental & Arctic lake & AM991386 \\
\hline \multirow[t]{2}{*}{ B-2 } & Psychromonas sp. ANT9265 & 98.1 & $\begin{array}{l}\gamma \text {-Proteobacterial } \\
\text { Psychromonadaceae }\end{array}$ & Arctic/Antarctic pack ice & AY167326 \\
\hline & Uncultured bacterium clone ARKICE-77 & 96.8 & Environmental & Arctic/Antarctic pack ice & AF468317 \\
\hline B-3 & Psychromonas sp. ANT9265 & 100 & $\begin{array}{l}\gamma \text {-Proteobacterial } \\
\text { Psychromonadaceae }\end{array}$ & Arctic/Antarctic pack ice & AY167326 \\
\hline \multirow[t]{3}{*}{$\mathrm{I}-1$} & Glaciecola sp. BSs20135 & 90.5 & $\begin{array}{l}\gamma \text {-Proteobacterial } \\
\text { Alteromonadaceae }\end{array}$ & Arctic marine sediments & EU365479 \\
\hline & Arctic sea-ice bacterium ARK10047 & 90.5 & $\begin{array}{l}\gamma \text {-Proteobacterial } \\
\text { Alteromonadaceae }\end{array}$ & Arctic sea-ice & AF468389 \\
\hline & Glaciecola sp. ANT9230 & 90.5 & $\begin{array}{l}\gamma \text {-Proteobacterial } \\
\text { Alteromonadaceae }\end{array}$ & Arctic/Antarctic sea-ice & AY167303 \\
\hline \multirow[t]{3}{*}{$\mathrm{I}-2$} & Pseudoalteromonas sp. BSi20044 & 98.7 & $\begin{array}{l}\gamma \text {-Proteobacterial } \\
\text { Pseudoalteromonadaceae }\end{array}$ & Arctic sea-ice & DQ492714 \\
\hline & Shewanella frigidimarina LMG19867 & 98.7 & $\begin{array}{l}\gamma \text {-Proteobacterial } \\
\text { Shewanellaceae }\end{array}$ & Antarctic coastal seawater & AJ300833 \\
\hline & Shewanella sp. gap-d-13 & 98.7 & $\begin{array}{l}\gamma \text {-Proteobacterial } \\
\text { Shewanellaceae }\end{array}$ & Antarctic sea-ice & DQ530458 \\
\hline \multirow[t]{3}{*}{$\mathrm{I}-3$} & Octadecabacter sp. ZS6-9 & 90.5 & $\begin{array}{l}\alpha \text {-Proteobacterial } \\
\text { Rhodobacteraceae }\end{array}$ & Antarctic seawater & FJ196062 \\
\hline & Octadecabacter antarcticus CIP106731 & 90.5 & $\begin{array}{l}\alpha \text {-Proteobacterial } \\
\text { Rhodobacteraceae }\end{array}$ & NA & DQ915617 \\
\hline & Octadecabacter sp. ANT9202 & 90.5 & $\begin{array}{l}\alpha \text {-Proteobacterial } \\
\text { Rhodobacteraceae }\end{array}$ & Arctic/Antarctic pack-ice & AY167337 \\
\hline
\end{tabular}




\subsection{Discussion}

Diverse microbial communities are present in the brine inclusions and interstices of the sea-ice matrix that are integral to the energy base of the Southern Ocean (Garrison 1991). The positive correlation between Chl $a$ and bacterial abundance that has been periodically described in the literature is thought to indicate links within the microbial loop (Pedrós-Alió et al. 2002, Stewart \& Fritsen 2004), which may reflect the relative age of the sea-ice and synergistic effects of DOM availability and in situ ice temperature (Helmke \& Weyland 1995, Pomeroy \& Wiebe 2001, Stewart \& Fritsen 2004). Although a technique has been developed allowing the microbial community to be visualised within the three-dimensional framework of brine inclusions (Jung et al 2001), direct insight into the ecophysiology and trophic interactions of sea-ice microbes still requires the analysis of melted ice samples or extracted brine. The microcosm experiments performed in this study were primarily conducted to investigate the effect of microalgal photosynthetic metabolism on bacterial activity, growth and community structure. Given that the data are sourced from different locations and field seasons, the findings are considered simply within the context of observing microbial dynamics. Although we adopt the term 'microcosm', consideration must also be made that experimental replicates were 60 and $100 \mathrm{ml}$ due to the logistical constraints of deep-field Antarctic research. I therefore acknowledge that the association of microbes with a large plastic surface area ('bottle effect') may have influenced the results.

\subsubsection{Brine microcosm}

The abundance of bacteria in both the light/dark and dark treatments essentially doubled during the course of the experiment, most likely in response to the active supply of algal exudates (Figure 4.1). In contrast, the relatively minor changes in cell 
abundance between Days 1-9 for culture flasks spiked with DCMU is indicative of DOM limitation. Although the percentage of metabolically active brine bacteria (Table 4.1)(CTC+ cells) was considerably higher than the $2-10 \%$ level of activity typical of most marine systems (Bernard et al. 2000, Bernard et al. 2001, Schumann et al. 2003, Longnecker et al. 2005), the comparable activity among treatments on Day 9 was unexpected given the lack of bacterial growth in replicates spiked with DCMU. However, the similar end-point estimates of CTC+ cells are of interest, and highlight the potential for either the maintenance of intracellular activity without cell division, or variation between treatments with respect to microalgal growth and protistan herbivory.

Although rates of protistan grazing by heterotrophic flagellates and ciliates were not directly quantified in this study, changes in the concentration of Chl $a$ is possibly a useful proxy. In comparison to the pre-incubation level, Chl $a$ concentrations declined across all treatments by Day 9 in brine culture flasks (Table 4.1). This reduction was similar for the light/dark and dark treatments, which suggests a loss of microalgal cells through grazing rather than the bleaching of photosynthetic pigments in the light treatment, the accumulation of dead or degraded cells in the dark treatment, or photoadaptation of microalgal cells in either treatment. Assuming equal rates of herbivory among treatments, the significantly lower concentration of Chl $a$ in the DUMU treatment may indicate that microalgal growth during the course of the experiment was limited. Sustained metabolic activity in this treatment on Day 9 may thus be due to the photosynthate made available by the rupture and degradation of algal cells during grazing. Despite the implied herbivory, the higher Chl $a$ concentrations recorded in the light/dark and dark treatments suggests 
continued turnover of microalgal cells and the active production of exudates during the course of the experiment. Direct evidence for protistan grazing in the high-brine region of sea-ice is limited (but see Archer et al. 1996) but warrants further investigation as inferences can only be made through changes in the concentration of microalgal pigments which are sensitive to changes in the availability of light and nutrients.

\subsubsection{Bottom-ice microcosm}

Following the significant increase in abundance between Days 1-5, the concentration of bottom-ice bacteria declined dramatically in all culture flasks by Day 9 . For the DCMU and dark treatments this was to a level below the post-melt cell concentration (Figure 4.3). This decline in bacterial cells may indicate the presence of bacterivorous protists, and while this trend differs substantially from that of Giesenhagen et al. (1999) who reported an increase in both bacterial production and cell abundance during a 14-day multi-microcosm experiment that utilised pack-ice microbes, protistan grazing in the congelation layer of the ice profile has been documented by various authors (see Archer et al. 1996, Scott et al. 2001, Fiala et al. 2006).

A significant fraction of the microalgal biomass also appears to have been grazed during the course of the incubation, as shown by the reduction in Chl $a$ (Table 4.1). Although the growth of bacteria in the DCMU treatment was lower, the effect was less pronounced compared to the brine experiment, indicating a significantly higher concentration of DOM. In comparison to the cold, high-brine region of the ice, the congelation layer is characterised by favourable saline and temperature regimes and the increased availability of DOM and other nutrient pools. As a result, $50 \%$ of the 
observed abundance and $90 \%$ of the bacterial biomass occurs in the bottom $20 \mathrm{~cm}$ of fast-ice where bacteria have been observed as paired or dividing cells that can be 510 fold larger than the bacterioplankton in the underlying water column (Sullivan \& Palmisano 1984). As might be expected, given the favourable physicochemical environment, both the pre- and post-incubation estimates of bacterial metabolic activity were substantially higher in the bottom-ice microcosm compared to the brine microcosm (Table 4.1). Comparable estimates of CTC+ bacteria have previously been reported from this region of the sea-ice (Martin et al. 2008) and this may reflect the release of DOM during the melting process (Giesenhagen et al. 1999, Martin et al. 2009 accepted).

\subsubsection{Light vs. dark incubation?}

In a recent review of microbial carbon flux in the sea, Gasol et al. (2008) highlight the current ambiguity associated with measuring bacterial production (leucine and/or thymidine incorporation), given reports that both light or dark incubation conditions can stimulate or inhibit production. These authors recommend that dark and light incubations be run in parallel, as reported here. The variation observed in both microcosm experiments with respect to intracellular activity and growth of cultures maintained in the dark, or exposed to an arbitrarily derived light/dark cycle, was insignificant. The stimulus for growth in brine bacteria confined to the dark is particularly interesting, yet difficult to explain. The physiological mechanisms of dark survival in sea-ice algae remain poorly characterised and the extent to which microalgae continue to produce exudates during the metabolism of endogenous carbon reserves is not known. 


\subsubsection{DGGE analysis}

As a molecular genetic technique, DGGE is an established alternative to morphological-based identifications, particularly in the analysis of bacterial and archaeal assemblages (Casamayor et al. 2000, Gast et al. 2004). While issues associated with DNA extraction efficiency, rRNA gene copy number and PCR primer annealing efficiency are well described in the literature (see Reysenbach et al. 1992, Farrelly et al. 1995, for reviews), these biases may be considered less problematic in the present study given the experimental design involved short-term manipulation with an identical initial community composition. Only recently has a combination of primer sets been applied to the same microbial system to compare banding in DGGE gels (Sánchez et al. 2007). In the current study, derived phylotypes were optimised using the primer set secondarily favoured by these authors and reduced amplicon length was accepted as a trade-off for potentially maximising community variability. Despite phylogenetic information being sourced from only ca. $150 \mathrm{bp}$, excised DGGE bands showed acceptable (>90\%) similarity to $\alpha$-Proteobacteria sequences from polar regions, and high bootstrap support for these groupings was obtained in construction of a neighbour-joining tree (Table 4.2, Figure 4.5).

Cluster analysis revealed a relatively stable microbial community in the bottom-ice microcosm accompanied by only minor shifts in the composition of the bacterial assemblages with respect to treatment and time. In contrast, the variation in band patterns was more pronounced in the brine microcosm, and bacterial fingerprints associated with the DCMU treatment formed a distinct cluster within the UPGMA dendrogram. This shift in bacterial community composition combined with minimal 
changes in cell abundance during the incubation period provides useful insight into the link between sea-ice algae and bacterial metabolism. With respect to microbial dynamics, bacteria from the high-brine region of the ice profile were clearly responsive to changes in the availability of algal-derived photosynthate and restricting this important component of the DOM pool for even a short period of time had a significant influence on bacterial community structure.

The aim of this study was to determine whether microcosm simulations provide a useful insight into microbial loop dynamics within Antarctic sea-ice. For the first time, I provide evidence for the bacterial assimilation of algal-derived DOM by bacteria beyond the use of bulk comparisons. By restricting the supply of photosynthate with DCMU, the subsequent growth of bacterial cells was significantly restricted. This effect was most pronounced in the microbial community derived from the high-brine region of the ice which is typically characterised by low DOM. Although bacterial metabolic activity was lower than that observed for bottom-ice cells, these results suggest that DOM (and the concentration of microalgae) may have a greater influence on bacterial abundance than either low temperature or high salinity in this region of the ice. I also infer protistan grazing, which is integral to the microbial loop, but remains largely unstudied in the sea-ice system. A mechanistic understanding of productivity and trophodynamics in the Antarctic sea-ice ecosystem will ultimately require techniques that probe the spatial confines of the ice matrix, however results obtained here using the microcosm simulation technique are an important step towards achieving that goal. 


\subsection{Literature cited}

Ackley SF, Sullivan CW (1994) Physical controls on the development and characteristics of Antarctic sea ice biological communities - a review and synthesis. Deep-Sea Research 41: 1583-1604.

Archer SD, Leakey RJG, Burkill PH, Sleigh MA, Appleby CJ (1996) Microbial ecology of sea ice at a coastal Antarctic site: community composition, biomass and temporal change. Marine Ecology Progress Series 135: 179-195.

Azam F, Malfatti F (2007) Microbial structuring of marine ecosystems. Nature Reviews Microbiology 5: 782-791.

Azam F, Smith DC, Hollibaugh J.T. 1991. The role of the microbial loop in Antarctic pelagic ecosystems. Polar Research 10: 239-243.

Bernard L, Schäfer H, Joux F, Courties C, Muyzer G, Lebaron P (2000) Genetic diversity of total, active and culturable marine bacteria in coastal seawater. Aquatic Microbial Ecology 23: 1-11.

Bernard L, Courties C, Duperray C, Schäfer H, Muyzer G, Lebaron, P (2001) A new approach to determine the genetic diversity of viable and active bacteria in aquatic ecosystems. Cytometry 43: 314-321.

Casamayor EO, Schäfer H, Bańeras L, Pedrós-Alió C, Muyzer G (2000) Identification of and spatio-temporal differences between microbial assemblages from two neighboring sulfurous lakes: comparison by microscopy and denaturing gradient gel electrophoresis. Applied and Environmental Microbiology 66: 499-508.

Delille D, Fiala M, Rosiers C (1995) Seasonal changes in phytoplankton and bacterioplankton distribution at the ice-water interface in the Antarctic neritic area. Marine Ecology Progress Series 123: 225-233.

Ducklow H, Carlson C, Smith W (1999) Bacterial growth in experimental plankton assemblages and seawater cultures from the Phaeocystis antarctica bloom in the Ross Sea, Antarctica. Aquatic Microbial Ecology 19: 215-227.

Evans CA, O'Reilly JE, Thomas JP (1987) A handbook for the measurement of chlorophyll a and primary production. College Station,Texas A\&M University, 114p.

Farrelly V, Rainey FA, Stackebrandt E (1995) Effect of genome size and rRNA gene copy number on PCR amplification of 16S rRNA genes from a mixture of bacterial species. Applied and Environmental Microbiology 61: 2789-2801.

Fiala M, Kuosa H, Kopczyńska EE, Oriol L, Delille D (2006) Spatial and seasonal heterogeneity of sea ice microbial communities in the first-year ice of Terre Adélie area (Antarctica). Aquatic Microbial Ecology 43: 95-106.

Francoeur SN, Johnson AC, Kuehn KA, Neely RK (2007) Evaluation of the efficacy of the photosystem II inhibitor DCMU in periphyton and its effects on nontarget microorganisms and extracellular enzymatic reactions. Journal of the North American Benthological Society 26: 633-641.

Garrison DL (1991) Antarctic sea ice biota. American Zoologist 31: 17-33.

Gasol JM, Pinhassi J, Alonso-Sáez L, Ducklow H, Herndl GJ, Koblížek M, Labrenz M, Luo Y, Morán XAG, Reinthaler T, Simon M (2008) Towards a better understanding of microbial carbon flux in the sea. Aquatic Microbial Ecology 53: 21-38.

Gast RJ, Dennett MR, Caron DA (2004) Characterization of protistan assemblages in the Ross Sea, Antarctica, by denaturing gradient gel electrophoresis. Applied and Environmental Microbiology 70: 2028-2037.

Grossi SM, Kottmeier ST, Sullivan CW (1984) Sea ice microbial communities III. Seasonal abundance of microalgae associated bacteria in McMurdo Sound, Antarctica. Microbial Ecology 10: 231-242.

Helmke E, Weyland H (1991) Bacteria in sea ice and underlying water of the eastern Weddell Sea in midwinter. Marine Ecology Progress Series 117: 141-163. 
Junge K, Krembs C, Deming J, Stierle A, Eicken H (2001) A microscopic approach to investigate bacteria under in situ conditions in sea-ice samples. Annals of Glaciology 33: 304-310.

Karl DM (2003) Determination of in situ microbial biomass, viability, metabolism, and growth In: Poindexter JS, Leadbetter ER (eds) Bacteria in nature volume 2: methods and special applications in bacterial ecology. Kluwar Academic Publishers Group, p 81-176.

Kottmeier ST, Sullivan CW (1987) Late winter primary production and bacterial production in sea ice and seawater west of the Antarctic Peninsula. Marine Ecology Progress Series 36: $287-298$.

Kottmeier ST, Sullivan CW (1990) Bacterial biomass and production in pack ice of Antarctic marginal ice edge zones. Deep-Sea Research 37: 1311-1330.

Kottmeier ST, McGrath Grossi S, Sullivan CW (1987) Sea ice microbial communities. VIII. Bacterial production in annual sea ice of McMurdo Sound, Antarctica. Marine Ecology Progress Series 35: 175-186.

Legendre L, Ackley SF, Dieckmann, GS, Gulliksen B, Horner R, Hoshiai T, Melnikov IA, Reeburgh WS, Spindler M, Sullivan CW (1992) Ecology of sea ice biota. 2. Global Significance. Polar Biology 12: 429-444.

Longnecker K, Sherr BF, Sherr EB (2005) Activity and phylogenetic diversity of bacterial cells with high and low nucleic acid content and electron transport system activity in an upwelling ecosystem. Applied and Environmental Microbiology 71: 7737-7749.

Martin A, Hall JA, Ryan KG (2009) Low salinity and high UV-B radiation reduce single-cell activity in Antarctic sea ice bacteria. In review: Applied and Environmental Microbiology.

Martin A, Hall JA, O’Toole R, Davy SK, Ryan KG (2008) High single-cell metabolic activity in Antarctic sea ice bacteria. Aquatic Microbial Ecology 52: 25-31.

Pedrós-Alió C, Vaqué D, Guixa-Boisereu N, Gasol, JM (2002) Prokaryotic plankton biomass and heterotrophic production in western Antarctic waters during the 1995-1996 austral summer. Deep-Sea Research 49: 805-825.

Pomeroy LR, Wiebe WJ (2001 Temperature and substrates as interactive limiting factors for marine heterotrophic bacteria. Aquatic Microbial Ecology 23: 187-204.

Reysenbach AL, Giver LJ, Wickham GS, Pace NR (1992) Differential amplification of rRNA genes by polymerase chain reaction. Applied and Environmental Microbiology 58: 3417-3418.

Sánchez O, Gasol JM, Massana R, Mas J, Pedrós-Alió C (2007) Comparison of different denaturing gradient gel electrophoresis primer sets for the study of marine bacterioplankton communities. Applied and Environmental Microbiology 73: 59625967.

Schäfer H, Muyzer G (2001) Denaturing gradient gel electrophoresis in marine microbial ecology. In: Paul J (ed) Methods in Microbiolgy, vol 30 marine microbiology. Academic Press, $\mathrm{p}$ 425-468.

Scott FJ, Davidson AT, Marchant HJ (2001) Grazing by the Antarctic sea-ice ciliate Pseudocohnilembus. Polar Biology 24: 127-131.

Shumann R, Schiewer U, Karsten U, Rieling T (2003) Viability of bacteria from different aquatic habitats. II. Cellular fluorescent markers for membrane integrity and metabolic activity. Aquatic Microbial Ecology 32: 137-150.

Staley JT, Junge K, Deming J (2002) And some like it cold: sea ice microbiology. In: Staley JT, Reysenbach A-L (eds) Biodiversity of Microbial Life. Wiley-Liss Inc., New York, $552 \mathrm{p}$.

Stewart FJ, Fritsen CH (2004) Bacteria-algae relationships in Antarctic sea ice. Antarctic Science 16:143-156.

Sullivan CW, Palmisano AC (1984) Sea ice microbial communities: Distribution, abundance, and diversity of ice bacteria in McMurdo Sound, Antarctica, in 1980. Applied and Environmental Microbiology 47: 788-795.

Thomas DN, Dieckmann GS (2002) Antarctic sea ice - a habitat for extremophiles. Science 295: 641-644. 


\section{CHAPTER 5}

In situ response of sea-ice microbes to habitat variability: insight into community dynamics or just another 'flippin' ice core'?

\subsection{Abstract}

Sea-ice microbial communities are integral to production and trophodynamics in icecovered regions of the Southern Ocean, however relatively few studies have characterised the vertical heterogeneity of the microbial biomass or examined how habitat variability influences in situ community dynamics. I examined the response of sea-ice microbes to key physicochemical variables by conducting an 18-day reciprocal transplant experiment within Antarctic sea-ice. A series of cores (with experimental controls) were extracted from $2.6 \mathrm{~m}$ annual fast-ice and reinserted into the ice matrix upside down to expose resident microbial assemblages to a significantly different light, temperature, and salinity regime. A series of loggers were imbedded within the ice to record light and temperature. In situ variation with respect to the abundance and community composition of bacteria, microalgae and protozoa was examined at three regions within the ice (top, middle and bottom) and analysed using both uni- and multivariate techniques. Results indicate that microbial assemblages are functionally similar, but not functionally redundant with respect to trophic interactions. A positive growth response and shift in community composition was observed in microalgae moved from the top to the bottom of the ice, but significant bleaching of photosynthetic pigments resulted in zero net growth for bottom-ice communities exposed to the surface. In general, sea-ice bacteria were 
more resilient to the disturbed environment, however limited assimilation of algalderived DOM by bacteria in the flipped cores resulted in a 'malfunction' of the microbial loop. Sea-ice microbial communities are finely attuned to variation in the in situ physicochemical environment and the reciprocal transplant design provides a unique insight into community dynamics.

\subsection{Introduction}

A mechanistic understanding of productivity and trophodynamics in the Antarctic sea-ice ecosystem, and the development of prognostic models to qualify the resilience of the microbial community to climate change, pose a significant challenge to microbial ecologists. This is due not only to the ephemeral nature of sea-ice and the complex suite of physicochemical variables that stratify the ice matrix (Arrigo \& Sullivan 1992, Ackley \& Sullivan 1994, McMinn et al. 1999a), but also to the concomitant task of linking spatial and temporal variability with the taxonomic diversity and functional capabilities of ice-associated microbes (Mock \& Thomas 2005, Murray \& Grzymski 2007).

Although the annual circumpolar expansion of sea-ice around Antarctica modulates the exchange of heat and moisture between the atmosphere and ocean and severely restricts the penetration of solar radiation (Delille 1992, Legendre et al. 1992), seaice provides a stable platform for the colonisation and growth of a diverse assemblage of psychrophilic microbes including bacteria, microalgae and protozoa (Garrison 1991, Archer et al. 1996, Fritsen et al. 2001, Gowing et al. 2004, Garrison et al. 2005). During initial ice formation in the austral autumn planktonic organisms are scavenged from the water column, and as the ice develops these microbes are 
concentrated into a closed or semi-closed labyrinth of brine channels and pores within the ice that vary in size from micrometers to several millimetres (Garrison 1991, Thomas \& Dieckmann 2002, Arrigo \& Thomas 2004). Sea-ice is also characterised by steep vertical gradients in light, temperature, salinity, and nutrient concentrations (Arrigo \& Sullivan 1992, McMinn et al. 1999a). Although the initial inoculum comprises a diverse group of mixed species, only a subset possess the physiological and biochemical mechanisms that allow adaptation to the ice matrix (Deming 2002, Thomas \& Dieckmann 2002). Despite these strong selection processes, microbial communities are present in discrete assemblages throughout the ice profile.

The most conspicuous ice-bound organisms are microalgae, and research efforts have historically focused on the composition, physiology, and ecology of the pennate diatoms that dominate fast-ice assemblages (e.g. Kottmeier \& Sullivan 1988, Garrison 1991, Arrigo et al. 1998, McMinn et al. 2000, Ryan et al. 2002). Microalgal communities contribute between $10-28 \%$ of the total primary production in icecovered regions of the Southern Ocean (Legendre et al. 1992, Arrigo et al. 1997) and over $90 \%$ of this biogenic carbon is produced within first-year ice and approximately $60 \%$ during the austral spring (November-December)(Arrigo \& Thomas 2004).

During the seasonal development of the microbial community, microalgal photosynthetic metabolism is often spatially and temporally correlated with the growth of heterotrophic bacteria (Grossi et al. 1984, Delille et al. 1995, Stewart \& Fritsen 2004). Secondary bacterial production is stimulated by the concentration of dissolved organic matter (DOM) within the ice and can reach up to $10 \%$ of primary 
production. In the polar winter, where low light restricts photoautotrophy, the consumption of organic carbon by bacteria can exceed primary production (Thomas \& Dieckmann 2002, Mock \& Thomas 2005). The in situ production of algal-derived photosynthate (Grossi et al. 1984) and release of exopolymeric substances (EPS)(Krembs et al. 2002, Meiners et al. 2004), as well as the rupture and degradation of algal cells during protozoan grazing (Günther et al. 1999), contribute significantly to the pool of DOM available for bacterial metabolism. In return, bacteria are thought to provide recycled inorganic nutrients and/or vitamins that are required for continued algal growth (Kottmeier et al. 1987, Kottmeier \& Sullivan, 1990, Archer et al. 1996). Covariation between the autotrophic and heterotrophic biomass is integral to the microbial loop (Azam et al. 1991, Azam \& Malfatti 2007), but the variability associated with this dynamic is not well understood. While coupling is likely to reflect factors such as the relative age of the sea-ice and synergistic effects of DOM and in situ temperature (Helmke \& Weyland 1995, Pomeroy \& Wiebe 2001, Thomas et al. 2001, Stewart \& Fritsen 2004), this metabolic pathway is complicated by factors such as regional and annual variability in sea-ice conditions and the potential for microalgae to release bactericidal and/or bacteriostatic compounds (Monfort et al. 2000, Mock \& Thomas 2005, Pusceddu et al. 2009).

The links to higher trophic levels within the microbial loop are equally equivocal. The consumption of bacteria by protozoa such as flagellates and ciliates may cycle as much as $20-30 \%$ of the ice-bound primary production to higher trophic levels (Delille et al. 2002, Staley et al. 2002), but the exact relationships between these organisms and rates of carbon transfer are not well defined (Archer et al. 1996, 
Stewart \& Fritsen 2004, Fiala et al. 2006). Despite this level of uncertainty, the microscopic fraction of the sea-ice community is known to be a concentrated food source for crustaceous zooplankton such as the Antarctic krill Euphausia superba (Daly 1990, Kottmeier and Sullivan 1990), and sea-ice microbes are likely to provide inocula for bloom events at the receding ice edge in the austral summer (Kottmeier \& Sullivan 1988, Giesenhagen et al. 1999, Lizotte 2001, Arrigo \& Thomas 2004).

Despite being integral to the energy base of the Southern Ocean, relatively few studies have characterised the vertical heterogeneity of the microbial community (Archer et al. 1996, Delille et al. 2002, Garrison et al. 2005) or examined how physicochemical variables influence in situ community composition and trophodynamics (but see Grossmann \& Gleitz 1993, McMinn et al. 2000). In contrast, microbial activity and the response to experimental stimuli has been well characterised from melted ice cores and extracted brine (eg. Ryan et al. 2004, Ralph et al. 2007, Martin et al. 2008). Unfortunately this process destroys the internal micro-environment within the ice and homogenises the spatial arrangement of microbes and DOM which may influence microbial activity (Giesenhagen et al. 1999, Junge et al. 2001, Martin et al. 2009).

In this study I conducted an $18 \mathrm{~d}$ reciprocal transplant experiment and examined the in situ response of sea-ice microbes to key physicochemical variables. Specifically, I extracted a series of ice cores from annual Antarctic fast-ice and reinserted them back into the matrix upside down. Resident microbial communities were thus exposed to a significantly different microhabitat with respect to light, temperature, salinity and the availability of DOM. I quantified variation in the relative abundance 
of the bacteria, microalgae and protozoa present in the ice and documented temporal change with respect to community composition.

\subsection{Materials and methods}

\subsubsection{Ice cores}

Sea-ice microbes were extracted on two occasions from $2.6 \mathrm{~m}$ fast-ice during the austral spring of 2006 at Terra Nova Bay, Antarctica ( $\left.74^{\circ} 38^{\prime} \mathrm{S}, 164^{\circ} 13^{\prime} \mathrm{E}\right)$. On $15^{\text {th }}$ November a series of ice cores were drilled within a $3 \mathrm{~m}$ radius using a Kovaks (Kovaks,USA) ice corer (130 mm diameter, $1600 \mathrm{~mm}$ length). To minimise light shock, ice cores were removed under a black sheet. Of the nine extracted cores, three were immediately reinserted upside down (flipped) to provide the experimental treatment, three were replaced in their original orientation (disturbed control) to control for the process of core removal and shearing of the ice, and three were used to establish an initial baseline of microbial abundance and diversity $\left(\mathrm{T}_{0}\right)$ The exact position of each reinserted core was marked precisely and snow cover at the site was negligible. After $18 \mathrm{~d}$, the flipped and disturbed control ice cores were carefully reextracted from the sea-ice using the Kovaks ice corer. To control for potential change in the structure of the sea-ice microbial community during the course of the experiment, three further cores (undisturbed control) were collected from the same region.

Microbes were extracted by removing $100 \mathrm{~mm}$ long sections of each core at three distinct regions: top $(0-0.1 \mathrm{~m})$, middle $(1.25-1.35 \mathrm{~m})$ and bottom $(2.5-2.6 \mathrm{~m})$. The central inner region of each core section was removed (40 x $40 \times 100 \mathrm{~mm})$ using sterile technique and melted into three times the volume of $0.22 \mu \mathrm{m}$-filtered seawater 
$\left(35 \%,-1.8^{\circ} \mathrm{C}\right)$, under low light $\left(<1 \mu \mathrm{mol}\right.$ photons $\left.\mathrm{m}^{-2} \mathrm{~s}^{-1}\right)$, in sterile containers (Ryan et al. 2004).

\subsubsection{Physical measurements}

Photosynthetically active radiation (PAR) was measured by embedding four Photosynthetic Light Smart Sensors (Microdaq, USA) within the ice at the following depths: surface, $0.5 \mathrm{~m}, 1.2 \mathrm{~m}$ and $1.8 \mathrm{~m}$. Data were recorded at $5 \mathrm{~min}$ intervals and stored in a Micro Station Data Logger (Microdaq, USA). Temperature was measured using custom made loggers that were calibrated to record every $20 \mathrm{~min}$ and positioned as follows: surface, $0.05 \mathrm{~m}, 0.50 \mathrm{~m}, 0.95 \mathrm{~m}, 1.4 \mathrm{~m}, 1.85 \mathrm{~m}, 2.3 \mathrm{~m}$ and 2.65 m (in the water column). Salinity was derived using the average temperature at each depth of interest using the conversion of Cox \& Weeks (1986)

\subsubsection{Chlorophyll $a$}

A 100-300 ml subsample of each melted ice core section was filtered onto a $47 \mathrm{~mm}$ $\mathrm{GF} / \mathrm{F}$ filter and extracted in $10 \mathrm{ml}$ of methanol for 12 hours in the dark at $4^{\circ} \mathrm{C}$. Chlorophyll $a(\mathrm{Chl} a)$ was then measured on a digital fluorometer (Turner 10AU, Australia) using the acidification method of Evans et al. (1987).

\subsubsection{Enumeration and identification of microalgae and protozoa}

A $10 \mathrm{ml}$ subsample of each core section was fixed in $0.5 \%$ gluteraldehyde and stored at $4^{\circ} \mathrm{C}$ until return to New Zealand. A minimum of 200 cells per sample were identified and counted on a Zeiss inverted microscope using a specially designed settling chamber and phase contrast optics. Depending on the concentration of cells, this required examining between one and six $0.5 \mathrm{ml}$ aliquots for each core section. 


\subsubsection{Enumeration of bacteria}

A $5 \mathrm{ml}$ subsample of each core section were fixed in $0.05 \%$ gluteraldehyde and stored frozen at $-20^{\circ} \mathrm{C}$ until return to New Zealand. Enumeration of bacterial cells was performed using a Becton Dickinson FACScan flow cytometer equipped with a $15 \mathrm{~mW}, 488 \mathrm{~nm}$, air-cooled argon ion laser and standard filter setup. Initial instrument calibration was performed using FACScomp software in conjunction with Becton Dickinson CaliBRITE reference beads. To avoid coincidence, samples were run at a medium flow rate with less than 1,300 events per second. CellQuest software (Becton Dickinson, USA) was used for all sample and data analyses. Samples were thawed and $500 \mu \mathrm{l}$ was diluted with $2 \mathrm{ml}$ of $0.22 \mu \mathrm{m}$-filtered deionised water (required for high salinity samples, but standardised across all samples) and stained with $2.5 \mu \mathrm{l}$ of SYTO 13 (Molecular Probes, USA) for $10 \mathrm{~min}$ (in the dark at ambient temperature). TruCount beads (Beckton Dickinson, USA) were added to each sample to accurately calculate the volume of sample analysed. Bacterial data were typically collected for $2 \mathrm{~min}$ (acquisition of 250 TruCount beads) and cell populations were identified from bivariate plots of green fluorescence (FL1) vs. SSC (side scatter).

For the molecular analysis of bacterial populations, approximately $300 \mathrm{ml}$ of each melted core section was concentrated onto a $0.22 \mu \mathrm{m}$-pore size $47 \mathrm{~mm}$ Millipore filter using vacuum filtration and stored at $-80^{\circ} \mathrm{C}$ until return to New Zealand. Sterile technique was maintained throughout this procedure. 


\subsubsection{Nucleic acid extraction and PCR amplification of bacterial 16S rRNA genes}

Genomic DNA was extracted from the bacteria on each filter using a phenol/chloroform/isoamyl alcohol solution and precipitated in ethanol as described by Schäfer \& Murzer (2001). Primers 357F (CCT ACG GGA GGC AGC AG) and 518R (ATT ACC GCG GCT GCT GG) were used to amplify a 194 bp 16S rRNA fragment targeting the V3 region (Murray et al. 1996). An additional GC-rich sequence of 40 nucleotides (GC-clamp) was added to the $5^{\prime}$ ' end of primer $357 \mathrm{~F}$. PCR amplifications were performed using illustra PuReTaq Ready-To-Go PCR beads (GE Healthcare, UK) with 1-3 $\mu$ l of DNA template (final reaction volume 25 $\mu 1)$. Temperature-cycling was performed using an Eppendorf Thermal Cycler using the following conditions: initial denaturation at $94^{\circ} \mathrm{C}$ for $5 \mathrm{~min} ; 10$ touchdown cycles of denaturation (at $94^{\circ} \mathrm{C}$ for $1 \mathrm{~min}$ ), annealing (for $1 \mathrm{~min}, 65-55^{\circ} \mathrm{C}$ decreasing $1^{\circ} \mathrm{C}$ each min) and extension (at $72^{\circ} \mathrm{C}$ for $3 \mathrm{~min}$ ); 20 standard cycles (denaturing at $94^{\circ} \mathrm{C}$ for $1 \mathrm{~min}$, annealing at $55^{\circ} \mathrm{C}$ for $1 \mathrm{~min}$ and extension at $72^{\circ} \mathrm{C}$ for $3 \mathrm{~min}$ ) and a final extension at $72^{\circ} \mathrm{C}$ for $5 \mathrm{~min}$. PCR products were quantified by agarose gel electrophoresis using Hyperladder I (Bioline, UK).

\subsubsection{DGGE analysis of 16S rRNA gene fragments}

Denaturing gradient gel electrophoresis (DGGE) was performed using a D-Code ${ }^{\mathrm{TM}}$ Universal Mutation Detection System (Bio-Rad, USA). Approximately 500 ng of PCR product from each sample was loaded on a $8 \%$ (wt/vol) polyacrylamide gel (acrylamide and N,N'-methylene bisacrylamide at a ratio of 37:1) with a denaturing gradient that ranged from 40 to $70 \%$ (where $100 \%$ is defined as $7 \mathrm{M}$ urea and $40 \%$ deionized formamide). Gels were run for 18 hours at a constant voltage of $100 \mathrm{~V}$ at 
$60^{\circ} \mathrm{C}$ in $1 \mathrm{x}$ TAE buffer $(40 \mathrm{mM}$ Tris [pH 7.4], $20 \mathrm{mM}$ sodium acetate, $1 \mathrm{mM}$ EDTA). Gels were subsequently stained with a 1:10,000 dilution of SYBR Gold (Molecular Probes, USA) for $30 \mathrm{~min}$, rinsed, and visualised under UV light. Cluster analysis of DGGE band patterns was performed using BioNumerics (Applied Maths, Belgium). Patterns were compared using the Dice similarity coefficient and UPGMA (unpaired pair-wise grouping with mathematical averages) to generate dendrograms.

\subsubsection{Sequencing and comparative sequence analysis}

To obtain sequence information, 14 bands of interest were excised from DGGE gels using sterile razor blades and eluted in $500 \mu \mathrm{l}$ of PCR-grade water for $48 \mathrm{hr}$. A total of $2 \mu \mathrm{l}$ of the eluate was used for re-amplification with the original primer set. A portion of the PCR product of the second amplification was reanalysed by DGGE to verify the correct band position. PCR products were then purified using Exo-SAP IT (USB Corporation, USA) and quantified in an agarose gel using the Hyperladder I molecular size standard (Bioline, UK).

PCR products were sequenced using the BigDye terminator ready reaction cycle sequencing kit (Version 3.1) using both forward and reverse primers. Sequencing reactions were analysed on an ABI3730 Genetic Analyser and sequences were compared with the GenBank database using BLAST to obtain the closest bacterial matches. The partial and complete 16S rRNA gene sequences were then aligned using CLUSTAL W (Thompson et al. 1994), implemented in Geneious (Version 4.5.1, Biomatters). The fragment used for analysis after the removal of primer sequences was $160 \mathrm{bp}$. A distance tree was constructed in PAUP* (Version 4b10, Swofford 2002) using the neighbour-joining algorithm with Jukes-Cantor distances. 
The dataset was re-sampled and analysed 10,000 times to obtain bootstrap values. The partial environmental 16S rRNA gene sequences recovered in this study will be deposited in the GenBank nucleotide sequence database.

\subsubsection{Statistical analyses}

\subsubsection{Univariate analysis}

To examine changes in the relative abundance of microalgae, bacteria, and the concentration of Chl $a$ in core sections of the flipped treatment, SYSTAT (Version 12.0, SPSS) was used to perform a series of comparisons with the control treatments using one-way analysis of variance (ANOVA). For brevity, analysis and reference to microalgae also includes the limited number of protozoa that were observed in this study. Microalgae present in the top sections of the undisturbed control cores were excluded from the analysis due to unusually high cell counts (attributed to experimental handling error). Linear regression was used to correlate the abundance of bacteria and microalgae in control treatment cores and also the flipped treatment using SIGMAPLOT (Version 8.0, SPSS).

\subsubsection{Multivariate analysis}

For multivariate analysis, microalgal count data (including protozoa) were standardised by sample totals so that the relative abundance values were comparable across different cores. Standardised values ranged from zero to approximately 70 and were square-root transformed to balance the relative contribution of variables on different scales (Clarke \& Green 1988, Clarke \& Warwick 2001). Multivariate analyses were performed on the basis of a dissimilarity matrix among ice cores (30 taxa, 36 core sections), obtained using the Bray-Curtis measure (Bray \& Curtis 
1957). The rank dissimilarities in composition and relative abundance among the assemblages in different treatments were visualised using non-metric multidimensional scaling (MDS) on the distances among centroids (in the Bray-Curtis space) from the $n=3$ cores per treatment.

Permutational distance-based MANOVA (PERMANOVA, Anderson 2001, McArdle $\&$ Anderson 2001) was used to analyse the full $(30 \times 36)$ resemblance matrix on the basis of a two-way experimental design, with $P$-values obtained using 9,999 permutations of the raw data (Manly 2006). The experimental design consisted of two factors: Treatment, a fixed factor with $a=4$ levels: time zero $\left(\mathrm{T}_{0}\right)$, undisturbed control (UC), disturbed control (DC), and flipped cores (F); and Section (Se), a fixed factor with $b=3$ levels: top (T), middle (M) and bottom (B). Three contrasts were of particular interest a priori: (i) the contrast of the time zero cores versus the undisturbed control cores (to assess temporal change from the first time of sampling to the second); (ii) the contrast of the disturbed control cores versus the time zero and undisturbed control cores (to assess effects of disturbance); and (iii) the contrast of flipped cores versus all other treatments.

Banding patterns of bacterial phylotypes were compared using the Dice (Sørensen) similarity measure. This measure is equivalent to the Bray-Curtis measure calculated on presence-absence data and, as such, measures the percent similarity among communities in terms of the composition of phylotypes only. This resemblance matrix was analysed using the same multivariate techniques (i.e., MDS of distances among Treatment $\times$ Section centroids and PERMANOVA with contrasts), as described above for the microalgal community. 
To examine the relationship between abundance and diversity, bacteria, microalgae, and Chl $a$ were contrasted with three indices of diversity: the richness of bacterial phylotypes, and for microalgae both richness and Simpson's evenness $\left(1-\lambda^{\prime}\right)$. The distribution of each of these six variables was examined and abundance measurements were transformed to natural logs to achieve approximate normality. PERMANOVA (with relevant contrasts, as described above) was done on the Euclidean distance matrix calculated from the normalised variables. A principal component analysis (PCA) was performed to visualise overall patterns among variables. This analysis was subsequently repeated without the flipped treatment, to better examine potential patterns in these variables among core sections (top, middle and bottom).

A permutational test of dispersion (PERMDISP, Anderson 2006) was used to formally compare the relative dispersions among samples from the top, middle or bottom of the ice cores (excluding the flipped treatments), on the basis of the Dice (Sørensen) similarity measure for microalgae and also for bacterial communities. A MDS plot was used to visualise patterns in relative dispersion among sample units among the three groups on the basis of this measure.

\subsection{Results}

\subsubsection{Physical measurements}

Light, temperature and derived salinity varied significantly within the sea-ice profile (Figure 5.1). Mean in situ temperatures ranged from $-6.8^{\circ} \mathrm{C}(0.05 \mathrm{~m})$ to $-4.4^{\circ} \mathrm{C}(1.85$ $\mathrm{m}$ ) and light varied between $564 \mu \mathrm{mol}$ photons $\mathrm{m}^{-2} \mathrm{~s}^{-1}$ (surface) and $1.6 \mu \mathrm{mol}$ photons 
$\mathrm{m}^{-2} \mathrm{~s}^{-1}(1.85 \mathrm{~m})$. Temporal variation was evident in the penetration of light to $0.5 \mathrm{~m}$ and $1.2 \mathrm{~m}$ within the ice and for temperatures recorded at $0.05 \mathrm{~m}, 0.50 \mathrm{~m}$, and 0.95 m. Maximum light and temperature levels at these depths were recorded at solar noon on days with limited cloud cover. Variation in the data collected by loggers embedded below $1.8 \mathrm{~m}$ was minimal (Figure 5.1).

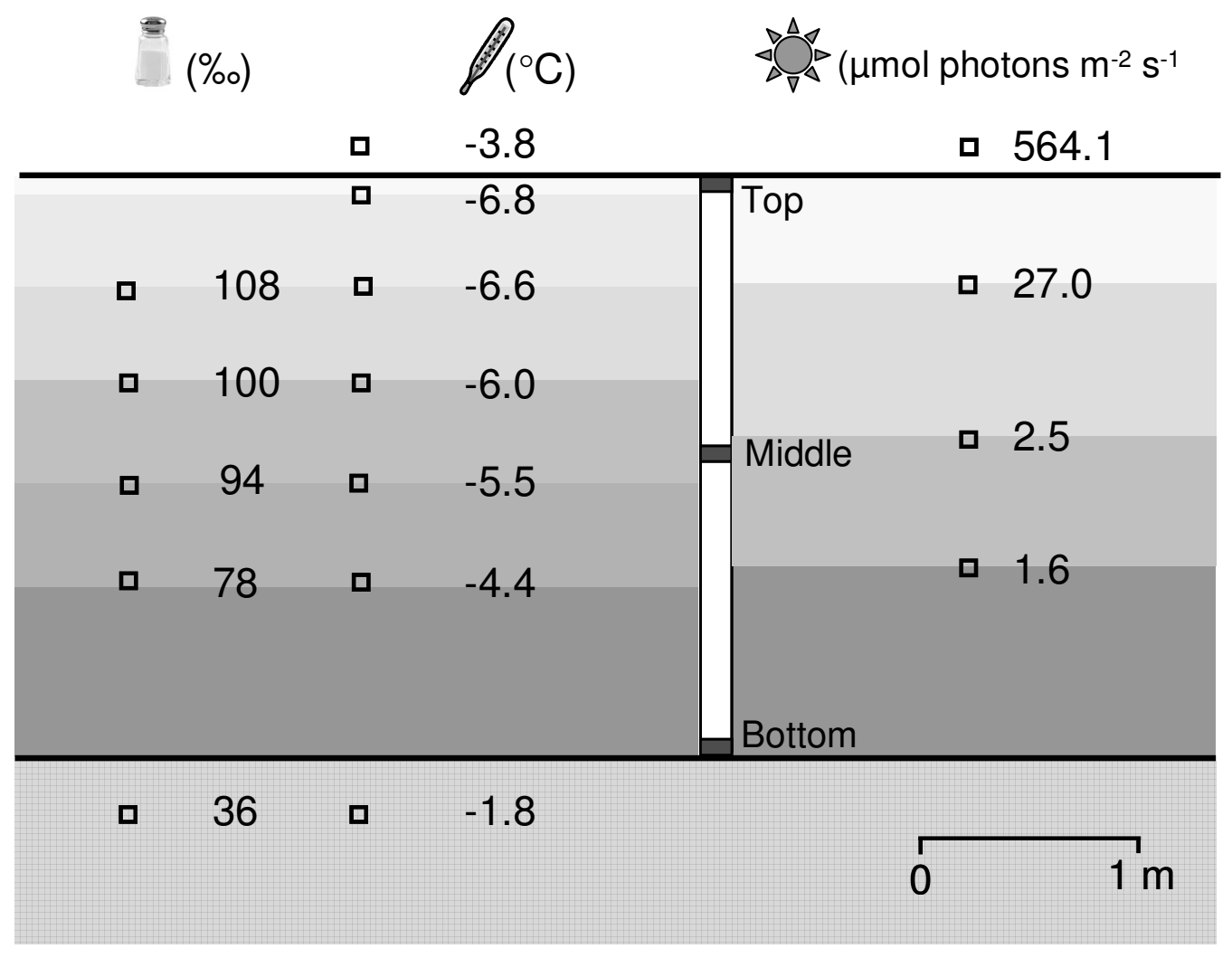

Figure 5.1: Schematic representation of light and temperature loggers deployed in annual fast ice at Terra Nova Bay, Antarctica, between $15^{\text {th }}$ November and $3^{\text {rd }}$ December 2006. Light data were collected every $5 \mathrm{~min}$ and temperature data were collected every 20 min. Data are mean values recorded over $18 \mathrm{~d}$. Salinity was derived from the mean temperature.

\subsubsection{Distribution and abundance of sea-ice microbes}

Microbes were present in the top, middle and bottom sections of all 12 extracted ice cores. At the start of the experiment $\left(\mathrm{T}_{0}\right),>80 \%$ of the microbial cells and $>99 \%$ of 
the Chl $a$ was concentrated in the bottom $100 \mathrm{~mm}$ of each core (Figure 5.2). This trend was still evident in the undisturbed (UC) and disturbed (DC) control treatments following 18 days of exposure to ambient conditions.

Changes in the relative abundance of sea-ice microbes and concentration of Chl $a$ in the flipped cores was examined by a series of comparisons with the three control treatments (Table 5.1). The abundance of microalgae originally at the bottom of the ice profile and flipped to the top (B-T) was not significantly different to the number of cells observed in the bottom sections of the control cores. However, the Chl $a$ in the top of the flipped cores was significantly lower compared to the controls (Figure 5.2a, Table 5.1, $P<0.01)$. For microalgae moved from the surface to the bottom of the ice (T-B) there was a significant increase in both the abundance of cells (Figure 5.2b, Table 5.1, $P=0.02$ ) and concentration of Chl $a$ (Figure 5.2a, Table 5.1, $P$ $<0.01)$. There was no significant difference among treatments with respect to middle core sections for either microalgae or $\mathrm{Chl} a$.

For bottom-ice bacteria exposed to the surface of the ice profile (B-T), there was no significant change in the abundance of cells with respect to the top sections of control cores after 18 days. The abundance of near-surface bacteria exposed to the ice/seawater interface (T-B) did not differ significantly from the bottom sections of the control cores and there was no difference in the abundance of bacteria in the mid core sections for any treatment. However an increase in bacteria was observed in the bottom section of both control treatments compared to the time zero treatment (Figure 5.2, Table 5.1, $P=0.03$ ). 
Regression analysis of the three control treatments showed a strong positive relationship between the abundance of microalgae and bacteria in the top, middle and bottom sections of the 9 control cores $(F=49.947, \mathrm{df}=1, P=<0.001$, Figure 5.3a). Coupling between the algal and bacterial biomass was still evident in the sections of flipped cores, but the relationship was not as strong $(F=6.9459, \mathrm{df}=1, P=0.033$, Figure 5.2b).

\subsubsection{Community composition}

There was a significant effect of flipping ice cores on the structure of microalgal communities, which was indicated by the significant F- vs- $\left\{\mathrm{DC}, \mathrm{UC}, \mathrm{T}_{0}\right\} \times \mathrm{Se}$ interaction term in the PERMANOVA (Table 5.2a, Table 5.3). There was no effect on community structure of either temporary core removal or time between sampling events (i.e., both the DC- $v s-\left\{\mathrm{UC}, \mathrm{T}_{0}\right\} \times \mathrm{Se}$ and the $\mathrm{UC}-v s-\mathrm{T}_{0} \times \mathrm{Se}$ interaction terms were non-significant, $P>0.50$ ). This interaction was also evident in patterns shown in the MDS plot (Figure 5.4). Microalgae present in the top of the control cores generally occurred towards the left of the diagram, and those from the bottom aligned towards the lower right. Cells present in the middle section were generally oriented in between. For cores in the flipped treatment, microalgae that were initially at the top of the ice profile were found to be similar to assemblages found at the bottom of the control cores (T-B) (Figure 5.4). Specific pair-wise comparisons indicated that microalgal communities originally at the top of flipped cores became somewhat like communities at the bottom of the control cores $(P=0.059)$, while the algal community originally at the bottom of flipped cores (B-T) were similar to the top section of control cores $(P=0.004$, Table 5.4a). 


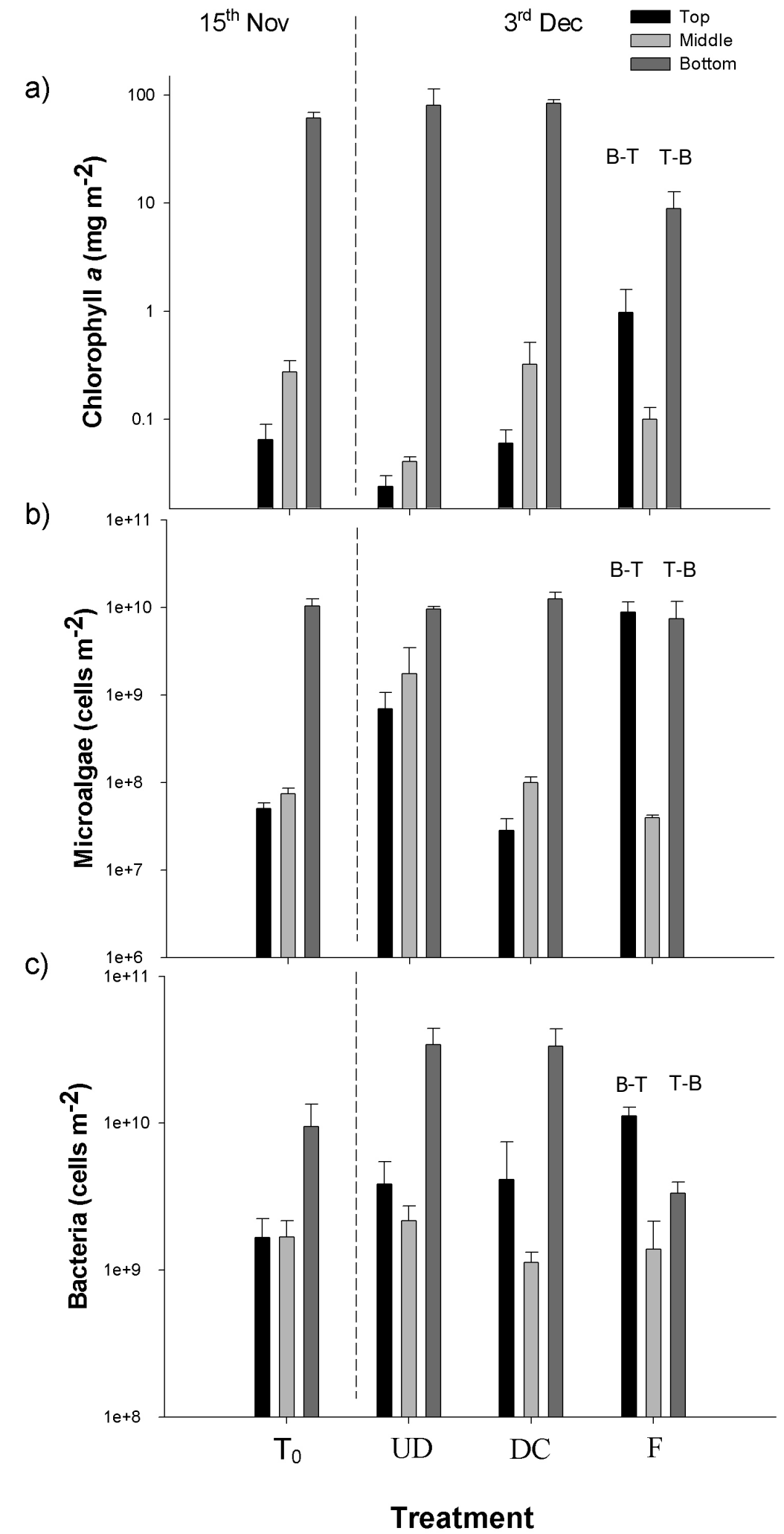

Figure 5.2: Concentration of chlorophyll $a$ (a), and abundance of microalgae (b), and bacteria (c) in the top (0-0.1 m), middle (1.25-1.35 m), and bottom $(2.5-2.6 \mathrm{~m})$ section of ice cores extracted on two occasions $\left(15^{\text {th }}\right.$ November, $3^{\text {rd }}$ December 2006) from annual fast-ice in Terra Nova Bay, Antarctica $(n=3)$. Treatments: Time zero $\left(\mathrm{T}_{0}\right)$, undisturbed control (UC), disturbed control (DC) and flipped (F; $\mathrm{B}-\mathrm{T}=$ bottom to top, $\mathrm{T}-\mathrm{B}=$ top to bottom). 
Table 5.1: One-way analysis of variance (ANOVA) and post hoc Tukey tests comparing ice core sections (top: T, middle: M, bottom: B) among four treatments (time zero: $\mathrm{T}_{0}$, undisturbed control: $\mathrm{UC}$, disturbed control: $\mathrm{DC}$, flipped: $\mathrm{F}$ ). The top section of the flipped cores is compared to the bottom sections of the control treatments $\left(\mathrm{FT}+\mathrm{T}_{0} \mathrm{~B}+\mathrm{UCB}+\mathrm{DCB}\right)$, the bottom of the flipped cores is compared to the top of the control treatments $\left(\mathrm{FB}+\mathrm{T}_{0} \mathrm{~T}+\mathrm{UCT}+\mathrm{DCT}\right)$, and mid core sections are compared among all treatments

$(\mathrm{FM}+\mathrm{T} 0 \mathrm{M}+\mathrm{UCM}+\mathrm{DCM})$. Variables examined are $\mathrm{Chl} a$ (chlorophyll $\left.a, \mathrm{mg} \mathrm{m}^{-2}\right)$, microalgae $\left(\right.$ cells $\left.\mathrm{m}^{-2}\right)$ and bacteria $\left(\right.$ cells $\left.\mathrm{m}^{-2}\right)$.

\begin{tabular}{|c|c|c|c|c|c|c|c|c|c|}
\hline \multirow{3}{*}{ Test } & \multicolumn{9}{|c|}{ ANOVA } \\
\hline & \multicolumn{3}{|c|}{ Chl $a$} & \multicolumn{3}{|c|}{ Microalgae } & \multicolumn{3}{|c|}{ Bacteria } \\
\hline & $F_{\mathrm{df}}$ & $P$ & Tukey & $\boldsymbol{F}_{\mathrm{df}}$ & $P$ & Tukey & $\boldsymbol{F}_{\mathrm{df}}$ & $P$ & Tukey \\
\hline $\mathrm{FT}+\mathrm{T}_{0} \mathrm{~B}+\mathrm{UCB}+\mathrm{DCB}$ & $68.527_{3}$ & $<0.01$ & $\begin{array}{l}\text { FT vs } \mathrm{T}_{0} \mathrm{~B}<0.01 \\
\text { FT vs } \mathrm{CB}<0.01 \\
\text { FT vs } \mathrm{DCB}<0.01\end{array}$ & $0.51_{3}$ & 0.69 & NA & $4.81_{3}$ & 0.03 & $\begin{array}{l}\mathrm{T}_{0} \mathrm{~B} \text { vs } \mathrm{CB}=0.07 \\
\mathrm{~T}_{0} \mathrm{~B} \text { vs } \mathrm{DCB}=0.06\end{array}$ \\
\hline $\mathrm{FB}+\mathrm{T}_{0} \mathrm{~T}+\mathrm{UCT}+\mathrm{DCT}$ & $27.724_{3}$ & $<0.01$ & $\begin{array}{l}\mathrm{FB} v s \mathrm{~T}_{0} \mathrm{~T}<0.01 \\
\mathrm{FB} v s \mathrm{CT}<0.01 \\
\mathrm{FB} v s \mathrm{DCT}<0.01\end{array}$ & $8.33_{3}$ & 0.02 & $\begin{array}{l}\mathrm{FB} v s \mathrm{DCT}=0.02 \\
\mathrm{FB} v s \mathrm{~T}_{0} \mathrm{~T}=0.04\end{array}$ & $0.34_{3}$ & 0.8 & NA \\
\hline $\mathrm{FM}+\mathrm{T}_{0} \mathrm{M}+\mathrm{UCM}+\mathrm{DCM}$ & $4.537_{3}$ & 0.06 & NA & $1.09_{3}$ & 0.41 & NA & $0.79_{3}$ & 0.53 & NA \\
\hline
\end{tabular}


a)

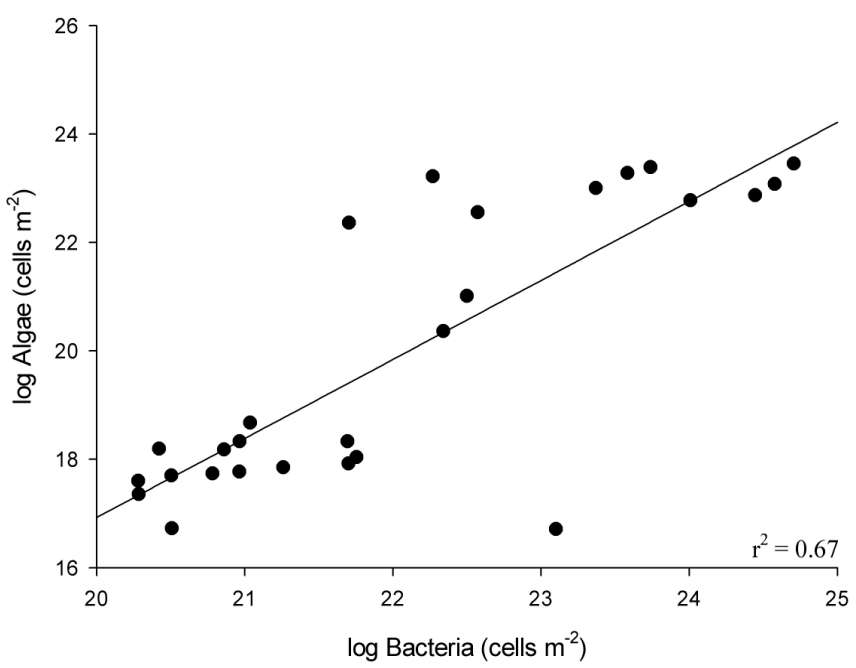

b)

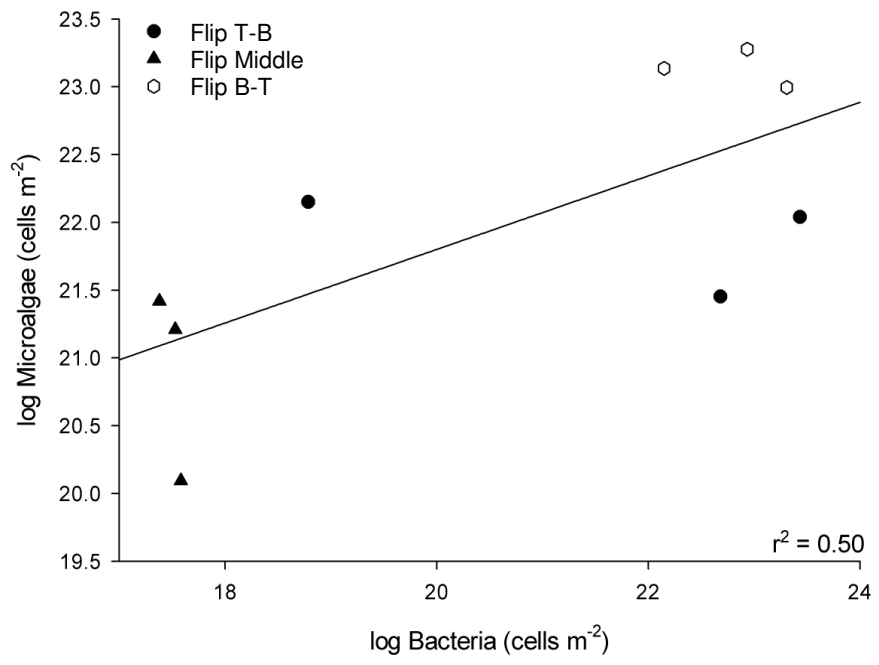

Figure 5.3: Correlation between the $\log$ abundance $\left(\right.$ cells $\left.\mathrm{m}^{-2}\right)$ of bacteria and microalgae in the top $(0-0.1 \mathrm{~m})$, middle $(1.25-1.35 \mathrm{~m})$ and bottom $(2.5-2.6 \mathrm{~m})$ sections of ice cores extracted from annual fast-ice in Terra Nova Bay. a) combined control treatments ( $\mathrm{T}_{0}$, undisturbed and disturbed); $\mathrm{b}$ ) flipped cores (T-B $=$ top to bottom, B-T = bottom to top). 
Table 5.2: PERMANOVA partitioning for the two-way experimental design, including contrasts explicitly to investigate the potential effects of flipping ice cores, for a) microalgal assemblages based on Bray-Curtis dissimilarities calculated from square-root-transformed standardised abundances and b) bacterial assemblages based in Dice similarity. $P$-values were obtained using 9,999 permutations of the raw data for both analyses. Time zero (T0), undisturbed control (UC), disturbed control (DC) and flipped (F) refer to experimental treatments; core sections (top, middle and bottom) are abbreviated by Se.

a)

\begin{tabular}{|c|c|c|c|c|c|}
\hline Source & $d f$ & $S S$ & $M S$ & Pseudo-F & $\boldsymbol{P}$ \\
\hline Treatment $(\mathrm{Tr})$ & 3 & 4631 & 1544 & 2.78 & 0.003 \\
\hline $\mathrm{F}-v s-\left\{\mathrm{DC}, \mathrm{UC}, \mathrm{T}_{0}\right\}$ & 1 & 2484 & 2484 & 4.26 & 0.005 \\
\hline $\mathrm{DC}-v s-\left\{\mathrm{UC}, \mathrm{T}_{0}\right\}$ & 1 & 578 & 578 & 0.83 & 0.522 \\
\hline $\mathrm{UC}-v s-\mathrm{T}_{0}$ & 1 & 1569 & 1569 & 1.94 & 0.099 \\
\hline Section (Se) & 2 & 3160 & 1580 & 2.85 & 0.009 \\
\hline $\mathrm{Tr} \times \mathrm{Se}$ & 6 & 4593 & 766 & 1.38 & 0.121 \\
\hline $\mathrm{F}-v s-\left\{\mathrm{DC}, \mathrm{UC}, \mathrm{T}_{0}\right\} \times \mathrm{Se}$ & 2 & 2566 & 1283 & 2.20 & 0.029 \\
\hline $\mathrm{DC}-v s-\left\{\mathrm{UC}, \mathrm{T}_{0}\right\} \times \mathrm{Se}$ & 2 & 632 & 316 & 0.45 & 0.943 \\
\hline $\mathrm{UC}-v s-\mathrm{T}_{0} \times \mathrm{Se}$ & 2 & 1395 & 698 & 0.86 & 0.526 \\
\hline Residual & 24 & 13317 & 555 & & \\
\hline Total & 35 & 25701 & & & \\
\hline
\end{tabular}

b)

\begin{tabular}{lcrrcr}
\hline Source & $\boldsymbol{d} \boldsymbol{f}$ & $\boldsymbol{S S}$ & $\boldsymbol{M S}$ & Pseudo-F & \multicolumn{1}{c}{$\boldsymbol{P}$} \\
\hline Treatment $(\mathrm{Tr})$ & 2 & 22688 & 11344 & 8.67 & $<0.001$ \\
F- $v s-\left\{\mathrm{DC}, \mathrm{UC}, \mathrm{T}_{0}\right\}$ & 1 & 13261 & 13261 & 7.52 & $<0.001$ \\
DC- $v s-\left\{\mathrm{UC}, \mathrm{T}_{0}\right\}$ & 1 & 9427 & 9427 & 7.22 & 0.002 \\
UC- $v s-\mathrm{T}_{0}$ & 2 & 14492 & 7246 & 5.54 & 0.000 \\
Section $(\mathrm{Se})$ & 4 & 17245 & 4311 & 3.29 & 0.002 \\
Tr $\times$ Se & 2 & 13209 & 6605 & 3.75 & 0.003 \\
F- $v s-\left\{\mathrm{DC}, \mathrm{UC}, \mathrm{T}_{0}\right\} \times \mathrm{Se}$ & 2 & 4036 & 2018 & 1.55 & 0.191 \\
DC- $v s-\left\{\mathrm{UC}, \mathrm{T}_{0}\right\} \times \mathrm{Se}$ & 18 & 23562 & 1309 & 8.67 & $<0.001$ \\
$\quad \mathrm{UC}-v s-\mathrm{T}_{0} \times \mathrm{Se}$ & 26 & 77988 & 11344 & 7.52 & $<0.001$ \\
Residual & 2 & 22688 & 13261 & & \\
Total & 1 & 13261 & & & \\
\hline
\end{tabular}


Algal communities from the middle section of flipped cores did not differ significantly from those located in either the top or middle sections of the control cores $(P>0.20$, Table 5.4a).

Analysis of the bacterial community data demonstrated a significant C-vs- $\mathrm{T}_{0} \times$ Section interaction term (PERMANOVA pseudo- $F_{2,24}=9.39, P<0.001$, Table 5.2b), indicating that differences among sections varied significantly through time. Data from cores in the $\mathrm{T}_{0}$ treatment were thus removed prior to analysis. Bacterial community structure among core sections was not affected by temporary core removal (i.e., D-vs-C $\times$ Section interaction term was not significant, $P>0.19$ ), but flipping had a significant effect $(\mathrm{F}-v s-\{\mathrm{D}, \mathrm{C}\} \times$ Section interaction term was significant, $P=0.003$, Table 5.2b). For the control treatments (UC and DC), the MDS plot showed bacterial assemblages from either the top or middle of the cores to the left of the diagram, while assemblages from the bottom occurred at the lower right (Figure 5.5). The bacterial community originally at the bottom of flipped cores (B-T) did not differ significantly from the bottom section of the control treatments $(P>0.13)$, and communities from the middle of flipped cores remained similar to those found in controls $(P>0.08$, Table 5.4b). However, the results for bacterial communities originally at the top (T-B) of the flipped cores were less clear; these communities were distinguishable from the top section of control treatments at the end of the experiment $(P=0.058$, Table 5.4b, Figure 5.5). 
Table 5.3: Microalgae and protozoa identified in this study. Values show the contribution (\%) to total biomass for core sections of interest. Haptophytes were not included in this analysis. Time zero (T0), disturbed control (DC) and flipped (F) refer to experimental treatments; bottom (B), middle (M), and top (T) refer to core sections.

Core Section

Taxon

TOB DCB FT

TOM DCM FM T0T DCT FB

\section{Autotrophs $>20$ um}

Berkeleya sp.

1.3

Chaetoceros sp.

$<1.0$

Chlorophyte sp. 1

Cylindrotheca sp. (str.)

Entomoneis sp. 1

Entomoneis sp. 2

Eucampia Antarctica

Fragilariopsis curta

Fragilariopsis cylindrus

Fragilariopsis rhombica

Fragilariopsis sp. 1

Fragilariopsis sp. 2

Fragilariopsis sublinearis

Haptophyte

Navicula sp. 1

Nitzschia lecointei

Nitzschia sp. 1

Nitzschia sp. 2

Nitzschia stellata

Pinnularia sp.

Pleurosigma sp.

Pseudo-nitzschia sp.

Centric diatom

$\begin{array}{rrr}23.9 & 20.7 & 21.6 \\ & <1.0 & <1.0 \\ & & \\ 11.7 & 20 & 10.4 \\ 5.4 & 5.8 & 5.1 \\ <1.0 & 1.1 & \\ 1.6 & 1.9 & 3.1 \\ 0.1 & 0.2 & \\ & <1.0 & <1.0 \\ & & \\ 30.7 & 30.5 & 43 \\ 1.2 & 1.6 & 1.1 \\ <1.0 & 1.2 & <1.0 \\ <1.0 & & <1.0 \\ 7.1 & 3.4 & \\ <1.0 & <1.0 & <1.0 \\ <1.0 & <1.0 & <1.0 \\ 1.5 & 1.5 & <1.0 \\ 1.1 & 1.1 & 1.2\end{array}$

$<1.0$

$\begin{array}{lll}16.3 & 17 & 10.9\end{array}$

7.2

$4.3 \quad 18.8 \quad 11.3$

$<1.0$

$<1.0$

$\begin{array}{lll}16.1 & 20.8 & 31.9\end{array}$

$\begin{array}{lll}27 & 15.7 & 22.2\end{array}$

$\begin{array}{lll}11.3 & 4.4 & 8.8\end{array}$

$\begin{array}{lll}26.6 & 14.2 & 8.2\end{array}$

$<1.0 \quad 5.6 \quad 5.4$

$3.3 \quad 10.7$

Heterotrohps $>20$ um

Ciliate sp. 1

$$
<1.0
$$

$<1.0$

Dinoflagellate cyst

$$
\begin{array}{rrr}
<1.0 & <1.0 & \\
1 & 1.7 & <1.0 \\
& & <1.0 \\
& & <1.0
\end{array}
$$

$5.1 \quad 1$


Microalgal communities

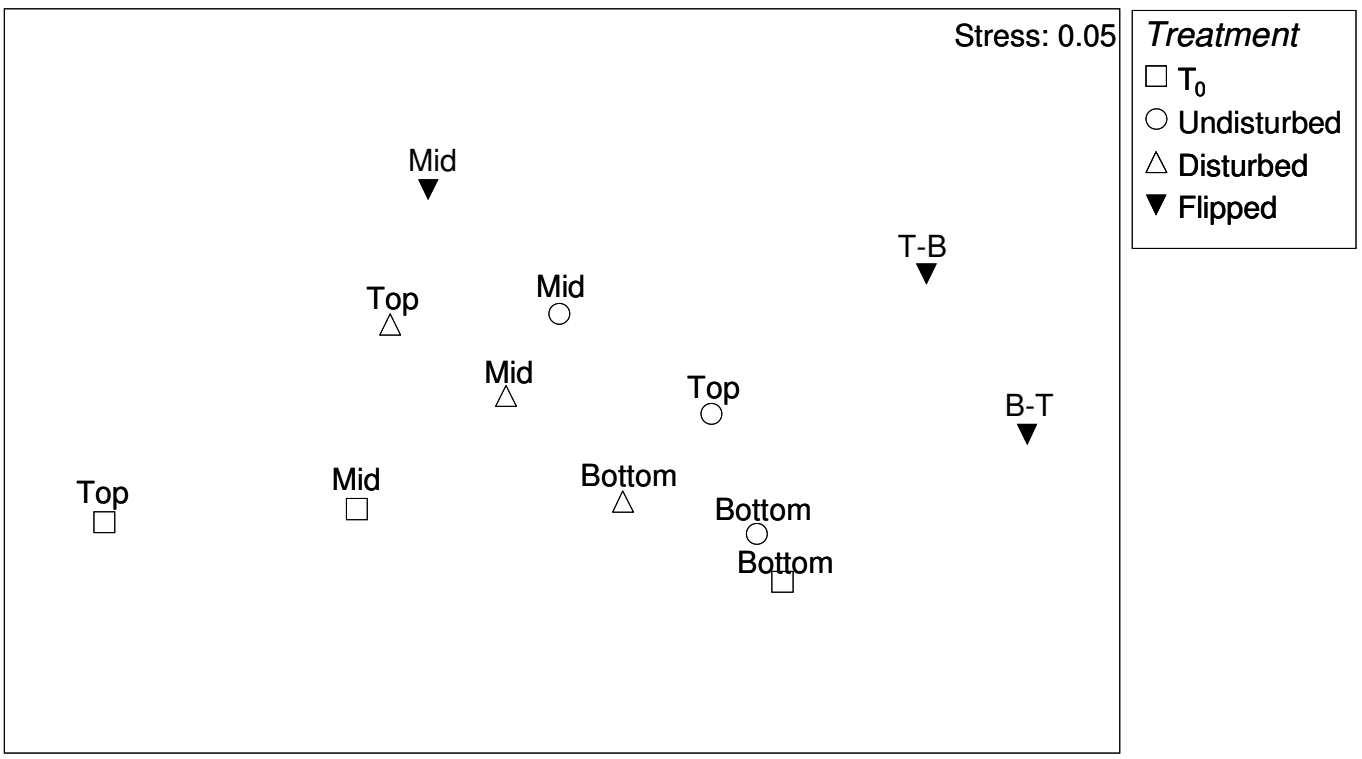

Figure 5.4: MDS plot of centroids $(n=3)$ for the twelve combinations of Treatment $\times$ Section, based on the Bray-Curtis dissimilarity matrix among sample units calculated from square-root transformed standardised abundances of algal community data (30 variables). $\mathrm{T}-\mathrm{B}=$ top to bottom, $\mathrm{B}-\mathrm{T}=$ bottom to top.

Bacterial phylotypes

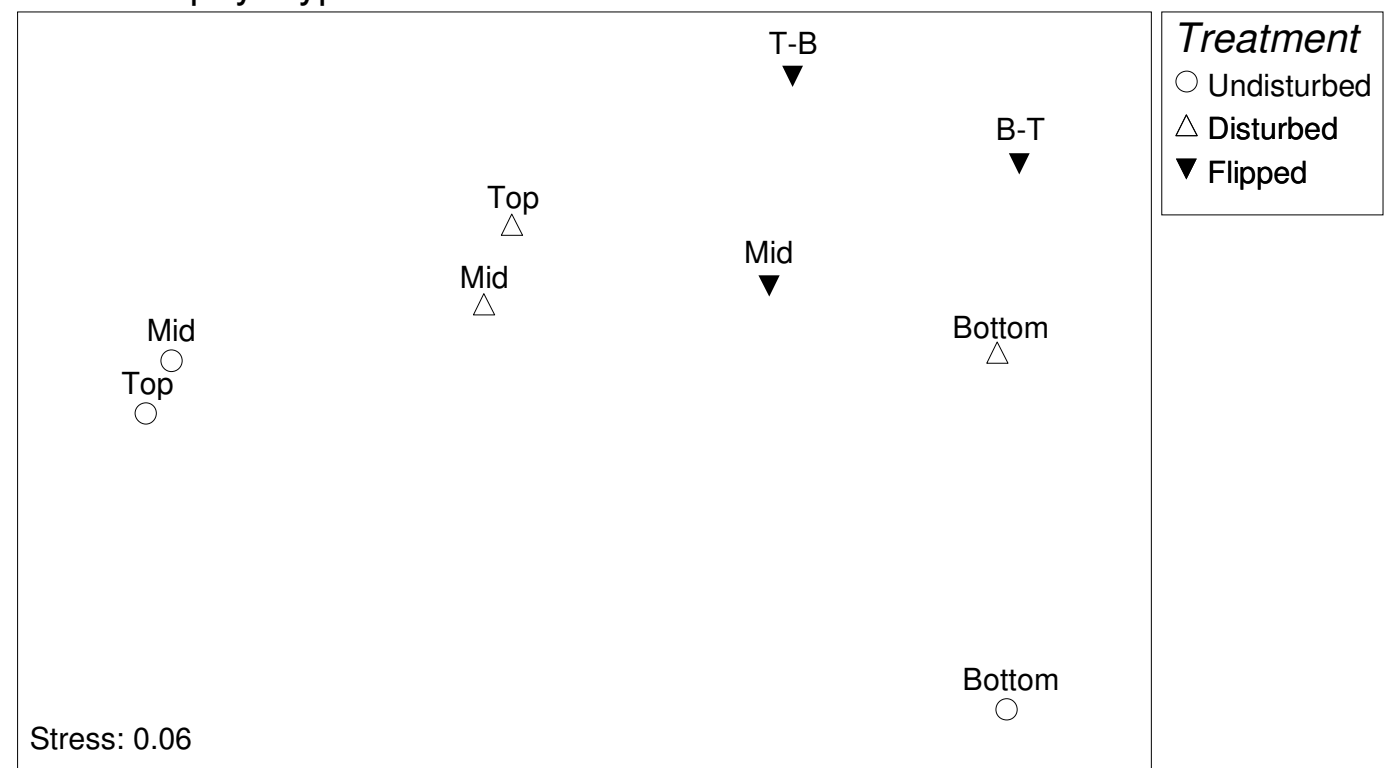

Figure 5.5: MDS plot of centroids $(n=3)$ for the 9 combinations of Treatment $\times$ Section (time zero cores omitted, see text for details), based on the Dice (Sørensen) similarity matrix among sample units calculated from DGGE band patterns of bacterial phylotypes. T-B $=$ top to bottom, B-T = bottom to top. 
Differences in the overall diversity and abundance measures for different sections of the cores differed for the flipped treatments compared to the controls (F-vs- $\{\mathrm{DC}, \mathrm{UC}$, $\left.\mathrm{T}_{0}\right\} \times$ Section, pseudo- $\left.F_{2,24}=5.29, P=0.001\right)$, and this was not confounded by either temporary core removal (DC- $v s-\left\{\mathrm{UC}, \mathrm{T}_{0}\right\} \times$ Section, pseudo- $F_{2,24}=0.92, P>$ $0.4)$ or variation through time (UC- $v s-\mathrm{T}_{0} \times$ Section, pseudo- $\left.F_{2,24}=0.76, P>0.5\right)$. Excluding the cores from the flipped treatment, the first two principal components accounted for $83.9 \%$ of the total variation. The communities from the bottom section of ice cores were clearly distinguishable (towards the left in the PCA plot) from those in either the middle or top sections, and were also less variable (Figure 5.6a).

In contrast, the diversity and abundance of communities from either the top or middle sections were not clearly distinguishable from one another. Bottom-ice communities were characterised by having higher abundance, high bacterial and algal diversity and also showed greater evenness (less dominance). When the communities from the flipped cores were included in the PCA (Figure 5.6b), those that were originally from either the top or bottom of the core occurred in the middle of the plot, apparently in transition between the two existing states (Table 5.4c). The diversity and productivity of communities from the middle of the flipped cores did not differ significantly from those in either the top or middle section of the control cores (Figure 5.6b, Table 5.4c). The average for each abundance and diversity measure in each section (top, middle and bottom) of the control treatments is shown in Table 5.5. 
Table 5.4: $P$-values for relevant pair-wise tests following a significant contrast in PERMANOVA to investigate interactions in the effects of flipping with differences among different sections of the ice cores for a) microalgae/protozoa community structure (based on Bray-Curtis dissimilarities) b) bacterial community composition (based on Dice similarities) and c) diversity and abundance measures (based on normalised Euclidean distances). All tests were performed using 9,999 permutations of the raw data and are exact, but note that no corrections for multiple tests have been applied. Time zero $\left(\mathrm{T}_{0}\right)$, undisturbed control (UC), disturbed control (DC) and flipped refer to experimental treatments. Top, middle and bottom refer to core sections (Se).

a) Algal communities (following a significant F- $v s-\{\mathrm{DC}, \mathrm{UC}, \mathrm{T} 0\} \times \mathrm{Se}$ interaction, see Table 5.2)

\begin{tabular}{|l|l|ccc|}
\hline \multicolumn{1}{|c}{} & \multicolumn{4}{c|}{ Flipped } \\
\cline { 2 - 5 } Others & & Top & Middle & Bottom \\
\cline { 2 - 5 }$\{$ DC,UC,T0 $\}$ & Top & 0.023 & 0.227 & 0.059 \\
& Middle & 0.016 & 0.478 & 0.020 \\
& Bottom & 0.004 & 0.004 & 0.004 \\
\hline
\end{tabular}

b) Bacterial composition (following a significant F- $v s-\{D C, U C\} \times \mathrm{Se}$ interaction; T0 was omitted, see text for details)

\begin{tabular}{|l|l|ccc|}
\hline \multicolumn{1}{|c}{} & \multicolumn{4}{c|}{ Flipped } \\
\cline { 2 - 5 } Others & & Top & Middle & Bottom \\
\cline { 2 - 5 }$\{$ DC,UC $\}$ & Top & 0.011 & 0.060 & 0.058 \\
& Middle & 0.025 & 0.088 & 0.035 \\
& Bottom & 0.132 & 0.062 & 0.083 \\
\hline
\end{tabular}

c) Diversity and abundance measures (following a significant F- $v s$ $\{\mathrm{DC}, \mathrm{UC}, \mathrm{T} 0\} \times \mathrm{Se}$ interaction, see text for details)

\begin{tabular}{|l|l|ccc|}
\hline \multicolumn{1}{l|}{} & \multicolumn{4}{c|}{ Flipped } \\
\cline { 2 - 5 } Others & & Top & Middle & Bottom \\
\cline { 2 - 5 }$\{$ DC,UC,T0 $\}$ & Top & 0.010 & 0.554 & 0.010 \\
& Middle & 0.008 & 0.214 & 0.009 \\
& Bottom & 0.004 & 0.004 & 0.004 \\
\hline
\end{tabular}


Heterogeneity in the composition of the algal communities ( $\beta$-diversity) correlated well with these observed differences in environmental variation (Figure 5.1) Significantly greater $\beta$-diversity (i.e. the dispersion of points in the multivariate space based on presence-absence data) was observed for microalgal assemblages in either the top or in the middle core sections, compared to those at the bottom (PERMDISP $F_{2,24}=9.34, P=0.001$, Figure 5.7a, Table 5.5). Significantly greater $\beta$-diversity at the top and middle of ice cores was also apparent for bacterial assemblages (PERMDISP $F_{2,24}=3.43, P=0.038$, Table 5.5), although visually the pattern was not as strong (Figure 5.7b).

Table 5.5: Summary of average values for measures of productivity, diversity, evenness for each of the top, middle and bottom sections from unflipped cores. Measures of $\beta$-diversity were calculated as the average within-group DiceSørensen dissimilarity.

\begin{tabular}{|llcrr|}
\hline & & Top & Middle & Bottom \\
\hline Microalgae & Richness (no. of taxa, or $\alpha$-diversity) & 11.22 & 13.11 & 15.11 \\
& $\begin{array}{l}\text { Heterogeneity in composition }(\beta- \\
\text { diversity) }\end{array}$ & 30.39 & 35.28 & 19.97 \\
& Simpson's evenness $\left(1-\lambda{ }^{\prime}\right)$ & 0.569 & 0.632 & 0.784 \\
Bacteria & $\begin{array}{l}\text { Richness (no. of taxa, or } \alpha \text {-diversity) } \\
\text { Heterogeneity in composition }(\beta-\end{array}$ & 17.67 & 16.56 & 24.11 \\
& $\begin{array}{l}\text { diversity) } \\
\text { dive }\end{array}$ & 69.55 & 67.55 & 56.16 \\
\hline
\end{tabular}


a) without flipped treatments

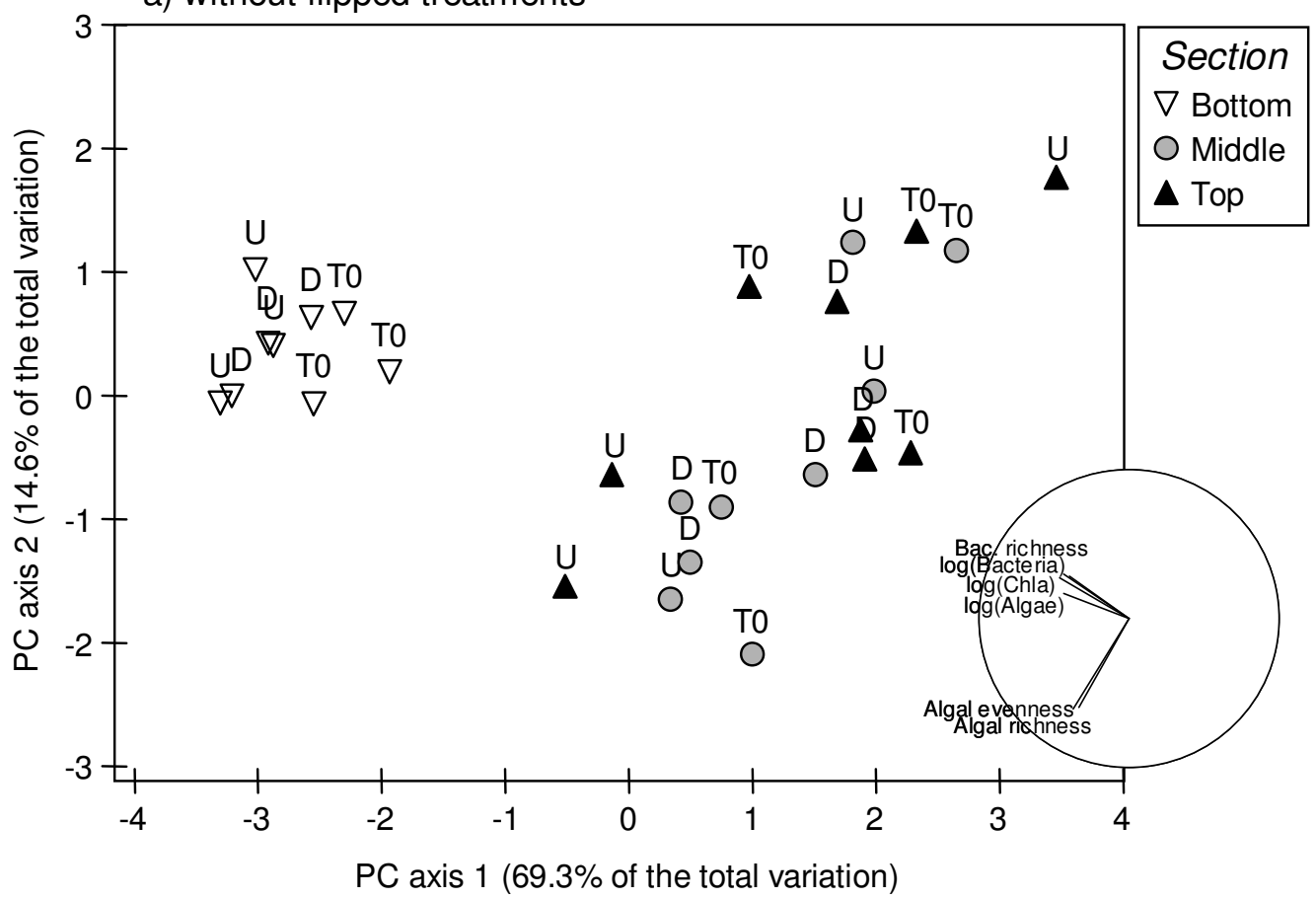

b) including flipped treatments

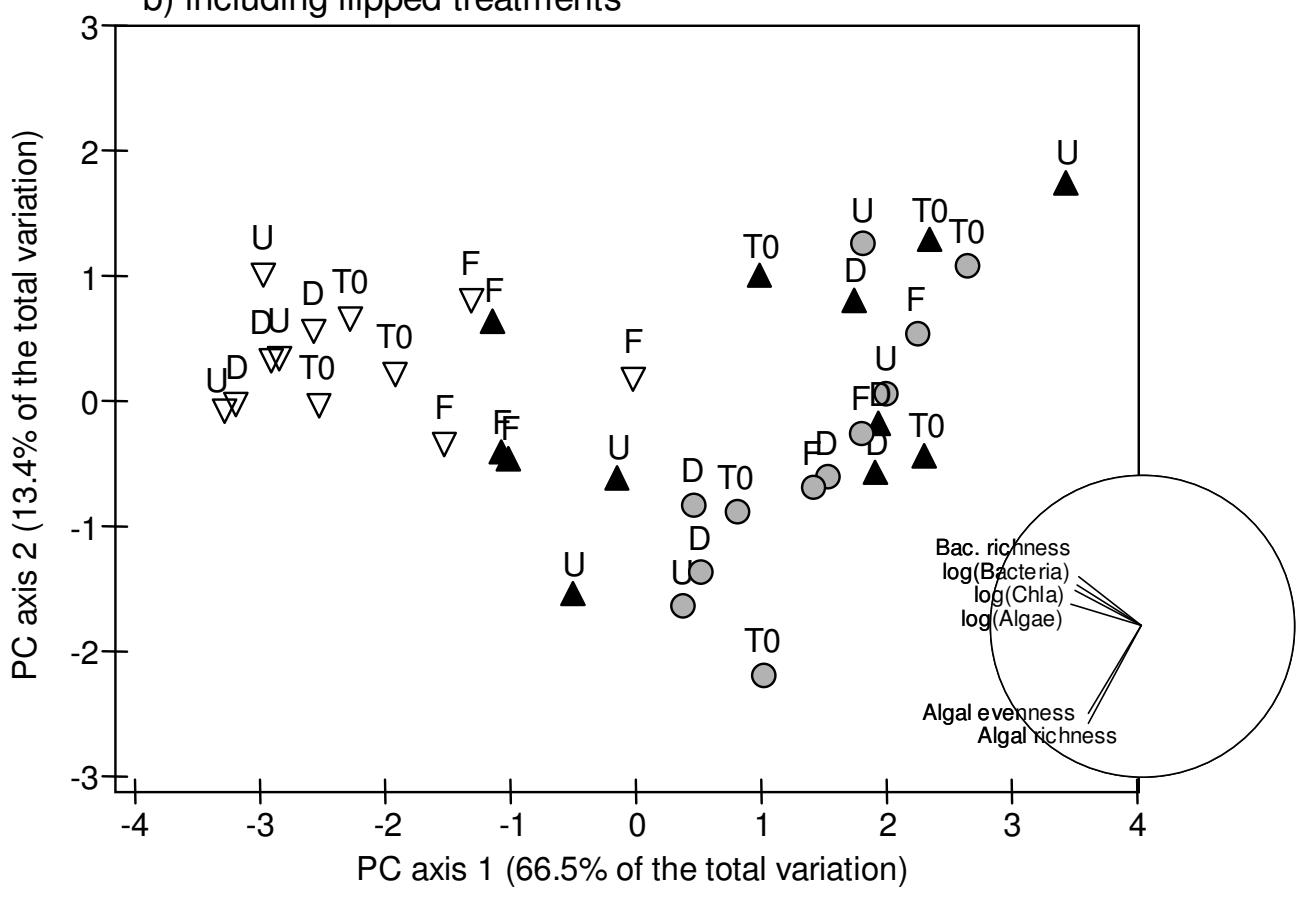

Figure 5.6: PCA of six algal and bacterial diversity and abundance measures a) without the cores from the flipped treatment and $b$ ) including the cores from the flipped treatment. In each case, eigenvectors showing the direction and relative importance of individual variables in constructing the PC axes are shown as vectors relative to the unit circle at lower right. 
a) Microalgal community composition

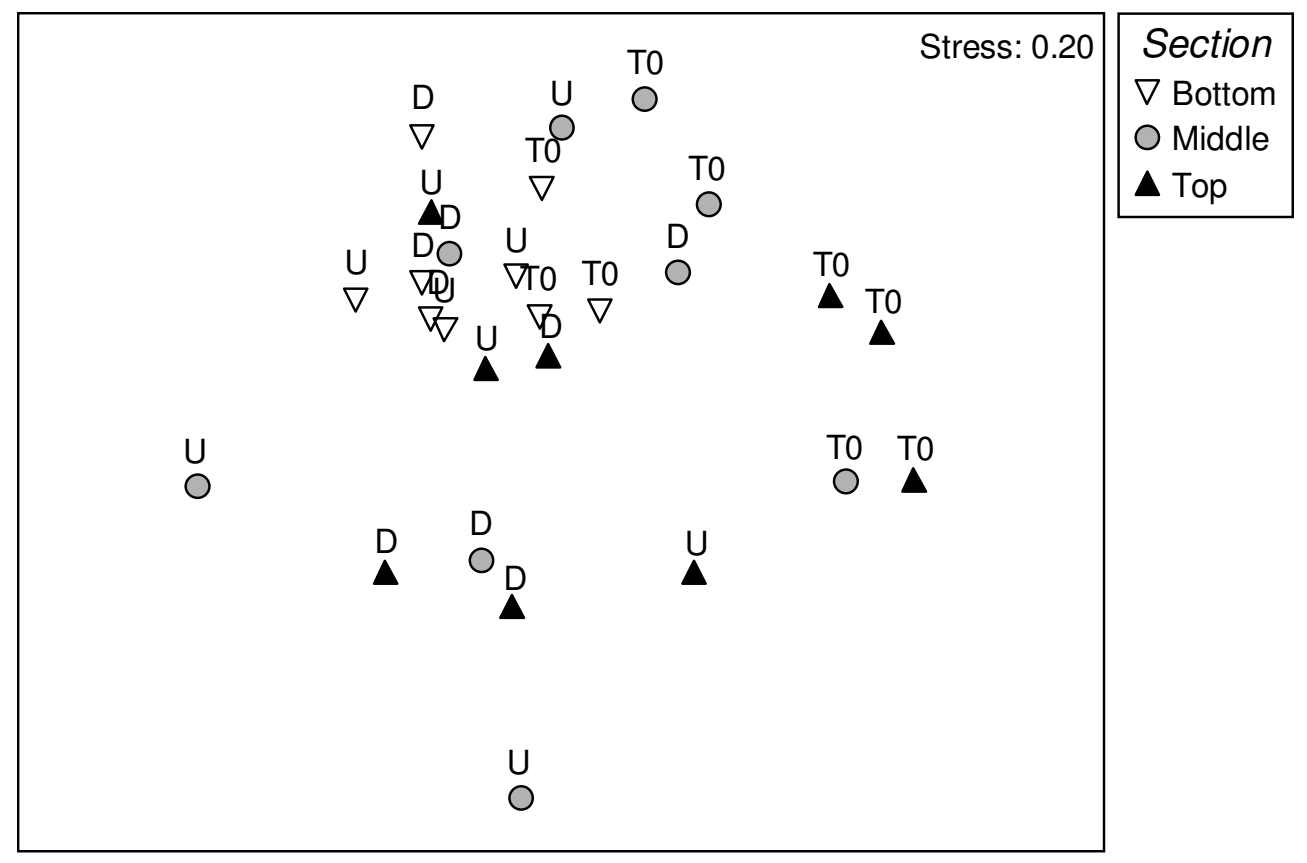

b) Bacterial community composition

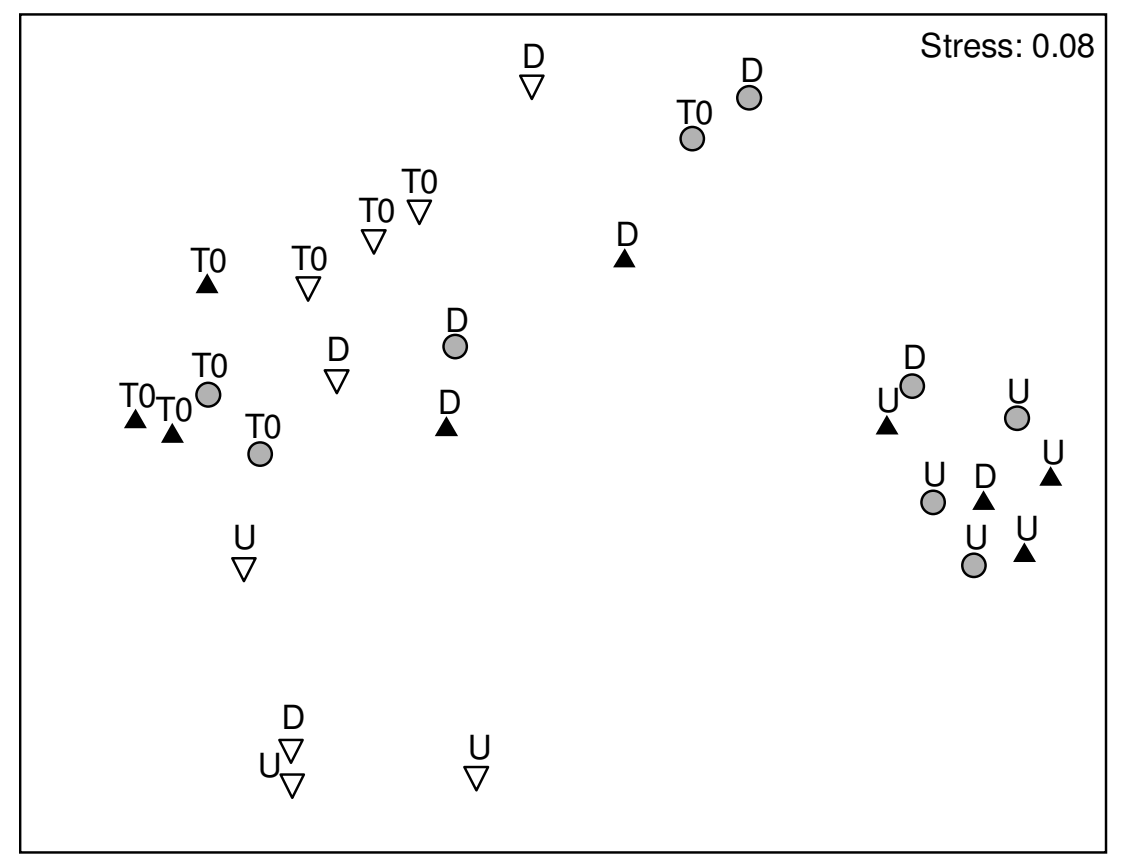

Figure 5.7: MDS plot of a) algal communities and b) bacterial communities based on the Dice (Sørensen) similarity measure among sample units (emphasising compositional differences in the identities of taxa or phylotypes), excluding the flipped treatment. 
Among the bacterial phylotypes that were visualised using DGGE, 14 were

successfully excised, re-run on a second gel to confirm migration location and

subsequently sequenced. Thirteen bands were affiliated with either the $\alpha$ or $\gamma$

subdivision of the Proteobacteria, while one band was affiliated with the Firmicutes

(Figure 5.8, Figure 5.9, Table 5.6).

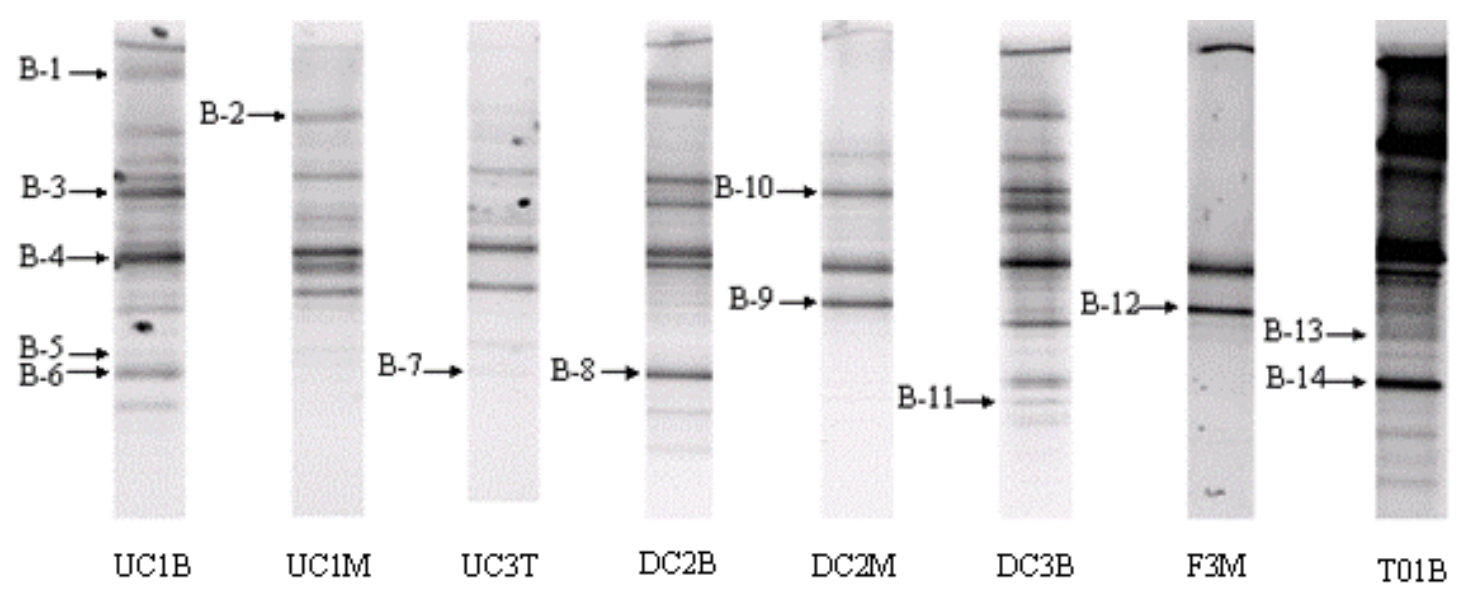

Figure 5.8: DGGE bands selected for excision and sequencing (B-1 to B-14).

Undisturbed control (UC), disturbed control (DC), flipped (F) and time zero $\left(\mathrm{T}_{0}\right)$ refer to experimental treatments; numbers 1-3 refer to core replicates; bottom (B), middle $(\mathrm{M})$, and top $(\mathrm{T})$ refer to core sections.

\subsection{Discussion}

The relationship between community composition and ecosystem function has generally been ignored in the field of microbial ecology (Reed \& Martiny 2007), however it is becoming increasingly urgent to anticipate the consequences of the loss of annual ice predicted for the Antarctic coastal ecosystem (17-31\%) within the next century (Rind et al. 1997, Meehl et al. 2000, Arrigo \& Thomas 2004). With the exception of Junge and co-workers (2001) who developed a method with 


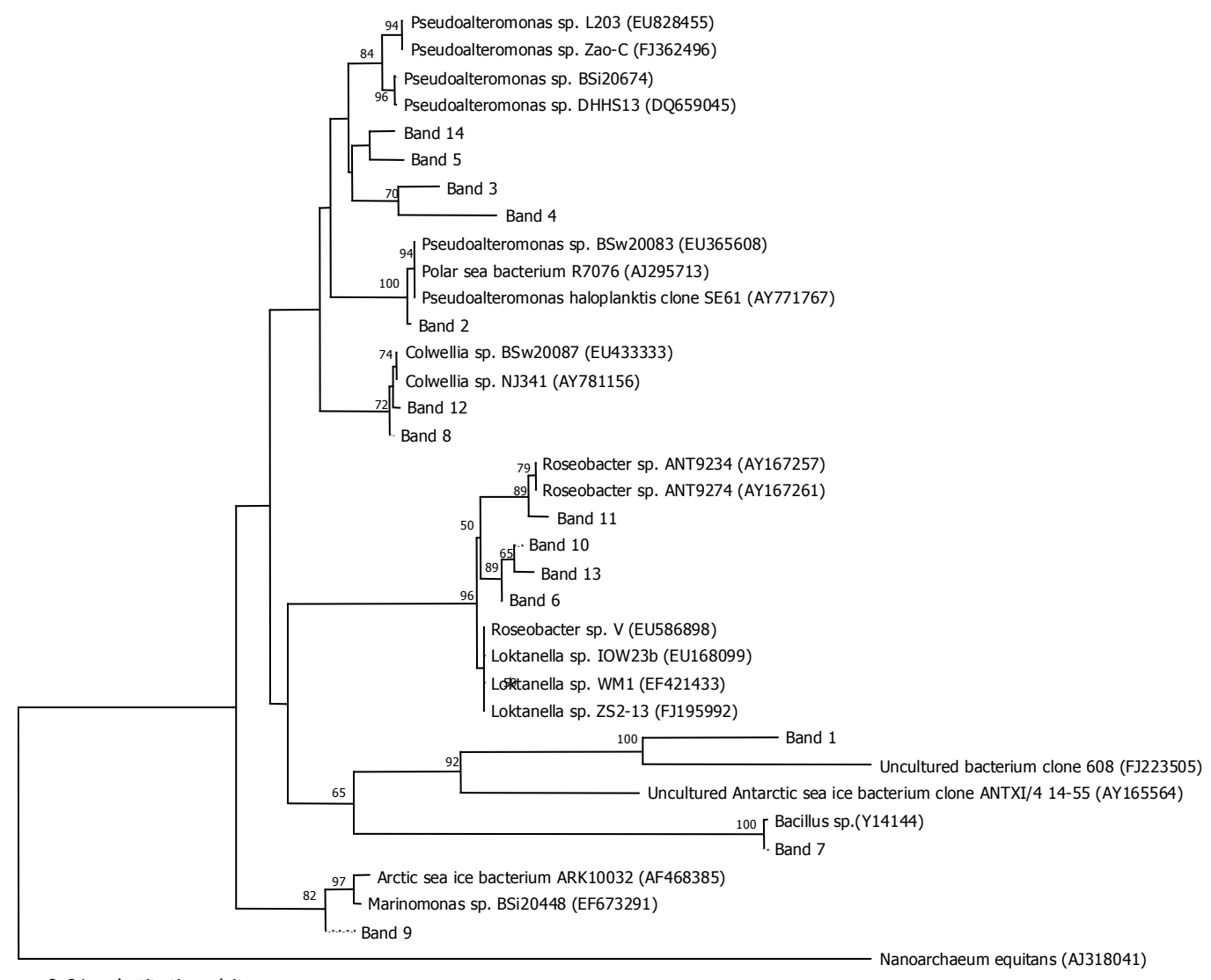

-0.01 substitutions/site

Figure 5.9: Neighbour-joining tree showing the relationship of $16 \mathrm{~S}$ ribosomal DNA sequences of excised DGGE bands (160 bp) from annual fast-ice at Terra Nova Bay, Antarctica, together with nearest neighbours from the $\alpha$ and $\gamma$ subdivisions of the Proteobacteria and Firmicutes. Band 1 to Band $14=$ excised bands displayed in Figure 5.8. The accession numbers of the reference sequences used in the calculation are reported in parentheses. Maximum-likelihood bootstrap resampling values greater than 50\% (10,000 replicates) are indicated near the nodes. The $16 \mathrm{~S}$ rRNA gene sequence of Nanoarcheaum equitans was used as the outgroup. The scale bar represents $1 \%$ estimated sequence divergence. 
Table 5.6: Phylogenetic affiliation of sequences obtained from denaturing gradient gel electrophoresis (DGGE) bands with closest matches from BLAST search of the GenBank database. B-1 to B-14 = excised bands displayed in Figure 5.8. Sequence similarity was calculated from 160 base pairs.

\begin{tabular}{|c|c|c|c|c|c|}
\hline Band & $\begin{array}{c}\text { Closest match } \\
\text { (environmental or culture) }\end{array}$ & $\begin{array}{c}\text { Sequence } \\
\text { similarity }(\%)\end{array}$ & $\begin{array}{c}\text { Taxonomic } \\
\text { Group }\end{array}$ & Source & $\begin{array}{c}\text { GenBank } \\
\text { accession } \\
\text { number }\end{array}$ \\
\hline B-1 & Uncultured bacterium clone 608 & 83.3 & Environmental & Antarctic seawater & FJ223505 \\
\hline \multirow[t]{3}{*}{ B-2 } & Pseudoalteromonas sp. BSw20083 & 100 & $\begin{array}{l}\gamma \text {-Proteobacterial } \\
\text { Pseudoalteromonadaceae }\end{array}$ & Arctic seawater & EU365608 \\
\hline & Pseudoalteromonas haloplanktis clone SE61 & 100 & $\begin{array}{l}\gamma \text {-Proteobacterial } \\
\text { Pseudoalteromonadaceae }\end{array}$ & Arctic seawater & AY771767 \\
\hline & Polar sea bacterium R7076 & 100 & Environmental & Polar seawater & AJ295713 \\
\hline B-3 & Pseudoalteromonas sp. BSi20674 & 93.2 & $\begin{array}{l}\gamma \text {-Proteobacterial } \\
\text { Pseudoalteromonadaceae }\end{array}$ & Arctic sea- ice & DQ517881 \\
\hline B-4 & Pseudoalteromonas sp. BSi20674 & 91.2 & $\begin{array}{l}\gamma \text {-Proteobacterial } \\
\text { Pseudoalteromonadaceae }\end{array}$ & Arctic sea-ice & DQ517881 \\
\hline \multirow[t]{2}{*}{ B-5 } & Pseudoalteromonas sp. Zao-C & 97 & $\begin{array}{l}\gamma \text {-Proteobacterial } \\
\text { Pseudoalteromonadaceae }\end{array}$ & Polar & FJ362496 \\
\hline & Pseudoalteromonas sp. L203 & 97 & $\begin{array}{l}\gamma \text {-Proteobacterial } \\
\text { Pseudoalteromonadaceae }\end{array}$ & Antarctica & EU828455 \\
\hline B-6 & Loktanella sp. ZS2-13 & 100 & $\begin{array}{l}\gamma \text {-Proteobacterial } \\
\text { Rhodobacteraceae }\end{array}$ & Antarctic marine sediments & FJ195992 \\
\hline B-7 & Bacillus sp. & 100 & $\begin{array}{l}\text { Firmicutes } \\
\text { Bacillaceae }\end{array}$ & Marine & Y14144 \\
\hline
\end{tabular}




\begin{tabular}{|c|c|c|c|c|c|}
\hline Band & $\begin{array}{c}\text { Closest match } \\
\text { (environmental or culture) }\end{array}$ & $\begin{array}{c}\text { Sequence } \\
\text { similarity }(\%) \\
\end{array}$ & $\begin{array}{c}\text { Taxonomic } \\
\text { Group } \\
\end{array}$ & Source & $\begin{array}{c}\text { GenBank } \\
\text { accession } \\
\text { number } \\
\end{array}$ \\
\hline \multirow[t]{2}{*}{ B-8 } & Colwellia sp. BSw20087 & 100 & $\begin{array}{l}\gamma \text {-Proteobacterial } \\
\text { Colwelliaceae }\end{array}$ & Arctic seawater & EU433333 \\
\hline & Colwellia sp. NJ341 & 100 & $\begin{array}{l}\gamma \text {-Proteobacterial } \\
\text { Colwelliaceae }\end{array}$ & Antarctic psychrophile & AY781156 \\
\hline B-9 & Marinomonas sp. BSi20448 & 100 & $\begin{array}{l}\gamma \text {-Proteobacterial } \\
\text { Oceanospirillales }\end{array}$ & Arctic sea-ice & EF673291 \\
\hline B-10 & Loktanella sp. ZS2-13 & 96.2 & $\begin{array}{l}\text { Proteobacteria } \\
\text { Rhodobacteraceae }\end{array}$ & Antarctic marine sediments & FJ195992 \\
\hline \multirow[t]{2}{*}{ B-11 } & Roseobacter sp. ANT9274 & 100 & $\begin{array}{l}\alpha \text {-Proteobacterial } \\
\text { Rhodobacteraceae }\end{array}$ & Sea- ice & AY167261 \\
\hline & Roseobacter sp. ANT9234 & 100 & $\begin{array}{l}\alpha \text {-Proteobacterial } \\
\text { Rhodobacteraceae }\end{array}$ & Sea- ice & AY167257 \\
\hline B-12 & Colwellia sp. BSw20087 & 100 & $\begin{array}{l}\gamma \text {-Proteobacterial } \\
\text { Colwelliaceae }\end{array}$ & Arctic seawater & EU433333 \\
\hline B-13 & Loktanella sp. ZS2-13 & 98.4 & $\begin{array}{l}\gamma \text {-Proteobacteria } \\
\text { Rhodobacteraceae }\end{array}$ & Antarctic marine sediments & FJ195992 \\
\hline B-14 & Pseudoalteromonas sp. BSi20674 & 95.6 & $\begin{array}{l}\gamma \text {-Proteobacterial } \\
\text { Pseudoalteromonadaceae }\end{array}$ & Arctic sea-ice & DQ517881 \\
\hline
\end{tabular}


which to visualise microbes present within thin sections of sea-ice and McMinn et al. (2000) who pioneered the deployment of oxygen electrodes to obtain under-ice estimates of microalgal productivity, experimental work has historically relied on melted ice cores or extracted brine. Although reciprocal transplant experiments are considered useful in simultaneously testing community composition and environmental variables on ecosystem structure and function (Reed \& Martiny 2007, Allison \& Martiny 2008), this methodology has not been applied in ecological studies of Antarctic sea-ice.

The vertical ice thickness at Terra Nova bay in 2006 was $2.6 \mathrm{~m}$, and although confirmed to be annual ice, this is atypical of fast-ice in coastal regions. Considerable care was thus taken in reinserting cores of this length (disturbed control and flipped treatments) back into the ice matrix. Within $24 \mathrm{~h}$ there was superficial evidence that each core had reintegrated into the surrounding ice, and this was confirmed when the cores were again extracted at the conclusion of the experiment. In general, the control treatments were useful in documenting the distribution and abundance of seaice microbes (Table 5.5, Figure 5.5a), illustrating change in the relative abundance of the sea-ice biota over $18 \mathrm{~d}\left(\mathrm{~T}_{0}\right.$, undisturbed control), and confirming that in situ assemblages were not significantly influenced by shearing of the ice or temporary core removal (disturbed control)(Figure 5.2, Table 5.1, Table 5.2).

Interestingly, there was no significant change in the abundance of microalgae or concentration of Chl $a$ after $18 \mathrm{~d}$ in either the top, middle or bottom sections of the control or disturbed control treatments. The high microalgal counts observed in the top of the undisturbed control treatment are accounted for by experimental error in 
post-melt sub-sampling. In contrast, the abundance of bacteria increased between $15^{\text {th }}$ November and $3^{\text {rd }}$ December in the top and bottom sections of the control and disturbed control treatments (Figure 5.2, Table 5.1, $P \sim 0.05$ ).

The collection of physical data from within the sea-ice is uncommon in ecological studies, primarily due to the logistical constraints of embedding and subsequently retrieving probes (Lazzara et al. 2007). PAR is often derived using radiative transfer models (Maykut \& Grenfell 1975), however I opted to collect direct measurements for greater accuracy. The successful deployment of light and temperature loggers enabled a reasonable characterisation of the physicochemical environment within the three regions of interest (Figure 5.1). For bottom-ice microbes that were exposed to the surface region of the ice profile (B-T), in situ light levels increased dramatically (18 d surface mean was $540 \mu \mathrm{mol}$ photons $\mathrm{m}^{-2} \mathrm{~s}^{-1}$ and $27 \mu \mathrm{mol}$ photons $\mathrm{m}^{-2} \mathrm{~s}^{-1}$ at 0.5 $\mathrm{m})$ and this was accompanied by an average drop in temperature of $4^{\circ} \mathrm{C}$ and a 3 -fold increase in salinity. In contrast, microbes acclimated to the surface and moved to the bottom of the ice (T-B) were subjected to warmer, less saline conditions that are typical of the water column $\left(-1.8^{\circ} \mathrm{C}, 36 \%\right.$ ), but the level of irradiance was reduced to $<1.6 \mu \mathrm{mol}$ photons $\mathrm{m}^{-2} \mathrm{~s}^{-1}$ due to high light attenuation.

The main limitation to photosynthesis and primary production in fast-ice bottom-ice communities is light attenuation from the overlying ice. In 1.5-1.8 m fast-ice with 5$10 \mathrm{~cm}$ of snow cover, attenuation is usually equivalent to a midday in situ irradiance of only 1-10 $\mu \mathrm{mol}$ photons $\mathrm{m}^{-2} \mathrm{~s}^{-1}$ (McMinn et al. 1999b). Microalgae in this region of the ice have photosynthetic mechanisms that saturate at low levels of irradiance and while the ability to photoacclimate to low light requires changes in both the 
concentration and composition of intracellular photosynthetic pigments, growth can be maintained at $0.3 \mu \mathrm{mol}$ photons $\mathrm{m}^{-2} \mathrm{~s}^{-1}$ (Palmisano \& Sullivan 1983, Thomas \& Dieckmann 2002). In general, optimal growth in ice-associated microalgae occurs at irradiances $<200 \mu \mathrm{mol}$ photons $\mathrm{m}^{-2} \mathrm{~s}^{-1}$, but if cells are subsequently exposed to high irradiances, this can cause photoinhibition or reduced photosynthetic efficiency (Ralph et al. 2007, Ryan et al. 2009, in press). While there is also thought to be an additional effect of low temperature and nutrient limitation, this has received limited attention in the literature (Mock \& Thomas 2005).

In the current study, the exposure of highly shade-adapted bottom-ice algae to conditions near the surface of the ice profile (B-T) is likely to have killed the cells closest to the ice surface, as evidenced by significant bleaching of photosynthetic pigments (reduction in $\mathrm{Chl} a$ )(Figure 5.2) and a shift in community composition and diversity (Table 5.2a, Figure 5.4, Figure 5.6b). Although there was zero net growth over $18 \mathrm{~d}$, the potential for a photoprotective response has been described by Griffith et al. (2009) and the survival of microalgae has recently been documented by Mangoni et al. (2009) who extracted ice cores at Terra Nova Bay and subsequently exposed the microalgae to $\sim 42 \mu \mathrm{mol}$ photons $\mathrm{m}^{-2} \mathrm{~s}^{-1}$ for a period of $12 \mathrm{~d}$. Given that Chl $a$ was still detected in the current study, it is probable that a proportion of the microalgae and protozoa survived this transition.

In contrast, the abundance of cells originally at the top of the ice profile increased significantly when exposed to the ice/water interface (T-B)(Figure 5.2). With the exception of Berkeleya sp. and several other newly aquired species that were present in low numbers, this increase appears to have been from cells pre-existing in the ice, 
rather than a new suite of species scavenged from the water column (Table 5.2a, Table 5.3). The potential for rapid growth in microalgae formally exposed to high irradiances may indicate that the lack of growth in bottom-ice microalgae exposed to the surface is due not only to increased irradiance, but also lowered temperature. Although originally in close proximity with the nutrient-rich water column, limitation of nitrate and iron (potentially enhanced by nutrients leaching down through the ice) may also have restricted the synthesis of proteins and pigments that are required for acclimation to high light (Mock \& Kroon 2002). In addition, the lower in situ ice temperature is likely to have exposed the microbial community to significantly increased saline concentrations, and this has recently been shown to exacerbate the photosynthetic stress response in microalgae incubated under high light (Ralph et al. 2007).

While a synergistic effect of increased irradiance, low temperature, and potential nutrient limitation on bottom-ice algae exposed to surface conditions can be inferred by the reciprocal response of the surface community, these data provide equal support for the hypothesis that the increased abundance in cells in the bottom of the flipped cores was from colonisation by microalgae from the surrounding ice (Table 5.3). Although taxonomic diversity increased over $18 \mathrm{~d}$ (Figure 5.6b) and the community composition differed with respect to the bottom sections of the control treatments (Table 5.2a), it is not possible to substantiate the origin of these new cells. The most likely explanation however pertains to the amount of light attenuated by $2.6 \mathrm{~m}$ sea-ice and rapid self-shading by microalgae. The congelation layer of annual fast-ice is generally characterised by an increase in microalgal biomass during the austral spring (Ryan et al. 2006), however low light and subsequent self-shading by 
pre-existing phototrophic cells accounts for the lack of growth in the bottom section of the control treatments. Conversely, the limited biomass initially present in the bottom of the flipped cores (T-B) would enable a period of rapid colonisation and growth from nearby cells.

Despite the application of both cultivation- and molecular-based studies, an understanding of the functional capabilities of bacteria in Antarctic sea-ice still remains fragmentary (Murray \& Grzymski 2007). Following the initial freeze, psychrophilic species are known to dominate bacterial populations, and although cells from both the bottom-ice and high-brine regions exhibit relatively high metabolic activity (Kottmeier et al. 1987, Martin et al. 2008, Martin et al. 2009, in review), the taxonomic diversity of sea-ice bacteria, either vertically within the ice or across geographical regions, has received remarkably little attention.

As with the microalgal community, the in situ distribution of sea-ice bacteria is likely to reflect species-specific environmental tolerances but also the availability of growth substrates. In comparison to the top and middle regions of the ice, the abundance of bacteria and number of distinct phylotypes generated with DGGE was significantly greater in the bottom section of the control cores (Figure 5.2, Table 5.5). This distribution highlights the physicochemical variability within the ice. Further, the lower heterogeneity ( $\beta$-diversity) of the bacterial assemblage at the ice/water interface illustrates the degree of stability in this region of the matrix, particularly with respect to DOM. However, the increase in bacteria observed in the control treatments, coupled with the distinct lack of growth in the cores that were flipped, suggests that the distribution and abundance of bacteria is limited not only by the 
availability of growth substrates, but also by low temperature. Thus, while the degradation of light-shocked microalgae may have increased the concentration of labile DOM growth substrate available to bacteria (B-T), I suggest that metabolism may have been temperature-limited. The effects of low temperature, high salinity, and high light are essentially confounded, but bottom-ice bacteria have been shown to exhibit a high tolerance to increased saline concentrations (Kottmeier \& Sullivan 1988, Martin et al. 2009) and the presence of light-sensitive bacteria (and potential photoinhibition) in sea-ice has yet to be confirmed.

Limited experimental work with sea-ice microbial communities has highlighted a rapid response of bacteria to algal-derived DOM (Giesenhagen et al. 1999, Martin et al. 2009, Martin et al. 2009, in review), but the extent to which this reflects in situ microbial loop dynamics is unknown. The positive correlation in the control treatments between microalgae and bacteria present in the top, middle and bottom sections of cores implies an active microbial loop at the time of sampling (Figure 5.3a). Minimal growth by microalgae between $15^{\text {th }}$ November and $3^{\text {rd }}$ December however, signals a plateau in the growth of the autotrophic component of the community, and this typically occurs in mid-late November in Terra Nova Bay (Lazzara et al. 2007). The continued increase of bacteria in the control treatments is most likely due to a lag in the response time of bacteria to the photosynthate made available during the development of the microalgal biomass (Archer et al. 1996, Garrison et al. 2005). Of equal importance to the microbial loop dynamic is the consumption of bacteria by protozoan grazers. Although a number of flagellates and ciliates were identified within the ice, a significant increase in the abundance of these grazers was not observed during the course of the experiment (data not shown). 
The delayed response of bacteria to the enhanced concentration of DOM at the bottom of the flipped cores has important implications for the interpretation of previous in vitro experiments. Martin et al (2009, in review) have recently cultured sea-ice microbes for a period of $9 \mathrm{~d}$ and found that both the growth rate and degree of intracellular activity in surface bacteria was significantly lower than bacteria derived from the bottom-ice layer. A possible interpretation of this finding is that only slowgrowing psychrophilic species are capable of acclimating to both reduced temperature and high salinity. The current study supports this supposition as the psychrophilic bacteria (T-B) did not respond quickly to the algal-derived DOM. Interestingly, although variation in the abundance of bacteria in the flipped cores was insignificant after a period of $18 \mathrm{~d}$, I do provide evidence for a shift in the dominant phylotypes of the bacterial population originally at the surface of the ice (Table 5.4, Figure 5.5, Figure 5.6b). This shift in community composition may preclude a significant growth response by pre-existing bacterial taxa, or indicate colonisation by cells present in the water column or surrounding ice.

The primers $357 \mathrm{~F}$ and $518 \mathrm{R}$ were chosen in this study to maximise the band-based characterisation of phylotypes using DGGE (see Sánchez et al. 2007). As a trade-off, we accepted reduced amplicon length (160 bp) with which to obtain phylogenetic information. Importantly, a number of bands at different locations on different gels had similar sequences (Figure 5.8, Table 5.6). While this may reflect the limited nucleotide resolution, we acknowledge the various biases that are inherent to DGGE analysis, including DNA extraction efficiency, rRNA gene copy number and PCR primer annealing efficiency (see Reysenbach et al. 1992, Farrelly et al. 1995, for reviews). However, with the exception of one excised band (B-1) the excised DGGE 
bands showed acceptable ( $>90 \%$ ) similarity to $\alpha$-Proteobacteria, $\gamma$-Proteobacteria and Firmicutes sequences from polar regions, and high bootstrap support for these groupings was obtained in construction of a neighbour-joining tree (Figure 5.9).

\subsubsection{Resistance, resilience, or redundancy in sea-ice microbial communities?}

Increasing evidence suggests that microbes are of high relevance to ecosystem processes and that a predictive framework is needed to interpret the ecological consequences of changes in community composition (Allison \& Martiny 2008). However, in many ecosystems, the prerequisite studies that quantify the microbial response to environmental disturbance are lacking. The extent to whether sea-ice microbes are resistant, resilient, or even functionally redundant, is of fundamental importance given the projected reduction in the volume and extent of annual sea-ice over the coming decades (Rind et al. 1997, Meehl et al. 2000, Arrigo \& Thomas 2004). By conducting a reciprocal transplant experiment I examined the in situ responses of microbes to habitat variability for the first time in Antarctic sea-ice. I show that although discrete microbial assemblages are functionally similar within the ice, they are not functionally redundant. This is largely due to the seasonal development of the microbial community, which is finely attuned to physicochemical variation within the ice. Although the concentration of DOM available for bacterial metabolism was enhanced in the flipped ice cores, I observed a 'malfunctioning' of the microbial loop during the experimental period of $18 \mathrm{~d}$. In general, the degree of resilience exhibited by sea-ice bacteria appears to be higher than that of microalgae, however I suggest that reduced ambient temperature (B-T) and specific community composition (T-B) limited the assimilation of DOM by the respective assemblages. The ability of microalgae to regulate the composition and concentration of 
photosynthetic pigments is a particularly advantageous response to variation in ambient irradiance, however I illustrate that a rapid disturbance causes significant physiological stress. The experimental design adopted in this study confers a significant advantage over in vitro methods that rely on melted ice cores or extracted brine and these results provide a new and unique insight into microbial dynamics in the Antarctic sea-ice ecosystem.

\subsection{Literature Cited}

Ackely SF, Sullivan CW (1994) Physical controls on the development and characteristics of Antarctic sea ice biological communities - a review and synthesis. Deep-Sea Research 41: 1583-1604.

Allison SD, Martiny JBH (2008) Resistance, resilience, and redundancy in microbial communities. Proceedings of the National Academy of Science 105: 11512-11519.

Anderson MJ (2001) A new method for non-parametric multivariate analysis of variance. Austral Ecology 26: 32-46.

Anderson MJ (2006) Distance-based tests for homogeneity of multivariate dispersions. Biometrics 62: 245-253.

Anderson MJ, Ellingsen KE, McArdle BH (2006) Multivariate dispersion as a measure of beta diversity. Ecology Letters 9: 683-693.

Archer SD, Leakey RJG, Burkill PH, Sleigh MA, Appleby CJ (1996) Microbial ecology of sea ice at a coastal Antarctic site: community composition, biomass and temporal change. Marine Ecology Progress Series 135: 179-195.

Arrigo KR, Sullivan CW (1992) The influence of salinity and temperature covariation on the photophysiological characteristics of Antarctic sea ice microalgae. Journal of Phycology 28: 746-756.

Arrigo KR, Thomas DN (2004) Large scale importance of sea ice biology in the Southern Ocean. Antarctic Science 16: 471-486.

Arrigo KR, Lizotte MP, Dixon P, Dieckmann G (1997) Primary prodution in Antarctic sea ice. Science 276: 394-397.

Arrigo KR, Worthen D, Schnell A, Lizotte M (1998) Primary production in Southern Ocean waters. Journal of Geophysical Research 103: 15587-15600.

Azam F, Malfatti F (2007) Microbial structuring of marine ecosystems. Nature Reviews Microbiology 5: 782-791.

Azam F, Smith DC, Hollibaugh JT (1991) The role of the microbial loop in Antarctic pelagic ecosystems. Polar Research 10: 239-243.

Bray JR, Curtis JT (1957) An ordination of the upland forest communities of southern Wisconsin. Ecological Monographs 27: 325-349.

Clarke KR, Green RH (1988) Statistical design and analysis for a 'biological effects' study. Marine Ecology Progress Series 46: 213-226.

Clarke KR, Warwick RM (2001) Change in marine communities, $2^{\text {nd }}$ edition. PRIMER-E Ltd, Plymouth.

Cox GFN, Weeks WF (1986) Changes in the salinity and porosity of sea-ice samples during shipping and storage. Journal of Glaciology 32: 371-375. 
Delille D, Fiala M, Rosiers C (1992) Marine bacterioplankton at the Weddell Sea ice edge, distribution of psychrophilic and psychrotrophic populations. Polar Biology 12: 205210.

Delille D, Fiala M, Rosiers C (1995) Seasonal changes in phytoplankton and bacterioplankton distribution at the ice-water interface in the Antarctic neritic area. Marine Ecology Progress Series 123: 225-233.

Delille D, Fiala M, Kuparinen J, Kuosa H, Plessis C (2002) Seasonal changes in microbial biomass in the first-year ice of the Terre Adélie area (Antarctica). Aquatic Microbial Ecology 28: 257-265.

Deming JW (2002) Psychrophiles and polar regions. Current Opinion in Microbiology 5: 301-309.

Evans CA, O'Reilly JE, Thomas JP (1987) A handbook for the measurement of chlorophyll a and primary production. College Station,Texas A\&M University, 114p.

Farrelly V, Rainey FA, Stackebrandt E (1995) Effect of genome size and rRNA gene copy number on PCR amplification of 16S rRNA genes from a mixture of bacterial species. Applied and Environmental Microbiology 61: 2789-2801.

Fiala M, Kuosa H, Kopczyńska EE, Oriol L, Delille D (2006) Spatial and seasonal heterogeneity of sea ice microbial communities in the first-year ice of Terre Adélie area (Antarctica). Aquatic Microbial Ecolology 43:95-106.

Fritsen CH, Coale SL, Neenan DR, Gibson AH, Garrison DL (2001) Biomass, production and microhabitat characteristics near the freeboard of ice floes in the Ross Sea, Antarctica, during the austral summer. Annals of Glaciology 33: 288-296.

Garrison DL (1991) Antarctic Sea Ice Biota. American Zoologist 31: 17-33.

Garrison DL, Gibson A, Coale SL, Gowing, MM, Okolodkov YB, Fritsen HF, Jeffries MO (2005) Sea-ice microbial communities in the Ross Sea: autumn and summer biota. Marine Ecology Progress Series 300: 39-52.

Gowing MM, Garrison DL, Gibson AH, Krupp JM, Jefferies MO, Fritsen CH (2004) Bacterial and viral abundances in Ross Sea summer pack ice communities. Marine Ecology Progress Series 279: 3-12.

Giesenhagen HC, Detmer AE, de Wall J, Weber A, Gradinger RR, Jochem, FJ (1999) How are Antarctic planktonic microbial food webs and algal blooms affected by melting of sea ice? Microcosm simulations. Aquatic Microbial Ecology 20: 183-201.

Griffith GP, Vennell R, Lamare MD (2009) Diadinoxanthin cycle of the bottom ice algae community during spring in McMurdo Sound, Antarctica. Polar Biology 32: 623-636.

Grossi SM, Kottmeier ST, Sullivan CW (1984) Sea ice microbial communities III. Seasonal abundance of microalgae associated bacteria in McMurdo Sound, Antarctica. Microbial Ecology 10: 231-242.

Grossmann S, Gleitz M (1993) Microbial responses to experimental sea-ice formation: implications for the establishment of Antarctic sea-ice communities. Journal of Experimental Marine Biology and Ecology 173: 273-289.

Günther S, Gleitz M, Dieckmann GS (1999) Biogeochemistry of Antarctic sea ice: a case study on platelet ice layers at Drescher Inlet, Weddell Sea. Marine Ecology Progress Series 177: 1-13.

Junge K, Krembs C, Deming J, Stierle A, Eicken H (2001) A microscopic approach to investigate bacteria under in situ conditions in sea-ice samples. Annals of Glaciology 33: 304-310.

Kottmeier ST, Sullivan CW (1988) Sea Ice Microbial Communities IX. Effects of temperature and salinity on metabolism and growth of autotrophs and heterotrophs. Polar Biology 8: 293-304

Kottmeier ST, McGrath Grossi S, Sullivan CW (1987) Sea ice microbial communities. VIII. Bacterial production in annual sea ice of McMurdo Sound, Antarctica. Marine Ecology Progress Series 35: 175-186

Krembs C, Eicken H, Junge K, Demming J (2002) High concentrations of exopolymeric substances in Arctic winter ice: implicationsfor the polar ocean carbon cycle and cryoprotection of diatoms. Dee-Sea Research I 49: 2163-2181. 
Legendre L, Ackley SF, Dieckmann, GS, Gulliksen B, Horner R, Hoshiai T, Melnikov IA, Reeburgh WS, Spindler M, Sullivan CW (1992) Ecology of sea ice biota. 2. Global Significance. Polar Biology 12: 429-444.

Lazzara L, Nardello I, Ermanni C, Mangoni O, Saggiomo V (2007) Light environment and season dynamics of microalgae in the annual sea ice at Terra Nova Bay, Ross Sea, Antarctica. Antarctic Science 19: 83-92.

Lizotte, (2001) The contribution of sea ice algae to Antarctic marine primary production. American Zoologist 41: 57-73.

Mangoni O, Carrade GC, Modigh M, Catalano G, Saggiomo V (2009) Photoacclimation in Antarctic bottom ice algae: an experimental approach. Polar Biology 32: 325-335.

Manly BFJ (2006) Randomisation, bootstrap and monte carlo methods in biology, $3^{\text {rd }}$ edition. Chapman \& Hall, London, 455p.

Martin A, Hall JA, O’Toole R, Davy SK, Ryan KG (2008) High single-cell metabolic activity in Antarctic sea ice bacteria. Aquatic Microbial Ecology 52: 25-31.

Martin A, Hall JA, Ryan KG (2009) Low salinity and high-level UV-B radiation reduce single-cell activity in Antarctic sea ice bacteria. Applied and Environmental Microbiology 75: 7570-7573.

Martin A, Hall JA, Miller HC, Ryan KG (In review) Can microcosm simulations be used to infer microbial loop dynamics in Antarctic sea ice? In review: Marine Biology.

Maykut GA, Grenfell TC (1975) The spectral distribution of light beneath first-year sea ice in the Arctic Ocean. Limnology and Oceanography 20: 554-563.

McArdle BH, Anderson MJ (2001) Fitting multivariate models to community data: a comment on distance-based redundancy analysis. Ecology 82: 290-297.

McMinn A, Ashworth C, Ryan KG (1999b) Growth and productivity of Antaractic sea ice algae under PAR and UV irradiances. Botanica Marina 42: 401-407.

McMinn A, Ashworth C, Ryan KG (2000) In situ net primary productivity of an Antarctic fast ice bottom algal community. Aquatic Microbial Ecology 21: 177-185.

McMinn A, Skerratt J, Trull T, Ashworth C, Lizotte M. (1999a) Nutrient stress gradient in the bottom $5 \mathrm{~cm}$ of fast ice, McMurdo Sound, Antarctica. Polar Biology 21: 220-227.

Meehl GA, Collins WD, Boville BA, Kiehl JT, Wigley TML, Arblaster JM (2000) Response of the NCAR climate system model to increased $\mathrm{CO} 2$ and the role of physical processes. Journal of Climate 13: 1879-1898.

Meiners K, Brinkmeyer R, Granskog MA, Lindfors A (2004) Abundance, size distribution and bacterial colonization of exopolymer particles in Antarctic sea ice (Bellingshausen Sea). Aquatic Microbial Ecology 35: 283-296.

Mock T, Kroon BMA (2002) Photosynthetic energy conversion under extreme conditions. I. Important role of lipids as structural modulators and energy sink under $\mathrm{N}$-limited growth in Antarctic sea ice diatoms. Hydrobiology 470: 127-132.

Mock T, Thomas DN (2005) Recent advances in sea-ice microbiology. Environmental Microbiology 7: 605-619.

Monfort P, Demers S, Levasseur M (2000) Bacterial dynamics in first year sea ice and underlying seawater of Saroma-ko lagoon (Sea of Okhotsk, Japan) and Resolute passage (high Canadian arctic): inhibitory effects of ice algae on bacterial dynamics. Canadian Journal of Microbiology 46: 623-632.

Murray AE, Grzymski JJ (2007) Diversity and genomics of Antarctic marine microorganisms. Philosophical Transactions of The Royal Society of London B 362: 225-2271.

Murray AE, Hollibaugh JT, Orrego C (1996) Phylogenetic compositions from two California estuaries by denaturing gradient gel electrophoresis of $16 \mathrm{~S}$ rDNA fragments. Applied and Environmental Microbiology 62: 2676-2680

Palmisano AC, Sullivan CW (1983) Sea-ice microbial communities (SIMCO). I. Districution, abundance, and primary production of ice microalgae in McMurdo Sound, Antarctica in 1980. Polar Biology 2: 171-177.

Palmisano AC, SooHoo JB, Sullivan CW (1985) Photosynthesis-irradiance relationships in sea ice microalgae from McMurdo Sound, Antarctica. Journal of Phycology 21: 341346. 
Pusceddu A, Dell' Anno A, Vezzulli L, Fabiano M, Saggiomo V, Cozzi S, Catalano G, Guglielmo L (2009) Microbial loop malfunctioning in the annual sea ice at Terra Nova Bay (Antarctica). Polar Biology 32: 337-346.

Reed HE, Martiny JBH (2007) Testing the functional significance of microbial communities in natural communities. FEMS Microbiology Ecology 62: 161-170.

Reysenbach AL, Giver LJ, Wickham GS, Pace NR (1992) Differential amplification of rRNA genes by polymerase chain reaction. Applied and Environmental Microbiology 58: 3417-3418.

Rind D, Healy R, Parkinson C, Martinson D (1997) The role of sea ice in 2xCO2 climate sensitivity: part II: hemispheric dependencies. Geophysical Research Letters 23: 14911494.

Ryan KG, Ralph P, McMinn A (2004) Acclimation of Antarctic bottom-ice algal communities to lowered salinities during melting. Polar Biology 27: 679-686.

Ryan KG, McMinn A, Mitchell KA, Trennery L (2002) Mycosporine like amino acids in Antarctic sea ice algae, and their response to UVB radiation. Zeitschrifft fur Naturforshhung C 57: 461-477.

Ryan KG, Cowie R, Liggins L, McNaughtan D, Martin A, Davy S (2009) The short-term effect of irradiance on the photosynthetic properties of Antarctic fast-ice microalgal communities. In press: Journal of Phycology.

Ryan KG, Hegseth E, Martin A, Davy S, O'Toole R, Ralph P, McMinn A, Thorn C (2006) Abundance and distribution of the microalgal community within sea ice along a latitudinal gradient in the Ross Sea. Antarctic Science 18: 583-594.

Sánchez O, Gasol JM, Massana R, Mas J, Pedrós-Alió C (2007) Comparison of different denaturing gradient gel electrophoresis primer sets for the study of marine bacterioplankton communities. Applied and Environmental Microbiology 73: 59625967.

Stewart FJ, Fritsen CH (2004) Bacteria-algae relationships in Antarctic sea ice. Antarctic Science 16: 143-156.

Swofford DL (2002) PAUP* Phylogenetic analysis using parsimony (*and other methods). Version 4. Sunderland, MA: Sinauer Associates.

Thomas DN, Dieckmann GS (2002) Antarctic sea ice - a habitat for extremophiles. Science 295: 641-644.

Thomas DN, Kattner G, Engbrodt R, Giannelli V, Kennedy H, Haas C, Dieckmann GS (2001) Dissolved organic matter in Antarctic sea ice. Annals of Glaciology 33: 297-303.

Thompson JD, Higgins DG, Gibson TJ (1994) CLUSTAL W: improving the sensitivity of progressive multiple sequence alignment through sequence weighting, positions-specific gap penalties and weight matrix choice. Nucleic Acids Research 22: 4673-4680. 


\section{CHAPTER 6}

The microbial loop: full circle and future prospects

\subsection{Introduction}

I examined microbial dynamics in the Antarctic sea-ice ecosystem by exploring the metabolic pathway that links heterotrophic bacteria and phototrophic microalgae. The bacterial assimilation of algal-derived DOM is of fundamental importance to the microbial loop, and for the first time I provide evidence of this dynamic beyond the use of bulk biomass comparisons. Using a combination of physiological, genetic, and spatial analyses, I determined the extent to which DOM exuded by microalgae serves as a growth substrate for sea-ice bacteria. This was demonstrated by instigating a malfunction in the microbial loop and documenting changes in bacterial metabolic activity, cell abundance and community composition. By investigating this pathway at a range of spatial (both in vitro and in situ) and temporal (8 hours to 18 days) scales, I provide a new and unique insight into microbial dynamics in Antarctic seaice.

\subsection{Summary of findings}

The main findings from each of the four data chapters are summarised below:

\subsubsection{Chapter 2 - High single-cell metabolic activity in Antarctic sea-ice bacteria}

In comparison to the uptake of radiolabeled amino acids, single-cell analysis provides a significantly finer degree of experimental resolution in estimating metabolic activity in bacterial cells. Sea-ice bacteria derived from the congelation 
(bottom) layer of annual Antarctic fast-ice during the austral spring exhibit high single-cell activity, as was illustrated for the first time in this study. In general, a consensus among techniques was observed with respect to active (capable of reducing CTC or those with high rRNA content) and viable (having intact cell membranes) bacterial cells. However, for establishing a real-time metabolic response in short-term manipulative experiments, CTC was deemed to be the most appropriate method. The congelation layer of annual fast-ice is typically saturated with DOM in the austral spring, and restricting the supply of photosynthate by removing the majority of microalgal cells or incubating in the dark had no effect on bacterial metabolism within a period of 8 hours.

\subsubsection{Chapter 3 - Melting moments: low salinity and high UV-B radiation reduce single-cell activity in Antarctic sea-ice bacteria}

In contrast to the microalgal component of the community, physiological stress and the response to experimental stimuli remains understudied in sea-ice bacteria. Simulating the process of annual ice melt by exposing cells to low salinity seawater and high UV-B radiation significantly reduced single-cell metabolic activity $(\mathrm{CTC}+$ cells) in bacteria derived from the congelation layer of annual fast-ice. Given the current ambiguity associated with single-cell analyses, in particular the CTC assay, the response to salinity was verified at the community level by examining the uptake of $\left[{ }^{3} \mathrm{H}\right]$ leucine. In contrast to ice melt, simulating the process of ice formation by exposing cells to high salinity and low light did not restrict the bacterial reduction of CTC. Light and salinity stress on the production of photosynthate by microalgae subsequently exerted a weak, but negative, influence on bacterial metabolism after 48 hours. However by restricting microalgal photosynthesis with 3-(3,4dichlorophenyl)-1,1-dimethylurea (DCMU), or removing the majority of microalgal 
cells prior to incubation, a significant reduction in the percentage of CTC+ bacteria was observed.

\subsubsection{Chapter 4 - Can microcosm simulations be used to infer microbial loop dynamics in Antarctic sea-ice?}

Controlling factors of interest in microcosm simulations is a useful methodology with which to enhance resolution in manipulative experiments. This technique was applied for the first time to sea-ice microbial communities derived from both the congelation layer and high-brine region of annual fast-ice. After an incubation period of 5 days, an increase in the abundance of bacterial cells was observed in both simulations. At the conclusion of the experiment (day 9), photosynthate limitation in DCMU-treated cultures had restricted the growth of bacteria in the brine microcosm and significantly influenced community composition with respect to bacterial phylotypes obtained with denaturing gradient gel electrophoresis (DGGE). In contrast, DCMU had only a limited effect on bacterial growth in the bottom-ice microcosm and did not influence DGGE band patterns. The percentage of metabolically active $(\mathrm{CTC}+)$ brine bacteria was relatively low compared to cells derived from the congelation layer, and this is most likely due to variability in the concentration of DOM. Interestingly, there was no significant difference in either metabolic activity or abundance of bacteria incubated in the dark or exposed to a light/dark regime. Grazing by phagotrophic protozoa may have influenced the concentration of microalgae in both experiments, as inferred by changes in the concentration of chlorophyll $a$. Bacterivory accounted for a significant loss of cells in the bottom-ice microcosm between days 5 and 9 , and bacterivorous grazing was also evident in the brine microcosm. 


\subsubsection{Chapter 5 - In situ response of sea-ice microbes to habitat variability: insight into microbial dynamics, or just another 'flippin' ice core?}

A reciprocal transplant experiment was conducted for the first time in Antarctic seaice by reinserting cores into the ice matrix upside down. By combining both uni- and multivariate statistical methods, changes in the abundance and taxonomic composition of discrete microbial assemblages (top, middle, and bottom) was examined by comparing the flipped cores with a series of experimental controls. In addition, light and temperature loggers were embedded within the ice and this data was used to characterise the in situ physicochemical variability. Results contribute to the few studies that have described changes in the composition of microalgae or bacteria through the ice profile, and the flipped cores illustrate the extent to which microbial assemblages are attuned to specific microhabitats.

Limited assimilation of algal-derived DOM by bacteria in the top or bottom of the flipped cores illustrated a 'malfunctioning' of the microbial loop. Bacterial growth appeared to be temperature-limited in the top of the flipped cores, while a lack of growth after 18 days in near-surface bacteria exposed to the ice/water interface was attributed to a community dominated by slow-growing extremely psychrophilic species. A stronger physiological response to disturbance was elicited by microalgae and significant growth was contrasted with severe bleaching and cell death. The reciprocal transplant methodology offers a unique insight into community dynamics, and findings suggest that the in situ development of the microbial community results in assemblages that are functionally similar, but not functionally redundant. 


\subsection{Discussion and synopsis}

Productivity in ice-covered regions of the Southern Ocean reflects not only the spatial and temporal dynamics of the sea-ice ecosystem, but also the complex cycling of energy through the microbial community. An active microbial loop has important implications for sea-ice trophodynamics, but the significance of DOM for bacterial production within annual sea-ice, and marine systems in general, remains speculative (Thomas et al. 2001, Gasol et al. 2008, Pusceddu et al. 2009).

The contribution of individual bacterial cells to respiration, remineralisation and trophic interactions is largely determined by their metabolic status (Davidson et al. 2004). Intracellular reduction of CTC by sea-ice bacteria derived from both the congelation and surface high-brine regions of the ice is significantly higher than other marine systems (Chapter 2, Chapter 3, Chapter 4). In addition, $80 \%$ of the cells present in the congelation layer have a ribosomal content that can be detected by fluorescence in situ hybridisation and $>68 \%$ of these cells have intact cell membranes (Chapter 2). These single-cell data provide an important insight into the activity of sea-ice bacteria in the austral spring by highlighting that bacteria are responsive to the physiochemical conditions in the ice and actively involved in trophic dynamics.

The seasonal increase of bacterial cells is well documented, particularly in the congelation layer of the ice (Sullivan \& Palmisano 1984, Chapter 5). The extent to which microalgae provide the required substrate remains equivocal. For example, temporal variation in the accumulation of the two major constituents of DOM, dissolved organic carbon (DOC) and dissolved organic nitrogen (DON) can result in 
highly variable DOC/DON ratios and these are not always found to correlate with the in situ microbial biomass (eg. Thomas et al. 2001, Thomas \& Dieckmann 2002). Furthermore, Pusceddu et al. (2009) have recently documented a reduction in bacterial production in annual fast-ice during the austral spring, despite the accumulation of algal-derived DOM. These authors suggest that algal-derived bactericidal and/or bacteriostatic compounds can in fact restrict the growth of prokaryotes.

While heterotrophic bacteria can contribute directly to the generation of growth substrates, either through autolysis or viral lysis (Gasol et al. 2008), very few studies have actually measured the production and fate of DOM within the ice (but see Thomas et al. 2001, Misic et al. 2006, Cozzi 2008). The analysis of the biochemical structure of DOM is relatively complex, due in part to difficulties in concentrating DOM and the ease with which it can be contaminated (Mopper et al. 1996). Importantly, these analyses provide only a 'snapshot' of the biochemical environment, and do not actively trace the metabolic links between the key microbial taxa.

An alternative methodology that was adopted in this thesis was to compare microbial communities from two regions of the ice profile with significantly different concentrations of DOM (Chapter 4). Although the in situ dynamic is considerably more complex, given that photon flux, nutrient stress and mechanical damage influence the release of photosynthate by microalgae (Thomas et al. 2001, Cozzi 2008), these variable are not confounded under controlled culture conditions. In comparison to bacteria derived from the congelation layer of the ice, intracellular 
activity and the subsequent growth rate of bacteria originating from brine channels was substantially lower. Reduced metabolic activity and production is indicative of substrate or temperature limitation, but this was confirmed by using DCMU to restrict microalgal photosynthesis. DCMU halts photosynthesis in microalgae by specifically inhibiting the reoxidation of reduced coenzyme $\mathrm{Q}$, which is the primary electron acceptor of the PS II photosynthetic reaction centre (Karl 2003).

Historically, such inhibitors have been avoided due to concerns that they provide bacterial growth substrates or interrupt grazer metabolism (Caron 2001). However, a recent examination of litter-inhabiting microbiota found no evidence for non-target effects of DCMU on heterotrophic microbial processes (Francoeur et al. 2007). Findings presented in Chapter 3 and Chapter 4 support this conclusion. Importantly, the photosynthate released by microalgae is the major stimulus for bacterial growth, at least in vitro (Chapter 3, Chapter 4). Furthermore, an increase in the availability of DOM, such as occurs during the dissolution of the ice matrix, elicits a rapid metabolic response in sea-ice bacteria (Chapter 3, Giesenhagen et al. 1999). This short-term response indicates that the growth substrate consists of labile compounds, specifically the sugars and amino acids associated with microalgal photosynthate.

All evidence suggests that a functional microbial loop operates during the seasonal development of the sea-ice community (Stewart \& Fritsen 2004) but this has never been demonstrated beyond the use of 'snapshot' assessments that correlate microbial abundance or production. Although repeat sampling has been used to effectively document temporal succession in the relative abundance of microalgae, bacteria and protozoa and thereby qualify the in situ flow of energy through the community (eg. Archer et al. 1996, Garrison et al. 2005), a quantitative assessment of how 
physicochemical variability influences coupling between bacteria and microalgae is lacking. Monitoring the response of microbes in an ephemeral habitat to disturbance may appear counterintuitive, but validating metabolic flexibility and the extent to which sea-ice microbes are physiologically tolerant, needs to be resolved using in situ methods. Many ecosystems do not permit the composition of microbes to be directly manipulated, but if different microbial communities are observed to produce different process rates in a common environment, then it can be inferred that compositional differences are responsible for the functional differences (Allison \& Martiny 2008). Experimental designs that provide insight into both community composition and function, such as reciprocal transplants, are particularly suited to the sea-ice environment. This approach was used to determine whether microbes are attuned to discrete microhabitats within the ice and examine the influence of environmental variables on trophic dynamics (Chapter 5). Although the status of microbial populations in cores that were flipped and reinserted into the ice matrix upside down was assessed after a relatively short period of time (18 d), this was sufficient in showing how ecosystem processes such as the microbial loop are driven by microbial assemblages within the ice that can be considered unique.

Resilience, or the rate at which a community returns to its original composition following a disturbance event, is a significant indicator of microbial adaptation (Allison \& Martiny 2008). With respect to autotrophic microalgae in the sea-ice ecosystem, taxonomic variation is somewhat limited and assemblages are typically dominated by several taxa such as Fragilariopsis curta, Fragilariopsis cylindrus and Nitzchia stallata (Chapter 5). However, these cells cannot be considered as being functionally redundant (the new community fulfils a similar ecological role). This is 
due primarily to the allocation and concentration of intracellular photosynthetic pigments and secondarily to the degree of physiological stress that can be tolerated by microalgae with respect to temperature, salinity and the availability of nutrients. Of most significance in considering ecosystem processes is the fact that, regardless of the origin of the accumulated cells in the bottom of the flipped cores, the congelation layer of the ice is highly resilient to disturbance. In contrast, the nearsurface habitat represents a significantly harsher physicochemical environment and the abundance of cells in both the top and middle regions of the ice is relatively depauperate. Adaptation by highly shade-adapted cells to this region of the ice has been shown experimentally, at least with regard to increased irradiance (Griffith et al. 2009, Mangoni et al. 2009). The suite of adaptive physiological traits notwithstanding, the active contribution of microalgae to the microbial loop following rapid exposure to high light is unlikely to be significant, although chlorophyll $a$ was still present in the surface of the flipped cores after 18 days (Chapter 5). This study was the first of its kind to quantify the response of microalgae to habitat variability within the spatial confines of the ice matrix.

Culture-independent techniques such as DGGE have now become an established alternative to morphological-based identifications in the analysis of bacterial assemblages (Casamayor et al. 2000, Gast et al. 2004). While more empirical research is clearly needed to establish the links between the physiology, taxonomic diversity and functional significance of sea-ice bacteria, DGGE is a particularly useful tool with which to examine changes in community composition (Chapter 4, Chapter 5). Due to relatively short generation times and a high degree of structural simplicity, the bacterial component of the sea-ice community is more likely to be 
resistant to disturbance, or at the very least resilient. However, results suggest that, like the microalgal community, bacteria are not functionally redundant within the ice but are attuned to discrete habitats. Assuming that the concentration of labile DOM increased at either end of the flipped cores, then uncoupling of the microbial loop can be attributed to changes in bacterial community composition (Chapter 5). Bearing in mind the experimental period was limited to 18 days, the delayed response in the bacterial assimilation of algal-derived DOM has important implications for the microbial loop. Importantly, the taxonomic diversity of sea-ice bacteria is shown to vary with depth. While the general trend for an increase in psychrophilic species in the congelation layer is well known (Thomas \& Dieckmann 2002), DGGE profiles from higher up the ice profile imply that bacteria exhibit species-specific environmental tolerances. Bacterial assemblages are characterised by reduced species richness in this region of the ice and although what is essentially a depauperate community may have influenced the amplification of 16S rRNA genes, there is potentially increased heterogeneity (Chapter 5). In addition, adaptation to the highbrine surface region is indicative of a specialist community that is extremely psychrophilic. The metabolic activity and growth rate of cells is lower in bacteria that are derived from the high-salinity, low- temperature environment, and the contribution to ecosystem processes is significantly slower, even under conditions where the concentration of DOM is enhanced (Chapter 4, Chapter 5).

A mechanistic understanding of productivity and trophodynamics in the Antarctic sea-ice ecosystem will ultimately require techniques that probe the spatial confines of the ice matrix. However, increasing evidence suggests that the sea-ice community is of high relevance to ecosystem processes in ice-covered regions of the Southern 
Ocean. Linking the spatial and temporal variability inherent to the sea-ice system with the taxonomic diversity and functional capabilities of ice-associated microbes poses a significant challenge, but this will integral be to the development of prognostic models that qualify the resilience of the sea-ice community to climate change. The data presented in this thesis are an important step towards achieving that goal.

\subsection{Recommendations for future research}

This thesis has investigated the metabolic pathway that links heterotrophic bacteria and phototrophic microalgae and provides a new and unique insight into microbial dynamics in Antarctic sea-ice. Throughout the course of this research a number of new questions have arisen that may extend the findings presented in this thesis.

\section{What is the in situ metabolic status of sea-ice bacteria?}

The technique developed by Junge et al. (2001) now allows bacterial cells within thin sections of sea-ice to be stained with DAPI and subsequently visualised within the three-dimensional framework of brine inclusions. Adapting this technique to determine metabolic activity using single-cell analysis with an assay such as CTC is an exciting prospect for future work.

\section{What is the taxonomic diversity of sea-ice bacteria?}

Molecular biological methods utilising the gene sequences that encode the small subunit rRNA gene have developed into powerful tools for the cultureindependent identification of aquatic microorganisms (Pernthaler 2005). While DGGE was effective in providing a fingerprint of bacterial assemblages from various regions within the ice (Chapter 4, Chapter 5), the taxonomic diversity of 
ice-associated microbes has yet to be fully resolved. A complimentary approach that combines newer culture-independent techniques such as T-RFLP and in particular 454 pyrosequencing would allow significantly greater insight into the diversity of sea-ice bacteria.

3. To what extent do bacterial communities vary across geographical regions? What physical and/or biological processes drive this process?

Data presented in this thesis illustrate significant variability in the vertical distribution of bacteria, particularly with respect to metabolic activity, cell abundance and to a lesser extent community composition. Although temporal variation in the abundance of bacterial cells has been well characterised, the extent to which community composition varies spatially, is largely unknown. Characterising bacterial communities from a number of geographical regions and correlating community structure with important environmental factors such as solar radiation (annual radiation, UV radiation), temperature, day length and seaice cover would provide a useful insight into community dynamics.

\section{How important is bacterial secondary production to microbial loop} dynamics?

Although the in situ consumption of sea-ice bacteria by phagotrophic protozoa is integral to the microbial loop, this trophic link has received remarkably little attention. More research is needed on the functional ecology of flagellates and ciliates and in particular the cycling of energy to higher trophic levels when these organisms are released back into the water column. In situ grazing could be inferred by the uptake of fluorescently labelled beads (a surrogate for bacteria) combined with dilution experiments (see Landry \& Hassett 1982) to examine grazing pressure on microalgae. 


\section{Are sea-ice bacteria light sensitive?}

Proteorhodopsins (PRs) are light-harvesting proteins that allow for the synthesis of ATP in prokaryotes. Although there have been no reports of PR-bacteria in sea- ice, or any other form of bacterial phototrophy, unpublished preliminary results suggest otherwise. Given the stratified nature of the ice matrix, this is the ideal environment to determine variation in PR expression within the ice and validate the ecological significance of this gene.

\section{Is the microbial loop an early indicator of climate change?}

A reduction in the volume and extent of annual sea-ice is likely to have a profound effect on productivity in the Southern Ocean. Although the expected $25 \%$ loss of annual ice over the next century may increase net primary production by approximately $10 \%$ (Arrigo \& Thomas 2004), the consequences for the Antarctic coastal region are likely to be negative. While the implications for seaice microbes and the microbial loop are difficult to predict, comparing a region with stable sea-ice formation such as the Ross Sea with a region such as the Antarctic Peninsula which has become relatively unstable, is considered timely.

\subsection{Literature cited}

Allison SD, Martiny JBH (2008) Resistance, resilience, and redundancy in microbial communities. Proceedings of the National Academy of Science of the United States of America 105: 11512-11519.

Arrigo KR, Thomas DN (2004) Large scale importance of sea ice biology in the Southern Ocean. Antarctic Science 16: 471-486.

Casamayor EO, Schäfer H, Bańeras L, Pedrós-Alió C, Muyzer G (2000) Identification of and spatio-temporal differences between microbial assemblages from two neighboring sulfurous lakes: comparison by microscopy and denaturing gradient gel electrophoresis. Applied and Environmental Microbiology 66: 499-508.

Cozzi S (2008) High-resolution trends of nutrients, DOM and nitrogen uptake in the annual sea ice at Terra Nova Bay, Ross Sea. Antarctic Science 20: 441-454. 
Davidson AT, Thomson PG, Westwood K, van den Enden R (2004) Estimation of bacterioplankton activity in Tasmanian coastal waters and between Tasmania and Antarctica using stains. Aquatic Microbial Ecology 37: 33-45.

Francoeur SN, Johnson AC, Kuehn KA, Neely RK (2007) Evaluation of the efficacy of the photosystem II inhibitor DCMU in periphyton and its effects on nontarget microorganisms and extracellular enzymatic reactions. Journal of the North American Benthological Society 26: 633-641.

Garrison DL, Gibson A, Coale SL, Gowing, MM, Okolodkov YB, Fritsen HF, Jeffries MO (2005) Sea-ice microbial communities in the Ross Sea: autumn and summer biota. Marine Ecology Progress Series 300: 39-52.

Gasol JM, Pinhassi J, Alonso-Sáez L, Ducklow H, Herndl GJ, Koblížek M, Labrenz M, Luo Y, Morán XAG, Reinthaler T, Simon M (2008) Towards a better understanding of microbial carbon flux in the sea. Aquatic Microbial Ecology 53: 21-38.

Gast RJ, Dennett MR, Caron DA (2004) Characterization of protistan assemblages in the Ross Sea, Antarctica, by denaturing gradient gel electrophoresis. Applied and Environmental Microbiology 70: 2028-2037.

Giesenhagen HC, Detmer AE, de Wall J, Weber A, Gradinger RR, Jochem, FJ (1999) How are Antarctic planktonic microbial food webs and algal blooms affected by melting of sea ice? Microcosm simulations. Aquatic Microbial Ecology 20: 183-201.

Griffith GP, Vennell R, Lamare MD (2009) Diadinoxanthin cycle of the bottom ice algae community during spring in McMurdo Sound, Antarctica. Polar Biology 32: 623-636.

Karl DM (1986) Determination of in situ microbial biomass, viability, metabolism, and growth In: Poindexter JS, Leadbetter ER (eds) Bacteria in nature, vol 2. Plenum Publishing Corp., p 81-176.

Landry MR, Hassett RP (1982) Estimating the grazing impact of marine microzooplankton. Marine Biology 67: 283-288.

Mangoni O, Carrade GC, Modigh M, Catalano G, Saggiomo V (2009) Photoacclimation in Antarctic bottom ice algae: an experimental approach. Polar Biology 32: 325-335.

Misic C, Castellano M, Ruggieri N, Povero P (2006) Dissolved organic matter characterisation and temporal trends in Terra Nova Bay (Ross Sea, Antarctica). Estuarine, Coastal and Shelf Science. 70: 405-414.

Mopper K, Feng Z, Bentjen SB, Chen RF (1996) Effects of cross-flow filtration on the absorption and fluorescence properties of seawater. Marine Chemistry 55: 53-74.

Pernthaler J, Amman R (2005) Fate of heterotrophic microbes in pelagic habitats: focus on populations. Microbiology and Molecular Biology Reviews 69: 440-461.

Pusceddu A, Dell'Anno A, Vezzulli L, Fabiano M, Saggiomo V, Cozzi S, Catalano G, Guglielmo L (2009) Microbial loop malfunctioning in the annual sea ice at Terra Nova Bay (Antarctica). Polar Biology 32: 337-346.

Stewart FJ, Fritsen CH (2004) Bacteria-algae relationships in Antarctic sea ice. Antarctic Science 16: 143-156.

Sullivan CW, Palmisano AC (1984) Sea ice microbial communities: Distribution, abundance, and diversity of ice bacteria in McMurdo Sound, Antarctica, in 1980. Applied and Environmental Microbiology 47: 788-795.

Thomas DN, Dieckmann GS (2002) Antarctic sea ice - a habitat for extremophiles. Science 295: 641-644.

Thomas, DN, Kattner G, Engbrodt R, Giannelli V, Kennedy H, Haas C, Dieckmann GS (2001) Dissolved organic matter in Antarctic sea ice. Annals of Glaciology 33: 297-303. 


\section{APPENDIX 1 \\ Methodological information referred to in thesis}

\section{Chapter 3 - Experimental control}

The appropriate incubation period for Antarctic sea ice bacteria with respect to the uptake of $\left[{ }^{3} \mathrm{H}\right]$ leucine was determined empirically by conducting a timecourse experiment. Bacteria derived from the congelation layer (bottom) of annual Antarctic fast-ice were incubated in the dark at $-1.8^{\circ} \mathrm{C}$. Incorporation rates were examined at $30 \mathrm{~min}, 60 \mathrm{~min}, 180 \mathrm{~min}, 240 \mathrm{~min}$ and $300 \mathrm{~min}(\mathrm{n}=3)$ (Figure A1).

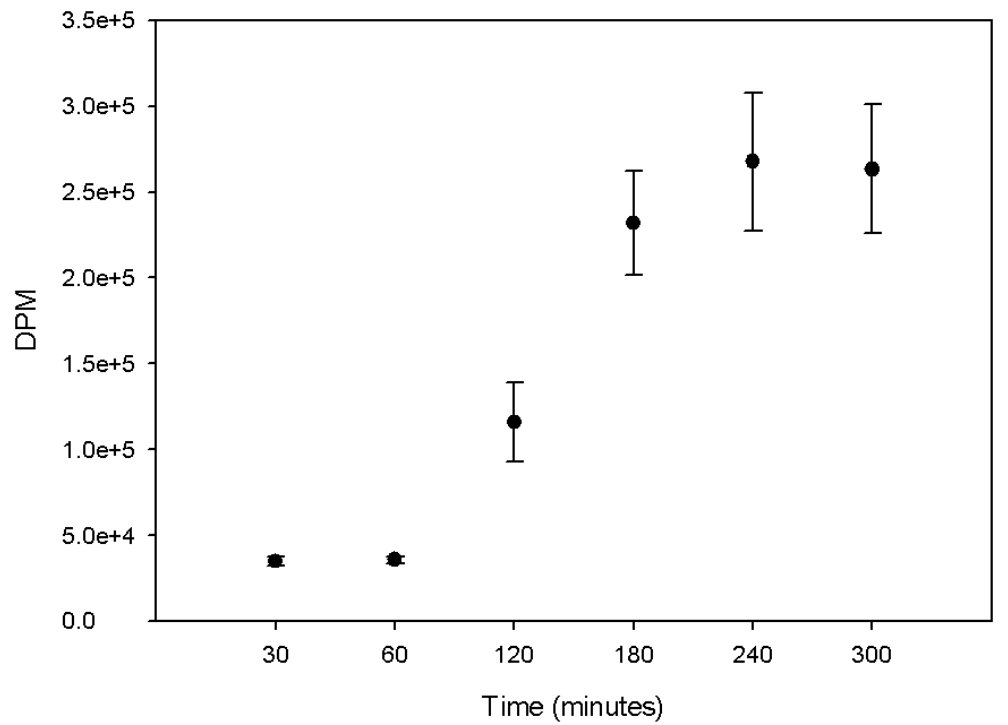

Figure A1: Incorporation rates of $\left[{ }^{3} \mathrm{H}\right]$ leucine in Antarctic sea ice bacteria derived from the bottom of annual fast-ice. DPM refers to disentergrations per minute. 


\section{APPENDIX 2}

\section{Additional research}

During the course of this $\mathrm{PhD}$ research, I have also made a significant contribution to a number of additional studies. I was actively involved in the conceptual design and practical aspects of this work while in Antarctica, and I was later involved in analysing data and writing manuscripts. The following papers are included in this thesis as Appendix 2:

Ryan KG, Cowie ROM, Liggins L, McNaughtan D, Martin A, Davy S (2009) The short-term effect of irradiance on the photosynthetic properties of Antarctic fast-ice microalgal communities. In press: Journal of Phycology.

Ralph P, Ryan KG, Martin A, Fenton G (2007) Melting out causes more photosynthetic stress than freezing in. Journal of Phycology 43: 583-594.

Ryan KG, Hegseth E, Martin A, Davy S, O'Toole R, Ralph P, McMinn A, Thorn C (2006) Abundance and distribution of the microalgal community within sea ice along a latitudinal gradient in the Ross Sea. Antarctic Science 18: 583-594. 


\title{
THE SHORT-TERM EFFECT OF IRRADIANCE ON THE PHOTOSYNTHETIC PROPERTIES OF ANTARCTIC FAST-ICE MICROALGAL COMMUNITIES ${ }^{1}$
}

\author{
Ken G. Ryan, ${ }^{2}$ Rebecca O. M. Cowie, Elizabeth Liggins, Daniel McNaughtan, Andrew Martin, \\ and Simon K. Davy
}

School of Biological Sciences, Victoria University of Wellington, PO Box 600, Wellington 6012, New Zealand

\begin{abstract}
Although sea-ice represents a harsh physicochemical environment with steep gradients in temperature, light, and salinity, diverse microbial communities are present within the ice matrix. We describe here the photosynthetic responses of sea-ice microalgae to varying irradiances. Rapid light curves (RLCs) were generated using pulse amplitude fluorometry and used to derive photosynthetic yield $\left(\Phi_{\mathrm{PSII}}\right)$, photosynthetic efficiency $(\alpha)$, and the irradiance $\left(E_{\mathrm{k}}\right)$ at which relative electron transport rate (rETR) saturates. Surface brine algae from near the surface and bottom-ice algae were exposed to a range of irradiances from 7 to $262 \mu \mathrm{mol}$ photons $\cdot \mathrm{m}^{-2} \cdot \mathbf{s}^{-1}$. In surface brine algae, $\Phi_{\mathrm{PSII}}$ and $\alpha$ remained constant at all irradiances, and rETR $_{\max }$ peaked at $151 \mu \mathrm{mol}$ photons $\cdot \mathrm{m}^{-2} \cdot \mathrm{s}^{-1}$, indicating these algae are well acclimated to the irradiances to which they are normally exposed. In contrast, $\Phi_{\mathrm{PSII}}, \alpha$, and rETR $_{\text {max }}$ in bottom-ice algae reduced when exposed to irradiances $>26 \mu \mathrm{mol}$ photons $\cdot \mathrm{m}^{-2} \cdot \mathrm{s}^{-1}$, indicating a high degree of shade acclimation. In addition, the previous light history had no significant effect on the photosynthetic capacity of bottom-ice algae whether cells were gradually exposed to target irradiances over a $12 \mathrm{~h}$ period or were exposed immediately (light shocked). These findings indicate that bottom-ice algae are photoinhibited in a dose-dependent manner, while surface brine algae tolerate higher irradiances. Our study shows that sea-ice algae are able to adjust to changes in irradiance rapidly, and this ability to acclimate may facilitate survival and subsequent long-term acclimation to the postmelt light regime of the Southern Ocean.
\end{abstract}

Key index words: Antarctic sea ice; $E_{\mathrm{k}}$; PAM fluorometry; photoinhibition; rapid light curves; FTR $_{\text {max }}$; $\alpha ; \Phi_{\text {PSII }}$

Abbreviations: $\alpha$, light-limited photosynthetic efficiency; $\Phi_{\mathrm{PSII}}$, effective quantum yield of PSII; $E_{\mathrm{k}}$, minimum saturating irradiance; $F$, fluorescence yield; $F_{m}^{\prime}, F_{m}$, maximum fluorescence in light and in dark, respectively; PAM, pulse amplitude modulated; rETR $_{\max }$, relative maximum electron transport rate photosynthetic efficiency; RLC, rapid light curve

\footnotetext{
${ }^{1}$ Received 23 November 2008. Accepted 12 June 2009.

${ }^{2}$ Author for correspondence: e-mail ken.ryan@vuw.ac.nz.
}

Diverse microbial communities that are integral to the energy base of the Southern Ocean are present in the brine inclusions and interstices of sea ice (Legendre et al. 1992, Garrison 1991). Although the microalgal component of the sea-ice microbial community can acclimate to the physicochemical gradients that characterize the sea-ice matrix, algal production is strongly influenced by nutrient availability (McMinn et al. 1999, Lizotte and Sullivan 1992), temperature (Arrigo and Sullivan 1992, Ralph et al. 2005), salinity (Arrigo and Sullivan 1992, Ryan et al. 2004, Ralph et al. 2007), and available light (Palmisano et al. 1985).

During sea-ice formation, microbial communities become trapped in brine channels within the ice. In land fast sea ice (sea ice attached to land), the microbial communities that occur close to the ice surface commonly include diatoms and dinoflagellates, where they are frequently exposed to supersaturating irradiances (Robinson et al. 1997). As a result, these surface brine communities have high photosynthetic tolerances to surface irradiance (Ralph et al. 2005). In contrast, bottom-ice algae (predominantly diatoms) are exposed to as little as $0.1 \%$ of the surface irradiance (McMinn et al. 2007), and these algae are highly shade-acclimated (Lizotte and Sullivan 1991). In the Ross Sea fast ice, the greatest sea-ice microbial community biomass usually occurs in the bottom few centimeters (McMinn et al. 2007), where the environmental conditions are relatively stable and favorable for growth. However, surface brine algae and bottomice communities may still encounter a range of environmental conditions. Light conditions can change rapidly due to daily solar fluctuations or storms that may modify the ice-water interface and redistribute snow cover on the surface. Surface brine algae may be confronted with reduced irradiance and bottomice algae with greatly increased irradiance. Is the sea-ice community able to acclimate to these fluctuations, or are they so badly stressed by the sudden change in irradiance that they rapidly die? Their success in surviving within the sea ice and eventually establishing a phytoplankton bloom when the sea ice melts in spring may be determined by their ability to photoacclimate to rapid changes in irradiance.

The ability of the photosynthetic apparatus to acclimate to solar fluctuations in ambient irradiance is crucial for maintaining photosynthesis and 
enabling cell function at both limiting and excessive light levels (Ralph and Gademann 2005). Sea-ice algae may respond to increases or decreases in irradiance within minutes via photoinhibition, or over a longer time period by photoacclimation (Lizotte and Sullivan 1991, Robinson et al. 1997, Han et al. 2000, McMinn et al. 2003, Ryan et al. 2004, Ralph et al. 2005). Photoacclimation requires a change at the physiological and biochemical composition level, whereas photoinhibition occurs mainly at the electron transport chain in PSII (Han et al. 2000). For example, the decrease in chl $a$ concentration in sea-ice microalgae after a 3-4 d exposure to high irradiances and subsequent increase after a similar exposure to lower irradiances (Lizotte and Sullivan 1991) are photoacclimation responses. Photoinhibition is an often reversible reduction in photosynthetic capacity that occurs in plants when exposed to high irradiance (Han et al. 2000) and occurs via the closing down of reaction centers of PSII and a decrease in electron transport rate (ETR). Thus, at high midday irradiances, a shortterm photoinhibitory response was observed in bottom-ice algae from McMurdo Sound (McMinn et al. 2003), although McMinn and Hattori (2006) found no evidence of photoinhibition in a similar community from the Saroma Ko Lagoon, Hokkaido.

Photoinhibition of PSII under normal circumstances is thought of as a photoprotective mechanism rather than damaging and is directly related to chloroplast-encoded protein synthesis, in particular the D1 protein (Anderson et al. 1997). Under normal photosynthesis, photoinactivation of PSII and repair via D1 synthesis occur in parallel, even in low-light conditions. In supersaturating irradiances, the rate of $\mathrm{D} 1$ inactivation exceeds its capability for repair, resulting in an apparent photoinhibition (Lee et al. 2001). The photoinactivation of PSII has been shown to occur in a light dosage manner and is dependent on the number of photons absorbed rather than the rate of photons absorbed (Anderson et al. 1997, Han et al. 2000, Lee et al. 2001).

Few studies have utilized chl fluorescence techniques to measure photosynthetic properties of seaice bottom algae. Kühl et al. (2001) were the first to measure photosynthesis using a pulse-amplitudemodulated (PAM) (Schreiber et al. 1994) chl fluorometer (diving PAM) in bottom-ice algae in Greenland. Most photosynthetic studies have focused on bottom-ice algae perhaps due to their high biomass (McMinn et al. 1999, 2000, 2003, 2007, Ryan et al. 2004, McMinn and Hattori 2006), with only two studies investigating brine microalgal physiology (Ralph et al. 2005, 2007). Surface brine algae may tolerate surface irradiances up to $350 \mu \mathrm{mol}$ photons. $\mathrm{m}^{-2} \cdot \mathrm{s}^{-1}$, whereas bottom communities are highly dark acclimated and may be more easily damaged by increases in irradiance.

In the present study, the photosynthetic response of surface brine and bottom-ice algal communities to changes in irradiance was examined using PAM fluorometry. We applied a range of irradiances either gradually or via light shock to algal isolates to determine whether the previous light history modified the photosynthetic response. We measured changes in effective quantum yield $\left(\Phi_{\mathrm{PSII}}\right)$, relative electron transport rate $\left(\mathrm{rETR}_{\max }\right)$, photosynthetic efficiency $(\alpha)$, and saturation irradiance $\left(E_{\mathrm{k}}\right)$ using the RLC technique (Henley 1993) to (i) determine whether sea-ice algae are able to acclimate to sudden changes in irradiance associated with daily solar fluctuations or storm events and (ii) assess the ability of sea-ice algae to survive these events and contribute to bloom events in the Southern Ocean.

\section{MATERIALS AND METHODS}

Physical parameters. Temperature data loggers (MicroDAQ, Contoocook, NH, USA) were embedded at $20 \mathrm{~cm}$ intervals through the full $2.5 \mathrm{~m}$ thickness of sea ice in the region of Gondwana Station, Terra Nova Bay, Antarctica (164 13 E, $74^{\circ} 38 \mathrm{~S}$ ). PAR sensors were encased in resin and embedded in the ice at depths of $0.5,1.5$, and $2.3 \mathrm{~m}$, and a further sensor was deployed above the ice to obtain surface irradiances.

Surface brine algae. Surface brine algae were extracted from $2.6 \mathrm{~m}$ thick fast ice on 22 November 2006. Three holes were drilled to a depth of $700 \mathrm{~mm}$ using a $150 \mathrm{~mm}$ diameter ice coring drill (Kovaks, Lebanon, NH, USA, Mark V). To prevent exposure to ambient surface irradiance, the holes were covered with black plastic, and brine from the adjacent ice was allowed to drain into the holes over the following $10 \mathrm{~min}$. Approximately $100 \mathrm{~mL}$ of brine was collected from each hole using sterile syringes, transferred to a dark container, and maintained at a temperature of $0^{\circ} \mathrm{C}$ overnight. Four $20 \mathrm{~mL}$ samples were taken from each of the three stock suspensions and allocated to $25 \mathrm{~mL}$ glass vials (12 vials total). All vials were placed in a refrigerated water bath and kept in the dark for $2 \mathrm{~h}$ at $-1.8^{\circ} \mathrm{C}$. One vial from each ice core was used as a dark control $(n=3)$, and the other three were allocated to separate light treatments $(n=3 \times 3=9)$. The ambient irradiance of the two communities was determined directly by measuring irradiance with HOBO PAR sensors (MicroDAQ) embedded in the sea ice at $50 \mathrm{~cm}$ and immediately below the ice, and calculating the $\%$ transmission.

Bottom-ice algae. Core samples of sea ice were taken using the ice coring drill on 26 and 29 November, and 4 and 5 December 2006. Cores were withdrawn from the ice shrouded in a black cloth, and the bottom $400 \mathrm{~mm}$ was transferred to a black plastic bag to avoid light shock to the algae. Samples were collected from three ice cores on each day. There was a 1-2 cm platelet-ice layer on the underside of the ice, and ice algae were concentrated in a firm consolidated region $2 \mathrm{~cm}$ thick above the platelets. The bottom $100 \mathrm{~mm}$ of the ice core containing ice algae was melted in three times the volume of filtered $(0.7 \mu \mathrm{m})$ seawater overnight to avoid salinity shock (Ralph et al. 2007). This method maintained the salinity of the sample at $\sim 31 \%$, which is slightly less than ambient levels. During the melting process, the algae were kept in dark boxes at $-1.8^{\circ} \mathrm{C}$. Other extraction methods, such as direct collection by scuba divers, were not practical at this remote field site.

Once melted, the cells were filtered through a $60 \mu \mathrm{m}$ mesh filter (Madison Filter, Auckland, New Zealand) to remove large chains of cells to obtain a uniform suspension, diluted to a standardized concentration of chl (measured on a Water-PAM fluorometer; Walz Gmbh, Effeltrich, Germany), and homogenized using a battery drill with a plastic stirrer (Ryobi 12W, 
Hong Kong, China). Twelve $25 \mathrm{~mL}$ sample vials of bottom-ice algae were prepared as described above.

PAM fluorometry. PAM fluorometry measures chl $a$ fluorescence, providing a tool to assess the effective quantum yield of photosynthesis of PSII $\left(\Phi_{\text {PSII }}\right)$. Apart from the initial dark incubation, the cells were not dark acclimated before RLCs were performed. A weak measuring light allows fluorescence yield to be monitored without inducing photosynthesis. This minimum fluorescence under light-acclimated conditions is termed $F^{\prime}$ and measures the proportion of closed PSII reaction centers, and it is proportional to the chl concentration. When cells are exposed to a strong saturating actinic light $\left(3,000 \mu \mathrm{mol}\right.$ photons $\left.\cdot \mathrm{m}^{-2} \cdot \mathrm{s}^{-1}\right)$ for $0.8 \mathrm{~s}$, all PSII reaction centers are rapidly closed, and chl fluorescence increases to maximum $\left(F_{\mathrm{m}}^{\prime}\right)$ before it declines back to an equilibrium level. Effective quantum yield $\left(\Phi_{\mathrm{PSII}}\right)$ is defined as: $\left(F_{\mathrm{m}}^{\prime}-F^{\prime}\right) / F_{\mathrm{m}}^{\prime}=$ $\Delta F / F^{\prime}{ }_{\mathrm{m}}$ (Genty et al. 1989). Since this value is a ratio of two fluorescence measures, it is dimensionless.

An RLC was recorded on each sample using the PAM system. Each cuvette was treated with a series of eight increasing actinic light treatments. After each $20 \mathrm{~s}$ period of actinic light, a strong saturating pulse was applied and $\Phi_{\text {PSII }}$ was recorded. The ETR values were calculated by multiplying the $\Phi_{\text {PSII }}$ by the irradiance just applied. Since $\Phi_{\text {PSII }}$ is dimensionless, the ETR value is properly termed relative ETR (rETR). No correction for the proportion of light shared by PSI (often assumed to be 0.5 ) was applied to the rETR, as the relative proportion of PSI and PSII is not known in this system. Similarly, no absorption coefficient (often assumed to be 0.84) was applied as this is unknown also. All RLCs can be described by the parameters rETR $_{\max }$, maximum relative electron transport rate $\left(\mu \mathrm{mol}\right.$ photons $\left.\cdot \mathrm{m}^{-2} \cdot \mathrm{s}^{-1}\right) ; E_{\mathrm{k}}$, the irradiance at the onset of saturation of photosynthesis $(\mu \mathrm{mol}$ photons $\cdot \mathrm{m}^{-2} \cdot \mathrm{s}^{-1}$ ); and $\alpha$, light-limited photosynthetic efficiency; and the initial slope of the RLC, which gives an indication of the efficiency of light utilization. To determine these photosynthetic parameters, rETR data were imported into Sigmaplot v. 8.0 (Systat Software Inc., Chicago, IL, USA), and the curve was fitted with a Marquardt-Levenberg regression algorithm (Platt et al. 1980):

$$
P=P_{\mathrm{s}}\left(1-e^{-\left(\alpha E_{\mathrm{d}} / P_{\mathrm{s}}\right)}\right) e^{-\left(\beta E_{\mathrm{d}} / P_{\mathrm{s}}\right)}
$$

where $P$ is photosynthesis (here rETR), $P_{\mathrm{s}}$ is the maximal potential rETR in the absence of a photoinhibitory response, $\alpha$ is the initial slope of the RLC before the onset of saturation, and $E_{\mathrm{d}}$ is the downwelling irradiance $(400-700 \mathrm{~nm})$. The $\beta$ signifies the slope of the curve after the onset of photoinhibition. To find the $\mathrm{rETR}_{\max }$, the following equation was utilized:

$$
\operatorname{rETR}_{\max }=P_{\mathrm{s}}(\alpha / \alpha+\beta)(\beta / \alpha+\beta)^{\beta / \alpha}
$$

$E_{\mathrm{k}}$ can be described as follows:

$$
E_{\mathrm{k}}=\mathrm{rETR}_{\max } / \alpha
$$

Water bath/PAR illumination source. In the water bath, a box made of black acrylic plastic was separated into 24 individual chambers, each containing $6 \times 5 \mathrm{~mm}$ holes to allow throughput of coolant (20\% clear ethylene glycol in water). Each chamber had an individual clear acrylic lid, to which neutral density filters (Wellington Photographic Supplies, Wellington, New Zealand) could be fitted to modify the light environment within each individual chamber. The lids were interchangeable from chamber to chamber, and this allowed a random allocation of each of six different light levels $(0,7,26,75$, 151, and $262 \mu \mathrm{mol}$ photons $\left.\cdot \mathrm{m}^{-2} \cdot \mathrm{s}^{-1}\right)$. A light bank of 35-50 W quartz halogen lamps (Philips, New Zealand) was suspended over the water bath, and fans were employed to cool the lamp housings. The lamps were arranged to provide a uniform field of light over the water bath incubator.
Experiment 1. Gradually increasing light exposure (ramping): Here we test the response of algae to gradually increasing exposure to the six light levels listed above. All the brine and bottom-ice algae (except the dark controls) were exposed to incremental steps of irradiance for $2 \mathrm{~h}$ each. The brine algae were collected on 26 November 2006, and the experiment was run on 27 November. The dates for the bottom-ice algae run were 29/30 November 2006. Vials were placed in the appropriate chamber sequentially $4 \mathrm{~min}$ apart to allow time for individual RLCs to be performed on each sample $2 \mathrm{~h}$ later. At the end of each light incubation period, the vials were agitated gently, and then a $0.5 \mathrm{~mL}$ subsample was removed from each vial and diluted with $2.5 \mathrm{~mL}$ of $0.7 \mu \mathrm{m}$ filtered seawater. The original sample was immediately returned to the incubator and placed in a new, randomly allocated position where it received the next highest irradiance. Each subsample was placed in a quartz cuvette and inserted into the Water PAM system, and an RLC was generated (see below). The PAM cuvette holder was kept in a cool box along with ice packs to ensure that the subsamples were not temperature shocked prior to taking measurements. When the RLC was completed, the diluted suspension was discarded. At the end of the full $12 \mathrm{~h}$ treatment, the dark control samples were shifted directly to the highest irradiance for a further $2 \mathrm{~h}$.

Experiment 2. Gradually increasing light exposure and maintenance at each step (ramp and hold): This experiment is very similar to Experiment 1 but tests whether the bottom-ice algal response to each irradiance changes with time (experiment dates $4 / 5$ December $)$. Eighteen vials $(6 \times 3$ replicates $)$ were exposed to the six consecutive light levels as described above for Experiment 1, but at each transfer of vials from one irradiance to the next, three vials were held back and maintained at that prior irradiance for the rest of the treatment period.

Experiment 3. Sudden irradiance increase (light shock), then maintenance at each step: This experiment tests whether prior exposure to lower light levels as achieved in the previous experiments has any influence on photosynthesis (experiment dates 5/6 December). At the end of the dark acclimation, three vials were transferred directly to each of the six irradiances described above and held there for a further $4 \mathrm{~h}$.

Statistical analyses. Differences in brine and bottom-ice algae with respect to change in irradiance treatments for effective quantum yield $\left(\Phi_{\mathrm{PSII}}\right), \mathrm{rETR}_{\max }, \alpha$, and $E_{\mathrm{k}}$ were measured using the Pearson's correlation coefficient with the test statistic $(r)$ at 0.05 . Normality of data was assessed using the Anderson-Darling test. Mean values were compared using a one-way analysis of variance (ANOVA, test statistic $F$ ) in the form of a generalized linear model (Quinn and Keough 2002) with subsequent Tukey's pair-wise comparisons. When normality was not achieved after transformation, mean values were compared using a Kruskal-Wallis $(\mathrm{K}-\mathrm{W})$ test (test statistic $H$ ) with subsequent Dunn's procedure for pair-wise comparisons. Individual differences between brine and bottom algae at a particular irradiance were compared using a $t$-test (test statistic $t$ ).

\section{RESULTS}

The samples were collected from a region of snow-free sea ice during early summer when air temperatures fluctuated between +8 and $-12^{\circ} \mathrm{C}$. PAR levels varied between 100 and $1,200 \mu \mathrm{mol}$ photons $\cdot \mathrm{m}^{-2} \cdot \mathrm{s}^{-1}$ from midnight to midday. Ice temperatures were $-7^{\circ} \mathrm{C}$ at $0.7 \mathrm{~m}$ depth (surface brine algae collection) and $-1.8^{\circ} \mathrm{C}$ at the ice-water interface (bottom-ice algae collection). The midday light levels measured in the ice during collections 
were $\sim 80 \mu \mathrm{mol}$ photons $\cdot \mathrm{m}^{-2} \cdot \mathrm{s}^{-1}$ at $0.5 \mathrm{~m}$ depth (surface brine algae) and $<1 \mu \mathrm{mol}$ photons $\cdot \mathrm{m}^{-2} \cdot \mathrm{s}^{-1}$ at $2.3 \mathrm{~m}$ depth, just above the bottom-ice algal layer.

Experiment 1. Light-ramping treatment: Both the surface brine algae and bottom-ice algae showed a photosynthetic recovery during the initial $2 \mathrm{~h}$ of dark incubation. $\Phi_{\text {PSII }}$ for the surface brine algae recovered to 0.29 from 0.22 (Fig. 1a) and in bottom-ice algae to 0.29 from 0.23 (Fig. 1b). Surface brine algae involved in the light-ramping experiment showed a significantly higher $\Phi_{\text {PSII }}$ from the brine ice algae maintained in the dark (K-W, $H_{7}=37.53, P<0.001$, Fig. 1a). In contrast, bottomice algae involved in light ramping had a significantly lower $\Phi_{\mathrm{PSII}}$ than those incubated in the dark (K-W, $H_{7}=60.17, P<0.001$, Fig. 1b). Although, $\Phi_{\text {PSII }}$ increased with increased exposure to light in the surface brine algae (Pearson's, $r_{21}=0.585$, $P<0.001), \Phi_{\mathrm{PSII}}$ reached a plateau at $0.33 \pm 0.01$. The opposite was seen in bottom-ice algae where $\Phi_{\text {PSII }}$ decreased with exposure to irradiances $>26 \mu \mathrm{mol}$ photons $\cdot \mathrm{m}^{-2} \cdot \mathrm{s}^{-1}$ (Dunn's pair-wise comparisons, $P<0.01$ for all comparisons). The $\Phi_{\mathrm{PSII}}$ of both brine and bottom-ice algae in the dark incubations remained constant over time, with bottomice algae having a slightly higher $\Phi_{\text {PSII }}$ than that of the surface brine algae (surface brine algae, $0.29 \pm 0.11$; bottom-ice algae, $0.32 \pm 0.08$ ). When suddenly exposed to the maximum irradiance of $262 \mu \mathrm{mol}$ photons $\cdot \mathrm{m}^{-2} \cdot \mathrm{s}^{-1}$ after $12 \mathrm{~h}$ of darkness, the dark-incubated surface brine algae showed no significant change in $\Phi_{\text {PSII }}$ ( $t$-test, $\left.t_{5}=0.30, P=0.773\right)$, nor was $\Phi_{\mathrm{PSII}}$ significantly different from that for surface brine algae exposed to the incremental series of irradiances ( $t$-test, $\left.t_{6}=1.15, \quad P=0.294\right)$. In contrast, when suddenly exposed to an irradiance of $262 \mu \mathrm{mol}$ photons $\cdot \mathrm{m}^{-2} \cdot \mathrm{s}^{-1}$ after $12 \mathrm{~h}$ of darkness, bottomice algae showed a significant drop in $\Phi_{\text {PSII }}$ to $0.07 \pm 0.01 \quad\left(t\right.$-test $\left., t_{2}=18.56, P<0.001\right)$. This new level was not significantly different from that in algae exposed gradually to increasing irradiance over $12-14 \mathrm{~h}$ ( $t$-test, $\left.t_{4}=0.26, P=0.806\right)$.

Photosynthetic efficiency $(\alpha)$ showed a similar trend to $\Phi_{\text {PSII. }}$ The light-exposed surface brine algae had an increase in $\alpha$ with increased irradiance (Pearson's, $r_{64}=0.588, P<0.0011$, Fig. 1c), and bottom-ice algae showed a decrease in $\alpha$ with increasing irradiance (Pearson's, $r_{67}=0.637, \quad P<0.001$, Fig. 1d). The cells held in the dark maintained a constant $\alpha$ over time in both the brine (Pearson's, $r_{16}=0.319, P=0.138$, Fig. 1c) and bottom-ice algae (Pearson's, $r_{16}=0.359, P=0.143$ Fig. 1d). When these algal cells were suddenly exposed to an irradiance of $262 \mu \mathrm{E}, \alpha$ values were not dissimilar to those of algae exposed to steadily increasing irradiance (surface brine algae $t$-test, $t_{6}=0.64, \quad P=0.547$; bottom-ice algae $t$-test, $t_{1}=1.06, P=0.329$, Fig. 1 , c and $\mathrm{d}$ ).
rETR $_{\max }$ was higher for the surface brine algae with values ranging from 24.0 to $68.3 \mu \mathrm{mol}$ photons $\cdot \mathrm{m}^{-2} \cdot \mathrm{s}^{-1}$. In comparison, the $\mathrm{rETR}_{\max }$ of bottomice algae did not increase above $11.3 \pm 2.3 \mu \mathrm{mol}$ photons $\cdot \mathrm{m}^{-2} \cdot \mathrm{s}^{-1}$. Following the same trends, surface brine algae had a significant increase in rETR $_{\max }$ when exposed to increasing irradiance (Pearson's, $r_{64}=0.642, P=0.001$ ), and bottom-ice algae had a significant decrease in activity (Pearson's, $\left.r_{22}=-0.472, P=0.020\right)$. Brine and bottom-ice algae in the dark incubations maintained a constant $\mathrm{rETR}_{\text {max }}$; however, surface brine algae maintained a higher ETR $_{\max }(28.68 \pm 2.64$, Fig. 1e $)$ than did the bottom-ice algae (7.17 \pm 0.62 , Fig. 1f). Brine and bottom-ice algae again showed contrasting changes in $\mathrm{rETR}_{\max }$ when suddenly exposed to high irradiance. The $\mathrm{rETR}_{\max }$ of surface brine algae significantly increased when moved from darkness to high light (ANOVA, $F_{7,15}=3.41, P=0.022$ ), whereas the bottom-ice algae showed a significant decrease in rETR $_{\max }\left(t\right.$-test, $\left.t_{2}=4.91, P=0.039\right)$. In both cases, when the dark-treated cells were moved into high light, $\mathrm{rETR}_{\max }$ values were not significantly different from the $\mathrm{rETR}_{\max }$ values recorded from the lightramping algae.

Maximum saturating irradiance $\left(E_{\mathrm{k}}\right)$ was higher in surface brine algae in comparison to bottom-ice algae. When exposed to the light-ramping experiment, surface brine algae had maximum $E_{\mathrm{k}}$ of $219 \pm 17.2 \mu \mathrm{mol}$ photons $\cdot \mathrm{m}^{-2} \cdot \mathrm{s}^{-1}$ at exposure to $262 \mu \mathrm{E}$ in comparison to the maximum $E_{\mathrm{k}}$ in bottom-ice algae of $58.03 \pm 7.7 \mu \mathrm{mol}$ photons $\cdot \mathrm{m}^{-2} \cdot \mathrm{s}^{-1}$ at $151 \mu \mathrm{mol}$ photons $\cdot \mathrm{m}^{-2} \cdot \mathrm{s}^{-1}$. Surface brine algae incubated in increasing light regimes had a significantly higher $E_{\mathrm{k}}$ in comparison to algae in the dark incubations (ANOVA, $F_{1,7}=11.47, P<0.001$, Fig. $1 \mathrm{~g}$ ) and significantly increased as the incubation irradiance increased (Pearson's, $r_{64}=0.684$, $P<0.001) . \quad E_{\mathrm{k}}$ also significantly increased in bottom-ice algae as the incubation irradiance steadily increased $\left(r_{22}=0.660, P<0.001\right.$, respectively). Algae incubated in darkness maintained a constant $E_{\mathrm{k}}$ (surface brine algae, $94.05 \pm 7.07 \mu \mathrm{E}$, Fig. 1g), (bottom-ice algae, $23.54 \pm 4.67 \mu \mathrm{mol}$ photons $\cdot \mathrm{m}^{-2} \cdot \mathrm{s}^{-1}$, Fig. 1h). There was a significant increase in $E_{\mathrm{k}}$ when dark-treated surface brine algae were suddenly exposed to high light $\left(t\right.$-test, $\left.t_{2}=4.76, P=0.041\right)$. This trend was similar for bottom-ice algae; however, the increase in $E_{\mathrm{k}}$ was not significant.

Experiment 2. Ramp-and-hold treatment: In this experiment, bottom-ice algae were exposed to progressively higher irradiances exactly as in Experiment 1, but this time, three replicates were maintained at each prior light increment (Fig. 2). As before, $\Phi_{\text {PSII }}$ decreased in a dose-dependent manner (Tukey's pair-wise comparisons, $P<0.001$, Fig. 2a), where the curve exactly matched the $\Phi_{\text {PSII }}$ curve shown in Figure 1b. The bottom-ice algal cells maintained at each irradiance had a stable $\Phi_{\mathrm{PSII}}$ at 

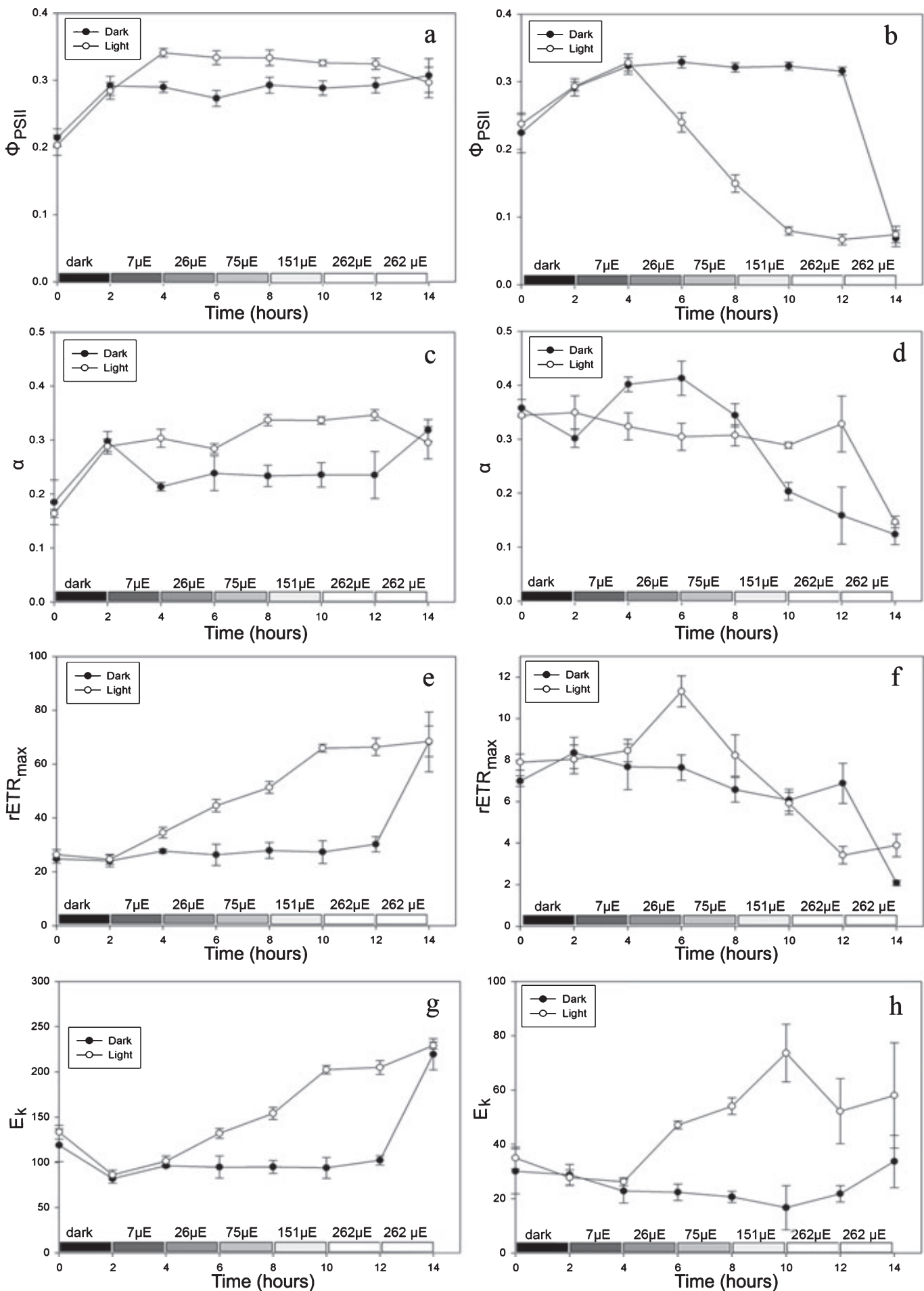

Fig. 1. Changes in measures of photosynthetic activity in surface brine algae (left column) and bottom-ice algae (right column) when exposed to increasing irradiance. After $12 \mathrm{~h}$, the samples from the dark incubation were transferred to the highest irradiance treatment for an additional $2 \mathrm{~h}$. (a and b) Effective photosynthetic yield $\left(\Phi_{\mathrm{PSII}}\right)$. (c and d) Photosynthetic efficiency $(\alpha)$. (e and f) Relative electron transport rate $\left(\mathrm{rETR}_{\max }\right)$. ( $\mathrm{g}$ and $\left.\mathrm{h}\right)$ Minimum saturating irradiance $\left(E_{\mathrm{k}}\right)$. Units: $\mu$ mol photons $\cdot \mathrm{m}^{-2} \cdot \mathrm{s}^{-1}$. Data are means $\pm 1 \mathrm{SE}$.

each particular light level for the duration of the measurements (Tukey's pair-wise comparisons, $P=n s$ for all comparisons). The $\mathrm{rETR}_{\max }$ and $\alpha$ showed a similar pattern, where there was a significant decrease in activity $>26 \mu \mathrm{mol}$ photons $\cdot \mathrm{m}^{-2} \cdot \mathrm{s}^{-1}$ treatment (Tukey's pair-wise comparisons, $P<0.001$, Fig. 2b) followed by maintenance of activity at each level (Tukey's pair-wise comparisons, 

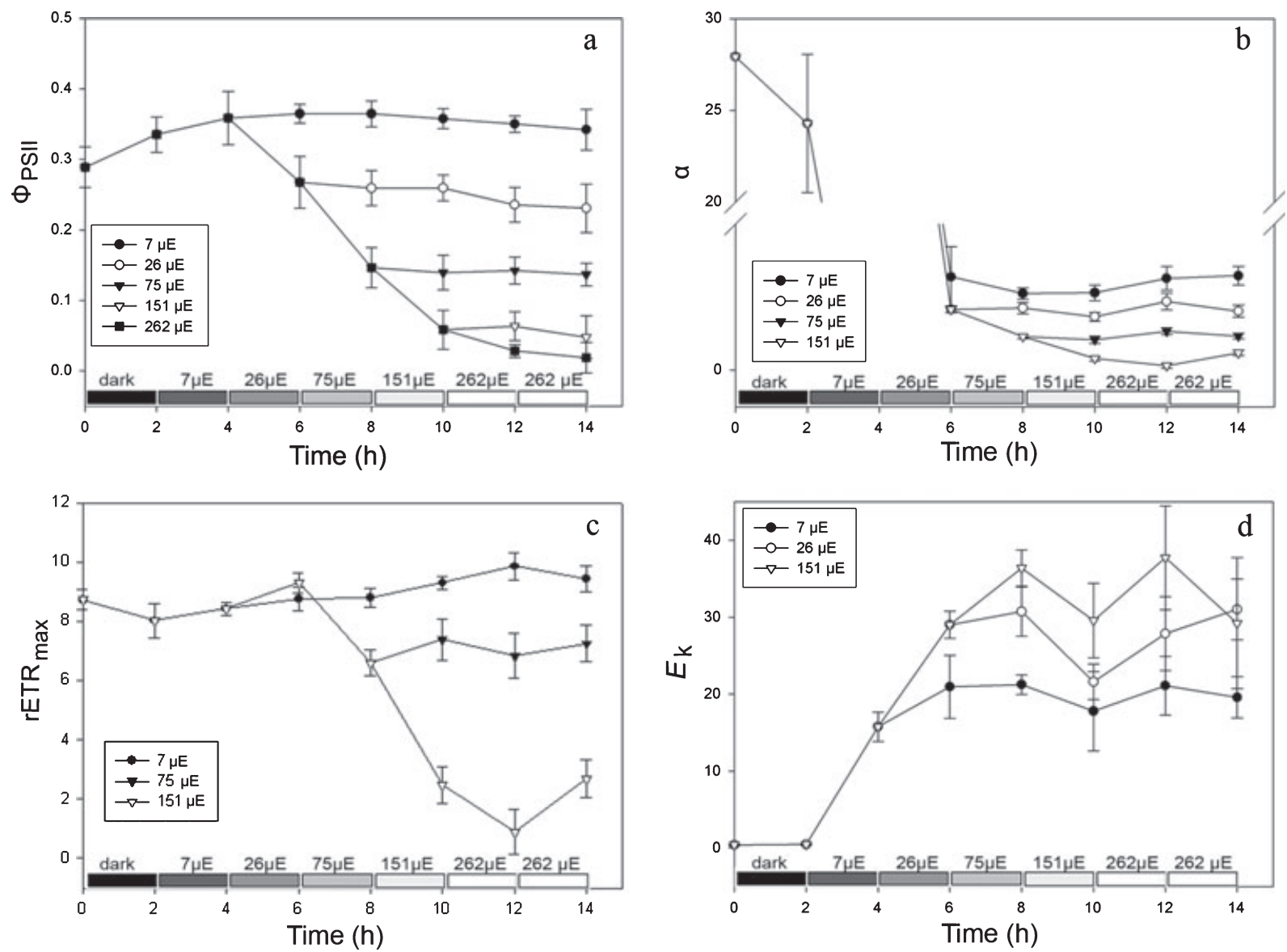

FIG. 2. Changes in photosynthetic activity of bottom-ice algae when exposed to increments of increased irradiance ( $\mu$ mol photons $\left.\cdot \mathrm{m}^{-2} \cdot \mathrm{s}^{-1}, \mu \mathrm{E}\right)$. (a) Effective photosynthetic yield $\left(\Phi_{\mathrm{PSI}}\right)$. (b) Photosynthetic efficiency $(\alpha)$. (c) Relative maximum electron transport rate $\left(\mathrm{rETR}_{\max }\right)$. (d) Minimum saturating irradiance $\left(E_{\mathrm{k}}\right)$. At each irradiance level, three bottom-ice algae samples were maintained at that constant irradiance for the remainder of the experiment. Data are means $\pm 1 \mathrm{SE}$.

$P=n s)$. When bottom-ice algae were exposed to an irradiance of $7 \mu \mathrm{mol}$ photons $\cdot \mathrm{m}^{-2} \cdot \mathrm{s}^{-1}, \mathrm{rETR}_{\max }$ was maintained at 8.9 (Fig. 2c), similar to the dark control cells in the previous experiment (Fig. 1f). Algae left at 26 and $262 \mu \mathrm{mol}$ photons $\cdot \mathrm{m}^{-2} \cdot \mathrm{s}^{-1}$ had $\mathrm{rETR}_{\max }$ values that were not significantly different from those of algae maintained at 75 and 151, respectively, and are therefore not shown. $E_{\mathrm{k}}$ showed a similar trend to the light-ramping experiment (Fig. 1h) where activity increased with increasing irradiance; however, these trends were not significant (Tukey's pair-wise comparisons, $P=n s$, Fig. 2d).

Experiment 3. Light-shock treatment: After $2 \mathrm{~h}$ of incubation in the dark, bottom-ice algal cells were light shocked to the same irradiances used in the previous two experiments. $\Phi_{\text {PSII }}$ rapidly declined to levels similar to those shown in Figures $1 \mathrm{~b}$ and $2 \mathrm{a}$ at the same irradiances (Tukey's pair-wise comparisons, $P<0.001$ for all comparisons, Fig. 3). Maintenance of $\Phi_{\text {PSII }}$ at the same level occurred in the subsequent $3 \mathrm{~h}$ culture (Tukey's pair-wise comparisons, $P=n s)$. There were no trends detected in the other photosynthetic parameters.

\section{DISCUSSION}

Brine and bottom-ice algae are two photosynthetically and taxonomically distinct communities in land fast sea ice (McMinn et al. 2003, Ralph et al. $2005)$. In these experiments, $\Phi_{\mathrm{PSII}}$ in both darkincubated brine and bottom-ice algae was lower, at $\sim 0.3$, than we have observed in algae from other locations in the Ross Sea (see McMinn et al. 2003, Ralph et al. 2005). In other studies in eastern Antarctica, Ryan et al. (2004) found a $\Phi_{\text {PSII }}$ of 0.34 in bottom-ice algae, which is comparable to the results of the present study. Bottom-ice algae were prescreened for large-chain diatoms to gain a uniform suspension of cells and allow the different treatments to be comparable. This prescreening might perhaps explain the reduced $\Phi_{\text {PSII. }}$ However, $\Phi_{\text {PSII }}$ was also low in the surface brine algae, which did not undergo prescreening. Considerable effort was spent trying to improve isolation and incubation conditions in the present study. For example, the bottom-ice algae were carefully melted out from the ice overnight (in the dark) to minimize light shock and in excess filtered seawater to minimize salinity 


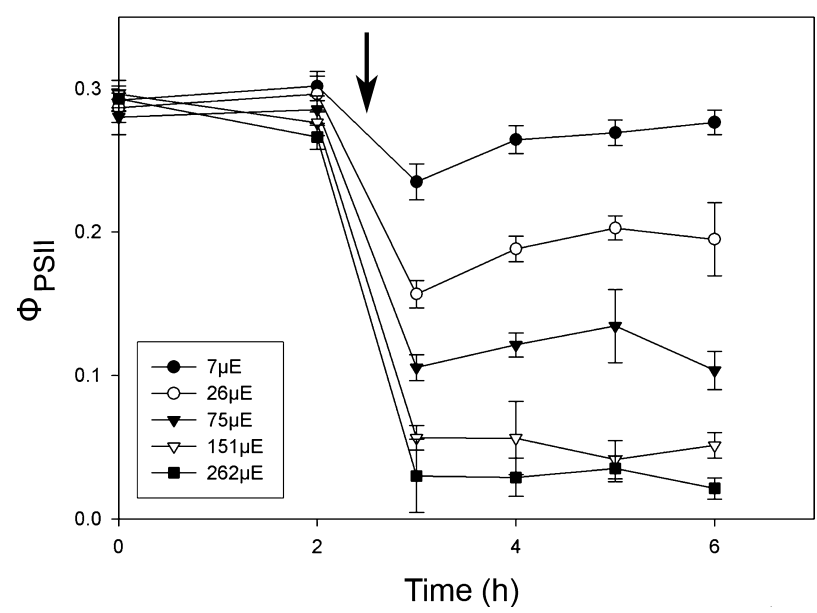

FIG. 3. Changes in effective photosynthetic yield $\left(\Phi_{\mathrm{PSII}}\right)$ of bottom-ice algae. Algae were incubated in the dark for $2 \mathrm{~h}$, then light shocked with a particular irradiance $\left(\mu \mathrm{mol}\right.$ photons $\left.\cdot \mathrm{m}^{-2} \cdot \mathrm{s}^{-1}, \mu \mathrm{E}\right)$ level (arrow). Data are means $\pm 1 \mathrm{SE}$.

shock (final salinity $\sim 31 \%$ compared to ambient seawater salinity of $35 \%$ o). Ralph et al. (2007) have noted that low salinities during melting of $22 \%$ reduce $\Phi_{\mathrm{PSII}}$, but when maintained close to ambient salinities, physiological damage is minimized. We believe that the $\Phi_{\text {PSII }}$ of 0.3 reflects the state of health of the algae at this location at this time. It should be noted that $\Phi_{\mathrm{PSII}}$ in marine phytoplankton is usually lower than that for land plants and is often lower than that found in seagrasses (Ralph and Gademann 2005).

The bottom-ice community in this study was dominated by Berkelya adeliensis, whereas the other studies were dominated by Nitzschia stellata (Ralph et al. 2005) or Fragillariopsis curta (McMinn et al. 2003), which could perhaps explain these discrepancies in $\Phi_{\text {PSII }}$. The surface brine community was composed predominantly of an unidentified dinoflagellate (possibly Polarella sp.).

The bottom-ice algae in this study were collected from $2.6 \mathrm{~m}$ thick annual ice, and the under-ice ambient irradiance was $<1 \mu \mathrm{mol}$ photons $\cdot \mathrm{m}^{-2} \cdot \mathrm{s}^{-1}$. Melted samples of these algae were exposed to gradually increasing irradiances and showed a typical response for highly shadeacclimated photosynthetic organisms (Fig. 1b). The $\Phi_{\mathrm{PSII}}$ initially rose, but then photoinhibition was initiated at irradiances $>7 \mu \mathrm{mol}$ photons $\cdot \mathrm{m}^{-2} \cdot \mathrm{s}^{-1}$. As the exposure to light was increased gradually beyond $7 \mu \mathrm{mol}$ photons $\cdot \mathrm{m}^{-2} \cdot \mathrm{s}^{-1}$ over a $12 \mathrm{~h}$ period, $\Phi_{\text {PSII }}$ declined in a dose-dependent manner. At irradiances $>151 \mu \mathrm{mol}$ photons $\cdot \mathrm{m}^{-2} \cdot \mathrm{s}^{-1}, \Phi_{\text {PSII }}$ in bottom-ice algae was as low as 0.01 . When other bottom-ice algae samples, which had been held in the dark for the same period, were suddenly exposed to high irradiance, they showed a rapid photoinhibitory response (Fig. 1b). The $\Phi_{\text {PSII }}$ dropped to the same value as for the samples of bottom-ice algae that had been gradually exposed to light at this level. In addition, $\alpha$ decreased to match the values seen in lighttreated cells, while rETR $_{\max }$ did not change through the course of the experiment at any treatment. This finding indicates that previous light history had no influence on the short-term response of bottom-ice algae to increased numbers of light photons.

The surface brine algae in this study were collected $\sim 0.7 \mathrm{~m}$ from the surface. At this depth in the ice, the irradiance at midday on a clear day reached $\sim 80 \mu \mathrm{mol}$ photons $\cdot \mathrm{m}^{-2} \cdot \mathrm{s}^{-1}$, and these algae are therefore acclimated to much higher light intensities than the algae at the bottom of the ice. In our incubation experiments, the $\Phi_{\mathrm{PSI}}$ increased initially with exposure to light and maintained this high level above that of dark-treated cells for the duration of the experiment. There was no significant decrease in photosynthetic capacity even at the highest irradiance of $262 \mu \mathrm{mol}$ photons $\cdot \mathrm{m}^{-2} \cdot \mathrm{s}^{-1}$, suggesting no photoinhibition or damage to the photosynthetic apparatus. These values are comparable to those of Ralph et al. (2005) where surface brine algae from a Cape Hallett also demonstrated extensive photosynthetic activity over a range of irradiances. They observed surface brine algae to have phototolerance up to $370 \mu \mathrm{mol}$ photons $\cdot \mathrm{m}^{-2} \cdot \mathrm{s}^{-1}$, with no evidence of photoinhibition. As for the bottom-ice algae, the previous light history of surface brine cells had no effect on the photosynthetic capacity. On exposure to $262 \mu \mathrm{mol}$ photons $\cdot \mathrm{m}^{-2} \cdot \mathrm{s}^{-1}$, the dark-control and the light-exposed cells had the same photosynthetic activity, regardless of their previous light history. In addition, $\alpha, \mathrm{rETR}_{\max }$, and $E_{\mathrm{k}}$ all increased in the brine dark-control cells to an activity level similar to that of the light-exposed cells.

Shade-acclimated plants have higher $\alpha$, indicating that they can utilize lower irradiances more effectively (Dubinsky et al. 1986, Kirst and Wiencke 1995). When comparing dark-incubated brine and bottom-ice algae in the light-ramping experiment, $\alpha$ was higher in the bottom-ice algae $(0.32 \pm 0.02)$ than surface brine algae $(0.23 \pm 0.03)$. When observing algal cells incubated in increasing irradiances, $\alpha$ reached a maximum of 0.41 in bottom-ice algae when exposed to $26 \mu \mathrm{mol}$ photons $\cdot \mathrm{m}^{-2} \cdot \mathrm{s}^{-1}$, which declined as irradiance increased $>75 \mu \mathrm{mol}$ photons $\cdot \mathrm{m}^{-2} \cdot \mathrm{s}^{-1}$, indicating the effectiveness of low-light utilization in bottom-ice algal communities. In the high-light-acclimated surface brine algae, $\alpha$ increased with irradiance and reached a maximum of 0.35 at $151 \mu \mathrm{mol}$ photons $\cdot \mathrm{m}^{-2} \cdot \mathrm{s}^{-1}$, again showing algal communities are well acclimatized to their ambient light environment.

Surface brine algae had an $\mathrm{rETR}_{\max }$ of between 21 and $68 \mu \mathrm{mol}$ photons $\cdot \mathrm{m}^{-2} \cdot \mathrm{s}^{-1}$. High $\mathrm{rETR}_{\max }$ values are typical of algae exposed to high irradiance, but our values were higher than those found by Ralph et al. (2005), where $\mathrm{rETR}_{\max }$ was $\sim 18 \mu \mathrm{mol}$ photons $\cdot \mathrm{m}^{-2} \cdot \mathrm{s}^{-1}$. In contrast, bottomice algae in our study only reached an $\mathrm{rETR}_{\max }$ of 
$11 \mu \mathrm{mol}$ photons $\cdot \mathrm{m}^{-2} \cdot \mathrm{s}^{-1}$, which is consistent with that found in shade-acclimated algae in other studies (McMinn et al. 1999). McMinn et al. (2003) found in situ rETR max $_{\text {in }}$ bottom-ice algae to be at a maximum value of $11 \mu \mathrm{mol}$ photons $\cdot \mathrm{m}^{-2} \cdot \mathrm{s}^{-1}$ at midday at in situ irradiances of $<5 \mu \mathrm{mol}$ photons $\cdot \mathrm{m}^{-2} \cdot \mathrm{s}^{-1}$. Maximum $\mathrm{rETR}_{\max }$ occurred at irradiances of 151 and $26 \mu \mathrm{mol}$ photons $\cdot \mathrm{m}^{-2} \cdot \mathrm{s}^{-1}$ in brine and bottom algae, respectively, further confirming their photosynthetic acclimatization to their environment (Cota 1985).

Irradiance at the onset of saturation $\left(E_{\mathrm{k}}\right)$ is often utilized to quantify shade acclimation (Kirst and Wiencke 1995, Ralph and Gademann 2005). E $E_{\mathrm{k}}$ was much higher in surface brine algae with values of 80 to $219 \mu \mathrm{mol}$ photons $\cdot \mathrm{m}^{-2} \cdot \mathrm{s}^{-1}$ in comparison to bottom algae (24 to $58 \mu \mathrm{mol}$ photons $\cdot \mathrm{m}^{-2} \cdot \mathrm{s}^{-1}$ ), illustrating their respective light environments. Similar values were recorded in low-light- and high-lightacclimated seagrass leaves (Ralph and Gademann 2005). McMinn et al. (2007) found $E_{\mathrm{k}}$ of similar values for bottom-ice algae from 21 to $69 \mu \mathrm{mol}$ photons $\cdot \mathrm{m}^{-2} \cdot \mathrm{s}^{-1}$. In this study, $E_{\mathrm{k}}$ increased with light intensity in both the brine and the bottom-ice algae. A similar trend was also observed in bottom-ice algae in situ by McMinn et al. (2003) where $E_{\mathrm{k}}$ varied between 2.1 and $18 \mu \mathrm{mol}$ photons $\cdot \mathrm{m}^{-2} \cdot \mathrm{s}^{-1}$ with increasing ambient irradiance.

The response of brine and bottom algae darktreated cells to a sudden change in light observed above suggests that the previous light history of the cells did not affect the short-term response to new light levels. We tested this light history response with two further experiments. First, bottom-ice algae were exposed to increased irradiance, but some samples were left behind and maintained at the same irradiance (ramp and hold). Bottom-ice algae showed increased photoinhibition as irradiance level increased with a response curve that is remarkably similar to that in the previous experiment. In addition, the $\Phi_{\mathrm{PSII}}$ of cells "left behind" was maintained at a constant steady-state value for that irradiance. In the light-shock experiment, bottom-ice algae were maintained in the dark and then directly shifted to the five target irradiances. The same steady-state values of $\Phi_{\text {PSII }}$ as in the previous two experiments were recorded at each irradiance. These observations from all three experiments strongly support the conclusion of Anderson et al. (1997) who demonstrated in pea plants that the rate of decline of PSII function is related to the number of photons absorbed rather than the rate of photon delivery and concluded that loss of PSII happens in a light dosage-dependent manner. In their experiments, the number of functional PSII centers in pea leaves declined with increasing photon exposure, where there was always reciprocity between the irradiance and the time of exposure. The law of reciprocity states that an equal amount of photoinactivation is induced by an equal dose of photon exposure and holds in the presence of a D1 inhibitor (Anderson et al. 1997, Han et al. 2000, Lee et al. 2001). However, when D1 protein is present, the decline of active PSIIs stabilizes, and there is no further net loss of PSIIs with photon exposure (Lee et al. 2001). D1 degradation and turnover are highly regulated in high-light-acclimated plants, which, like surface brine algae, have a higher photosynthetic tolerance to high irradiance than their shade-acclimated counterparts. Bottom-ice algae, like shade-acclimated plants (Aro et al. 1993, Anderson et al. 1997), will perhaps have a reduced capacity for D1 regulation and show a lowered ability to repair PSII and will perhaps adhere more to the reciprocity laws. When both photoinactivation and repair of PSII occur, a steady state is reached (Tyystjärvi et al. 1992). Bottom-ice algae in the lower irradiance treatment showed a higher steadystate fraction of functional PSIIs than those exposed to higher irradiance. The maintenance of photosynthetic parameters in bottom-ice algae at a near steady state in response to the ramp-and-hold experiment suggested a balance between photoinactivation of PSIIs and the rate of D1 protein turnover.

There was no significant difference between the 151 and $262 \mu \mathrm{mol}$ photons $\cdot \mathrm{m}^{-2} \cdot \mathrm{s}^{-1}$ light treatments in the bottom-ice algal photosynthetic parameters. Although these parameters decreased with these high-irradiance treatments, bottom-ice algae still produced some photosynthetic activity. A residual amount of functional PSIIs must be able to survive at high irradiances and perhaps are photoprotected in some way. Photoinactivated PSII complexes have been found to accumulate in stacked granal domains and photoprotect the function of neighbors (Aro et al. 1993, Lee et al. 2001). As well as photoprotection from the photoinactivated PSII complexes, shade-acclimated algal cells have additional mechanisms that protect them from shortterm photon exposure. Xanthophyll cycling and cyclic electron flow around the PSII complex (Robinson et al. 1997) and chloroplast intracellular movement for self-shading (Lizotte and Sullivan 1991) are photoprotective responses seen by algae in response to high irradiance.

Sea-ice algae species composition is a subset of that occurring in the water column (Lizotte and Sullivan 1991), and it is likely that these species are part of the phytoplankton seasonally and become incorporated into the sea ice during freezing (Rozanska et al. 2008). Some microalgal species have been collected in both sea ice and the water column, which can be explained by cyclic entrapment in sea ice and subsequent melting of the sea ice in spring (Garrison et al. 1983). Vertical mixing of phytoplankton in the water column also causes changes in irradiance exposure (Falkowski 1984), and therefore, sea-ice algae must have a broad scope for light acclimation. Surface brine algae appear to have photosynthetic 
tolerance and regulation of PSII repair over a wider range of irradiances. In bottom-ice algae, photoinhibition occurs in a dose-dependent manner, and although turnover rate of the D1 protein may be slower than that in the surface brine algae, photosynthesis is still maintained. A residual number of active PSIIs survive at high irradiances, which must be extremely important for the survival of the algae. The present study did not investigate long-term photosynthetic responses to increased irradiance; however, it has been suggested that acclimation does occur over days to weeks (Prezelin and Matlick 1980, Palmisano et al. 1985). Brine and bottom algae are able to survive initial rapid changes in irradiance, such as those that may occur during storm events or with daily solar fluctuations. Brine algae may contribute to sea-ice production even when irradiance is low and snow and ice cover may be thick. When exposed to less rapid changes in irradiance due to melting at the ice, or annual light fluctuations, it is likely that the short-term photosynthetic responses of sea-ice algae will help them survive until they can photoacclimate to their new environment.

We are grateful to the Latitudinal Gradient Project, Antarctica NZ, and especially Brian Staite and Shulamit Gordon for logistic support. The authors thank the New Zealand Foundation for Research Science and Technology contract no. VICX0706 and Victoria University of Wellington for URF grant no. 26252.

Anderson, J. M., Park, Y. I. \& Chow, W. S. 1997. Photoinactivation and photoprotection of photosystem II in nature. Physiol. Plant. 100:214-23.

Aro, E., McCaffery, S. \& Anderson, J. M. 1993. Photoinhibition and D1 protein degradation in peas acclimated to different growth irradiances. Plant Physiol. 103:835-43.

Arrigo, K. R. \& Sullivan, C. W. 1992. The influence of salinity and temperature covariation on the photophysiological characteristics of Antarctic sea ice microalgae. J. Phycol. 28:746-56.

Cota, G. F. 1985. Photoadaptation of high Arctic ice algae. Nature 315:219-22.

Dubinsky, Z., Falkowski, P. G. \& Wyman, K. 1986. Light harvesting and utilisation by phytoplankton. Plant Cell Physiol. 27:1335-49.

Falkowski, P. G. 1984. Physiological responses of phytoplankton to natural light regimes. J. Plankton Res. 6:295-307.

Garrison, D. L. 1991. Antarctic sea-ice biota. Am. Zool. 31:17-33.

Garrison, D. L., Ackley, S. F. \& Buck, D. L. 1983. A physical mechanism for establishing algal populations in frazil ice. Nature 306:363-5.

Genty, B., Briantais, J. M. \& Baker, N. R. 1989. The relationship between the quantum yield of photosynthetic electron transport and quenching of chlorophyll fluorescence. Biochim. Biophys. Acta 990:87-92.

Han, B. P., Virtanen, M., Koponen, J. \& Straskraba, M. 2000. Effect of photoinhibition on algal photosynthesis: a dynamic model. J. Plankton Res. 22:865-85.

Henley, W. J. 1993. Measurement and interpretation of photosynthetic light response curves in algae in the context of photoinhibition and diel changes. J. Phycol. 29:729-39.

Kirst, G. O. \& Wiencke, C. 1995. Ecophysiology of polar algae. J. Phycol. 31:181-99.

Kühl, M., Glud, R. N., Borum, J., Roberts, R. \& Rysgaard, S. 2001. Photosynthetic performance of surface-associated algae below sea ice as measured with a pulse-amplitude-modulated (PAM) fluorometer and $\mathrm{O}_{2}$ microsensors. Mar. Ecol. Prog. Ser. 223:114.

Lee, H.-Y., Hong, Y.-N. \& Chow, W. S. 2001. Photoinactivation of photosystem II complexes and photoprotection by non-functional neighbours in Capsicum annun L. leaves. Planta 212:33242.

Legendre, L., Ackley, S. F., Dieckmann, G. S., Gulliksen, B., Horner, R., Hoshiai, T., Melnikov, I. A., Reeburgh, W. S., Spindler, M. \& Sullivan, C. W. 1992. Ecology of sea ice biota. 2. Global significance. Polar Biol. 12:429-44.

Lizotte, M. P. \& Sullivan, C. W. 1991. Rates of photoadaptation in sea ice diatoms from McMurdo Sound, Antarctica. J. Phycol. 27:367-73

Lizotte, M. P. \& Sullivan, C. W. 1992. Biochemical composition and photosynthate distribution in sea ice microalgae of McMurdo Sound, Antarctica: evidence for nutrient stress during the spring bloom. Antartic Sci. 4:23-30.

McMinn, A., Ashworth, C. \& Ryan, K. G. 1999. Growth and productivity of Antarctic sea ice algae under PAR and UV irradiances. Bot. Mar. 42:401-7.

McMinn, A., Ashworth, C. \& Ryan, K. G. 2000. In situ net primary productivity of an Antarctic fast ice bottom algal community. Aquat. Microb. Ecol. 21:177-85.

McMinn, A. \& Hattori, H. 2006. Effect of time of day on the recovery from light exposure in ice algae from Saromo Ko Lagoon, Hokkaido. Polar Biosci. 20:30-6.

McMinn, A., Ryan, K. G. \& Gademann, R. 2003. Photoacclimation of Antarctic fast ice algal communities determined by pulse amplitude modulation (PAM) fluorometry. Mar. Biol. 143:35967.

McMinn, A., Ryan, K. G., Ralph, P. J. \& Pankowshi, A. 2007. Spring sea ice photosynthesis, primary production and biomass distribution in eastern Antarctica, 2002-2004. Mar. Biol. 151:98599.

Palmisano, A. C., SooHoo, J. B. \& Sullivan, C. W. 1985. Photosynthesis irradiance relationships in sea ice microalgae from McMurdo Sound, Antarctica. J. Phycol. 21:341-6.

Prezelin, B. B. \& Matlick, H. A. 1980. Time course of photoadaptation in the photosynthesis irradiance relationship of a dinoflagellate exhibiting photosynthetic periodicity. Mar. Biol. 58:85-96.

Quinn, G. P. \& Keough, M. J. 2002. Experimental Design and Data Analysis for Biologists. Cambridge University Press, Cambridge, UK, 537 pp.

Ralph, P. J. \& Gademann, R. 2005. Rapid light curves: a powerful tool to assess photosynthetic activity. Aquat. Bot. 82:222-37.

Ralph, P., McMinn, A. \& Ryan, K. G. 2005. Short-term effect of temperature on the photokinetics of microalgae from the surface layers of Antarctic pack ice. J. Phycol. 41:763-9.

Ralph, P., Ryan, K. G., Martin, A. \& Fenton, G. 2007. Melting-out of sea-ice algae causes greater photosynthetic stress than freezingin. J. Phycol. 43:948-56.

Robinson, D. H., Kolber, Z. \& Sullivan, C. W. 1997. Photophysiology and photoacclimation in surface sea ice algae from McMurdo Sound, Antarctica. Mar. Ecol. Prog. Ser. 147:243-56.

Rozanska, M., Poulin, M. \& Gosselin, M. 2008. Protist entrapment in newly formed sea ice in the coastal Arctic Ocean. J. Mar. Syst. 74:887-901.

Ryan, K. G., Ralph, P. J. \& McMinn, A. 2004. Photoacclimation of Antarctic bottom ice algal communities to lowered salinities during melting. Polar Biol. 27:679-86.

Schreiber, U., Bilger, W. \& Neubauer, C. 1994. Chlorophyll fluorescence as a non intrusive indicator for rapid assessment of in vivo photosynthesis. Ecol. Stud. 100:49-70.

Tyystjärvi, E., Ali-Yrkko, K., Kettunen, R. \& Aro, E. M. 1992. Slow degradation of the $\mathrm{D} 1$ protein is related to the susceptibility of low-light-grown pumpkin plants to photoinhibition. Plant Physiol. 100:1310-7. 


\title{
MELTING OUT OF SEA ICE CAUSES GREATER PHOTOSYNTHETIC STRESS IN ALGAE
} THAN FREEZING IN $^{1}$

\author{
Peter J. Ralph ${ }^{2}$ \\ Research Institute for Water and Environmental Resource Management, University of Technology, Sydney, P.O. Box 123 Broadway,
} NSW 2007, Australia

Ken G. Ryan, Andrew Martin

School of Biological Sciences, Victoria University of Wellington, P.O. Box 600, Wellington, New Zealand and Glenn Fenton

Industrial Research Limited, P.O. Box 31 310, Lower Hutt, New Zealand

Sea ice is the dominant feature of polar oceans and contains significant quantities of microalgae. When sea ice forms and melts, the microalgal cells within the ice matrix are exposed to altered salinity and irradiance conditions, and subsequently, their photosynthetic apparatuses become stressed. To simulate the effect of ice formation and melting, samples of sea-ice algae from Cape Hallett (Antarctica) were exposed to altered salinity conditions and incubated under different levels of irradiance. The physiological condition of their photosynthetic apparatuses was monitored using fast and slow fluorescence-induction kinetics. Sea-ice algae exhibited the least photosynthetic stress when maintained in $35 \%$ and $51 \%$ salinity, whereas 16,21 , and $65 \%$ treatments resulted in significant photosynthetic stress. The greatest photosynthetic impact appeared on PSII, resulting in substantial closure of PSII reaction centers when exposed to extreme salinity treatments. Salinity stress to sea-ice algae was light dependent, such that incubated samples only suffered photosynthetic damage when irradiance was applied. Analysis of fast-induction curves showed reductions in $\mathrm{J}$, $I$, and $P$ transients (or steps) associated with combined salinity and irradiance stress. This stress manifests itself in the limited capacity for the reduction of the primary electron receptor, $Q_{A}$, and the plastoquinone pool, which ultimately inhibited effective quantum yield of PSII and electron transport rate. These results suggest that sea-ice algae undergo greater photosynthetic stress during the process of melting into the hyposaline meltwater lens at the ice edge during summer than do microalgae cells during their incorporation into the ice matrix during the process of freezing.

Key index words: fluorescence; PAM; PEA

\footnotetext{
${ }^{1}$ Received 10 June 2006. Accepted 23 March 2007.

${ }^{2}$ Author for correspondence: e-mail peter.ralph@uts.edu.au.
}

Abbreviations: DIC, dissolved inorganic carbon; $F$, minimum fluorescence in light; $F_{m}$, maximum fluorescence in dark; $F_{\mathrm{m}}^{\prime}$, maximum fluorescence in light; $F_{\mathrm{o}}$, minimum fluorescence in dark; $F_{\mathrm{v}} / F_{\mathrm{m}}$, maximum quantum yield of PSII; LHCII, lightharvesting complex on PSII; NPQ, nonphotochemical quenching; OEC, oxygen-evolving complex; P680, PSII reaction center; PAM, pulse amplitude modulated; PEA, plant efficiency analyzer; $P Q$, plastoquinone; $Q_{A}$, primary electron acceptor; $Q_{B}$, secondary electron acceptor; rETR $_{\text {max }}$ maximum relative electron transport rate; RLC, rapid light curve; $\Phi_{P S I I}$, effective quantum yield of PSII

Sea ice is the dominant feature of polar oceans and exerts a unique influence on marine ecosystems in Antarctica. Sea-ice cover varies annually in a concentric zone around the Antarctic continent. During winter as much as 20 million $\mathrm{km}^{2}$ of sea ice forms in the Southern Ocean; however, during the austral summer, only 4 million $\mathrm{km}^{2}$ remains (Horner 1985). Although sea ice represents a harsh physicochemical environment with steep vertical gradients in temperature, light, salinity, and nutrient concentrations (Arrigo and Sullivan 1992), diverse microbial communities are present in the brine inclusions and on the under surface of sea ice that are integral to the ecosystem of the Southern Ocean (Garrison 1991).

Microalgae are a critical component of the sea-ice ecosystem, as they are the main food source for under-ice grazers, and they contribute to the iceedge bloom when the sea ice melts in late summer. Their contribution to primary production in icecovered regions has been estimated to be $\sim 30 \%$ (Arrigo et al. 1997). However, growth in association with sea ice provides a unique set of environmental constraints for microalgae. For example, these microalgae are exposed to a wide range of salinities 
during their growing season. As pelagic algae become incorporated into the growing sea-ice lattice in winter, they are confined into microscopic channels and pockets within the ice that contain hypersaline brine (Gleitz and Thomas 1992). Brine channels provide a niche for sea-ice algae where salinity can exceed $100 \%$ (Gleitz et al. 1995). Shortterm fluctuations in salinity occur within the sea-ice matrix due to convection currents and drainage of brine channels (Bates and Cota 1986). Furthermore, as the sea ice melts in late spring and summer, low salinity meltwater dilutes the brine surrounding the algal cells and eventually releases them back into the pelagic ecosystem. These microalgae, therefore, become exposed to hyposaline conditions at the ice edge, where salinities may be $<10 \%$. Algal blooms regularly occur during summer at the ice edge (Smith and Nelson 1985), and the newly released algal cells will be subjected to salinity shock (Arrigo and Sullivan 1992).

There have been relatively few studies on the physiological impact on microalgae during sea-ice formation, in comparison to the decay and melting of sea ice (Gleitz and Thomas 1992). During the process of ice formation, the salinity of the interstitial brine can increase to $>60 \%$ (Vargo et al. 1986, Palmisano et al. 1987). It is important to understand the physiological impact on these microalgae during their incorporation into the sea-ice matrix, as these physicochemical conditions will provide a selection pressure that influences the final community composition (Ryan et al. 2004).

Salinity stress in plant cells can manifest itself as osmotic and ionic stress. Osmotic stress reversibly inactivates the photosynthetic apparatus due to shrinkage of the intracellular space in conjunction with the efflux of water, whereas ionic stress is due to ion movement and directly impacts both photosynthetic and respiratory electron transport (Allakhverdiev et al. 2000). Changes in salinity affect the growth and photosynthetic condition of sea-ice algae (Vargo et al. 1986). Indeed, salinity stress may even exert a greater selective pressure on sea-ice algae than temperature or nutrient limitations (Meguro et al. 1967). Some sea-ice algal species, such as Fragilariopsis curta (Van Heurck) Hust. and Entomoneis kjellmanii (Cleve) Poulin et Cardinal, tolerate a wide range of salinities, while other species, such as Cylindrotheca closterium (Ehrenb.) Lewin et Reimann, are more sensitive to altered salinity (Ryan et al. 2004). Short-term salinity adjustments within the sea-ice habitat (osmotic and ionic shock) occur over minutes, whereas long-term salinity acclimation requires days to weeks (Arrigo and Sullivan 1992). Therefore, those species that are better able to cope with the changes in salinity may have an advantage and become the dominant species in the ice-edge community.

At the cellular level, salinity changes can result in a wide range of physiological impacts, including cell rupture, reduced photosynthesis, and damage to enzymes. For example, if a cell does not have the photosynthetic activity to generate sufficient ATP/NADPH to maintain membrane-bound ionic pumps (which prevent uncontrolled entry of ions into the cell), then damage will occur to sensitive membranes/metabolic sites, and the cell will die (Gilmour et al. 1985, Maxwell et al. 1994). Furthermore, an accumulation of ions in the chloroplast will result in damage to PSII, especially in the presence of light (Lu et al. 2003). Similarly, salinity acclimation requires energy for both maintenance of ionic pumps and synthesis of osmolytes. Production of low-molecular-weight osmolytes (such as proline) balances the ionic pressure during changes in salinity and assists with cryopreservation (Gleitz and Thomas 1992).

Salinity stress generally results in inhibition of photosynthesis, which can be monitored using chl $a$ fluorescence ( $\mathrm{Lu}$ and Vonshak 2002, Xia et al. 2004). Chlorophyll $a$ fluorescence has been widely used to monitor the photosynthetic apparatus of sea-ice algae (Bates and Cota 1986, Robinson et al. 1998, McMinn et al. 2003, Ryan et al. 2004, Ralph et al. 2005). This technique provides a rapid, noninvasive assessment of the photosynthetic apparatus. When dark-adapted tissue is exposed to intense light, it causes a polyphasic rise in fluorescence, known as the Kautsky effect. This rise can be separated into two domains, the fast-rise kinetics (0-2000 $\mathrm{ms}$ ) and the slow kinetics (up to $2 \mathrm{~min}$ ). The initial rise from the base fluorescence $\left(\mathrm{O} \cong F_{\mathrm{o}}\right)$ to the maximum peak $\left(\mathrm{P} \cong F_{\mathrm{m}}\right)$ takes about 1000 $2000 \mathrm{~ms}$. When the induction rise in fluorescence is measured at high temporal resolution $(\mu \mathrm{s})$, several inflections become apparent. Changes during the rise of the fluorescence signal are defined by four transients (or steps): O-J-I-P (Hill et al. 2004). The $\mathrm{O}-\mathrm{J}$ transient occurs as an electron is passed from the PSII reaction center (P680) to the primary electron acceptor $\left(Q_{\mathcal{A}}\right)$, so the slope of this transient is linked to the condition of the oxygen-evolving complex (OEC) and the functionality of PSII reaction centers. The J-I transient is linked to the reoxidation of $Q_{A}$ by the secondary electron acceptor $\left(Q_{B}\right)$ such that the I step is linked to the accumulation of $\mathrm{Q}_{\mathrm{A}}{ }^{-} \mathrm{Q}_{\mathrm{B}}{ }^{-}$. The $\mathrm{P}$ peak occurs once the plastoquinone (PQ; including $\mathrm{Q}_{\mathrm{A}}$ and $\mathrm{Q}_{\mathrm{B}}$ ) pool is filled. If $\mathrm{PQ}$ has been fully oxidized during dark adaptation, then $Q_{A}$ is fully reduced when the $\mathrm{P}$ peak is reached (Hill et al. 2004). The kinetic changes during the slow induction of PSII can be measured during exposure to actinic light:

$$
\Phi_{\mathrm{PSII}}=\frac{F_{\mathrm{m}}^{\prime}-F}{F_{\mathrm{m}}^{\prime}}
$$

where the ratio of minimum $(\mathrm{F})$ and maximum fluorescence $\left(F_{\mathrm{m}}^{\prime}\right)$ is used to assess effective quantum yield of PSII. 
Under natural conditions, stress usually occurs in combinations. Salinity stress has been examined in conjunction with light or temperature stress, yet few investigations have examined all three stresses in combination (Lu et al. 2003). In this series of experiments, we simulate the process of sea-ice melting and freezing to examine the physiological impact on the photosynthetic apparatus of the sea-ice algal community, using both fast and slow fluorescence kinetics. Sea-ice algae were slowly acclimated to a range of salinities over $7 \mathrm{~h}$ under low light and then exposed to three irradiance treatments for an additional $3 \mathrm{~h}$.

\section{MATERIALS AND METHODS}

Sample-collection. Sea-ice algae were collected from $20 \mathrm{~cm}$ diameter cores cut from the bottom of $1.5 \mathrm{~m}$ thick sea ice at Cape Hallett, Antarctica $\left(72^{\circ} 19^{\prime} \mathrm{S}, 170^{\circ} 13^{\prime} \mathrm{E}\right)$, using a custommade ice-coring drill. During collection, the cores were protected from light damage by performing all operations underneath a black sheet and transporting the core in a black plastic tube. Bottom-ice algal cells were removed from the ice cores by cutting off the bottom $1 \mathrm{~cm}$ of the core and melting this into three times the quantity of filtered seawater $(35 \%$, $\left.0.22 \mu \mathrm{m},-1.8^{\circ} \mathrm{C}\right)$ under low light $(<1 \mu \mathrm{mol}$ photons. $\mathrm{m}^{-2} \cdot \mathrm{s}^{-1}$ ) over a period of $12 \mathrm{~h}$ (following the procedures in Ryan et al. 2004). After melting, samples of sea-ice algae were concentrated using a $0.22 \mu \mathrm{m}$ filter (Millipore, Billerica, MA, USA) under minimal vacuum. A total of 10 cores were combined to make a sufficient volume of concentrated microalgal stock for subdivision into five different salinity treatments $(360 \mathrm{~mL}$ each). The concentrated algal stock solution was stored overnight $(\sim 16 \mathrm{~h})$ in a dark, cold box $\left(35 \%\right.$ oo, $\left.-1.8^{\circ} \mathrm{C}\right)$.

Salinity-adjustment protocol. Sea-ice algal communities held at different salinities were prepared over a period of $35 \mathrm{~h}$ to minimize salinity, temperature, and irradiance shock. The concentrated algal stock $(35 \%)$ was subdivided, and salinity was adjusted with filtered $(0.22 \mu \mathrm{m}$; Millipore $)$ seawater or buffered freshwater (2.2 $\mathrm{mM}$ bicarbonate). To gradually adjust the salinity of these samples, a prescribed volume of water of an appropriate salinity was added hourly to each sample over a 7-hour period. Small aliquots of freshwater were used to serially dilute the $35 \%$ stock containing the algal suspension to reach a final salinity of $16 \%$. Similarly, $13 \%$ seawater was used to dilute the $35 \%$ solution to reach the final salinity of $21 \% ; 35 \%$ seawater was used for the $35 \%$ treatment; concentrated $57 \%$ seawater was used for the $51 \%$ treatment; and $77 \%$ seawater was used for the $64 \%$ treatment. During the salinity-adjustment phase $(7 \mathrm{~h})$, the physiological state of the cells was assessed with a pulse-amplitude-modulation (PAM) fluorometer (WaterPAM; Walz GmbH, Effeltrich, Germany) using rapid light curves (RLCs) of small $(3 \mathrm{~mL})$ aliquots drawn from the sample bottles $1 \mathrm{~h}$ after each salinity adjustment. This process was repeated each hour until the desired salinity was reached. All salinity adjustments were conducted under low-light conditions $\left(<1 \mu \mathrm{mol}\right.$ photons $\left.\cdot \mathrm{m}^{-2} \cdot \mathrm{s}^{-1}\right)$. Salinity and irradiance treatments used in these experiments were ecologically relevant to conditions in Antarctica during late summer (Palmisano et al. 1987, Arrigo and Sullivan 1992, Gleitz and Thomas 1992, Kirst and Wiencke 1995).

Irradiance exposure protocol. Sea-ice algae samples that had been adjusted to five salinities were incubated in $15 \mathrm{~mL}$ centrifuge tubes under a range of irradiances for $3 \mathrm{~h}$ at $-0.7^{\circ} \mathrm{C}$. Samples were randomly assigned to three irradiance treatments: 0,38 , and $150 \mu \mathrm{mol}$ photons $\cdot \mathrm{m}^{-2} \cdot \mathrm{s}^{-1}$. The custom-built incubator maintained $-0.7 \pm 0.1^{\circ} \mathrm{C}$ using a heater/stirrer (Julabo EC; Julabo, Germany) with an ethanol:water (1:4) mixture running through a $10 \mathrm{~m}$ copper heat exchanger buried in the sea ice. After $3 \mathrm{~h}$ irradiance treatment, samples were centrifuged at $2000 \mathrm{rpm}$ for $5 \mathrm{~min}$ in darkness at $-1.0 \pm 0.5^{\circ} \mathrm{C}$ (this was the dark-adaptation period), and then fast-induction kinetics were measured using a Plant Efficiency Analyser fluorometer (PEA; Hansatech Instruments Ltd., King's Lynn, UK). Samples were resuspended in the centrifuge tube and returned to the incubator for an additional $20 \mathrm{~min}$, and then an RLC was performed using a Water-PAM fluorometer (Walz GmbH).

Fast-induction curves. Fast-induction-curve analysis was performed using a PEA fluorometer. Illumination was provided by an array of six light-emitting diodes (650 nm; maximum excitation $3200 \mu \mathrm{mol}$ photons $\cdot \mathrm{m}^{-2} \cdot \mathrm{s}^{-1}$ ) focused on a $4 \mathrm{~mm}$ sampling area. The PEA system used a preamplifier, set to $10 \times$ gain and a temperature-adjusted digital offset. Algal samples were concentrated into a pellet in the end of a $15 \mathrm{~mL}$ centrifuge tube for fast-induction-kinetics analysis. Samples were dark adapted for 5 min (during centrifugation); this was found to give identical results to a 20 min dark adaptation (data not shown). For optimal polyphasic response, we used $100 \%$ irradiance and $2 \mathrm{~s}$ illumination. The fluorescence signal was recorded every $10 \mu \mathrm{s}$ for the first $2 \mathrm{~ms}$, every $1 \mathrm{~ms}$ for the first $1 \mathrm{~s}$ of the sampling, and then every $100 \mathrm{~ms}$ until $2 \mathrm{~s}$. Data were transferred to a PC using WinPEA (Hansatech Instruments Ltd., King's Lynn, UK). All curves were normalized to $\mathrm{O}$ (fluorescence yield at $50 \mu \mathrm{s} \cong F_{\mathrm{o}}$ ) to eliminate any changes in gross chl content. The $\mathrm{O}-\mathrm{J}-\mathrm{I}-\mathrm{P}$ transients from the fastinduction curves were measured at the following times $(\mathrm{O}, 0.05 \mathrm{~ms}$; J, $2 \mathrm{~ms}$; I, $50 \mathrm{~ms}$; P, 1000-2000 ms). Maximum quantum yield $\left(F_{\mathrm{v}} / F_{\mathrm{m}}\right)$ was determined by measuring minimum fluorescence $\left(F_{\mathrm{o}}=\mathrm{O}\right)$, maximum fluorescence $\left(F_{\mathrm{m}}=\mathrm{P}\right)$, and variable fluorescence $\left(F_{\mathrm{v}}=F_{\mathrm{m}}-F_{\mathrm{o}}\right)$.

Slow-induction kinetics. Slow-induction kinetics were measured using a Water-PAM. The Water-PAM was calibrated using the following settings (measuring light frequency $=6$, saturating intensity $=12$, saturating width $=0.6$, photomultiplier gain $=19$ ). Rapid light curves were performed using irradiance ranging from 0 to $400 \mu \mathrm{mol}$ photons $\cdot \mathrm{m}^{-2} \cdot \mathrm{s}^{-1}$ in eight steps of $10 \mathrm{~s}$ each. For details on RLC analysis (estimation of maximum relative electron transport rate $\left.\left[\mathrm{rETR}_{\max }\right]\right)$ and interpretation, see Ralph and Gademann (2005). Initial effective quantum yield of PSII $\left(\Phi_{\mathrm{PSII}}=\left[F_{\mathrm{m}}^{\prime}-F\right] / F_{\mathrm{m}}^{\prime}\right)$ was taken as the first effective quantum yield determination of the RLC.

Cell identification and cell density. At the completion of the PEA analysis, a sample of each treatment was fixed in $0.5 \%$ glutaraldehyde and returned to the Victoria University of Wellington (New Zealand) for analysis of cell density. A $0.5 \mathrm{~mL}$ aliquot of this material was counted on inverted microscope (Axiovert; Carl Zeiss GmbH, Germany) using phase contrast optics until a minimum of 2000 cells per sample were counted.

Statistics. One-way analysis of variance (ANOVA) was used to detect differences among the salinity treatments at each of the irradiance levels. The assumption of normality and equal variance was satisfied. Tukey's post hoc test was used to identify which salinity treatments were significantly different.

\section{RESULTS}

Microscopic examination of glutaraldehyde-fixed samples showed a mixed community of pennate diatoms dominated by Nitzschia stellata Manquin and, to a lesser extent, Fragillariopsis curta. The average cell density at the end of the incubation was $7.8 \pm 0.9 \times 10^{4}$ cells $\cdot \mathrm{mL}^{-1}(n=11)$. 
Salinity treatments. Overall, sea-ice algal samples exposed to a range of salinity treatments maintained moderately constant photosynthetic health during the 7-hour adjustment phase. Specifically, samples held in $35 \%$ seawater had an initial effective quantum yield of $<0.53$, which rose steadily to a maximum of 0.56 (Fig. 1a). The $\Phi_{\text {PSII }}$ for the $21 \%$ samples also increased to a similar level as the $35 \%$ treatment, while the $51 \%$ treatment was slightly lower. The $\Phi_{\text {PSII }}$ for the other treatments $(16 \%$ and $64 \%$ ) either declined or did not change during the salinity-adjustment phase. One-factor ANOVA of the 7-hour results showed the $\Phi_{\text {PSII }}$ values to be significantly different $(F=36.52, P<0.001)$, and Tukey's test indicated that the $16 \%$ and $64 \%$ o treatments were different from the remaining treatments. The RLCs performed during the salinity-adjustment phase showed that the $51 \%$ and $64 \%$ o treatments resulted in a decline in the $\mathrm{rETR}_{\max }$ within $3 \mathrm{~h}$ (Fig. 1b). After $7 \mathrm{~h}$, the rETR $_{\max }$ in the $64 \%$ solution was almost half that of the other treatments. One-factor ANOVA of the 7-hour results showed the rETR $_{\max }$ values to be highly significantly different

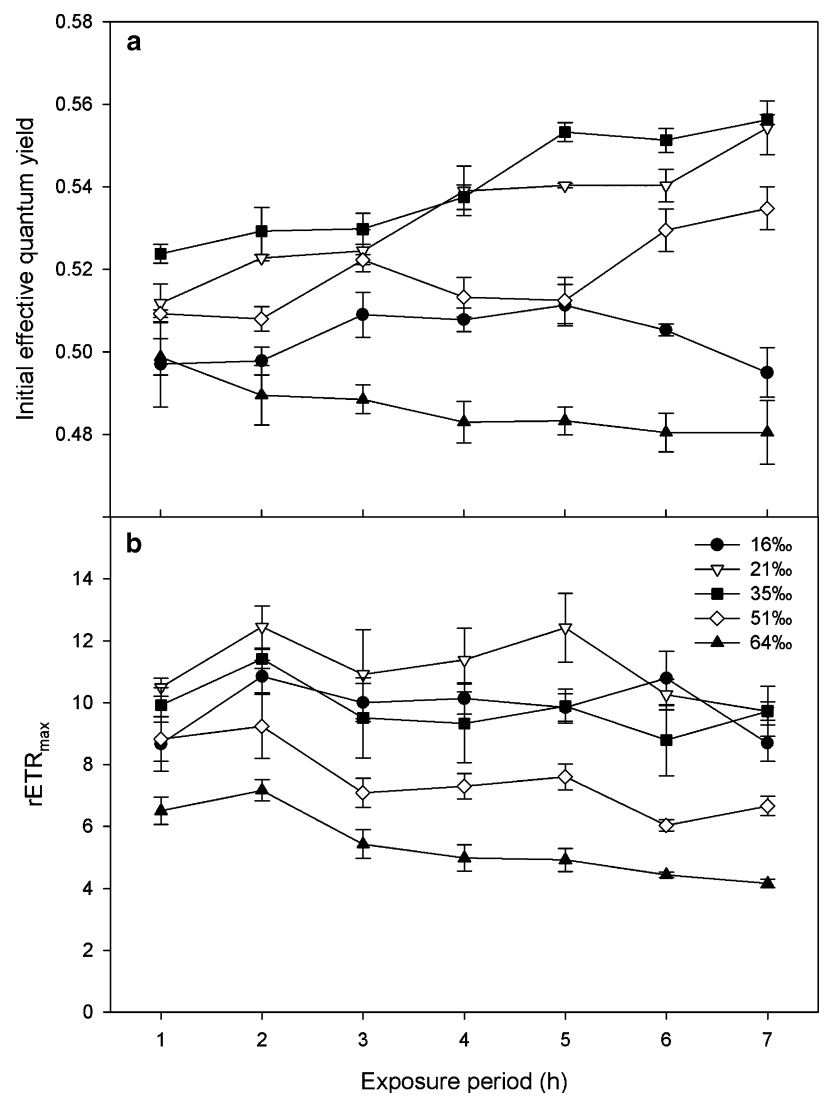

FIG. 1. Effect of salinity adjustment $(16,21,35,51$, and $64 \%$ o on photosynthesis of sea-ice algae over a 7 -hour exposure period. (a) Initial effective quantum yield $\left(\Phi_{\mathrm{PSII}}\right)$ and (b) maximum relative electron transport rate $\left(\mathrm{rETR}_{\max }\right)$. Mean values with standard error of the mean $(n=4)$.
$(F=25.46, \quad P<0.001)$, and Tukey's test indicated that the $51 \%$ and $64 \%$ treatments were different from the remaining treatments.

Irradiance incubations-slow-induction curves. A complex interaction was observed when salinity and irradiance stresses were applied simultaneously. Fig. 2a shows that $\Phi_{\text {PSII }}$ values for samples exposed to darkness and to moderate light $(38 \mu \mathrm{mol}$ photons $\cdot \mathrm{m}^{-2} \cdot \mathrm{s}^{-1}$ ) were similar and photosynthetically healthy across most salinity treatments. Samples exposed to high light $(150 \mu \mathrm{mol}$ photons . $\mathrm{m}^{-2} \cdot \mathrm{s}^{-1}$ ) showed a peak in $\Phi_{\mathrm{PSII}}$ at $35 \%$ salinity, but reduced photosynthetic efficiency in all other salinity treatments. Normal salinity and high light $\left(35 \%\right.$ and $150 \mu \mathrm{mol}$ photons $\left.\cdot \mathrm{m}^{-2} \cdot \mathrm{s}^{-1}\right)$ provided the optimal photosynthetic conditions for sea-ice algae, resulting in the highest $\mathrm{rETR}_{\max }$ (Fig. 2b). Samples at suboptimal irradiance $(38 \mu \mathrm{mol}$ photons $\cdot \mathrm{m}^{-2} \cdot \mathrm{s}^{-1}$ ) had a similar yet lower photosynthetic response to the range of salinity conditions. Reduced photosynthetic activity occurred in both hypo- and hypersaline treatments for both moderate- and high-irradiance levels. Maintaining

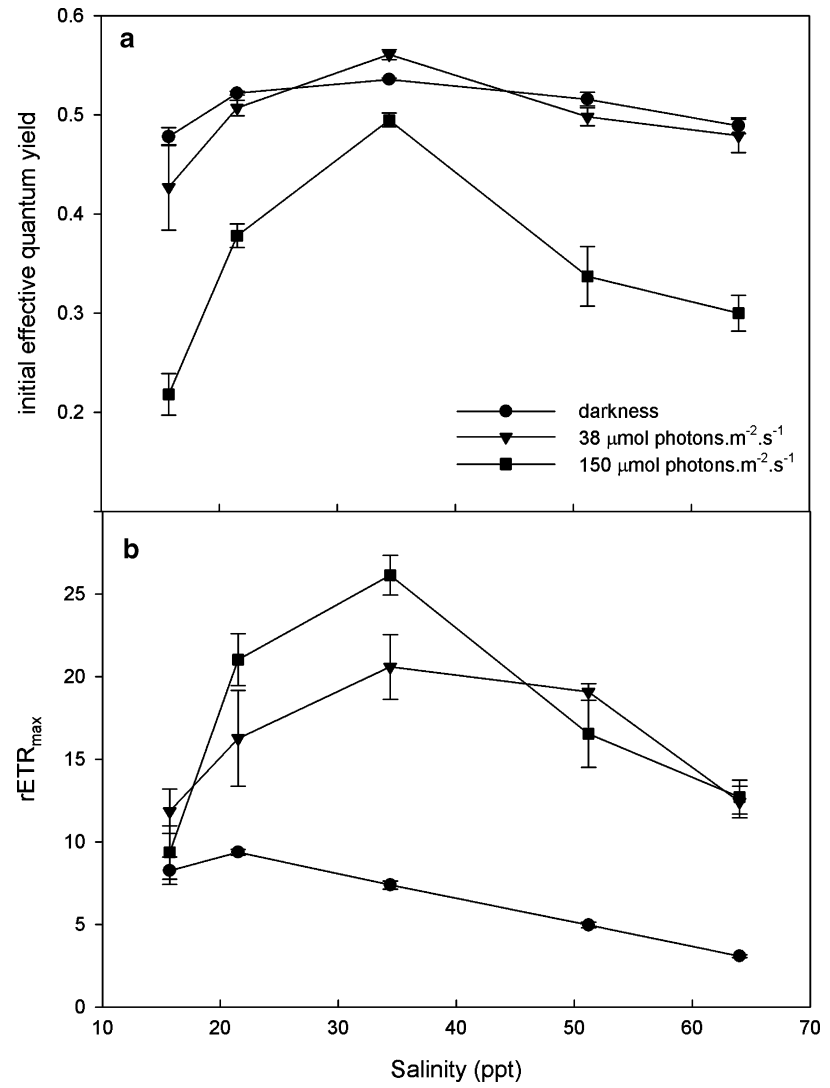

FIG. 2. Effect of salinity adjustment $(16,21,35,51$, and $64 \%$ ) on photosynthesis of sea-ice algae maintained for $3 \mathrm{~h}$ under three irradiance treatments (darkness and 38 and $150 \mu \mathrm{mol}$ photons $\left.\cdot \mathrm{m}^{-2} \cdot \mathrm{s}^{-1}\right)$. (a) Initial effective quantum yield $\left(\Phi_{\mathrm{PSII}}\right)$ and (b) maximum relative electron transport rate $\left(\mathrm{rETR}_{\max }\right)$. Mean values with standard error of the mean $(n=4)$. 
the microalgae in darkness resulted in the lowest rETR $_{\max }$, which decreased with increasing salinity.

Irradiance incubations-fast-induction curves. Two representative sets of fast-induction curves are presented in Figures 3 and 4, showing typical responses to a range of irradiances and adjusted salinity treatments. Figure 3 depicts a selection of average fast-induction curves of sea-ice algae exposed to seawater $(35 \%$ ) with different irradiance treatments. As expected, treatments at $35 \%$ did not induce a salinity stress response, but exposure to $150 \mu \mathrm{mol}$ photons $\cdot \mathrm{m}^{-2} \cdot \mathrm{s}^{-1}$ resulted in a substantial change to the fast-induction curve. In comparison to the preexposure curve, the $\mathrm{J}$ (and therefore $\mathrm{P}$ ) peak was reduced in amplitude, and the I step was completely lost. The preexposure average samples had a higher $\mathrm{P}$ peak than the dark and $38 \mu \mathrm{mol}$ photons $\cdot \mathrm{m}^{-2} \cdot \mathrm{s}^{-1}$ samples, while all curves (except $150 \mu \mathrm{mol}$ photons $\cdot \mathrm{m}^{-2} \cdot \mathrm{s}^{-1}$ ) had similar $\mathrm{J}$ and $\mathrm{I}$ steps.

Figure 4 shows the effect of $150 \mu \mathrm{mol}$ photons $\cdot \mathrm{m}^{-2} \cdot \mathrm{s}^{-1}$ irradiance on samples of sea-ice algae held at different salinities. The average fastinduction curves of the two extreme salinity treatments $(16 \%$ and $64 \%$ o were lower than the three intermediate salinity treatments $(21,35$, and $51 \%$ o $)$. Once again, the extreme salinity treatments had a reduced $\mathrm{P}$ peak, while all curves appear to have lost the I step. Fast-induction curves for samples held in darkness and $38 \mu \mathrm{mol}$ photons $\cdot \mathrm{m}^{-2} \cdot \mathrm{s}^{-1}$ show a similar pattern to those in Figure 4, and the values of the O-J-I-P transients are compared in Table 1.

There was no significant difference in the O-JI-P transients among the five salinity treatments under dark conditions (Table 1). Exposing the microalgae to moderate irradiance $(38 \mu \mathrm{mol}$ photons . $\mathrm{m}^{-2} \cdot \mathrm{s}^{-1}$ ) resulted in a complex pattern of O-J-I-P transient values. At moderate irradiance, the $21 \%$

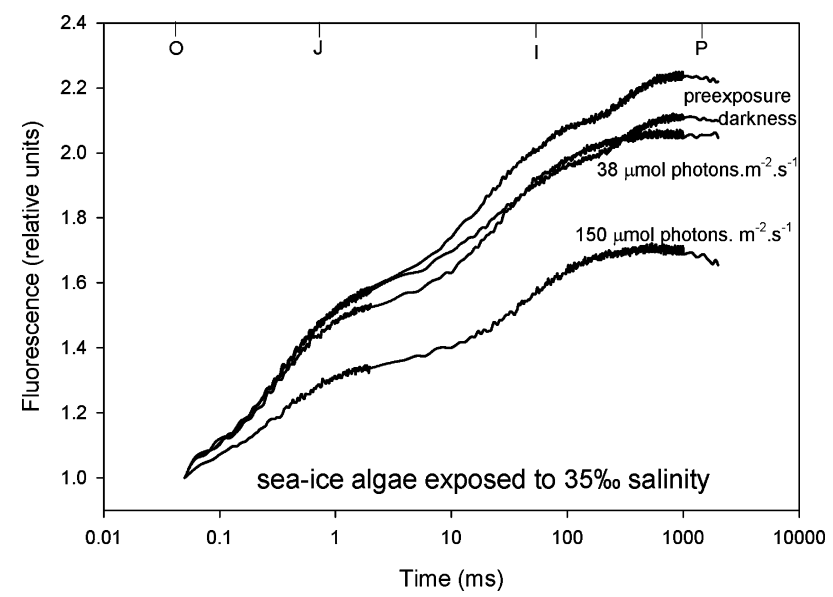

FIG. 3. Average fast-induction curve of $35 \%$ samples of sea-ice algae measured preexposure and after $3 \mathrm{~h}$ exposure to three irradiance treatments $(n=4)$. Curves have been normalized to $\mathrm{O}$ value.

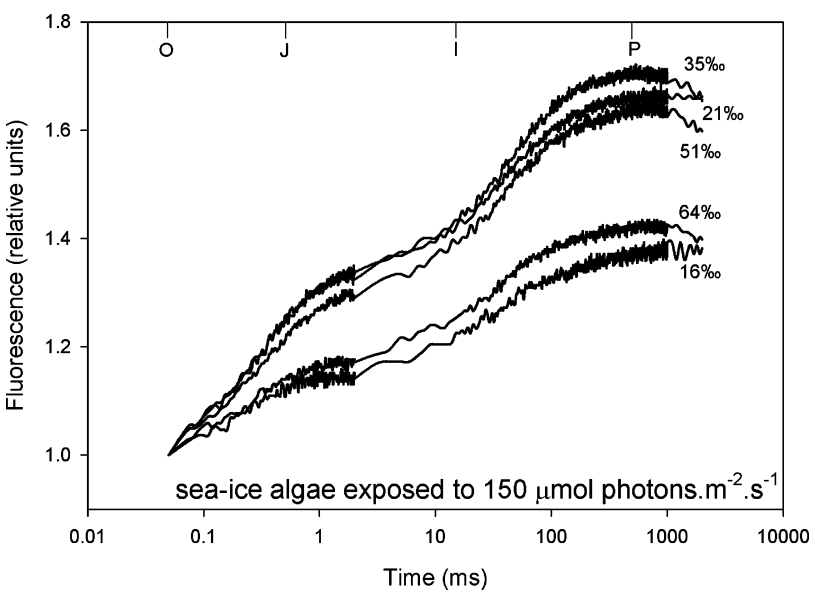

FIG. 4. Average fast-induction curve of samples of sea-ice algae maintained in various salinities $(16,21,35,51$, and $64 \%$ ) and exposed to $150 \mu \mathrm{mol}$ photons $\cdot \mathrm{m}^{-2} \cdot \mathrm{s}^{-1}$ for $3 \mathrm{~h}(n=4)$. Curves have been normalized to $\mathrm{O}$ value.

and $51 \%$ treatments generally had higher transient values than the 16,35 , and $64 \%$ o treatments, which were not significantly different from each other $(P>0.05 ; \quad$ Table 1$)$. The $150 \mu \mathrm{mol}$ photons . $\mathrm{m}^{-2} \cdot \mathrm{s}^{-1}$ treatment caused a substantial change in most $\mathrm{O}-\mathrm{J}-\mathrm{I}-\mathrm{P}$ transients between the salinity treatments $(P<0.05$; Table 1$)$. The $51 \%$ treatment consistently had the highest values of $\mathrm{O}, \mathrm{J}, \mathrm{I}$, and $\mathrm{P}$, while the $16 \%$ treatment had the lowest values, and the remaining treatments were intermediate between these two extremes.

\section{DISCUSSION}

Salinity has wide-ranging effects on plant growth, photosynthetic efficiency, and metabolism (Misra et al. 2001). Specifically, salinity can alter PSII photochemical efficiency, charge separation of PSII, and the integrity of the thylakoid membrane (Lu and Vonshak 2002). In this study, sea-ice algae showed evidence of a wide range of photosynthetic responses to both hypo- and hypersalinity in conjunction with irradiance $\left(\Phi_{\mathrm{PSII}}, \mathrm{rETR}_{\max }, \mathrm{O}-\mathrm{J}-\mathrm{I}-\mathrm{P}\right)$; however, the specific pattern was complex. In an early review of the ecophysiology of polar algae, Kirst and Wiencke (1995) speculated that ice algae exposed to low salinity $(<20 \%-25 \%$ oo $)$ conditions would show changes in the efficiency of energy transfer to PSII and noncyclic electron flow; whereas, at elevated salinity $(>35 \%-40 \%)$, the impact on the photosystems of these microalgae would be linked to the inhibition of noncyclic electron flow only. Furthermore, Bates and Cota (1986) observed that most sea-ice algae were more tolerant of reduced, rather than elevated, salinity. Ryan et al. (2004) examined a variety of sea-ice algal species and hypothesized that seawater dilution could cause a wide range of photochemical impacts that varied between species. The present study supports Kirst 
TABle 1. Comparison of O-J-I-P transients of salinity- and irradiance-exposed sea-ice algae.

\begin{tabular}{|c|c|c|c|c|c|}
\hline Irradiance $\left(\mu \mathrm{mol}\right.$ photons $\left.\cdot \mathrm{m}^{-2} \cdot \mathrm{s}^{-1}\right)$ & Salinity $(\%)$ & $\mathrm{O}$ & $\mathrm{J}$ & I & $\mathrm{P}$ \\
\hline \multirow[t]{6}{*}{ Darkness } & 16 & $305 \pm 23$ & $460 \pm 38$ & $536 \pm 34$ & $587 \pm 38$ \\
\hline & 21 & $309 \pm 20$ & $475 \pm 36$ & $571 \pm 25$ & $617 \pm 28$ \\
\hline & 35 & $300 \pm 19$ & $468 \pm 33$ & $582 \pm 37$ & $626 \pm 43$ \\
\hline & 51 & $287 \pm 33$ & $441 \pm 54$ & $543 \pm 56$ & $578 \pm 60$ \\
\hline & 64 & $334 \pm 34$ & $516 \pm 55$ & $634 \pm 67$ & $662 \pm 70$ \\
\hline & $P$-value & 0.783 & 0.812 & 0.606 & 0.776 \\
\hline \multirow[t]{6}{*}{38} & 16 & $243 \pm 13^{\mathrm{a}}$ & $350 \pm 19^{\mathrm{a}}$ & $432 \pm 20^{\mathrm{a}}$ & $485 \pm 21^{\mathrm{a}}$ \\
\hline & 21 & $292 \pm 12^{\mathrm{b}}$ & $452 \pm 22^{\mathrm{b}}$ & $564 \pm 32^{\mathrm{b}}$ & $595 \pm 25^{\mathrm{b}}$ \\
\hline & 35 & $256 \pm 8^{\mathrm{a}}$ & $389 \pm 17^{\mathrm{a}}$ & $505 \pm 22^{\mathrm{a}}$ & $524 \pm 24^{b}$ \\
\hline & 51 & $289 \pm 4^{\mathrm{b}}$ & $438 \pm 11^{b}$ & $575 \pm 13^{\mathrm{b}}$ & $601 \pm 14^{\mathrm{b}}$ \\
\hline & 64 & $276 \pm 17^{\mathrm{b}}$ & $395 \pm 21^{\mathrm{a}}$ & $502 \pm 23^{\mathrm{a}}$ & $520 \pm 29^{a}$ \\
\hline & $P$-value & $0.032 * * *$ & $0.021 * * *$ & $0.014 * * *$ & $0.015^{* * *}$ \\
\hline \multirow[t]{6}{*}{150} & 16 & $182 \pm 16^{\mathrm{a}}$ & $217 \pm 18^{\mathrm{a}}$ & $253 \pm 22^{\mathrm{a}}$ & $267 \pm 28^{\mathrm{a}}$ \\
\hline & 21 & $225 \pm 8^{\mathrm{b}}$ & $306 \pm 12^{\mathrm{b}}$ & $369 \pm 14^{\mathrm{b}}$ & $384 \pm 15^{\mathrm{b}}$ \\
\hline & 35 & $231 \pm 7^{\mathrm{b}}$ & $317 \pm 10^{\mathrm{b}}$ & $387 \pm 8^{\mathrm{b}}$ & $401 \pm 6^{\mathrm{b}}$ \\
\hline & 51 & $259 \pm 13^{c}$ & $362 \pm 20^{c}$ & $448 \pm 26^{c}$ & $470 \pm 23^{c}$ \\
\hline & 64 & $212 \pm 8^{\mathrm{b}}$ & $259 \pm 9^{b}$ & $303 \pm 11^{\mathrm{d}}$ & $319 \pm 12^{\mathrm{d}}$ \\
\hline & $P$-value & $0.005 * * *$ & $<0.005^{* * *}$ & $<0.005^{* * *}$ & $<0.005^{* * *}$ \\
\hline
\end{tabular}

Data are means and standard error of the means $(n=4)$. Units of O-J-I-P are arbitrary. $P$-values are linked to one-factor analysis of variance (ANOVA) results, where $* * *$ indicates $P<0.05$. Superscripted letters indicate similarity according to Tukey's HSD test.

and Wiencke's (1995) pattern, as hypersaline treatments generally produced more photosynthetic stress symptoms than hyposaline treatments (Fig. 1b); yet analysis of fast-induction curves (Table 1) groups the two extreme salinity treatments together $(16 \%$ and $64 \%$ ). Both hypo- and hypersaline treatments resulted in inhibition of noncyclic electron transport (Fig. 2b); however, it could equally be argued that both salinity treatments also reduced the efficiency of energy transfer of PSII (Fig. 4, reduced slope $\mathrm{O}-\mathrm{J}$ ), as noted by Bates and Cota (1986) for hyposaline conditions.

Slow-induction curves. The process of salinity adjustment in these experiments was sufficiently slow and gentle that cells from most treatments (except $16 \%$ and $64 \%$ ) showed a steady improvement in effective quantum yield over the 7-hour adjustment period (Figs. 1 and 2). Samples adjusted to 21,35 , and $51 \%$ all increased in $\Phi_{\text {PSII }}$, which suggests that the $\mathrm{PQ}$ became increasingly oxidized, allowing all photons captured to be used with maximum efficiency, since the samples were held in dim light $\left(<1 \mu \mathrm{mol}\right.$ photons $\left.\cdot \mathrm{m}^{-2} \cdot \mathrm{s}^{-1}\right)$. This improvement in photosynthetic efficiency could also be attributed to increased access to $\mathrm{CO}_{2}$ (however, the medium was not DIC limited). Alternatively, a stateII transition could have occurred ( $\mathrm{Lu}$ et al. 1999), as the cells were maintained in very low light before each RLC measurement. State transitions have been documented as short-term acclimatory processes for a range of phototrophs that adjust to variations in irradiance, salinity, and thermal stress (Gilmour et al. 1985, Lu and Vonshak 2002). During state transitions, the redox state of the PQ regulates the reversible phosphorylation of light-harvesting complexes (LHC). When irradiance increases, a state-II transition occurs as LHCII migrates from PSII to PSI (Morgan-Kiss et al. 2002). State-II transitions could explain the small reduction in $\Phi_{\text {PSII }}$ of the moderate-light samples, which exhibited limited photosynthetic stress across the range of salinity treatments. Maximum quantum yield of PSII $\left(F_{\mathrm{v}} / F_{\mathrm{m}}\right)$ of control samples was 0.56 , as determined from the preexposure samples (Fig. 3). Since the moderate-light treatment was close to the minimum saturating irradiance $\left(E_{\mathrm{k}}, \quad 30 \mu \mathrm{mol}\right.$ photons . $\mathrm{m}^{-2} \cdot \mathrm{s}^{-1}$ ) of Antarctic sea-ice algae, according to Kirst and Wiencke (1995), we suggest that this treatment would cause the least photoinhibitory stress. Further support that state-II transitions could be providing enhanced tolerance under moderate light is evident in the limited variation in $\mathrm{rETR}_{\max }$ between salinity treatments. In contrast, samples exposed to high light were unable to use state-II transitions to protect their photosystems from salinity stress, and so the $\Phi_{\mathrm{PSII}}$ showed a more substantial decline at the extreme salinities.

Extreme salinity treatments illustrate the ecological response of sea-ice algae to processes such as freezing in and thawing out. Photosynthetic activity of cells exposed to the $64 \%$ treatment was impaired (reduced rETR $_{\text {max }}$, Fig. 1b); however, samples were still photosynthetically viable. This finding is confirmed by similar levels of $\mathrm{rETR}_{\max }$ measured in brine algae from pack ice in the vicinity of the Mertz Glacier (Ralph et al. 2005). Both of these data sets contradict the findings of Palmisano et al. (1987), who were unable to detect photosynthetic activity in microalgae exposed to salinity $>60 \%$. Our results suggest that sea-ice algae undergo photosynthetic stress but could survive the salinity, temperature, and irradiance conditions during ice formation.

Salinity stress appears to influence the PSII activity of sea-ice algae that is independent of the absolute quantity of irradiance, provided there is some 
minimum level of irradiance $\quad(<38 \mu \mathrm{mol}$ photons $\cdot \mathrm{m}^{-2} \cdot \mathrm{s}^{-1}$ ) sufficient to drive electron transport. This was confirmed by the observation that all samples maintained in darkness suffered no PSII damage (Table 1; Figs. 2 and 3). Light dependence of salinity stress has been demonstrated for a number of higher plants (Ball and Anderson 1986, Belkhodja et al. 1994). Maintaining sea-ice algae samples at any salinity in darkness does not affect their capacity for charge separation $\left(F_{\mathrm{v}} / \mathrm{F}_{\mathrm{m}}\right.$ or, in this situation, the $\Phi_{\mathrm{PSII}}$ of a dark-adapted sample; Fig. 2). When light excitation pressure was applied to all dark-adapted salinity treatments (including $35 \%$ ) during the RLC, this caused a strong decline in $\Phi_{\text {PSII }}$. This finding would suggest a reduction of the PQ, resulting in an increased proportion of nonfunctional PSII (increasing energy dissipation, evidenced by changes in $\mathrm{O}-\mathrm{J}-\mathrm{I}-\mathrm{P}$ ) and $\mathrm{P} 680^{*}$, both of which ultimately reduce $\Phi_{\text {PSII }}$, as seen in reduced $\mathrm{rETR}_{\max }$. Alternatively, the dark-light transition (dark-RLC) could have induced a state-II transition, which would also reduce $\Phi_{\mathrm{PSII}}$.

Fast-induction curves. Fast-induction-curve analysis provides a powerful way to understand the biophysical changes in the photosynthetic apparatus during the process of salinity adjustment and high-light acclimation. This is the first study to measure fastinduction curves of sea-ice algae. Sea-ice algae exhibited a typical polyphasic rise of fluorescence induction, which is similar to that described for other microalgae (Gilmour et al. 1985, Hill et al. 2004), cyanobacteria ( $\mathrm{Lu}$ and Vonshak 2002), macroalgae (Xia et al. 2004), as well as higher plants (Misra et al. 2001). When sea-ice algae were exposed to high light $(150 \mu \mathrm{mol}$ photons . $\left.\mathrm{m}^{-2} \cdot \mathrm{s}^{-1}\right)$ and extreme salinity $(16 \%$ and $64 \%$ o $)$, the cells exhibited a range of photosynthetic stress symptoms. The first symptom was the PQ becoming increasingly reduced, as evidenced by a reduced difference between the J, I, and P peaks, and a decline in the slope of the polyphasic curve (Fig. 4). Cyanobacteria have a similar response to salinity, which has been attributed to an inhibition of electron transport at the donor side of PSII (Lu and Vonshak 2002). In contrast, salinity stress to the macroalga Ulva lactuca L. affected the acceptor side of PSII, as evidenced by almost complete collapse of fast kinetic transients and no increase beyond J (Xia et al. 2004); sea-ice algae showed substantially more photosynthetic tolerance to salinity stress than this macroalga. Reduced height of the J peak $(16 \%$ and $64 \%$ treatments; Fig. 4) indicated a limited capacity for $Q_{A}$ reduction, leading to a greater proportion of nonfunctional PSII reaction centers. Nonfunctional PSII reaction centers can effectively quench captured energy without transferring energy to drive photosynthetic processes (Lu et al. 1999). This is similar to the response of potato leaves to elevated temperature, where it was speculated that the reduction in $\mathrm{J}$ resulted from a loss of functional
PSII reaction centers, leading to impaired electron transport (Guisse et al. 1995). A reduction in rETR $_{\max }$ (Fig. 2b) was also apparent in the sea-ice samples exposed to extreme salinity treatments.

Reduced PQ leads to reduced $\Phi_{\mathrm{PSII}}$, and this was confirmed by a reduction in electron transport as seen in Figure 2b. This reduction in photosynthetic activity can be attributed to either blockage after PSII or inhibition of electron transport from the PSII donor side (OEC; Lu and Vonshak 2002). Ball and Anderson (1986) suggested that the mechanism of salinity impact on PSII of mangroves was to remove the OEC from its functional site on the thylakoid membrane. The decline in J-I-P that occurred in sea-ice algae has also been observed in cyanobacteria and has been linked to damage to both the donor and acceptor sides of PSII ( $\mathrm{Lu}$ and Vonshak 2002). Reduction of $Q_{A}$ was linked to damage to the acceptor side of PSII ( $\mathrm{Lu}$ and Vonshak 2002). For this series of experiments, it would appear that salinity damage to sea-ice algae occurs at both the donor and acceptor sides of PSII, and blockage of the electron transport may occur as a secondary stress response.

Minimum fluorescence ( $\mathrm{O}$ in Table 1) increased relative to the $35 \%$ o treatment at moderate light (38 $\mu$ mol photons $\cdot \mathrm{m}^{-2} \cdot \mathrm{s}^{-1}$ ), with the exception of $16 \%$. This increase in $\mathrm{O}$ was probably linked to PSII reaction center closure. Alternatively, this could result from dissociation of LHCII from the PSII reaction center (Sudhir and Murthy 2004). At $150 \mu \mathrm{mol}$ photons $\cdot \mathrm{m}^{-2} \cdot \mathrm{s}^{-1}$, the pattern was similar but not as clear, with 21, 35, and $64 \%$ treatments showing similar $\mathrm{O}$ values; $51 \%$ being elevated; and $16 \%$ being reduced due to damage to PSII reaction centers (Maxwell et al. 1994). High light caused an overall reduction in $\mathrm{PQ}(\cong$ slope of the transient curve), resulting in an accumulation of $\mathrm{P} 680^{*}$ (a strong fluorescence quencher) and leading to a significant decline in $\mathrm{O}$ under high-light conditions $(P<0.05$; Table 1$)$. A decline in $\mathrm{J}$ (and therefore $\mathrm{P})$ indicated a block in electron flow to $\mathrm{Q}_{\mathrm{A}}{ }^{-}$. This decline has been reported with higher plants under salinity stress, along with similar impacts at the $\mathrm{Q}_{\mathrm{A}}{ }^{-}$ and $\mathrm{Q}_{\mathrm{B}}{ }^{-}$recombination (Misra et al. 2001). Sea-ice microalgal cells maintained at $35 \%$ were able to cope with elevated excitation pressure on PSII while keeping the majority of $Q_{A}$ oxidized (Fig. 2a; Table 1). This mechanism is a common strategy for low-temperature acclimated algae (Maxwell et al. 1994). A reduction in $\mathrm{P}\left(\cong F_{\mathrm{m}}\right)$ is usually associated with increased nonphotochemical quenching (NPQ). Extreme salinity treatments $(16 \%$ and $61 \%$ ) in conjunction with elevated irradiance showed a significant reduction in $\mathrm{P}$ values, in comparison to the $35 \%$ treatment. This decline in $\mathrm{P}$ could be linked to either the $\mathrm{pH}$ gradient across the thylakoid membrane activating the xanthophyll cycle to dissipate energy (Maxwell et al. 1994, Robinson et al. 1997), or to state-II transitions where LHCII are 
translocated to PSI, changing the photon distribution in favor of PSI ( $\mathrm{Lu}$ and Vonshak 2002). Both of these processes protect the PSII reaction center from the generation of reactive oxygen. To further understand these NPQ processes would require assessment of the degree of photoinhibitory damage, state-transition quenching (Hill et al. 2005), reoxidation kinetics of $\mathrm{Q}_{\mathrm{A}}^{-}$, proportion of nonreducing $\mathrm{Q}_{\mathrm{A}}$ centers, and damage to the $\mathrm{D} 1$ protein.

\section{CONCLUSION}

Salinity stress appears to be dependent on irradiance, as a reduction in photochemical efficiency was clearly apparent when sea-ice microalgae were exposed to $150 \mu \mathrm{mol}$ photons $\cdot \mathrm{m}^{-2} \cdot \mathrm{s}^{-1}$ at either elevated or reduced salinity. Photosynthetic stress symptoms were more apparent with microalgae exposed to hyposaline, as opposed to hypersaline, conditions. Sea-ice algae exposed to hyposaline conditions showed photoacclimation over $7 \mathrm{~h}$; however, they underwent photoinhibitory stress when exposed to irradiances of $150 \mu \mathrm{mol}$ photons $\cdot \mathrm{m}^{-2} \cdot \mathrm{s}^{-1}$. In an ecological context, the microalgae that have melted out of the sea-ice matrix have a photosynthetic optimum at $35 \%$. In addition, we have shown that sea-ice algae undergo considerable photosynthetic stress as they are melted out into hyposaline conditions, such as the meltwater lens at the ice edge. Higher ambient light would cause photoinhibition in cells during melting out, whereas, during freezing in to the ice lattice, the alga would be exposed to increasingly shaded conditions, especially during winter. Cells released into meltwater would exhibit chronic photoinhibition, leading to poor growth potential, reduced survival, and hence a decrease in the standing stock of microalgae capable of seeding the ice-edge phytoplankton bloom. It has been shown that some species within the sea-ice community are more able to adapt to changes in salinity than others, leading to changes in the meltwater bloom composition. The effect of hypersalinity on the same population of cells (freezing in), suggests that less photosynthetic stress occurred and that they showed greater capacity for acclimation. The photosynthetic impact of elevated salinity appears similar to hyposaline exposure; however, cells would only be exposed to moderate light during the process of sea-ice formation. During ice formation where reduced light stress was combined with hypersalinity, these conditions appear to be well tolerated by these sea-ice algal cells, which is probably due to their ability to use state-II transitions along with other physiological adaptations.

We would like to thank Martina Doblin and Ross Hill for editorial comments; Antarctic NZ and Scott Base staff for logistic support; and especially Shulamit Gordon, Gus McAlister, and Rachel Brown for the use of the LGP camp at Cape Hallett. Grants for this work were provided by ARC Discovery (PR, DP0344067) and the New Zealand Foundation for Research
Science and Technology contract no. VICX0219 (KGR). We are grateful to Tony Larkum for the loan of PEA and to Neil Ralph for the manufacture of specialized instruments. IWERM contribution number 213.

Allakhverdiev, S. I., Sakamoto, A., Nishiyama, Y., Inaba, M. \& Murata, N. 2000. Ionic and osmotic effects of NaCl-induced inactivation of photosystem I and II in Synechococcus sp. Plant Physiol. 123:1047-56.

Arrigo, K. R., Lizotte, M. P., Dixon, P. \& Dieckmann, G. 1997. Primary production in Antarctic sea ice. Science 276:394-7.

Arrigo, K. R. \& Sullivan, C. W. 1992. The influence of salinity and temperature covariation on the photophysiological characteristics of Antarctic sea ice microalgae. J. Phycol. 28:746-56.

Ball, M. C. \& Anderson, J. M. 1986. Sensitivity of photosystem II to $\mathrm{NaCl}$ in relation to salinity tolerance. Comparative studies with thylakoids of salt tolerant mangrove, Avicennia marina, and the salt-sensitive pea, Pisum sativum. Aust. J. Plant Physiol. 13:68998.

Bates, S. S. \& Cota, G. F. 1986. Fluorescence induction and photosynthetic response of Arctic ice algae to sample treatment and salinity. J. Phycol. 22:421-9.

Belkhodja, R., Morales, F., Abadia, A., Gomez-Aparisi, J. \& Abadia, J. 1994. Chlorophyll fluorescence as a possible tool for salinity tolerance screening in barley (Hordeum vulgare L.). Plant Physiol. 104:667-73.

Garrison, D. L. 1991. Antarctic sea ice biota. Am. Zool. 31:17-33.

Gilmour, D. J., Hipkins, M. F., Webber, A. N., Baker, N. R. \& Boney, A. D. 1985. The effect of ionic stress on photosynthesis in Dunaliella tertiolecta. Planta 163:250-6.

Gleitz, M., Rutgers, V. D., Loeff, M., Thomas, D. N., Dieckmann, G. S. \& Millero, F. J. 1995. Comparison of summer and winter inorganic carbon, oxygen and nutrient concentrations in Antarctica sea ice brine. Mar. Chem. 51:81-91.

Gleitz, M. \& Thomas, D. N. 1992. Physiological responses of a small Antarctic diatom (Chaetoceros sp.) to simulated environmental constraints associated with sea-ice formation. Mar. Ecol. Prog. Ser. 88:271-8.

Guisse, B., Srivastava, A. \& Straser, R. J. 1995. The polyphasic rise of the chlorophyll $a$ fluorescence (OKJIP) in heat-stressed leaves. Arch. Sci. 48:147-60.

Hill, R., Frankart, C. \& Ralph, P. J. 2005. Impact of bleaching conditions on the components of non-photochemical quenching in the zooxanthellae of a coral. J. Exp. Mar. Biol. Ecol. 322:83-92.

Hill, R., Larkum, A. W. D., Frankart, C., Kühl, M. \& Ralph, P. J. 2004. Loss of functional photosystem II reaction centres in zooxanthellae of corals exposed to bleaching conditions: using fluorescence rise kinetics. Photosynth. Res. 82:59-72.

Horner, R. A. 1985. Ecology of sea ice microalgae. In Horner, R. A. [Ed.] Sea Ice Biota. CRC Press, Boca Raton, Florida, pp. 83-103.

Kirst, G. O. \& Wiencke, C. 1995. Ecophysiology of polar algae. J. Phycol. 31:181-99.

Lu, C., Qiu, N., Wang, B. \& Zhang, J. 2003. Salinity treatment shows no effect on photosystem II photochemistry, but increases the resistance of photosystem II to heat stress in halophyte Suaeda salsa. J. Exp. Bot. 54:851-60.

Lu, C., Torzilo, G. \& Vonshak, A. 1999. Kinetic response of photosystem II photochemistry in cyanobacterium Spirulina platensis to high salinity is characterized by two distinct phases. Aust. J. Plant Physiol. 26:283-92.

Lu, C. \& Vonshak, A. 2002. Effects of salinity stress on photosystem II function in cyanobacterial Spirulina platensis cells. Physiol. Plant. 114:405-13.

Maxwell, D. P., Falk, S., Trick, C. G. \& Huner, N. P. A. 1994. Growth at low temperature mimics high-light acclimation in Chlorella vulgaris. Plant Physiol. 105:535-43.

McMinn, A., Ryan, K. G. \& Gademann, R. 2003. Diurnal changes in photosynthesis of Antarctic fast ice algal communities determined by pulse amplitude modulation (PAM) fluorometry. Mar. Biol. 143:359-67. 
Meguro, H., Ito, K. \& Fukushima, K. 1967. Ice flora (bottom type): a mechanism of primary production in polar seas and the growth of diatoms in sea ice. Arctic 20: 114-33.

Misra, A. N., Srivastava, A. \& Strasser, R. J. 2001. Utilization of fast chlorophyll $a$ fluorescence techniques in assessing salt/ion sensitivity of mung bean and Brassica seedlings. J. Plant Physiol. 158:1173-81.

Morgan-Kiss, R. M., Ivanov, A. G. \& Huner, N. P. A. 2002. The Antarctic psychrophile, Chlamydomonas subcaudata, is deficient in state I-state II transitions. Planta 214:435-45.

Palmisano, A. C., SooHoo, J. B. \& Sullivan, C. W. 1987. Effects of four environmental variables on photosynthesis-irradiance relationships in Antarctic sea ice microalgae. Mar. Biol. 94:299-306.

Ralph, P. J. \& Gademann, R. 2005. Rapid light curves: a powerful tool for the assessment of photosynthetic activity. Aquat. Bot. 82:222-37.

Ralph, P. J., McMinn, A. \& Ryan, K. G. 2005. Short-term effect of temperature on the photokinetics of microalgae from the surface layers of Antarctic pack ice. J. Phycol. 41:763-9.
Robinson, D. H., Arrigo, K. R., Kolber, Z., Gosselin, M. \& Sullivan, C. W. 1998. Photophysiological evidence of nutrient limitation of platelet ice algae in McMurdo Sound, Antarctica. J. Phycol. 34:788-97.

Robinson, D. H., Kolber, Z. \& Sullivan, C. W. 1997. Photophysiology and photoacclimation in surface sea ice algae from McMurdo Sound, Antarctica. Mar. Ecol. Prog. Ser. 147:243-56.

Ryan, K. G., Ralph, P. J. \& McMinn, A. 2004. Acclimation of Antarctic bottom-ice algal communities to lowered salinities during melting. Polar Biol. 27:679-86.

Smith, W. O. \& Nelson, D. M. 1985. Phytoplankton bloom produced by a receding ice edge in the Ross Sea: spatial coherence with the density field. Science 227:163-6.

Sudhir, P. \& Murthy, S. D. S. 2004. Review: effect of salt stress on basic processes of photosynthesis. Photosynthetica 42:481-6.

Vargo, G. A., Fanning, K., Heil, C. \& Bell, L. 1986. Growth rates and the salinity response of an Antarctic ice microflora community. Polar Biol. 5:241-7.

Xia, J., Li, Y. \& Zou, D. 2004. Effects of salinity stress on PSII in Ulva lactuca as probed by chlorophyll fluorescence measurements. Aquat. Bot. 80:129-37. 


\title{
Comparison of the microalgal community within fast ice at two sites along the Ross Sea coast, Antarctica
}

\author{
K.G. RYAN ${ }^{1 *}$, E.N. HEGSETH ${ }^{2}$, A. MARTIN ${ }^{1}$, S.K. DAVY ${ }^{1}$, R. O'TOOLE ${ }^{1}$, P.J. RALPH ${ }^{3}$, A. MCMINN ${ }^{4}$ and \\ C.J. THORN ${ }^{1}$ \\ ${ }^{1}$ Victoria University of Wellington, PO Box 600, Wellington, New Zealand \\ ${ }^{2}$ The Norwegian College of Fishery Science, University of Tromsø, 9037 Tromsø, Norway \\ ${ }^{3}$ Research Institute for Water and Environmental Resource Management, Department of Environmental Sciences, University of Technology, \\ Sydney, PO Box 123 Broadway, Sydney, NSW 2007, Australia \\ ${ }^{4}$ Institute of Antarctic and Southern Ocean Studies, University of Tasmania, Box 252-77 Hobart, TAS 7001, Australia \\ *Ken.Ryan@vuw.ac.nz
}

\begin{abstract}
Diverse microbial communities survive within the sea ice matrix and are integral to the energy base of the Southern Ocean. Here we describe initial findings of a four season survey (between 1999-2004) of community structure and biomass of microalgae within the sea ice and in the underlying water column at Cape Evans and Cape Hallett, in the Ross Sea, Antarctica as part of the Latitudinal Gradient Project. At Cape Evans, bottom-ice chlorophyll $a$ levels ranged from 4.4 to $173 \mathrm{mg} \mathrm{Chl} a \mathrm{~m}^{-2}$. Dominant species were Nitzschia stellata, N. lecointei, and Entomoneis kjellmanii, while the proportion of Berkeleya adeliensis increased steadily during spring. Despite being obtained later in the season, the Cape Hallett data show considerably lower standing stocks of chlorophyll ranging from 0.11 to $36.8 \mathrm{mg} \mathrm{Chl} a \mathrm{~m}^{-2}$. This difference was attributed to a strong current, which may have ablated much of the bottom ice biomass and provided biomass to the water below. This loss of algae from the bottom of the ice may explain why the ice community contributed only $2 \%$ of the standing stock in the total water column. Dominant species at Cape Hallett were Nitzschia stellata, Fragilariopsis curta and Cylindrotheca closterium. The low biomass at Cape Hallett and the prevalence of smaller-celled diatoms in the bottom ice community indicate that the ice here is more typical of pack ice than fast ice. Further data will allow us to quantify and model the extent to which ice-driven dynamics control the structure and function of the sea ice ecosystem and to assess its resilience to changing sea ice conditions.
\end{abstract}

Received 2 February 2006, accepted 12 June 2006

Key words: biomass, Cape Evans, Cape Hallett, Latitudinal Gradient Project, pack ice, primary production, Victoria Land

\section{Introduction}

Sea ice is a predominant feature of polar oceans and exerts a unique influence on Antarctic marine ecosystems. Although the sea ice that forms annually around the Antarctic continent represents a harsh physico-chemical environment with steep gradients in temperature, light, salinity, and nutrient concentrations (Arrigo \& Sullivan 1992, McMinn et al. 1999a), diverse microbial communities are able to survive in the brine inclusions and interstices of the sea ice matrix. Microalgae are a critical component of this community, and the sea ice provides a platform from which the algae can remain suspended in the upper ocean where light is sufficient for net growth (Arrigo \& Thomas 2004). The most prominent microalgae are pennate diatoms and efforts to investigate the biology of sea ice have focused on the composition, physiology and ecology of the species that dominate fast ice assemblages (e.g. Garrison 1991, Arrigo et al. 1998, McMinn et al. 2000, Thomas et al. 2001, Ryan et al. 2002, Trenerry et al. 2002) and which reach such concentrations that their photosynthetic pigments discolour the ice during the summer (Thomas \& Dieckmann 2002,
Mock \& Thomas 2005). The contribution of microalgae to primary production in ice-covered regions is thought to be between 10-30\% (Legendre et al. 1992, Arrigo et al. 1998). Biomass proxies such as chlorophyll $a(\mathrm{Chl} a)$ and particulate organic carbon and nitrogen are widely used measurements to characterize sea ice microbial communities and allow quantification of the microalgal biomass in sea ice or the water column.

In the Ross Sea, ice algal studies started in the 1980s, and the most extensively studied area is McMurdo Sound (Arrigo \& Thomas 2004). Some studies have also been undertaken further north at Terra Nova Bay (Stoecker et al. 1991, Buck et al. 1992, Palmisano \& Garrison 1993, Andreoli et al. 2000). The development, abundance and primary production of ice algae have been studied (Sullivan et al. 1982, 1985, Palmisano \& Sullivan 1983), and the effects of light perturbation on algal growth were included later (Palmisano et al. 1985, Grossi et al. 1987). Studies have been performed on algae in the platelet ice layer (Arrigo et al. 1993), and possible effects of UV radiation were assessed in the 1990s (Ryan \& Beaglehole 1994, 
McMinn 1997, McMinn et al. 1999a). Investigations of nutrient stress (McMinn et al. 1999b) and new methods for production studies have been introduced (McMinn \& Ashworth 1998, McMinn et al. 2000). However, relatively few studies have quantified community structure with respect to species or major taxa (Grossi \& Sullivan 1985, McMinn 1997, Garrison et al. 2005).

The Victoria Land mountain chain and coastline within the Ross Sea region contains the most extensive coastal gradient in Antarctica, which stretches from Cape Adare $\left(71^{\circ} \mathrm{S}\right)$ in the north, to the southern end of the Ross Ice Shelf $\left(86^{\circ} \mathrm{S}\right)$, and includes a variety of marine, terrestrial and freshwater habitats. Important environmental factors including solar radiation (annual radiation, UV radiation), temperature, day length and sea ice cover vary predictably along this gradient and are likely to exert a significant influence on ecological processes (Peterson \& HowardWilliams 2001, Howard-Williams et al. 2006). The Latitudinal Gradient Project (LGP) aims to develop an understanding of the ecosystems that exist along the Victoria Land coastline and to describe the potential environmental variability that may there occur in the future (Gordon 2003). Over the next 15 years, we will attempt to quantify the relationship between the extent of ice cover, local conditions, and total primary production along the icecovered Victoria Land coast and the findings may be used in future studies to develop scenarios of reduced ice at sites further south. In this paper, we describe initial findings of a four season survey (between 1999-2004) of biomass and

a.

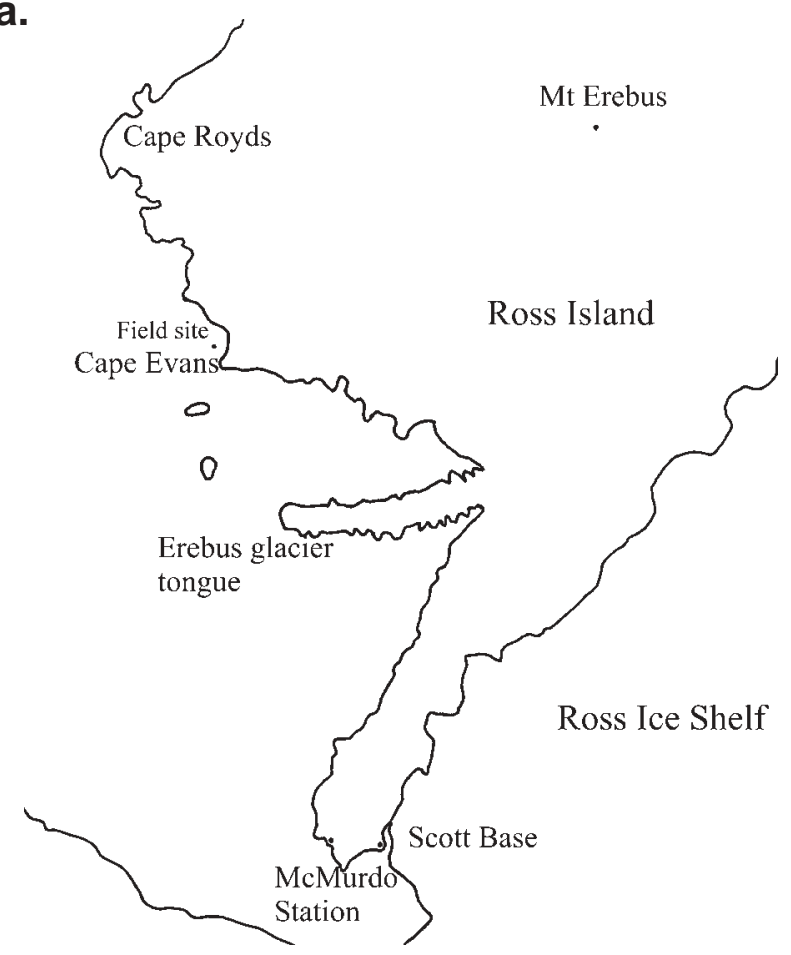

biodiversity at Cape Evans, Ross Island and Cape Hallett, Victoria Land, Antarctica. This study is the first under the LGP framework, to contrast microalgal community structure and biomass from these two most separated areas. We examine samples from within the sea ice and from the underlying water column in three ice types: the first year fast ice at Cape Evans and two-year and first year fast ice at Cape Hallett.

\section{Material and methods}

Sampling sites

Cape Evans, Ross Island $\left(77^{\circ} 38^{\prime} \mathrm{S}, 166^{\circ} 24^{\prime} \mathrm{E}\right.$, about $150 \mathrm{~m}$ from Scott's Hut, Fig. 1a): Samples of first year fast ice were collected every 3-4 days over a two week period from 28 October-12 November 1999, and again at the same location between 16 October-2 November 2001. The ice thickness was $1.9 \mathrm{~m}$ in 1999 and $2.1 \mathrm{~m}$ in 2001 and in both years there was minimal snow cover. In 1999 an additional site was sampled from the same ice formation but with $10 \mathrm{~cm}$ snow cover. The water current under the sea ice in both years was negligible. This site was chosen as no ice platelets were present on the underside of the sea ice.

Cape Hallett, Victoria Land $\left(72^{\circ} 19^{\prime} \mathrm{S}, 170^{\circ} 13^{\prime} \mathrm{E}\right.$, Fig. 1 b): Repeat samplings were done at each of four sites at intervals of 3-4 days from 19 November-12 December 2003, and from 14 November-2 December 2004. In the region around

b.

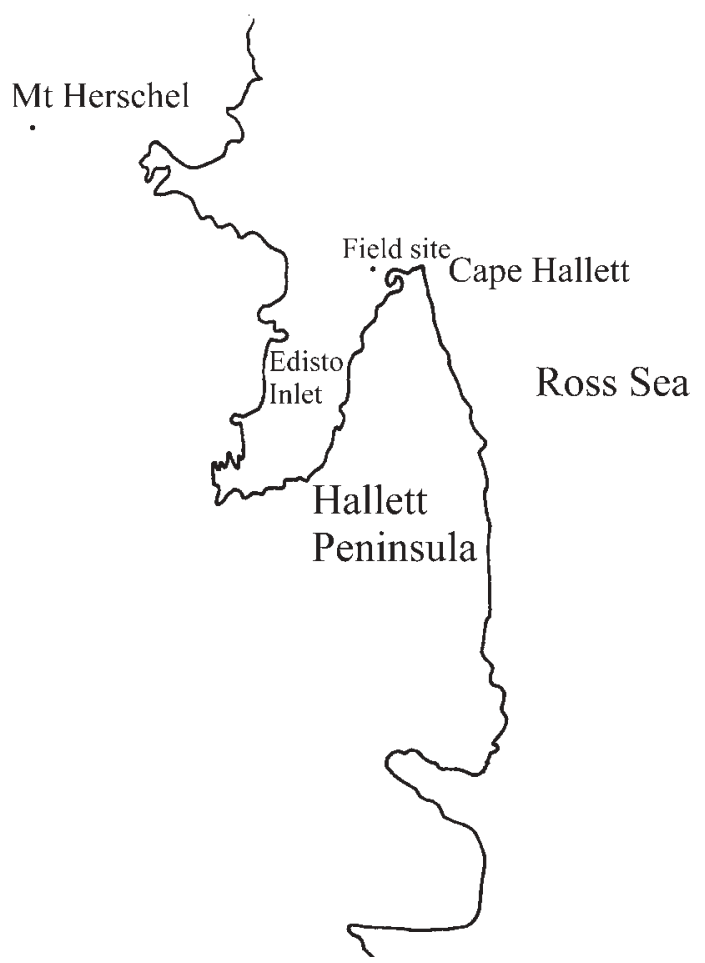

Fig. 1. Maps showing sampling sites at a. Cape Evans, and b. Cape Hallett. 

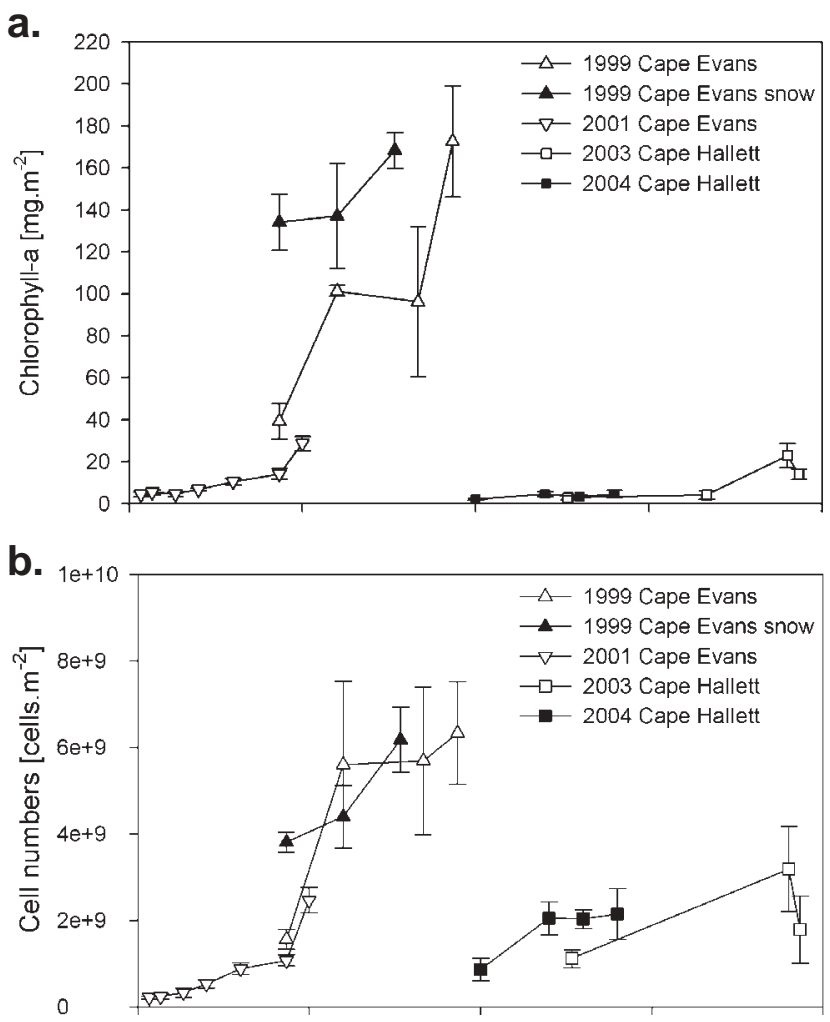

Fig. 2. Comparison of algal biomass measurements in the sea ice with respect to sampling date for Cape Evans (1999 and 2001) and Cape Hallett (2003 and 2004) for a. Chlorophyll a, b. cell numbers. Data are mean and standard error of the mean.

Seabee Hook, the ice ranged in thickness from 1.15 to $1.85 \mathrm{~m}$ in both years. The ice was two years old in 2003 and broke out at the end of the 2003/2004 season. New ice formed over winter 2004. Some old ice drifted into the region and became embedded in the new ice, but these regions were avoided in the 2004 collections. The samples collected over 2003 and 2004 in the same region therefore provide us with data from first year sea ice and from twoyear-old ice. An additional physical factor governing ice conditions was the presence of a strong current in the water under the ice. The direction and strength of this current was unpredictable and appeared to result from an eddy forming in Edisto Inlet in a current running south to north along the main coastline. This current appeared very strong in 2003 although it was not measured. Icebergs embedded in the sea ice may have modulated its flow and direction. In 2004 the current was less and was not as variable as in the previous year, perhaps due to the fact that there were less icebergs embedded in the ice. The current caused scouring of the under surface of the ice in both years.

\section{Ice cores}

Sea ice algae were collected from $130 \mathrm{~mm}$ diameter cores cut from the bottom of sea ice at several locations using a
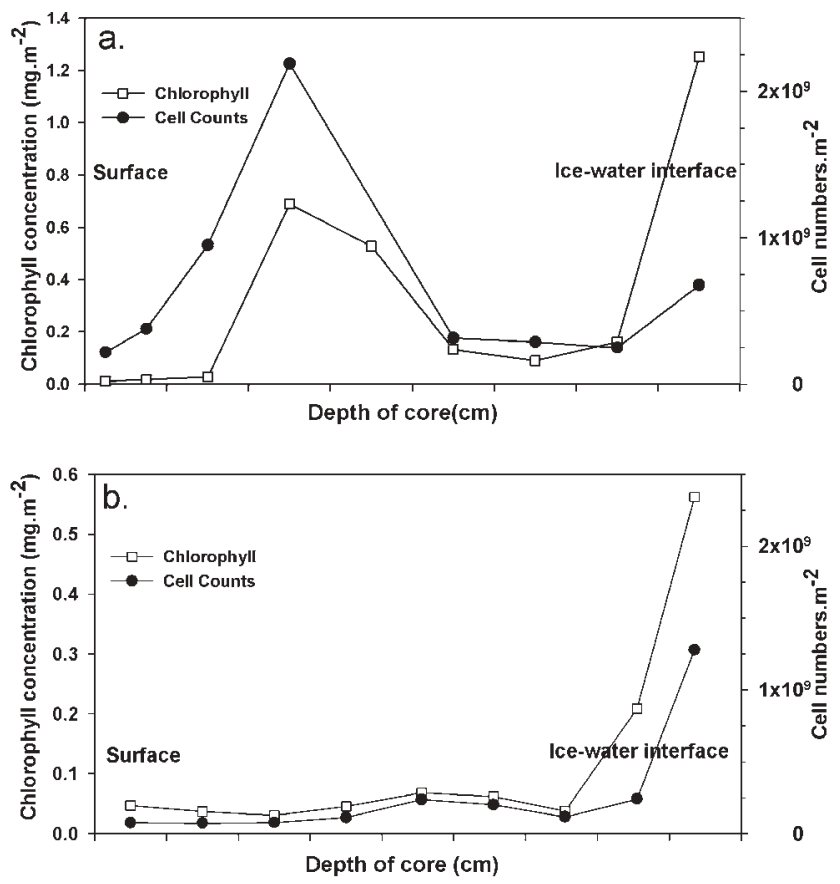

Fig. 3. Chlorophyll concentrations and microalgal cell counts with respect to sea ice profile depth for an individual core extracted from Cape Hallett in a. 2003, and b. 2004.

Kovaks (Kovaks, USA) ice corer. As far as possible these sites represented the range of conditions of sea ice in the region. Four to five sites were chosen that were typical of the fast ice in the region in terms of snow cover and ice thickness. Samplings were done in the centre of an ice formation that was at least $100 \mathrm{~m}$ across. With the exception of one site at Cape Evans in 1999, all sites were clear of snow. At Cape Evans 15 cores were sampled from clear ice in 1999 (3-5 replicates, 4 time points), and seven in ice with $10 \mathrm{~cm}$ snow cover (2-3 replicates, 3 time points). In 2001 36 cores were sampled from clear ice $(n=4-6$, seven time points). The 2003 sampling programme at Cape Hallett consisted of 49 cores from different locations near Sea Bee Hook. Of these, 16 cores were taken from the same location ( $1.5 \mathrm{~m}$ ice, no snow cover) at intervals over the period of the study as representative of the Cape Hallett region ( $n=4,4$ time points). In 2004, 53 cores were collected from different locations over the period of the study. Of these, 16 cores ( $n=4,4$ time points) were from the same snow free location ( $1.35 \mathrm{~m}$ ice) were again chosen as representative of the region.

During collection, the cores were protected from light damage by performing all operations underneath a black sheet and transferring the cores into black plastic tubes. Cores were then cut into 10 or $20 \mathrm{~cm}$ sections to a standard size (usually $40 \times 40 \times 100 \mathrm{~mm}$ ). Each section was then melted into three times the quantity of filtered seawater $\left(35 \%, 0.22 \mu \mathrm{m},-1.8^{\circ} \mathrm{C}\right)$ under low-light $(<1 \mu \mathrm{mol}$ photons 
a.

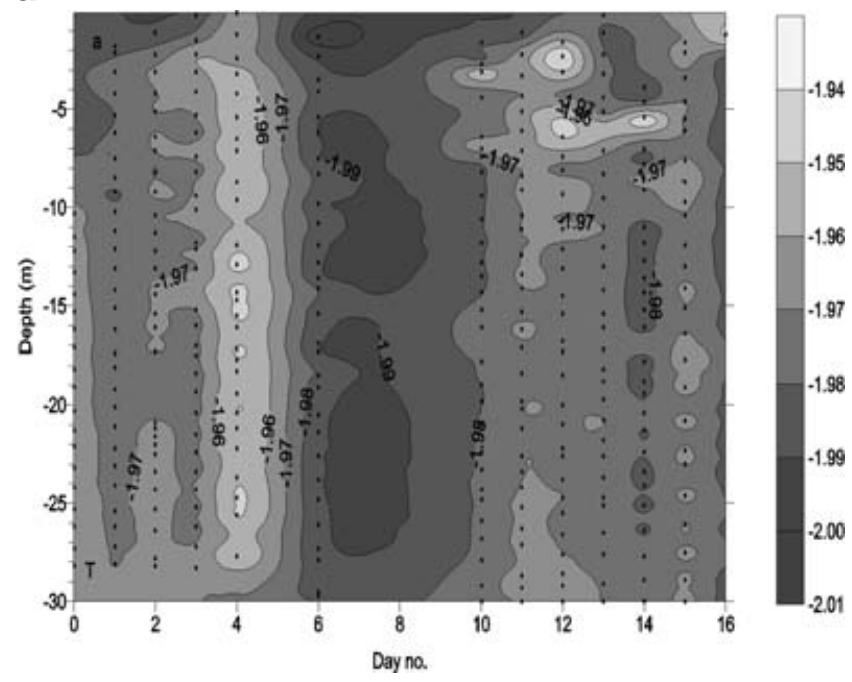

b.

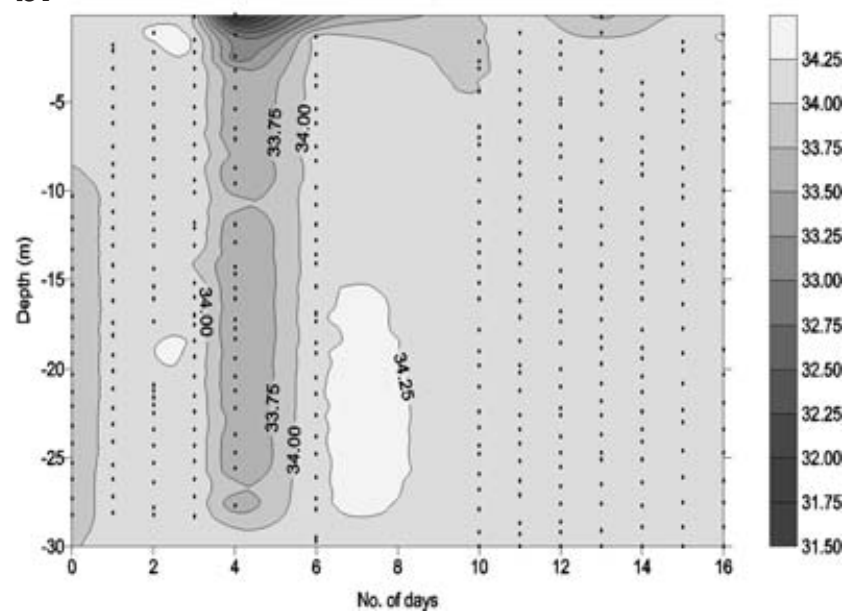

C.

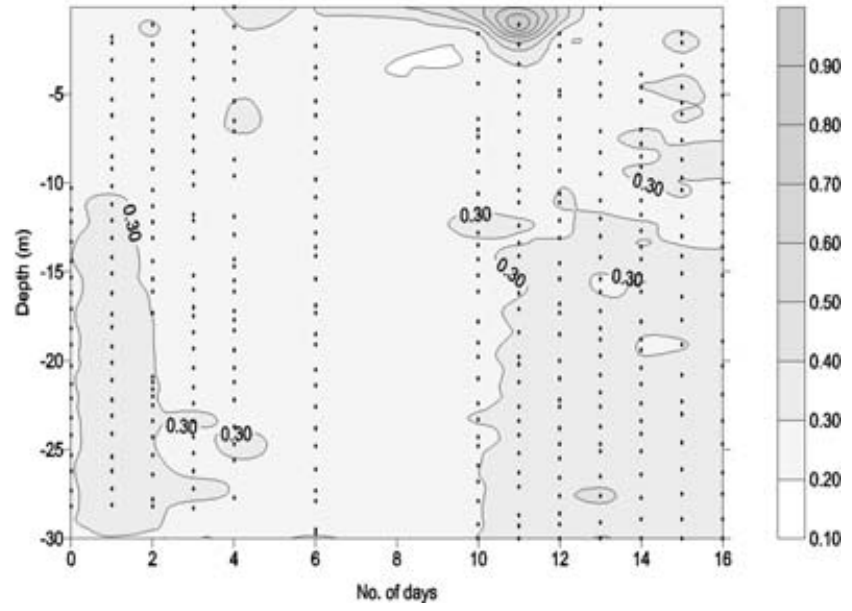

Fig. 4. Composite contour images of CTD (conductivity, temperature, depth) casts (dotted lines) deployed under the ice to a depth of $30 \mathrm{~m}$ at Cape Evans between 18 October and 3 November 2001 showing a. temperature, b. salinity, c. Chl $a$. a.

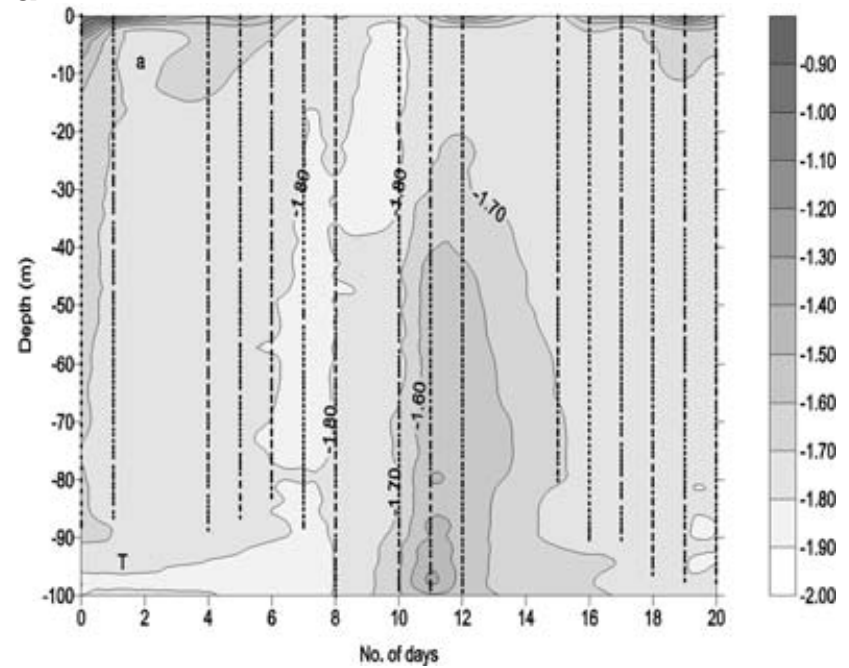

b.

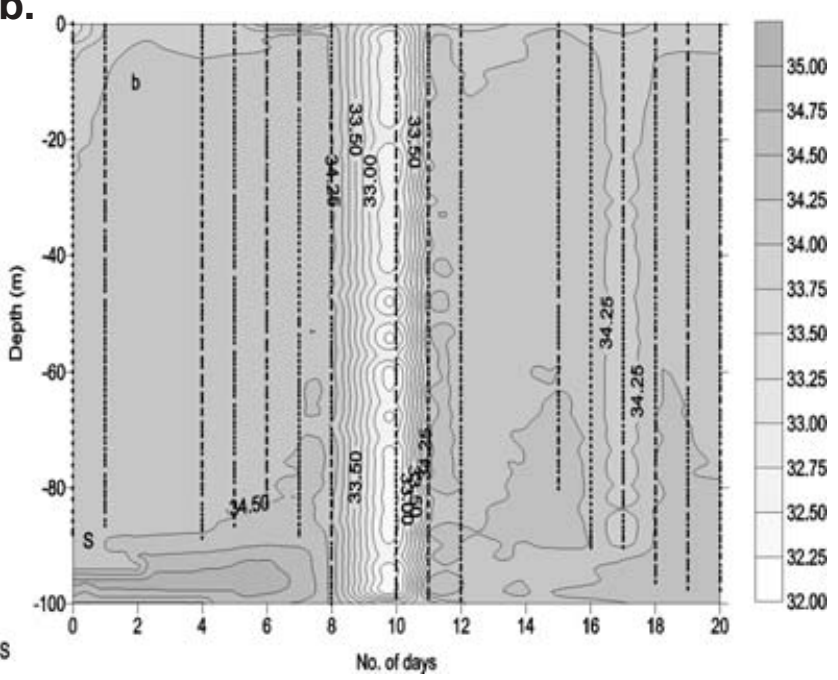

C.

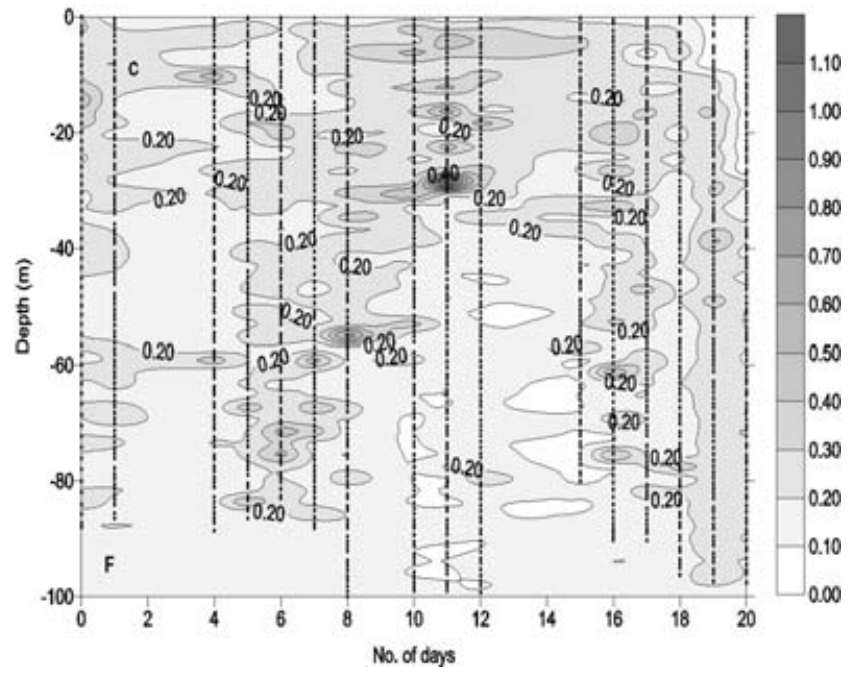

Fig. 5. Composite contour images of CTD casts (dotted lines) deployed under the ice to a depth of $100 \mathrm{~m}$ at Cape Hallett between 15 November and 5 December 2004 showing a. temperature, b. salinity, c. Chl $a$. 
$\mathrm{m}^{-2} \mathrm{~s}^{-1}$ ) over a period of 12 hours (following the procedures in Ryan et al. 2002, 2004). After melting, the sample was divided into subsamples and analysed for Chl $a$ and the species present were identified and counted

\section{Surface brine sampling}

Algae growing within the brine channels near the surface of the sea ice were collected at Cape Hallett. A shallow hole $20 \mathrm{~cm}$ diameter and $20 \mathrm{~cm}$ deep was drilled in the surface of the ice with a powered ice auger. The hole was immediately covered with a black sheet and left for 10-15 min. After this time, the brine that had drained into the hole from the surrounding ice was collected into opaque containers, and maintained at $0^{\circ} \mathrm{C}$ until use. At all times during sampling, light shock was avoided by performing all operations under the black sheet.

\section{CTD profiles}

A conductivity, temperature, depth (CTD) profiling instrument was used at Cape Evans (Applied Microsystems Ltd, Model STD-12 Plus, with attached Chl $a$ flurometer, Wetstar model no: 9706013) and at Cape Hallett (RBR Instruments with an attached $\mathrm{Chl} a$ fluorometer). Profiles were conducted at each location by lowering the instrument through a $400 \mathrm{~mm}$ hole in the ice to the bottom (30 m, Cape Evans) or to $100 \mathrm{~m}$ (Cape Hallett). Depth zero on the CTD plots (Figs $4 \& 5$ ) refer to the surface of the water in the hole. The water depth at the Cape Hallett site was c. $150 \mathrm{~m}$. Profiles were performed each day through the same hole for the duration of each field season unless logistics prevented their collection. At Cape Evans the casts were made at solar noon (approximately 1:30 pm local time at this longitude), and a similar collection regime was attempted at Cape Hallett but the distance of the profile site from our field camp often prevented a solar noon collection. Recorded depth-time data were analysed using Surfer for Windows, v6, software. Although the instrument was lowered to the full $100 \mathrm{~m}$ of cable at Cape Hallett, the actual depth achieved was usually less than this as the strong current drove the instrument sideways and therefore to a lesser depth.

\section{Chlorophyll a determinations}

100-300 $\mathrm{ml}$ samples of the melted core section were filtered onto $47 \mathrm{~mm} \mathrm{GF} / \mathrm{F}$ filters and extracted in $10 \mathrm{ml}$ of methanol over 12 hours in the dark at $4^{\circ} \mathrm{C}$. The Chl $a$ concentration was measured on a digital fluorometer (Turner $10 \mathrm{AU}$ ) using the acidification protocol of Evans et al. (1987).

\section{Cell density and identifications}

A $10 \mathrm{ml}$ sample of each core section was fixed in $0.5 \%$ glutaraldehyde and returned to New Zealand for analysis of cell density and for species identifications. A $0.5 \mathrm{ml}$ aliquot of this material was counted on an inverted microscope (Zeiss) using a special settling chamber and phase contrast optics until a minimum of 200 cells per sample were identified and counted. Live samples of the Cape Evans material were examined in the field on an upright microscope (Kyowa) using standard microscope slide preparations for species identifications. Fixed samples were retained and returned to New Zealand for total cell counts as described above.

\section{Phytoplankton sampling}

Water samples for phytoplankton were collected with a water bottle lowered through the same hole as for the CTD measurements and closed by a messenger weight at 5,25 and $50 \mathrm{~m}$. Samples were split for Chl $a$ analysis and for species identification and cell numbers. The cells were fixed with $0.5 \%$ glutaraldehyde and counted as for the sea ice cores and a minimum of 100 cells were counted. Chlorophyll $a$ was measured after filtering $300 \mathrm{ml}$ seawater, then analysed as described above for ice cores. Data were compared using Student's t-test.

\section{Results}

Ice cores

In 1999 and 2001 all of the ice cores at Cape Evans consisted of congelation ice, and no platelet ice was observed at the bottom. The ice was first year ice, with no snow cover, $1.9 \mathrm{~m}$ thick in 1999 and $2.1 \mathrm{~m}$ thick in 2001. This ice was clear of snow cover for at least one month before our visits in both years. In an additional site in 1999, the ice had a snow cover of approximately $10 \mathrm{~cm}$. At Cape Hallett all ice cores in both years consisted of congelation ice, with no platelet ice observed at the bottom. In 2003 the ice was approximately $1.5 \mathrm{~m}$ thick multi-year ice, while in 2004 it was of similar thickness but was first year ice. All sites chosen for study at Cape Hallett were clear of snow cover and remained so throughout our field season. The Cape Hallett sampling areas were in a similar condition, for at least one week prior to our study in each year.

\section{Physical conditions in the water column beneath the ice}

Cape Evans 2001: During the period of measurement, the water mass beneath the ice had a salinity of between 33.7 and $34.2 \%$ and a temperature of -1.95 to $-1.99^{\circ} \mathrm{C}$. Fluctuations in water salinity and temperature were minor and the water masses remained similar for the duration of the experiment (Fig. 4a \& b). Water currents under the sea ice were negligible.

Cape Hallett 2004: Compared to Cape Evans, the water 
mass at Cape Hallett beneath the ice had a slightly higher salinity, ranging between 34.2 and $34.4 \%$, and the temperature was slightly warmer at -1.5 to $-1.8^{\circ} \mathrm{C}$ during most of the period of study, with only minor fluctuations with time. An influx of warmer, low salinity water took place after about day 10 (25 November) of the sampling period (Fig. 5a \& b). This water mass was detected from the surface to a depth of $100 \mathrm{~m}$ and may have flushed some of the biomass from the inlet, particularly at depth.

\section{Sea ice algal biomass}

Cape Evans: The bottom surface of the ice was covered in a dense layer of algal cells, with some cells of Berkelya adeliensis suspended beneath the ice in the latter part of the collection period in 1999. No platelet ice was present in either year. In 1999 the snow-covered site had Chl $a$ concentrations varying from 134 to $168 \mathrm{mg} \mathrm{Chl} a \mathrm{~m}^{-2}$ as the season progressed. Areal $\mathrm{Chl} a$ concentrations in the clear ice site increased from $34 \mathrm{mg}$ to $173 \mathrm{mg} \mathrm{Chl} a \mathrm{~m}^{-2}$ (Fig. 2a), in the bottom section of the ice core $(P<0.01)$. The snow and clear site chlorophyll levels were not significantly different when compared on similar days $(P<0.05)$, with the exception of the earliest snow covered measurement $(P<0.05)$. Cell numbers in both types of ice were similar, ranging from 1.6 to $6.3 \times 10^{9}$ cells $\mathrm{m}^{-2}$ (Fig. $2 \mathrm{~b}$ ), and the increase over the season in the clear site was significant $(P<0.01)$.

In 2001 areal Chl $a$ concentrations increased over the collection period from a minimum of $4.4 \mathrm{mg} \mathrm{Chl} a \mathrm{~m}^{-2}$ to a maximum of $28.7 \mathrm{mg} \mathrm{Chl} a \mathrm{~m}^{-2}$ for the 36 cores $(P<0.001)$ (Fig. 2a). Total cell numbers per core increased over an order of magnitude during the season in 2001 from $0.21-2.5$ x $10^{9}(P<0.001)$ (Fig. 2b). The majority of the algae were found in the bottom layer, although this was only assessed visually as no profile cores were taken.

Cape Hallett: The bottom surface of the ice was smooth and eroded, with no platelets attached. Algal cells present were embedded in the ice and there were no algae suspended beneath the ice as was found in the later part of the season at Cape Evans. Areal Chl $a$ concentrations in annual ice in 2003 increased significantly during the period of measurements from a minimum of 2.9 to a maximum of $22.9 \mathrm{mg} \mathrm{Chl} \mathrm{a} \mathrm{m}^{-2}(P<0.01)$ (Fig. 2a), however the increase in cell number from 1.1 to $1.8 \times 10^{9}$ cells $\mathrm{m}^{-2}$ (Fig. 2b) was not significant. The highest concentration of Chl $a$ was evident at the ice water interface, but there was a substantial peak of chlorophyll, at about $50 \mathrm{~cm}$ from the surface of this core (Fig. 3a), indicating that this ice was two seasons old. This was also evident in the cell counts, where the number of cells in the middle of the core was actually higher than at the ice water interface. Depth integrated areal $\mathrm{Chl} a$ concentrations, calculated on four profiles from similar ice taken early in the sampling period, were $2.1 \pm 0.7 \mathrm{mg} \mathrm{m}^{-2}$ (mean \pm standard error). On a volume basis this equated to $1.4 \pm 0.4 \mathrm{mg} \mathrm{m}^{-3}$. The percentage of Chl $a$ in the bottom $10 \mathrm{~cm}$ of these profiles was $18.4 \pm 3.2 \%$.

In 2004, the areal Chl $a$ concentration varied from a minimum of $2.1 \mathrm{mg} \mathrm{Chl} a \mathrm{~m}^{-2}$ to a maximum of $4.6 \mathrm{mg}$ Chl $a \mathrm{~m}^{-2}$ (Fig. 2a). This small increase over the period of study was not significant. In the same samples the change in cell numbers from 0.9 to $2.1 \times 10^{9}$ also was not significant (Fig. 2b). The profile from the 2004 ice cores (Fig. 3b) illustrates annual fast ice as there was no peak in chlorophyll or cell numbers mid way through the ice core. Depth integrated areal Chl $a$ concentrations based on three similar profiles was $2.7 \pm 0.6 \mathrm{mg} \mathrm{m}^{-2}$ or $2.1 \pm 0.6 \mathrm{mg} \mathrm{m}^{-3}$.

Table I. Percentage species composition, Cape Evans 1999 mean (standard error).

\begin{tabular}{|c|c|c|c|c|c|c|c|c|c|c|}
\hline Snow & $28 \mathrm{Oct}$ & 5 & $3.5(1.2)$ & 29.7 (3.9) & $6.94(1.4)$ & $6.3(0.6)$ & $14.9(1.5)$ & $32.2(3.0)$ & $2.3(0.4)$ & $4.2(0.8)$ \\
\hline \multirow{3}{*}{ Clear ice } & $3 \mathrm{Nov}$ & 2 & $17.1(13.9)$ & $24.2(6.6)$ & $9.0(2.6)$ & $3.8(0.9)$ & $15.7(5.7)$ & $26.7(2.6)$ & $0.1(0.1)$ & $3.5(0.7)$ \\
\hline & $9 \mathrm{Nov}$ & 3 & $29.2(12.4)$ & $13.0(2.9)$ & $9.2(2.6)$ & $4.0(1.3)$ & $28.8(6.2)$ & $11.8(2.5)$ & $0.3(0.2)$ & $3.8(1.5)$ \\
\hline & $12 \mathrm{Nov}$ & 4 & $22.7(3.7)$ & $14.8(1.7)$ & $8.9(1.7)$ & $4.5(0.5)$ & 28.9 (4.4) & $16.9(2.7)$ & $0.2(0.0)$ & $3.1(0.3)$ \\
\hline
\end{tabular}

Table II. Percentage species composition, Cape Evans 2001 mean (standard error).

\begin{tabular}{|c|c|c|c|c|c|c|c|c|c|c|}
\hline & & $\mathrm{n}$ & $\begin{array}{l}\text { Berkeleya } \\
\text { adeliensis }\end{array}$ & $\begin{array}{l}\text { Entomoneis } \\
\text { kjellmannii }\end{array}$ & $\begin{array}{l}\text { Fragilariopsis } \\
\text { curta }\end{array}$ & $\begin{array}{c}\text { Navicula } \\
\text { glaciei }\end{array}$ & $\begin{array}{l}\text { Nitzschia } \\
\text { lecointei }\end{array}$ & $\begin{array}{l}\text { Nitzschia } \\
\text { stellata }\end{array}$ & $\begin{array}{c}\text { Pleurosigma } \\
\text { solinarum }\end{array}$ & Other \\
\hline \multirow[t]{5}{*}{ Clear ice } & 19 Oct & 4 & 0.0 & $32.4(6.0)$ & $23.1(13.8)$ & $17.3(4.6)$ & $0.6(0.4)$ & $14.5(4.0)$ & $1.6(0.7)$ & $10.6(1.8)$ \\
\hline & $24 \mathrm{Oct}$ & 4 & $0.4(0.4)$ & $32.1(8.4)$ & $24.2(10.3)$ & $13.0(2.8)$ & $1.7(0.6)$ & $14.3(5.5)$ & $2.2(0.7)$ & $12.4(3.6)$ \\
\hline & 28 Oct & 4 & 0.0 & $34.0(3.5)$ & $6.2(3.8)$ & $21.4(2.6)$ & $3.3(0.8)$ & $16.4(4.0)$ & $1.9(0.6)$ & $12.8(2.8)$ \\
\hline & $30 \mathrm{Oct}$ & 4 & $0.1(0.1)$ & $40.8(8.2)$ & $10.9(1.5)$ & $16.5(2.1)$ & $3.6(1.8)$ & $16.6(2.1)$ & $1.8(0.4)$ & $9.9(1.4)$ \\
\hline & $2 \mathrm{Nov}$ & 4 & $0.0)$ & $31.5(2.4)$ & $8.1(2.4)$ & $22.2(3.8)$ & $5.0(1.5)$ & $24.5(4.2)$ & $2.1(0.7)$ & $7.7(2.6)$ \\
\hline
\end{tabular}


The percentage of Chl $a$ in the bottom $10 \mathrm{~cm}$ of these profiles was $36.5 \pm 13.5 \%$. The presence of multiyear ice in 2003 did not significantly alter the Chl $a$ content of the bottom ice as yields were similar in different years at the same time of the year. However, as is readily seen in Fig. 2a, Chl $a$ levels in Cape Hallett are approximately two orders of magnitude lower that at an equivalent time of the year at Cape Evans $(P<0.001)$.

\section{Ice algal species compositions}

Microscopic examination of the algal samples showed that different species compositions existed in the two different locations (Tables I-IV). At Cape Evans in 1999 the bottom ice community under clear ice was a mixture of pennate diatoms including Nitzschia stellata Manguin, Nitzschia lecointei Van Heurck, Entomoneis kjellmanii (Cleve) and to a lesser extent also Fragilariopsis curta (van Heurck) Hustedt. Berkeleya adeliensis Medlin was present as threads hanging off the bottom surface of the sea ice, and this species increased in concentration over the two week period in early November1999 (Table 1). In a separate set of collections, species compositions were determined for a $10 \mathrm{~cm}$ snow covered region of sea ice from the same formation at Cape Evans. As can be seen in Table I, the species composition in this region was very similar to the adjacent snow free plot. In 2001 the collections were taken approximately two weeks earlier than in 1999 (Table II). The species composition observed at the end of this period closely resembled that at the start of the 1999 collections (compare similar dates in Tables I \& II).

At Cape Hallett, the algal communities from the bottom of the ice and from the surface brine were examined. Pennate diatoms dominated the species composition of the bottom ice algal communities in each year, with $N$. stellata, F. curta, and Cylindrotheca closterium (Ehrenberg) typically comprizing more than $50 \%$ of all samples. In 2003, the most abundant species was F. curta (Table III). In 2004 the same three species dominated, although the a.

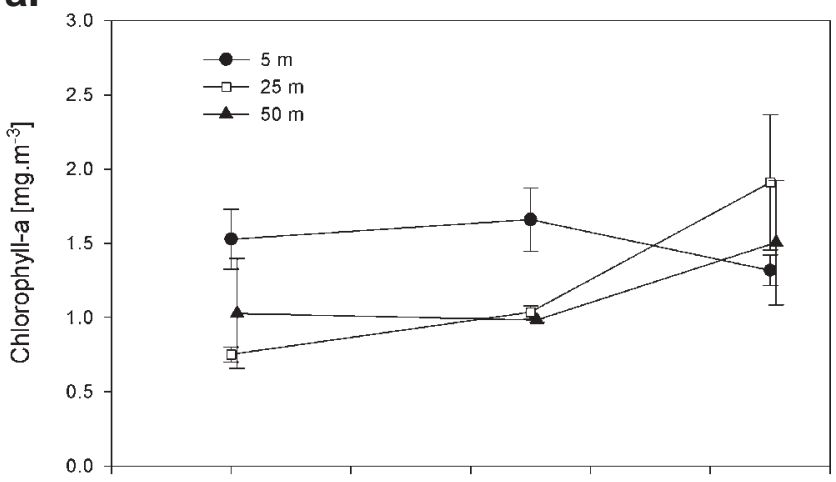

b.

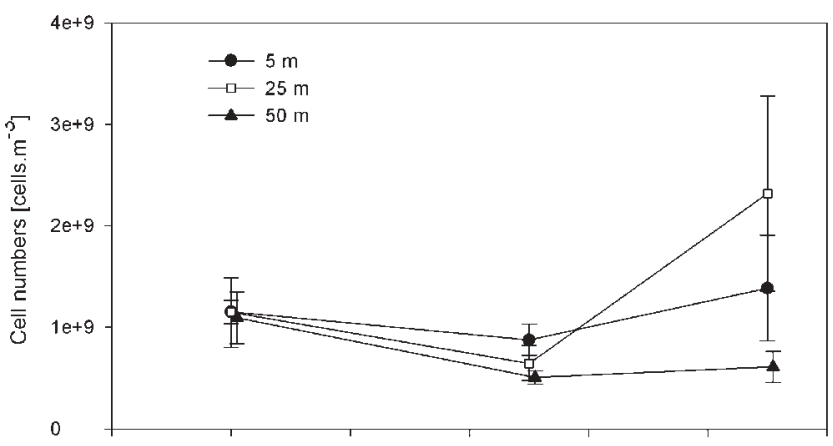

Fig. 6. Chlorophyll concentrations and cell counts of phytoplankton sampled from deployments to 5,25 , and $50 \mathrm{~m}$ under annual sea-ice between 20 November and 2 December 2004 at Cape Hallett, a. Chl $a$, b. cell counts. Data are mean and standard error of the mean.

relative proportions changed, and $N$. stellata became the most abundant species (Table IV). Other species abundant at Cape Evans were either not found at all (B. adeliensis) or were present in very low concentrations (E. kjellmanii). Samples were also analysed from brine extracted from the surface of the sea ice. The species composition here was quite different, and was dominated by F. curta, Chaetoceros sp. and the dinoflagellate Polarella glacialis Montresor, Procaccani \& Stoecker. In 2004, P. glacialis was especially

Table III. Percentage species composition, Cape Hallett 2003 mean (standard error).

\begin{tabular}{lcccccrrrr}
\hline & $n$ & Chaetoceros sp. & Cylindrotheca spp & $\begin{array}{c}\text { Fragilariopsis } \\
\text { curta }\end{array}$ & $\begin{array}{c}\text { Navicula } \\
\text { glaciei }\end{array}$ & $\begin{array}{r}\text { Nitzschia } \\
\text { lecointei }\end{array}$ & $\begin{array}{c}\text { Nitzschia } \\
\text { stellata }\end{array}$ & Polarella sp & Other \\
\hline Bottom ice & 3 & 0.0 & $29.0(25.3)$ & $43.1(18.7)$ & $1.1(1.1)$ & $4.1(2.4)$ & $11.2(6.4)$ & $5.8(5.8)$ & $11.1(3.5)$ \\
Surface ice & 2 & $0.4(0.4)$ & $12.0(2.0)$ & $32.3(7.7)$ & $4.4(1.0)$ & $10.5(3.5)$ & $7.1(1.0)$ & $10.7(3.9)$ & $22.7(8.8)$ \\
\hline
\end{tabular}

Table IV. Percentage species composition, Cape Hallett 2004 mean (standard error).

\begin{tabular}{lccccccrrr}
\hline & $\mathrm{n}$ & Chaetoceros sp. & Cylindrotheca spp & $\begin{array}{c}\text { Fragilariopsis } \\
\text { curta }\end{array}$ & $\begin{array}{c}\text { Navicula } \\
\text { glaciei }\end{array}$ & $\begin{array}{r}\text { Nitzschia } \\
\text { lecointei }\end{array}$ & $\begin{array}{c}\text { Nitzschia } \\
\text { stellata }\end{array}$ & $\begin{array}{c}\text { Polarella sp } \\
\text { Other }\end{array}$ \\
\hline Bottom ice & 3 & 0.0 & $9.6(2.5)$ & $25.0(5.2)$ & 0.0 & $6.1(2.5)$ & $55.9(5.4)$ & 0.0 & $3.5(2.6)$ \\
Surface ice & 3 & $21.7(5.11)$ & $1.0(0.6)$ & $12.3(0.4)$ & 0.0 & 0.0 & $0.9(0.5)$ & $56.5(7.8)$ & $7.5(3.1)$ \\
Seawater $(5 \mathrm{~m})$ & 2 & $0.1(0.1)$ & $16.9(5.0)$ & $33.9(9.4)$ & 0.0 & $0.4(0.4)$ & $15.2(3.9)$ & $0.3(0.3)$ & $26.5(5.8)$ \\
\hline
\end{tabular}


abundant. All other species were present in low concentrations (Table IV).

\section{Phytoplankton in the water column}

Cape Evans 2001: Phytoplankton samples were not taken, hence we do not know whether growth had started in the water column below the ice. Increased biomass just below the ice, evident in the CTD profiles (Fig. 4c) late in the period, was probably due to ice algae falling off the ice during sampling the evening before. A slightly higher biomass could be seen in the deepest $15-20 \mathrm{~m}$ in the beginning and end of the sampling period. This elevated biomass rising from the bottom was most probably due to re-suspension of bottom sediments containing algal cells.

Cape Hallett 2004: The species composition in the water column was similar to that in the bottom ice, although the proportion of $N$. stellata was less (Table IV). Phaeocystis sp. was sometimes present in seawater samples but this was rare. The degree of chlorophyll present in the water column at the time of the first CTD cast (15 November) suggests that algal biomass was already present beneath the ice (Fig. 5c). Both chlorophyll and cell numbers (expressed in volumetric rather than areal units) are given in Fig. 6 for water bottle samples collected at three different depths on 22 November 2004. These data show that algae were present through the water column at approximately the same concentrations regardless of depth (1-1.5 $\left.\mathrm{mg} \mathrm{Chl} a \mathrm{~m}^{-3}\right)$. Comparison with the data from a CTD cast made on the same day (Fig. 5c) allows a rough calibration of the fluorescence reading on the CTD instrument at approximately 1 fluorescence unit $=5.7 \mathrm{mg} \mathrm{Chl} a \mathrm{~m}^{3}$. Integrating the fluorescence profile for 22 November 2004 for the full $100 \mathrm{~m}$ gives 20.4 fluorescence units, or approximately $115 \mathrm{mg} \mathrm{Chl} a$ for one square metre of the water column. The depth integrated volumetric data from the profiles in Fig. 3c at a similar collection time show $2 \mathrm{mg}$ in a square metre of $1.6 \mathrm{~m}$ thick ice. These calculations indicate that sea ice contains approximately $2 \%$ of the biomass in the total ice/water column on 22 November 2004.

\section{Discussion}

McMurdo Sound in the Ross Sea is an area where sea ice algae have been extensively studied over a period of 25 years. Despite this there is little known of their composition and inter-annual variability in relation to physical conditions of the ice matrix. This study has compared sea ice algal communities in a well-known area of the southern Ross Sea with those in a much lesser known part of the northern Ross Sea. To our knowledge this is the first report of the sea ice algal community at Cape Hallett. The ice at the two locations was of variable age. At Cape Evans, both in 1999 and 2001, annual fast ice c. $2.0 \mathrm{~m}$ thick covered the study area after breakout of the ice in the previous January. At Cape Hallett, satellite data collected from 1979 to 2000 suggest that sea ice generally remains in Edisto Inlet after the rest of the ice along the coast from Cape Adare to Coulman Island has broken out. The average date that icefree water eventually appears in Edisto Inlet is January $27 \pm$ two weeks (SD), and while on average this ice-free period extends until 2 March, in some years the ice does not completely clear at all (Falconer \& Pyne 2000). This appears to have been the case in 2003, as the ice in Edisto Inlet in late spring of this year was multiyear ice, with numerous trapped icebergs. The ice broke out in January 2004 , and as a result there was first year ice for our study in late 2004.

A number of authors have investigated the water current systems in McMurdo Sound and circulation patterns are generally considered complex and variable (Gilmore 1963, Heath 1977). Several processes interact to control the currents within and around the Sound with wind and tidal activity being the most significant, leading to currents highly variable in time and space (Heath 1977, Barry \& Dayton 1988). The Cape Evans sampling site was in the lee of the prevailing currents in McMurdo Sound and the currents in the study area were negligible in both years. This site was chosen to avoid platelet ice cover on the underside of the ice as it is difficult to collect samples from plateletcovered sea ice by ice corer without losing biomass.

Further north, the currents of water masses entering the Ross Sea in a west-north-west direction over the shelf are intensified in front of Victoria Land due to the narrowing of the continental shelf and typical current flows of $8-8.5 \mathrm{~m} \mathrm{~s}^{-1}$ are higher than elsewhere in the Ross Sea (Picco et al. 1999). Tidal currents are also very strong in this area (Johnson \& van Woert 2006). Hence the hydrographical conditions at our two sampling sites at Cape Evans and Cape Hallet were quite different with regard to water currents, and this had a significant effect on ice algal abundance.

\section{Ice algal biomass}

Arrigo et al. (2003) compiled a detailed survey of the pack ice algal communities in the Ross Sea. They reported mean $\mathrm{Chl} a$ abundances in the Ross Sea of $2.53 \mathrm{mg} \mathrm{Chl} a \mathrm{~m}^{-2}$. We have noted similar levels in pack ice on the outer coast west of the Ross Sea in the vicinity of the Mertz glacier $(2.08 \mathrm{mg}$ Chl $a \mathrm{~m}^{-2}$, McMinn et al. in press). Arrigo et al. (2003) noted that these levels are lower than those measured in other pack ice habitats particularly in the Weddell Sea. Standing crops in fast ice in the Ross Sea are typically much higher than in pack ice at around $200 \mathrm{mg}$ Chl $a \mathrm{~m}^{-2}$ (Palmisano \& Sullivan 1983, Arrigo et al. 1998), and levels can rise considerably higher than this (e.g. $1.9{\mathrm{~g} \mathrm{Chl} a \mathrm{~m}^{-2}}^{-2}$ has been recorded in fast ice on the west coast of the Ross 
Sea by Riaux-Gobin et al. 2003). We confirm typical McMurdo Sound levels in the bottom $10 \mathrm{~cm}$ of fast ice at Cape Evans, where levels rose to $173 \mathrm{mg} \mathrm{Chl} a \mathrm{~m}^{-2}$ in mid November of 1999. The lower biomass measured in 2001 is most probably due to the earlier sampling period (Fig. 2a).

At a similar time of the year at Cape Hallett (mid November), the standing crop of bottom ice Chl $a$ was only $0.1 \mathrm{mg} \mathrm{Chl} a \mathrm{~m}^{-2}$. One month later on 15 December, the Chl $a$ content at Cape Hallett had still reached only one fifth that at Cape Evans one month earlier in the season (36.8 mg. Chl $a \mathrm{~m}^{-2}$ ).

The snow cover was minimal at both study sites, but the ice thickness was less at Cape Hallett (1.5 m vs $2 \mathrm{~m}$ at Cape Evans). The huge difference in $\mathrm{Chl} a$ standing stocks at the two locations is unlikely to be due to differences in ice thickness or age (Arrigo et al. 2003), and is more likely to be due to local conditions. The start of the 2001 sampling at Cape Evans yielded low biomass, and biomass increased steadily through the season. Losses of biomass were not observed in the period of the study, however, it should be noted that strong reductions in biomass late in the season have been observed at Cape Evans in previous years (McMinn et al. 2000). At Cape Evans the water current beneath the ice was typically very low, to non existent, while at Cape Hallett currents were very strong. The Chl $a$ profiles obtained from Cape Hallett in 2004 are typical of annual fast ice floes where the biomass is concentrated in the bottom 20-30 cm of the ice. In 2003, a peak in Chl a levels and cell counts in the middle of the profiles indicated two year ice (Fig. 3a). However, in both years the total chlorophyll biomass was low, both in annual and in twoyear old fast ice. These biomasses are similar to those recorded one month earlier in the season at Cape Evans. There was no significant interannual variability in overall biomass between 2003 and 2004 at Cape Hallett. In 2004 there was no significant increase in biomass during the period of sampling, while in 2003, levels only increased in the last two samplings just prior to the breakup of the ice. Sampling at Cape Hallett was performed later in the season than at Cape Evans, and we cannot rule out the possibility that an ice algal peak may have occurred at Cape Hallett before sampling started. The underside of the ice in all Cape Hallett core samples was scoured and eroded, indicating that ablation of the ice algal community may have occurred. We believe, due to the similarity between the 2003 and 2004 season, and the consistently low biomasses throughout the sampling period, that high currents caused ablation of sea ice algal biomass from the bottom of the ice, and this reduced the apparent standing stock of sea ice algae in Cape Hallett. Considering the high currents in the region, this may be a persistent phenomenon along the coast of Victoria Land, where the environment for ice algal growth may be very different from that in the McMurdo Sound area.

The primary variables influencing sea ice algal growth are elevated salinity, access to nutrients, and irradiance. Net photosynthesis occurs during spring and summer where snow cover is less than c. $0.3 \mathrm{~m}$ (Grossi et al. 1987, Arrigo et al. 2003). Given the variability in thickness of both snow and ice, the irradiance that penetrates to microbial communities exhibits high variability. While a negative relationship between Chl $a$ accumulation and snow depth might generally be expected, recent findings in the Arctic suggest that productivity may be enhanced by some degree of snow cover (Mundy et al. 2005). These authors observed maximum biomass under intermediate snow cover, while a decline in algal biomass and sloughing of cells under thin snow cover was correlated with desalination of the aboveice cover. Deep snow will modify shade acclimation of algal cells but since drifting snow is a common feature of the Antarctic coastal topography, snow depth may not necessarily give an accurate history of previous light conditions (Garrison \& Buck 1991). The area of ice at Cape Evans with snow cover examined in 1999 was in the lee of the Cape and remained the same thickness during the entire sampling period. Similarly, the snow free area chosen for study had been clear of snow for the month prior to our study and remained clear for its duration. The similarity in species composition and biomass (Table I) between the snow and snow-free areas suggests that both communities were well acclimated to ambient light levels.

\section{Species composition}

Species composition was relatively consistent from year to year at Cape Evans, and taking the two years into account it can be seen that the dominant species were Entomoneis kjellmannii, Nitzschia stellata, Navicula glaciei and Fragilariopsis curta. Nitzschia lecointei and Pleurosigma solinarum were also common. In 1999 the tube dwelling diatom Berkeleya adeliensis increased in abundance in the latter part of the season. This was due to the development of tubes of cells suspended from the bottom of the ice, and they remained because there was little or no current and no platelet ice formed in this location. This is consistent with previous compositions (e.g. Palmisano \& Sullivan 1983, McMinn 1997, McMinn et al. 2000). Entomoneis kjellmannii and $N$. stellata are both usually associated with interstitial ice (McConville \& Wetherbee 1983), while species such as $B$. adeliensis form strand communities, and seem to prefer higher light (snow-free ice) (McMinn 1997). The same suite of species is also present in fast ice in East Antarctica (Watanabe et al. 1990, Archer et al. 1996, RiauxGobin et al. 2003) and in the Ross Sea pack ice (Arrigo et al. 2003, Garrison et al. 2005) although dominant species vary.

At Cape Hallett the dominant species were F. curta and $N$. stellata. Cylindrotheca closterium and $N$. lecointei were common, while the larger celled species, which were dominant at Cape Evans, were almost completely absent. It 
is interesting to note that the surface brine algal community composition was different both taxonomically and in biomass, especially in 2004 when there was a high concentration of the dinoflagellate Polarella glacialis. This taxon was also found in abundance in the surface of sea ice at Terra Nova Bay $\left(76^{\circ} \mathrm{S}\right)$ (Andreoli et al. 2000). Similar observations have been noted by Archer et al. (1996) in fast ice at Davis Station in East Antarctica.

The observed difference in species composition between the two sampling sites reflects different environmental conditions. The strong currents in the Cape Hallett area prevent the formation of the productive brine channels typically found on the underside of fast ice, and may provide unfavourable conditions for the larger ice algal species such as Entomoneis kjellmannii and Berkeleya adeliensis. The latter, forming strands, would naturally be removed by the currents, although this species may not be present in the area as it was not observed in water samples. Entomoneis kjellmannii was found in low numbers in some cores. The prevalence of small-celled species such as F. curta at Cape Hallett has resulted in a bottom-ice algal community that is more similar to pack ice (Garrison et al. 2005, McMinn et al. in press) than to fast ice. Furthermore, the low Chl $a$ levels at Cape Hallett are more typical of pack ice at the same latitude (Arrigo et al. 2003) than of fast ice.

Since the phytoplankton in the water column at Cape Hallett were of a similar species composition to that in the ice above (Table IV), and that they are well mixed through the entire $100 \mathrm{~m}$ profile (Figs $5 \mathrm{c} \& 6 \mathrm{a}$ ), it is likely that the algae in the seawater are enriched from the ablated bottom ice community. Fragilariopsis curta is the most abundant diatom in the western Ross Sea and Terra Nova Bay (Nelson \& Smith 1986, Andreoli et al. 1995, Nuccio et al. 1999, Fonda Umani 2005), giving rise to some of the most prominent ice edge blooms in Antarctica (Knox 1990). Seeding from the ice is highly likely, as observed also in the Weddell Sea (Hegseth \& Quillfeldt 2002). In McMurdo Sound, the spring bloom is composed almost entirely of Phaeocystis antarctica (Knox 1990), thus the ice algal communities in this area do not seem to seed pelagic blooms. One reason for this could be that more of the dominating species are obligate ice algae, and not suitable for pelagic growth. Another possibility is that Phaeocystis is brought into the area from outside (Rivkin \& Voytek 1987), and that this happens before the ice starts to melt. By that time, the Phaeocystis bloom is already dominating. Diatoms are also observed in the pelagic blooms of McMurdo Sound. However, the common species Thalassiosira scotia and Fragilariopsis kerguelensis are mainly pelagic (Scott \& Thomas 2005), although the latter is sometimes found in sea ice (Archer et al. 1996).

\section{Relative contributions of sea ice and seawater communities to total biomass}

Our chlorophyll data from the water column at Cape Hallett (Fig. 6a) and the CTD chlorophyll profiles (Fig. 5c) show that phytoplankton were present through the water column to at least $100 \mathrm{~m}$ and distributed relatively evenly throughout. A CTD cast was made on November 22 (Fig. 5c), and immediately afterward, Chl $a$ concentrations were determined by the extraction method from water bottle samples (Fig. 6a). Assuming that the primary productivity in the benthos below our site and in the water over $100 \mathrm{~m}$ deep was negligible, we estimate that the ice contributed c. $2 \%$ of the total Chl $a$ in the full ice-water column at Cape Hallett on that day. Duplicate measurements on other days gave a similar percentage (data not shown). Given that the current under the ice was fairly constant and strong, and that the CTD profiles show little change in Chl $a$ over the three week period of the study, it is reasonable to assume that this represents the contribution of the ice to the total water column standing crop at this time. This contribution from the ice is unusually low for fast ice, which normally contains approximately $20-30 \%$ of total water column standing crop (Arrigo et al. 1998).

An understanding of the spatial and temporal dynamics of Antarctic sea ice and the associated biotic communities is fundamental to quantifying Southern Ocean productivity and the trophodynamics of the Antarctic coastal ecosystem. Projected warming for polar regions over the 21 st century is likely to reduce the extent and thickness of annual sea ice (Kerr 2006, Velicogna \& Whar 2006), which will alter both the light and salinity regimes to which the microbial community is exposed. These events could modify the significant contribution that the sea ice microbial community makes to Southern Ocean primary production (Arrigo et al. 2003). Large-scale environmental factors including solar and ultraviolet-B radiation, temperature and day length vary with latitude and these variables may play a dominant role in future sea ice productivity, although we know little about how different microbial systems will respond (Ryan et al. 2004). Biodiversity and growth rates of Antarctic marine micro-organisms may serve as valuable markers for environmental monitoring, due to their short generation times and simple cellular structure (Jochem 2000).

Our initial findings show large differences in biomass and community composition within fast ice in two locations separated by five degrees of latitude along the coast of Victoria Land. While these sites were selected to be of similar ice thickness and proximity to shore, and were collected at similar (though not the same) times of the year, the pattern of change was opposite to that expected for a north-south gradient. There were significant differences in the physicochemical characteristics of each site, and primary among these were differences in local water 
currents. It is therefore important to stress that local conditions play a crucial role in determining production. In future studies along the Victoria Land coastline, we will attempt to quantify the extent to which ice-driven dynamics control the structure and function of the sea ice ecosystem and design biophysical process models describing the productivity of the microbial populations at each site.

\section{Acknowledgements}

We thank Antarctica NZ for logistic support and in particular the LGP team, Shulamit Gordon, Rachel Brown and Gus McAlister for their efficient construction and management of the field camp at Cape Hallett. Thanks too to the Scott Base staff, for their help in preparation for the field. Ken Ryan acknowledges the support of the Foundation of Research Science and Technology contract no (VICX0219). Else Hegseth's contribution was supported by The Norwegian College of Fishery Science, University of Tromsø. Andrew McMinn acknowledges the financial and logistical support of an Australian Antarctic Science grant and financial support from the Australian Research Council. Peter Ralph thanks the Australian Research Council grant number DP0344067. Joe Buchanan performed some of the microscopy work, and Ulf Normann prepared the CTD figures. We thank the reviewers for their helpful comments.

\section{References}

Andreoli, C., Tolomio, C., Moro, I., Radice, M., Moschin, E. \& Bellato, S. 1995. Diatoms and dinoflagellates in Terra Nova Bay (Ross Sea-Antarctica) during austral summer 1990. Polar Biology, 15, $465-475$

Andreoli, C., Moro, I., LaRocca, N., Dalle Valle, L., Masiero, L., Rascio, N. \& Dalla Vecchia, F. 2000. Ecological, physiological and biomolecular surveys on microalgae from Ross Sea (Antarctica). Italian Journal of Zoology, 67, 147-156.

Archer, S.D., Leakey, R.J.G., Burkill, P.H., Sleigh, M.A. \& Appleby, C.J. 1996. Microbial ecology of sea ice at a coastal Antarctic site: community composition, biomass and temporal change. Marine Ecology Progress Series, 135, 179-195.

Arrigo, K.R. \& Sullivan, C.W. 1992. The influence of salinity and temperature co-variation on the photophysiological characteristics of Antarctic sea ice microalgae. Journal of Phycology, 28, 746-756.

Arrigo, K.R., Robinson, D.H. \& Sullivan, C.W. 1993. A high resolution study of the platelet ice ecosystem in McMurdo Sound, Antarctica: photosynthetic and bio-optical characteristics of a dense microalgal bloom. Marine Ecology Progress Series, 98, 173-185.

Arrigo, K.R., Worthen, D., Schnell, A. \& Lizotte, M.P. 1998. Primary production in Southern Ocean waters. Journal of Geophysical Research, 103, 15 587-15 600 .

Arrigo, K.R., Robinson, D.H., Dunbar, R.B., Leventer, A.R. \& Lizotte, M.P. 2003. Physical control of chlorophyll $a$, POC, and TPN distributions in the pack ice of the Ross Sea, Antarctica. Journal of Geophysical Research, 108, doi: 10.1029/2001JC001138.

ARrigo, K.R. \& Thomas, D.N. 2004. Large scale importance of sea ice biology in the Southern Ocean. Antarctic Science, 16, 471-486.
BARRY, J.P. \& DAYTON, P.K. 1988. Current patterns in McMurdo Sound, Antarctica and their relationship to local biotic communities. Polar Biology, 8, 367-376.

Buck, K.R., Bolt, P.A., Bentham, W.N. \& Garrison, D.L. 1992. A dinoflagellate cyst from Antarctic sea ice. Journal of Phycology, 28, $15-18$.

Evans, C.A., O'Reilly, J.E. \& Thomas, J.P. 1987. A handbook for the measurement of chlorophyll $a$ and primary production. College Station, TX: Texas A\&M University, 114 pp.

FAlCONER, T. \& PYNe, A. 2000. Sea ice analysis for proposed hydrographic survey - Cape Hallett, Cape Adare and Possession Islands. (LINZ project number 1017). Antarctic Research Centre, School of Earth Sciences, Victoria University of Wellington.

Fonda Umani, S., Monti, M., Bergamasco, A., Cabrini, M., De Vittor, C., Burba, N. \& Del Negro, P. 2005. Plankton community structure and dynamics versus physical structure from Terra Nova Bay to Ross Ice Shelf (Antarctica). Journal of Marine Systems, 55, 31-46.

Garrison, D.L. 1991. Antarctic sea ice biota. American Zoologist, 31, $17-33$.

Garrison, D.L. \& BucK, K.R. 1991. Surface-layer sea ice assemblages in Antarctic pack ice during the austral spring: environmental conditions, primary productivity and community structure. Marine Ecology Progress Series, 75, 161-172.

Garrison, D.L., Gibson, A., Coale, S.L., Gowing, M.M., Okolodkov, Y.B., Fritsen, C.H. \& JefFeries, M.O. 2005. Sea-ice microbial communities in the Ross Sea: autumn and summer biota. Marine Ecology Progress Series, 300, 39-52.

GiLmore, A.E. 1963. Hydrological heat and mass transport across the boundary of the ice shelf in McMurdo Sound, Antarctica. New Zealand Journal of Geology and Geophysics, 6, 402-422.

Gordon, S. 2003. LGP Initial Environmental Evaluation. Christchurch: Antarctica New Zealand, 35 pp. [Unpublished].

Grossi, S.M. \& Sullivan, C.W. 1985. Sea ice microbial communities. V. The vertical zonation of diatoms in an Antarctic fast ice community. Journal of Phycology, 21, 401-409.

Grossi, S.M., Kottmeier, S.T., Moe, R.L., Taylor, G.T. \& Sullivan, C.W. 1987. Sea ice microbial communities. VI. Growth and primary production in bottom ice under graded snow cover. Marine Ecology Progress Series, 35, 153-164.

Heath, R.A. 1977. Circulation across the ice shelf edge in McMurdo Sound, Antarctica. In DunBar, M.J., ed. Polar oceans. Calgary: Arctic Research Institute, 129-149.

Hegseth, E.N. \& Von Quillfeldt, C.H. 2002. Low phytoplankton biomass and ice algal blooms in the Weddell Sea during the ice-filled summer of 1997. Antarctic Science, 14, 231-243.

Howard-Williams, C., Peterson, D., Lyons, W.B., Cattaneo-Vietti, R. \& GoRDON, S. 2006. Measuring ecosystem response in a rapidly changing environment: the Latitudinal Gradient Project. Antarctic Science, 18, 465-471.

JoCHEM, F.J. 2000. Probing the physiological state of phytoplankton at the single-cell level. Scientia Marina, 64, 183-195.

Johnson, E.S. \& VAN WoERT, M.L. 2006. Tidal currents of the Ross Sea and their time stability. Antarctic Science, 18, 141-154.

KerR, R.A. 2006. A worrying trend of less ice, higher seas. Science, 311, 1698-1701.

KnOX, G.A. 1990. Primary production and consumption in McMurdo Sound, Antarctica. In Kerry, K.R. \& Hempel, G., eds. Antarctic ecosystems: ecological change and conservation. Berlin: Springer, $115-128$

Legendre, L., Ackley, S.F., Dieckmann, G.S., Gulliksen, B., Horner, R., Hoshiai, T., Melnikov, I.A., Reeburgh, W.S., Spindler, M. \& Sullivan, C.W. 1992. Ecology of sea ice biota. 2. Global significance. Polar Biology, 12, 429-444. 
McConville, M.J. \& Weatherbee, R. 1983. The bottom ice microalgal community from annual ice in the inshore waters of East Antarctica. Journal of Phycology, 19, 431-439.

McMinn, A. 1997. Species succession in fast ice algal communities: a response to UV-B radiation? Korean Journal of Polar Research, 8, $47-52$.

McMinn, A. \& Ashworth, C. 1998. The use of oxygen microelectrodes to determine the net production by an Antarctic sea ice algal community. Antarctic Science, 10, 39-44.

MCMinn, A., Ashworth, C. \& RYAn, K.G. 1999a. Growth and productivity of Antarctic sea ice algae under PAR and UV irradiances. Botanica Marina, 42, 401-407.

McMinn, A., Skerratt, J., Trull, T., Ashworth, C. \& Lizotte, M. 1999 b. Nutrient stress gradient in the bottom $5 \mathrm{~cm}$ of fast ice, McMurdo Sound, Antarctica. Polar Biology, 21, 220-227.

McMinn, A., Ashworth, C. \& Ryan, K.G. 2000. In situ net primary productivity of an Antarctic fast ice bottom algal community. Aquatic Microbial Ecology, 21, 177-185.

McMinn, A., Ryan, K.G., RalPh, P. \& Pankowski, A. In press. Spring sea ice photosynthesis, primary productivity and biomass distribution in eastern Antarctica, 2002-2004. Marine Biology.

Mock, T. \& THOMAs, D.N. 2005. Recent advances in sea-ice microbiology. Environmental Microbiology, 7, 605-619.

Mundy, C.J., BARBER, D.G. \& Michel, C. 2005. Variability of snow and ice thermal, physical and optical properties pertinent to sea ice algae biomass during spring. Journal of Marine Systems, 58, 107-120.

Nelson, D.M. \& Smith, W.O. 1986. Phytoplankton bloom dynamics of the western Ross Sea ice edge - II. Mesoscale cycling of nitrogen and silicon. Deep-Sea Research, 33, 1389-1412.

Nuccio, C., Innamorati, M., Lazzara, L., Mori, G. \& Massii, L. 1999. Spatial and temporal distribution of phytoplankton assemblages in the Ross Sea. In Faranda, F.M., Guglielmo, L. \& Ianora, A., eds. Ross Sea ecology. Berlin: Springer, 231-245.

Palmisano, A.C. \& Sullivan, C.W. 1983. Sea ice microbial communities (SIMCO) 1. Distribution, abundance and primary production of ice microalgae in McMurdo Sound, Antarctica in 1980. Polar Biology, 2, 171-177.

Palmisano, A.C. \& GARRISON, D.L. 1993. Microorganisms in Antarctic sea ice. In Friedman, E.I., ed. Antarctic microbiology. New York: WileyLiss, 167-218.

Palmisano, A.C., Kottmeier, S., Moe, R. \& Sullivan, C.W. 1985. Sea ice microbial communities. IV. The effect of light perturbation on microalgae at the seawater interface in McMurdo Sound, Antarctica. Marine Ecology Progress Series, 21, 37-45.

Peterson, D. \& Howard-Williams, C., eds. 2001. The Latitudinal Gradient Project. Christchurch: Antarctica New Zealand, Special Publication, $46 \mathrm{pp}$.
Picco, P., Beergamasco, A., Demimicheli, L., Manzella, G., Meloni, R. \& PASCHINI, E. 1999. Large-scale circulation features in the Central and Western Ross Sea (Antarctica). In Faranda, F., Guglielmo, L. \& IANORA, A., eds. Ross Sea ecology. Berlin: Springer, 95-105.

Riaux-Gobin, C., Treguer, P., Poulin, M. \& Vetion, G. 2003. Nutrients, algal biomass and communities in land-fast ice and seawater off Adélie Land (Antarctica). Antarctic Science, 12, 160-171.

Rivkin, R.B. \& VoYteK, M.A. 1987. Photoadaptations of photosynthesis and carbon metabolism by phytoplankton from McMurdo Sound, Antarctica. 1. Species-specific and community responses to reduced irradiances. Limnology and Oceanography, 32, 249-259.

RyAN, K.G. \& BeAgLehole, D. 1994. Ultraviolet radiation and bottom-ice algae: Laboratory and field studies from McMurdo Sound, Antarctica. Antarctic Research Series, 62, 229-242.

Ryan, K.G., McMinn, A., Mitchell, K.A. \& Trennery, L. 2002. Mycosporine like amino acids in Antarctic sea ice algae, and their response to UVB radiation. Zeitschrift fur Naturforshhung, 57, 461-477.

RYAN, K.G., RalPh, P. \& MCMinn, A. 2004. Acclimation of Antarctic bottom-ice algal communities to lowered salinities during melting. Polar Biology, 27, 679-686.

Scott, F.J. \& Thomas, D.P. 2005. Diatoms. In Scott, F.J. \& Marchant, H.J., eds. Antarctic marine protists. Canberra: Australian Biological Resources Study \& Hobart: Australian Antarctic Division, 13-201.

Stoecker, D.K., BuCK, K.R. \& PutT, M. 1991. Photosynthetic dinoflagellates and their cyst characteristics of the land fast ice. Antarctic Journal of the United States, 26, 143-144.

Sullivan, C.W., Palmissano, A.C., Kottmeier, S. \& Moe, R. 1982. Development of the sea ice microbial community in McMurdo Sound. Antarctic Journal of the United States, 17, 155-157

Sullivan, C.W., Palmisano, A.C., Kottmeier, S., McGrath Grossi, S. \& MoE, R. 1985. The influence of light on growth and development of the sea-ice microbial community of McMurdo Sound. In SiEgFried, W.R., Condy, P.R. \& Laws, R.M., eds. Antarctic nutrient cycles and food webs. Berlin: Springer, 78-83.

Thomas, D.N. \& Dieckmann, G.S. 2002. Antarctic sea ice - a habitat for extremophiles. Science, 295, 641-644.

Thomas, D.N., Kattner, G., Engbrodt, R., Giannelli, V., Kennedy, H., HaAs, C. \& Dieckmann, G.S. 2001. Dissolved organic matter in Antarctic sea ice. Annals of Glaciology, 33, 297-302.

Trenerry, L.J., McMinn, A. \& RyAn, K.G. 2002. In situ oxygen microelectrode measurements of bottom-ice algal production in McMurdo Sound, Antarctca. Polar Biology, 25, 72-80.

VelicognA, I. \& WAHR, J. 2006. Measurement of time-variable gravity show mass loss in Antarctica. Science, 311, 1754-1756.

Watanabe, K., SaOH, H. \& Hoshiai, T. 1990. Seasonal variation in ice algal assamblages in the fast ice near Syowa Station in 1983/84. In Kerry, K.R. \& Hempel, G., eds. Antarctic ecosystems: ecological change and conservation. Berlin: Springer, 136-142. 